\title{
Evaluation of Small Tree and Shrub Plantings on Reclaimed Surface Mines in West Virginia
}

\author{
Alexis Monteleone
}

Follow this and additional works at: https://researchrepository.wvu.edu/etd

\section{Recommended Citation}

Monteleone, Alexis, "Evaluation of Small Tree and Shrub Plantings on Reclaimed Surface Mines in West Virginia" (2017). Graduate Theses, Dissertations, and Problem Reports. 6250.

https://researchrepository.wvu.edu/etd/6250

This Thesis is protected by copyright and/or related rights. It has been brought to you by the The Research Repository @ WVU with permission from the rights-holder(s). You are free to use this Thesis in any way that is permitted by the copyright and related rights legislation that applies to your use. For other uses you must obtain permission from the rights-holder(s) directly, unless additional rights are indicated by a Creative Commons license in the record and/ or on the work itself. This Thesis has been accepted for inclusion in WVU Graduate Theses, Dissertations, and Problem Reports collection by an authorized administrator of The Research Repository @ WVU. For more information, please contact researchrepository@mail.wvu.edu. 


\title{
Evaluation of Small Tree and Shrub Plantings on Reclaimed Surface Mines in West Virginia
}

\author{
Alexis Monteleone \\ Thesis submitted to the Davis College of Agriculture, Natural Resources, and \\ Design at \\ West Virginia University \\ in partial fulfillment of the requirements for the degree of \\ Master of Science in Agronomy \\ Jeffrey Skousen, Ph.D., Chair \\ Jamie Schuler, Ph.D. \\ Louis M. McDonald, Ph.D. \\ Department of Plant and Soil Sciences \\ Morgantown, WV \\ 2017
}

Keywords: Reclamation, forestry, shrubs, reforestation

Copyright 2017 Alexis Monteleone 


\section{Abstract \\ Evaluation of Small Tree and Shrub Plantings on Reclaimed Surface Mines in West Virginia \\ Alexis Monteleone}

Hundreds of acres of mined land are reclaimed annually in West Virginia (WV) and are planted with hardwood tree species. Forestry and wildlife post-mining land uses require the planting of specific tree species designated by the individual mine permit and planting plan, which generally includes planting of commercially-valuable hardwood species. Establishment and growth of fruit- and nut-producing small tree and native shrub species has not been studied for reforestation plantings on surface mines. Though these species are not generally planted as part of forestry reclamation, they are commonly found in forest ecosystems of WV and are often an important component, contributing to both structural and floral species diversity. Survival and growth of 20 species of mast- and fruit-producing shrubs and small trees were evaluated to better understand their suitability for reclamation plantings. Seedlings were planted in graded overburden material during 2008 and 2010 on four reclaimed surface coal mines in WV. The selected sites were reclaimed using conventional methods. The experiment was a completely randomized block design with four blocks per site, two east-facing and two west-facing. Each block was comprised of 20 monoculture species plots, and within each plot 25 individuals were planted on $2.4 \mathrm{~m} \times 2.4 \mathrm{~m}$ spacing. Initial data on survival and growth of these species was collected in 2008 and 2010 a growing season after establishment. Survival and growth of these species were measured again in 2015 and 2016 to determine individual species performance over time.

In general, 18 of the 20 species included in this study were successful in establishing and growing on the reclaimed surface mine sites in West Virginia. The exceptions were pawpaw (Asimina triloba L.) on the sites planted in 2008 and blueberry (Vaccinium corymbosum L.) on the sites planted in 2010. The best performing species overall were black chokeberry (Aronia melanocarpa Michx.) at 56\% survival, black cherry (Prunus serotina Ehrh.) at 55\%, Washington hawthorn (Crataegus phaenopyrum L. f.) at 54\%, nannyberry (Viburnum lentago L.) at 52\%, and hazelnut (Corylus avellana L.) at 50\%. The two species that experienced the highest mortality were flowering dogwood (Cornus florida L.) at 10\% and pawpaw at 9\%. Across all species, Elk Run showed the highest survival percentage at 51\%, Fola and ICG were between 40 and $45 \%$, while Hobet had the lowest at $25 \%$. Although survival and some height measurements were found to be greater on west-facing aspects when compared with east-facing aspects in this study, the results were not strongly correlated and skewed by a few species that performed particularly well on west-facing aspects at one site. The effect of aspect for the majority of species in this study and at most sites was not significant at the individual species level. Soil properties varied widely among sites with $\mathrm{pH}$ ranging from 3.4 at Fola to 7.5 at ICG, fines ranged from 58\% at ICG to $82 \%$ at Hobet, and elemental concentrations showed large variability. When compared to the growth rates exhibited by these species in horticultural, forestry, or agricultural settings, the growth rates were considerably less in this project with these mine soil conditions.

In order to correlate average heights observed with soil properties in the mine soils, stepwise regression, principle component analysis and principle component regression were used. The analysis showed potassium, phosphorus, and aluminum as being the most strongly correlated ( $\mathrm{R}^{2}$ of 0.20$)$ with plant height when all species' average heights at all four sites were considered. Since the mine soil properties were so different at each site, separate regressions 
were performed. Copper was the most significant soil property for height at Elk Run and ICG, no soil properties were significant at Fola, and EC and Na were important at Hobet.

The results of this study demonstrated that several small tree and shrub species have potential for planting on surface mines in West Virginia. Species like black chokeberry, black cherry, Washington hawthorn, and nannyberry, which had greater than $50 \%$ survival after 6 or 8 years, are the most likely candidates. Other species which are adapted to better soil conditions did not perform well and should not be considered for plantings. 


\section{Acknowledgments}

The author thanks Rick Williams, Jon Pomp, and Michael French of Williams Forestry. The idea for this project was developed by Rick Williams, and he and his workers located the sites and transplanted the more than 10,000 seedlings in this study. Jon Pomp and Michael French were responsible with others for monitoring the survival and growth during the first two years following planting. These early data were made available to Dr. Jeff Skousen, which allowed a comparison between first year survival and growth data vs data collected in 2015 and 2016 . I also thank Keith O’Dell and Bill Young of ICG; Kermit Fincham, Scott Perdue, and Cody Cooper of Elk Run; Dave Bays of Fola; Kenny Daniel of Hobet; and Mark McCoy of Nicholas for help in locating the plots and allowing access. I cannot thank Ida Holaskaova enough for help with statistical analysis, our countless meetings, great conversations, and many chocolates.

I would like to thank Dr. Jeff Skousen for this opportunity. I don't know what he saw in me in his undergraduate class that made him remember me, but I am eternally thankful. A project like this is something that I've always wanted to be a part of, and I learned so much in these past two years - I didn't even know I didn't know. Dr. Skousen taught me the value of hard work through working hard on this project. I can never thank him enough for all the time and help with this project over the last two years. Dr. Skousen was also there for me through illness and through personal issues, and I can never thank him enough for his time spent on me.

My other committee members, Dr. Jamie Schuler and Dr. Louis McDonald also deserve recognition. Thank you to Dr. Schuler for allowing a soils student into your silviculture class, for answering some pretty dumb forestry questions, and for never admitting that I should know a lot more about trees. Dr. McDonald, thank you so much for everything. You helped to create my soil sampling design, helped me through many laboratory analysis decisions, and were very patient with me - a field scientist who has no business being in a lab.

"I can no other answer make but thanks, and thanks, and ever thanks..." - William Shakespeare 


\section{Table of Contents}

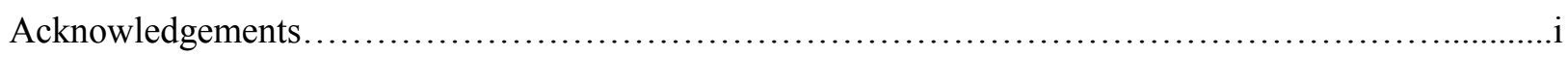

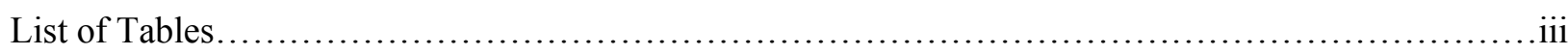

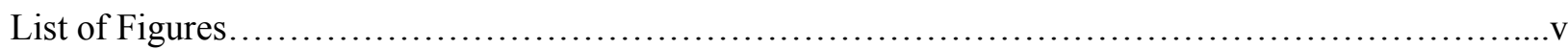

Introduction........................................................................................

Purpose and Objectives...........................................................

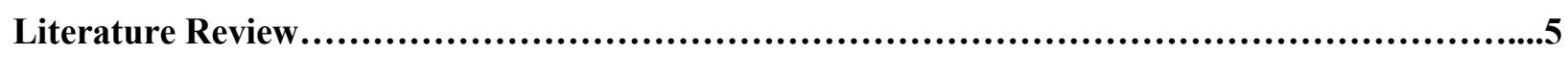

Part 1: Reclamation............................................................

Part 2: Silvics of Species Included in the Study ......................................

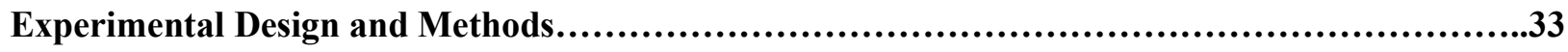

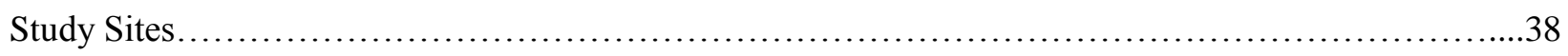

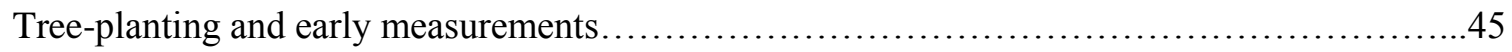

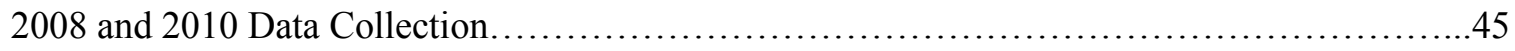

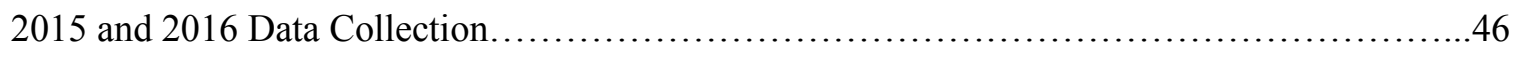

Statistical Analysis........................................................... 47

Results..............................................................................................48

Soil Properties................................................................48

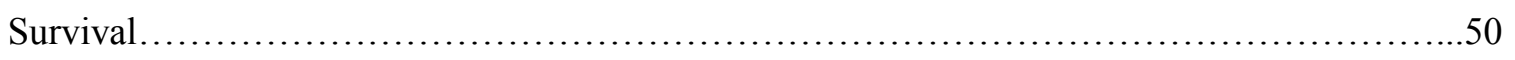

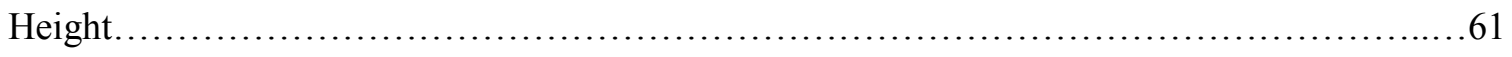

Discussion.........................................................................................90

Survival...................................................................90

Height $\ldots \ldots \ldots \ldots \ldots \ldots \ldots \ldots \ldots \ldots \ldots \ldots \ldots \ldots \ldots \ldots \ldots \ldots \ldots \ldots \ldots \ldots \ldots \ldots \ldots \ldots \ldots . \ldots 3$

Correlating soil properties to plant height....................................94

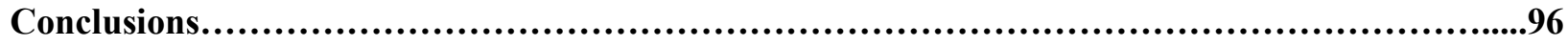

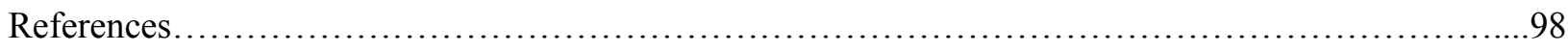

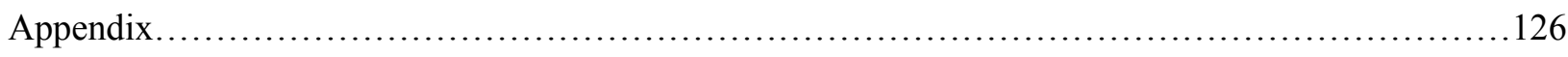




\section{List of Tables}

Table 1. Summary table of important silvics for establishment of each species..............9-10

Table 2. List of tree and shrub species used in trials. Growth forms were determined using the

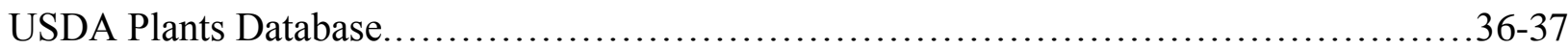

Table 3. Average values for site parameters for soils at each site measured in $2015 \ldots \ldots \ldots \ldots . . .48$

Table 4. Statistics of year by survival percentage..................................49-50

Table 5. Species survival by site. The Chi-square probability of significant difference between

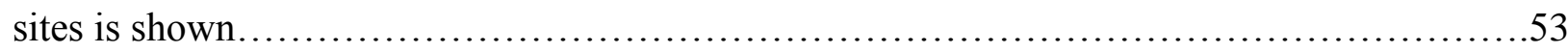

Table 6. The nonzero correlation of age and survival of species on the older sites (Elk Run and Hobet) planted in 2008. Significance determined by p-value $<0.05$. P-values derived from the repeated frequency analysis using the ridit scores of the Manel_Haenszel procedure. The nonzero correlation value was used because of the repeated measures.............................57

Table 7. The nonzero correlation of age and survival of species on the older sites (Elk Run and Hobet) planted in 2010. Significance determined by p-value <0.05. P-values derived from the repeated frequency analysis using the ridit scores of the Manel_Haenszel procedure. The nonzero correlation value was used because of the repeated measures...............................59

Table 8. Average height of each species after one growing season and after 8 growing seasons on the sites planted in 2008, Elk Run and Hobet, using age as a repeated measure. The TukeyKramer adjustment was made to the calculated p-values in order to make the test more conservative and control type I errors from occurring................................ 70

Table 9. Average height of each species after the first growing season and after 6 growing seasons on sites planted in 2010, Fola and ICG, using age as a repeated measure. The TukeyKramer adjustment was made to the calculated p-values in order to make the test more conservative and control type I errors from occurring.

Table 10. ANOVA results testing the effect of site on species height and the effect of the site*age interaction on the sites planted in 2008, Elk Run and Hobet, using age as a repeated measure. The Tukey-Kramer adjustment was made to the calculated p-values in order to make the test more conservative and control type I errors from occurring $\ldots \ldots \ldots \ldots \ldots \ldots \ldots \ldots \ldots \ldots . \ldots \ldots$

Table 11. ANOVA results testing the effect of site on species height and the effect of the site*age interaction on the sites planted in 2010, Elk Run and ICG, using age as a repeated measure. The Tukey-Kramer adjustment was made to the calculated p-values in order to make the test more conservative and control type I errors from occurring $\ldots \ldots \ldots \ldots \ldots \ldots \ldots \ldots \ldots \ldots \ldots$

Table 12. Results of stepwise regression on the sites planted in 2008 (Elk Run and Hobet) showing significant correlations between site parameters and average height by species. $(\mathrm{p} \leq$ $0.05=$ significant). Only 11 species showed significant correlations. .76-77 
Table 13. Results of stepwise regression on the sites planted in 2010 (ICG and Fola) showing significant correlations between site parameters and average height by species. $(\mathrm{p} \leq 0.05=$ significant). Only eight species showed significant correlations............................77

Table 14. Results of PCR of height at all sites in study. The $\mathrm{R}^{2}$ value of 0.15 was obtained..78-79 Table 15. Results of PCR of all significant soil properties in PC 1 and 2 on average height for all sites. The $\mathrm{R}^{2}$ value of 0.20 was obtained. Only three properties were significant................79 Table 16. Results of PCR of average height at Elk Run. The $\mathrm{R}^{2}$ value was $0.28 \ldots \ldots \ldots \ldots \ldots . . . .81$ Table 17. Results of PCR of the soil properties from the significant PC2 (Table 8) on average height at Elk Run. Only copper was found to be significant..............................82

Table 18. Results of PCR of height at Hobet. A $\mathrm{R}^{2}$ value of 0.22 was found...................83

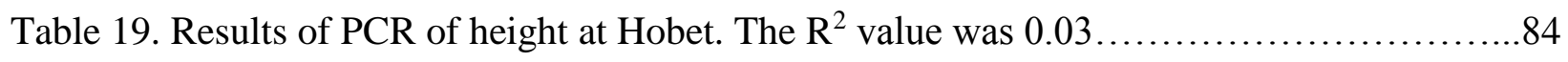

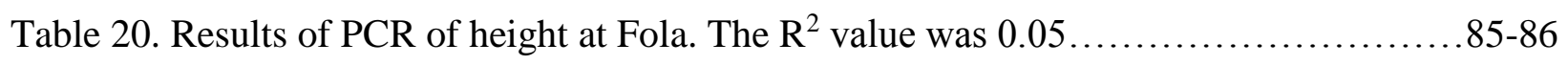

Table 21. Results of PCR of height at ICG. The $\mathrm{R}^{2}$ value was $0.34 \ldots \ldots \ldots \ldots \ldots \ldots \ldots \ldots \ldots \ldots . . . \ldots \ldots$

Table 22. Results of PCR of height at ICG. A R ${ }^{2}$ value of 0.45 was found.....................87 


\section{List of Figures}

Figure 1. The randomized complete block design used at ICG. Numbers within plots represent different tree and shrub species (Table 2). Twenty-five individuals of each species were planted in each plot on $2.4 \times 2.4 \mathrm{~m}$ spacings.

Figure 2. The randomized complete block design at Elk Run. Numbers within plots represent different tree and shrub species (Table 2). Twenty-five individuals of each species were planted in each plot on $2.4 \times 2.4 \mathrm{~m}$ spacings.

Figure 3. The randomized complete block design used at Hobet. Numbers within plots represent different tree and shrub species (Table 2). Twenty-five individuals of each species were planted in each plot on $2.4 \times 2.4 \mathrm{~m}$ spacings.

Figure 4. Figure 4. The randomized complete block design at Fola. Numbers within plots represent different tree and shrub species (Table 2). Twenty-five individuals of each species were planted in each plot on $2.4 \times 2.4 \mathrm{~m}$ spacings

Figure 5. The Appalachian Plateau physiographic region in Boone County of southwestern West Virginia where the Hobet and Elk Run Mine are located. .38

Figure 6. Satellite image of research block locations on Elk Run Mine, Boone County, WV in 2008.

Figure 7. Satellite image of research block locations on Hobet Mine, Boone County, WV in 2008 .

Figure 8. The Appalachian Plateau physiographic region in Clay, Nicholas, and Webster Counties of West Virginia where the Fola and ICG Mine are located. ....

Figure 9. Satellite image of research block locations on ICG Mine, Webster and Nicholas County, WV in 2010

Figure 10. Satellite image of research block locations on Fola Mine, Clay County, WV in 2010 .

Figure 11A. Average survival percentages of seven tree species (A-E) by site in 2016 with error

bars. Significant differences were found $(\mathrm{p}<0.0001)$

Figure 11B. Average survival percentages of seven tree species (F-W) by site in 2016 with error bars. Significant differences were found $(\mathrm{p}<0.0001)$..

Figure 11C. Average survival percentages of shrub species by site in 2016 with error bars.

Significant differences were found $(\mathrm{p}<0.0001)$.

Figure 12A. Survival percentages in 2016 of seven tree species (A-E) by aspect with error bars and Chi-square p-values shown. .54

Figure 12B. Survival percentages in 2016 of seven tree species (F-W) by aspect with error bars 
$(\mathrm{p}<0.0001)$.

Figure 12C. Survival percentages in 2016 of shrub species by aspect with error bars (p

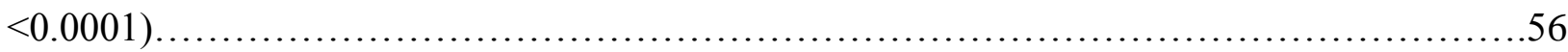

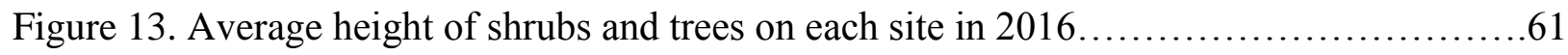

Figure 14A. Average height of seven trees (A-E) on all four sites in $2016 \ldots \ldots \ldots \ldots \ldots \ldots \ldots \ldots . \ldots 62$

Figure 14B. Average height of seven trees (F-W) on four sites in 2016 .....................63

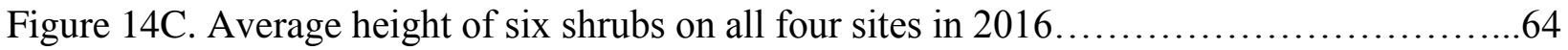

Figure 15. Average height in 2016 for shrubs and trees between the east- and west-facing aspects

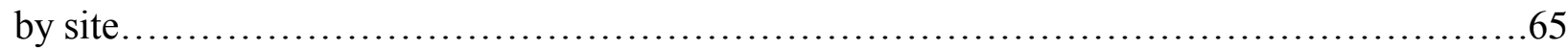

Figure 16A. Average height of selected tree species (A-E) in 2016 at all sites between the east-

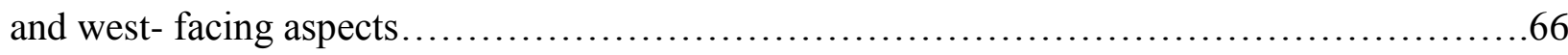

Figure 16B. Average height of selected tree species (F-W) in 2016 at all sites between the east-

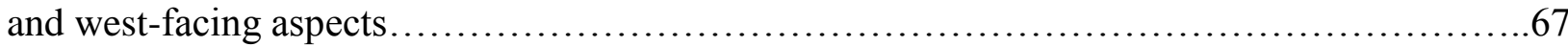

Figure 16C. Average height of shrubs in 2016 at all sites between the east- and west-facing

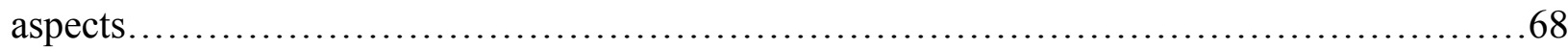

Figure 17. Average height of different growth forms separated by site (Elk Run and Hobet) after

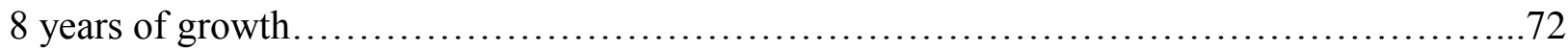

Figure 18. Average height of different growth forms separated by site (Fola and ICG) after 6

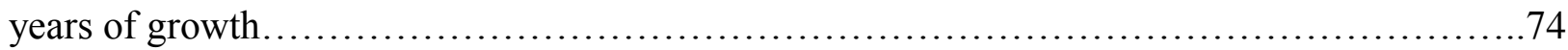

Figure 19. Principle components and correlation depictions on all sites......................78

Figure 20. Biplot showing results of the PCA of soil conditions at Elk Run on average height

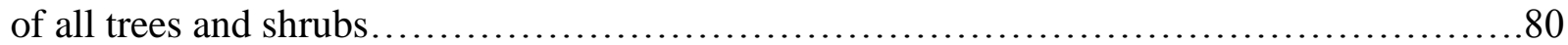

Figure 21. Leverage plot of the effect of $\mathrm{Cu}$ on average height at Elk Run....................82

Figure 22. Biplot showing results of the PCA of soil conditions at Hobet on height..............83

Figure 23. Biplot showing results of the PCA of soil conditions at Fola on height...............85

Figure 24. Biplot showing results of the PCA of soil conditions at ICG on height................86

Figure 25. Leverage plot of the effect of $\mathrm{Cu}$ on average height at ICG..................... 88 


\section{Introduction}

The Appalachian region has over 100 minable coal seams (Bise, 2013), and because of the abundance of coal, the region has had a long history with coal mining. The coal mining industry in the region has been a dynamic one. During the early 1900s, coal mining was primarily by underground mining methods, a change to surface mining happened from 1950 to 2000, and is now shifting again to underground mining. Just as the coal extraction process has changed over time, so has the idea of reclamation. Early reclamation efforts only reshaped the land with little or no emphasis on revegetation of the impacted area. However, with the passage of strict environmental laws, today the focus is on restoring the site back to its original productivity or something better.

Historically, more coal was harvested using underground or shallow surface mining methods. Due to smaller equipment size, particularly for surface mines, technology restricted surface mining to shallow coal seams (Gorman et al, 2001). Reclamation was not a federal requirement, but some states, like West Virginia, enacted legislation in 1939 and the early 1940s (Bowling et al., 1987; Plass, 2000). Enforcement of this legislation was not carried out well and as a result large areas of unreclaimed land were left after mining. This early reclamation focused mainly on reshaping the land and consisted of placing the overburden materials back into the excavated area and smoothing, grading, and compacting the mined area. If anything was planted, it was tree species like black locust (Robinia pseudoacaia) and pine (Pinus spp.) species (Vogel et al., 1981).

Tree growth on reclaimed mine sites has been studied since the 1930s due to interest in trying to re-establish the diverse eastern deciduous Appalachian forest ecosystem on disturbed sites (Zipper, 2011). This forest ecosystem is regarded as the most diverse non-tropical forest ecosystem in the world, and performs important ecosystem services like controlling water quality and quantity, providing wildlife habitat, sequestering carbon, and producing wood and fibers (Burger, 1999; Zipper, 2011). The state of West Virginia is 78 percent forested and the reclamation of disturbed lands to forest sites is important to maintain ecological stability in our region.

Following World War II came the emergence of machinery capable of extending surface mining to deeper depths and across larger landscape areas. Using this new machinery, the 
technology of surface mining developed and coal seams previously too deep or thin to access were now mineable. As more area of land became disturbed, public concern over the disturbed area heightened. As a result, the Surface Mining Reclamation and Control Act of 1977 (SMCRA) was passed and gave federal-to-state oversight for active mines for reclamation and abandoned mine land reclamation (Skousen and Zipper, 2014). SMCRA required that coal mine operators submit a permit, which served as a contract between them and the regulatory authority. This permit outlined all practices that were to be carried out on the mine and it included plans for land use of the postmining area. This designation of a post-mining land use served as a reclamation goal for the mine operator, and different post-mining land uses required different reclamation practices.

The goals outlined in SMCRA were to minimize the adverse effects of coal mining on disturbed land including water quality and quantity, sediment quality and quantity, and vegetative cover (Burger, 1999). Reductions in pollution and runoff have been two goals of reclamation throughout its history, but the methods used to achieve reductions has drastically changed over time as knowledge has increased. After the passage of SMCRA, between the late 1980s and 1990s, mine operators were encouraged to excessively grade and smooth the overburden material and to establish a fast growing herbaceous cover (Torbert and Burger, 2000). Trees were rarely planted because it was easier to achieve bond release criteria using the pasture/hayland post-mining land use. Trees that may have been planted during this time period did not survive or grow well because grading of the overburden created a compacted rooting medium impenetrable by plant roots and the aggressive herbaceous cover competed with woody growth. Further, the grasslands created were composed of highly aggressive agricultural forage species and were not generally managed or harvested for hay or feed, and therefore remained largely as a monoculture restricting the recruitment and colonization of native species, particularly trees. In this condition, the vegetation community fell into a state of ecological arrest where it was unable to progress past the point of being dominated by fescue grasses, and some invasive shrubs. Since 2005 surface grading has become more restricted, lessening compacted soil surfaces are created. The planting of herbaceous species has also been changed to less-competitive species that are often native in origin and seeded at lower rates.

The Appalachian Regional Reforestation Initiative (ARRI) is a cooperative effort by the states of the Appalachian Region with the United States Department of Interior (USDI), Office of Surface Mining (OSM) to encourage restoration of high quality forests on reclaimed coal mines in the 
eastern USA (Angel et al., 2005; Zipper, 2011). ARRI encourages the use of the Forestry Reclamation Approach (FRA) to create successful reforestation plantings and combat the usual challenges, soil depth and compaction, on reclaimed coal mines. The FRA consists of 5 steps:

1. Create a suitable rooting medium compatible with tree growth at least 4 feet deep and made up of topsoil, weathered sandstone, and/or the best material available

2. Do not compact the growing medium with heavy grading, and instead only loosely grade the topsoil or topsoil substitute established in step 1

3. Use a tree compatible herbaceous cover that will not outcompete woody growth

4. Plant two tree types: early successional species for wildlife and soil stability and commercially valuable crop trees

5. Use proper tree planting techniques

The intent of FRA reclamation is to develop a forest plant community with all the ecological components necessary for maximizing multiple uses of the reclaimed area. It has been developed by consensus of a broad group of academic researchers, industry, and regulatory personnel as the most suitable way to establish commercially-valuable tree species on mined sites and to assure their rapid growth and development. The non-compacted soil or soil substitute is created using the FRA paired with the tree-compatible herbaceous cover provides the opportunity for recruitment and colonization of native and volunteer species from surrounding forests to re-inhabit the site (Zipper et al., 2013; Zipper 2011). Foresters know that initially planting a diversity of tree types will more rapidly introduce species that will enhance the functional and structural diversity of the ecosystem. The non-commercial species that can be planted with the commercially-valuable crop trees in Step 4 are still not clearly defined, and will become more evident with more extensive field studies. These non-commercial species largely belong to the early-successional group, which do not dominate mature forest canopies but instead area a part of stand initiation or cohort reestablishment in forest succession. These early-successional ecosystems are very species-diverse due to the amount of growth resources available post-disturbance that were not readily available pre-disturbance (Swanson, 2010). A diverse plant community enhances the wildlife habitat potential, recreational, aesthetic, and productive value of the reclaimed land. Diversity of plant morphologies increase structural richness and contributes to both horizontal and vertical heterogeneity (Swanson, 2010). 
The overall goal of land reclamation is to return the mining area to a condition equal to or better than the land's original condition before mining (Skousen and Zipper, 2014). One way to do this is to plant trees, to return the land to a forest post-mining land use (MacDonald et al., 2015; Zipper et al., 2011, 2013). Early-successional trees and shrubs are said to be ecological enhancers that provide many benefits to the ecosystem (Alday, 2014). This project will help determine potential species that could be planted during reclamation in order to enhance ecosystem development.

\section{Purpose and Objectives}

Surface mining disturbs thousands of acres throughout Appalachia annually. Many of the acres reclaimed each year have non-commercial or unmanaged forestland, commercial or managed forestland, or fish and wildlife as the designated post-mining land use. Areas having these post-mining land uses always have a tree-planting requirement and must be planted using a mix of commercially available 1-0 and 2-0 bareroot seedlings including shrubs, conifers, and hardwoods. The percentage of land planted with trees and shrubs varies by individual permit requirements.

Mining companies typically enlist employees or local labor to do the tree planting, often with little knowledge of proper seedling handling, planting techniques, and individual species requirements (Angel, 2005). These efforts have mixed results because expertise is missing in the selection of planting stock and planting procedures. More often, professional tree planting contractors are hired to plant the selected tree species in sufficient densities so that responsible entities are able to achieve reclamation goals and eventual bond release. Many times there is permit language that allows professional tree planting contractors to plant species that are best suited to the physical and chemical soil conditions, but other times the permit allows no variance in how or which or where species are to be planted (Torbert and Burger, 2009). Generally, only a list of acceptable species is provided in the permit or through the state agency overseeing the permit. Often only a few species are listed (Angel, 2005). Furthermore, by planting fewer species, one risks a tree planting failure if a pest or pathogen infects one or more of the species.

From an ecological perspective, more species are desired to properly benefit wildlife and to provide insurance against the ever-increasing numbers of threats to our forests (Turner, 1998). Responsible tree planting contractors are aware of these problems and already exceed permit requirements not only in the numbers of species they plant as well as increasing stocking density. However little is known about the performance of certain species, especially ecologically 
important understory shrubs and trees, in mine spoils and so these species are generally avoided. Instead companies rely on a few tree species that are known to perform well even though their benefit to wildlife and other ecosystem services are limited.

The intent of this study is to remedy some of the problems listed above. By increasing the known number of species that exhibit good survival and growth on reclaimed mines, state regulatory agencies and professional tree planters will be able to enhance these lands in a positive manner. Planting a wider diversity of trees will allow these lands to more quickly return to a more natural state with increased biodiversity and ecosystem functions. Plus, these sites will have the ability to undergo forest succession more easily than sites reclaimed with less species or on sites that do not include understory species in their plantings.

The goal of this project was to determine additional woody plant species that are suitable in future reclamation plantings. In order to complete this goal:

1) survival and growth of 20 small trees and shrubs planted in 2008 and 2010 on four reclaimed mined sites were determined;

2) the effect of aspect, east- vs west-facing, on species survival and growth was assessed;

3) site and soil properties at these mine sites were determined and these site and soil properties were correlated with height of the trees and shrubs.

\section{Literature Review}

\section{Part 1: Reclamation}

Mine soils are those soils created during reclamation after surface mining. Once materials, whether salvaged topsoil materials or substitute materials composed of broken rock material, are placed at the surface and are not moved again, they become mine soils subject to the five factors of soil formation. Compared to unmined soils, most mine soils have lower infiltration rates, higher bulk density, less organic matter, weaker aggregation of soil particles, and lower nutrient levels. Mine soils may or may not have A horizons and depends on whether salvaged topsoil materials were placed at the surface. Topsoiled mine soils generally exhibit A-C or AAC-C layering (Haering et al., 2004), because no or little time as passed for the development of 
an E or B horizon. Mine soils often have a high rock fragment content (42-81\%), and the variation is due to differing mining practices (Haering et al., 2004). Mine soils developed from shallow cuts have more weathered material which results in lower rock fragments, a lower $\mathrm{pH}$, and finer texture; however, those developed from deeper cuts with more unweathered material have higher rock fragments, higher pH, and less fines (Emerson et al., 2009; Haering et al., 2004). Reclamation and revegetation are required for restoring ecosystem services and biodiversity in places disturbed by coal mining because of the soil removal process required for coal excavation. Removal of the soil material eliminates the seed bank and can expose toxic substrata, which impede plant growth (Chazdon, 2008).

Topsoil substitutes are often used in the Appalachian coal-mining region for reclamation due to the scarcity of topsoil on mountainous landscapes. Two types of topsoil substitutes are generally available and include brown sandstone and gray sandstone materials. Mixtures of these materials are also used as topsoil substitutes. The difference between the two materials is the degree to which they are weathered: gray sandstone is considered to be unweathered and brown sandstone is more weathered. This weathering status has an effect on their physical and chemical properties. It is thought that brown sandstone has less extractable nutrients than gray sandstone due to the higher degree of weathering, the opposite has been found to be true (Emerson and Skousen, 2009). The different degree of weathering also creates a difference in the particle sizes of the topsoil substitutes, with brown sandstone having a greater proportion of smaller particles than gray sandstone. Brown sandstone has a higher electric conductivity than gray sandstone, and this property is related to texture (Burger et al., 2005). Another difference between the two mediums is that gray sandstone has a higher $\mathrm{pH}$ than brown sandstone. This is an important difference because the $\mathrm{pH}$ has large effects on tree growth and can determine the success of reclamation plantings. Grasses and legumes can do well in gray sandstone material with its high $\mathrm{pH}$, but the high $\mathrm{pH}$ is not favorable for the growth of hardwood species (Wilson-Kokes et al., 2013a).

The Surface Mining Reclamation and Control Act (SMCRA) of 1977 requires that reclamation be concurrent with mining (Skousen and Zipper, 2014). The land must be reclaimed to fit a designated post mining land use. Common reclamation practices between 1977 and today include grading and smoothing of the replaced overburden material and establishing a fast growing herbaceous cover (Burger, 2005). Species included in these herbaceous mixes include 
fescues (Festuca spp.) and clovers (Trifolium spp.). These practices combat erosion and sediment-laden runoff problems. However the grading and smoothing of the overburden material leads to severely compacted surfaces and the heavy ground cover of aggressive herbaceous plants can monopolize the water and nutrient resources in the mine soil. This reclamation procedure created land not conducive for woody plant establishment and growth, and areas reclaimed in this manner experience arrested succession (Groniger et al., 2007; Burger, 2005). Arrested succession is the failure of the established ecosystem to progress and undergo natural succession. Instead, these areas are trapped in a state of succession where they are dominated by aggressive herbaceous cover and invasive species and shrubs like sericea lespedeza (Lespedeza cuneata Dum. Cours.), and autumn olive (Elaeagnus umbellatum Thunb.). Woody plants require a deep, uncompacted rooting medium for good growth and a compatible, less-aggressive herbaceous cover. Examples of more compatible herbaceous covers include orchardgrass (Dactylis glomerata L.), redtop (Agrostis gigantea Roth.), birdsfoot trefoil (Lotus corniculatus L.) and crown vetch (Securigera varia L.) (Franklin et al., 2012).

The Appalachian Regional Reforestation Initiative (ARRI) adopted the Forestry Reclamation Approach (FRA) as a means to restore forest trees on disturbed sites (Burger et al., 2005). The FRA uses the principles of reforestation silviculture to stimulate natural forest succession (Burger, 2011). In this silvicultural system, vegetation types that are compatible with the planting of commercially valuable hardwood species (grasses and legumes) are established, and over time the grass and legume species become less dominant. As the hardwood crop trees grow and with less competition from understory herbaceous species, understory tree species can re-establish and colonize under the crop trees (Burger, 2011). Tree compatible herbaceous covers include annual and perennial grasses and slow-starting, ground-sprawling legumes like white clover (Trifolium repens L.) and birdsfoot trefoil (Lotus corniculatus L.) (Franklin et al., 2012). Planting two different tree types can help to invigorate the site and promote ecosystem diversity and function until the landowner may harvest the crop trees. Additionally the differing life span of the two tree types creates an age class stratification less susceptible to disease and predation (Burger, 2011).

Early-successional and late-successional tree species provide different benefits to an ecosystem (Fekedulegn et al., 2002), but this is something often overlooked in reforestation reclamation practices. Early-successional tree and shrub species are very important to the 
ecosystem by changing micro-climatic conditions and influencing the understory species composition by either competition or facilitation (Alday et al., 2014; Fekedulegn et al., 2002, Chazdon, 2008). More specifically research showed that reclamation sites with higher shrub volume had thicker organic matter layer, possessed more bryophytes overall, and had increased species diversity due to a variety of microclimates (Alday et al., 2014; Huges, 1987).

Furthermore, shrubs are ecosystem engineers, capable of modifying the ecosystem to create heterogeneity in micro-environmental conditions (Alday et al., 2014; Fekedulegn et al., 2002; Huges, 1987). They are also capable of helping to achieve the minimum number of stems and groundcover required for bond release, provide food and cover for wildlife, and can help improve the nutrient status of the soil with mycrohorrizae (Burger and Zipper, 2011). These understory trees and shrubs aid the late-successional trees by serving as habitat for many forest inhabitants, process nutrients and water from the soil, and add organic matter to the surface through leaf litter.

Tree growth is also affected by the site conditions of reclaimed mine sites, and site conditions are highly variable across reclaimed areas (Burger and Zipper, 2011; Skousen and Zipper, 2014). Variability in site conditions, especially in disturbed landscapes, comes from factors including the forest condition before disturbance, the spatial distribution, abundance, and quality of residual vegetation, and the distribution and quality of the disturbance (Chazdon, 2008). As previously discussed, good site preparation is extremely important to ensure success of the reforestation planting. Replacing suitable materials on the surface and controlling factors such as compaction, $\mathrm{pH}$, herbaceous cover, and rockiness will create an environment for successful reclamation plantings (Burger and Zipper, 2011; Skousen and Zipper, 2014; Macdonald et al., 2015). Landscape position, or the slope and aspect, is another important site characteristic in reclamation. In general, NE aspects tend to be better sites for tree growth with cooler temperatures and improved water relationships, whereas SW aspects are generally drier and hotter landscape positions (Burger and Zipper, 2011; Fekedulegn et al., 2002). The magnitude of the effect of aspect and slope on a species is specific and directly related to the unique degree of shade and soil wetness tolerance of the species (Burns and Honkala, 1990; Fekedulegn et al., 2002). 


\section{Part 2: Silvics of the Selected Species Included in the Study}

Table 1 below describes the summary silvics useful for successful establishment for each species. Species growth potential, ease of establishment, and availability are included in the table and serve to help aid species selection. Important site requirements for each species, including shade and moisture requirement are listed as well as the area in the landscape most commonly occupied by that species. Species should be selected based on the conditions of the site to be planted in order to ensure the highest probability of success. Below the summary table includes a more in-depth summary of each species.

Table 1. Summary table of important silvics for establishment of each species.

\begin{tabular}{|c|c|c|c|c|c|c|c|}
\hline $\begin{array}{l}\text { Common } \\
\text { Name }\end{array}$ & $\begin{array}{l}\text { Scientific } \\
\text { Name }\end{array}$ & $\begin{array}{l}\text { Growth } \\
\text { Potential } \\
(\mathbf{m}) \\
\end{array}$ & $\begin{array}{c}\text { Shade } \\
\text { Tolerance }\end{array}$ & $\begin{array}{l}\text { Soil Moisture } \\
\text { Requirement }\end{array}$ & Habitable Zone & $\begin{array}{l}\text { Seedling } \\
\text { Vigor }\end{array}$ & Availability \\
\hline $\begin{array}{l}\text { American } \\
\text { Crabapple }\end{array}$ & $\begin{array}{c}\text { Malus. } \\
\text { Coronaria } \mathrm{L} .\end{array}$ & 15 & Intermediate & Wet & $\begin{array}{c}\text { Stream banks, open woods, } \\
\text { edges }\end{array}$ & Moderate & Good \\
\hline Black Cherry & $\begin{array}{l}\text { Prunus serotina } \\
\text { Ehrh. }\end{array}$ & 38 & Intolerant & Dry & $\begin{array}{l}\text { Forest openings; second } \\
\text { growth forests }\end{array}$ & High & Good \\
\hline $\begin{array}{c}\text { Black } \\
\text { Chokeberry }\end{array}$ & $\begin{array}{l}\text { Aronia } \\
\text { melanocarpa } \\
\text { Michx. }\end{array}$ & 4 & Intolerant & Moist & $\begin{array}{l}\text { Clearings on bluffs or cliffs; } \\
\text { forest coves }\end{array}$ & High & Good \\
\hline $\begin{array}{l}\text { Choke } \\
\text { Cherry }\end{array}$ & $\begin{array}{c}\text { Prunus } \\
\text { virginiana } \mathrm{L} .\end{array}$ & 10 & Tolerant & Moist & $\begin{array}{l}\text { Riparian areas, wooded } \\
\text { draws, steep ravines }\end{array}$ & High & Good \\
\hline $\begin{array}{l}\text { Common } \\
\text { Apple }\end{array}$ & $\begin{array}{l}\text { Malus pumila } \\
\text { Mill. }\end{array}$ & 18 & Intermediate & Moist & $\begin{array}{l}\text { Woodland boarders; } \\
\text { disturbed meadows; fence } \\
\text { rows }\end{array}$ & Low & Moderate \\
\hline $\begin{array}{l}\text { Common } \\
\text { Pear }\end{array}$ & $\begin{array}{l}\text { Pyrus communis } \\
\text { L. }\end{array}$ & 10 & Tolerant & Moist & $\begin{array}{l}\text { Fence rows; open woodland } \\
\text { areas }\end{array}$ & Moderate & High \\
\hline $\begin{array}{l}\text { Eastern } \\
\text { Redbud }\end{array}$ & $\begin{array}{c}\text { Cercis } \\
\text { canadensis } \mathrm{L} .\end{array}$ & 5 & Tolerant & Wet & Understory of open woods & Moderate & Good \\
\hline Elderberry & $\begin{array}{c}\text { Sambucus } \\
\text { canadensis } \mathrm{L} .\end{array}$ & 8 & Intolerant & Moist & $\begin{array}{l}\text { Stream banks, river banks, } \\
\text { forest openings }\end{array}$ & Moderate & Good \\
\hline $\begin{array}{l}\text { Flowering } \\
\text { Dogwood }\end{array}$ & $\begin{array}{c}\text { Cornus florida } \\
\text { L. }\end{array}$ & 10 & Tolerant & Moist & $\begin{array}{c}\begin{array}{c}\text { Flats and lower or middle } \\
\text { slopes }\end{array} \\
\end{array}$ & Low & Good \\
\hline $\begin{array}{c}\text { Gray } \\
\text { Dogwood }\end{array}$ & $\begin{array}{c}\text { Cornus } \\
\text { racemose Lam. }\end{array}$ & 5 & Intolerant & Dry & $\begin{array}{l}\text { Wet or dry sites, borders, } \\
\text { embankments }\end{array}$ & High & Good \\
\hline Hazelnut & $\begin{array}{c}\text { Corylus } \\
\text { avellana } \mathrm{L} .\end{array}$ & 3 & Tolerant & Moist & $\begin{array}{c}\text { Wooded hillsides, } \\
\text { streambanks, coves, bluffs }\end{array}$ & Moderate & Moderate \\
\hline $\begin{array}{l}\text { Highbush } \\
\text { Blueberry }\end{array}$ & $\begin{array}{c}\text { Vaccinium } \\
\text { corymbosum } \mathrm{L} .\end{array}$ & 3 & Intolerant & Wet & $\begin{array}{c}\text { Swamps/bogs; } \\
\text { highelevation balds }\end{array}$ & Moderate & Good \\
\hline $\begin{array}{l}\text { Highbush } \\
\text { Cranberry }\end{array}$ & $\begin{array}{l}\text { Viburnum } \\
\text { trilobum L. }\end{array}$ & 6 & Intolerant & Moist & $\begin{array}{c}\text { Streambanks on lower } \\
\text { elevations }\end{array}$ & High & Good \\
\hline Nannyberry & $\begin{array}{l}\text { Viburnum } \\
\text { lentago } \mathrm{L} .\end{array}$ & 10 & Intermediate & Dry & $\begin{array}{c}\text { Valleys; swamps, } \\
\text { streambanks }\end{array}$ & High & Good \\
\hline
\end{tabular}




\begin{tabular}{|c|c|c|c|c|c|c|c|}
\hline Pawpaw & $\begin{array}{c}\text { Asimina triloba } \\
\text { L. }\end{array}$ & 12 & Tolerant & Wet & $\begin{array}{l}\text { Second growth forests on } \\
\text { ravines; along streams; } \\
\text { floodplains }\end{array}$ & Low & Moderate \\
\hline Persimmon & $\begin{array}{c}\text { Dyospyros } \\
\text { virginiana } \mathrm{L} . \mathrm{f} .\end{array}$ & 16 & Intermediate & Dry & $\begin{array}{l}\text { Rich bottomlands along } \\
\text { floodplains }\end{array}$ & Moderate & Moderate \\
\hline $\begin{array}{c}\text { Red } \\
\text { Mulberry }\end{array}$ & Morus rubra L. & 25 & Tolerant & Moist & $\begin{array}{l}\text { Cove environments; } \\
\text { floodplains }\end{array}$ & Moderate & Good \\
\hline Serviceberry & $\begin{array}{l}\text { Amelanchier } \\
\text { arborea } \text { Michx. } \\
\text { f. Fernald }\end{array}$ & 10 & Tolerant & Moist & $\begin{array}{l}\text { Swampy lowlands, rocky } \\
\text { ridges, open woodlands }\end{array}$ & High & Good \\
\hline $\begin{array}{l}\text { Washington } \\
\text { Hawthorn }\end{array}$ & $\begin{array}{l}\text { Crataegus } \\
\text { phaenopyrum } \\
\text { L.f. }\end{array}$ & 7 & Intermediate & Moist & $\begin{array}{l}\text { Uplands; coves; } \\
\text { bottomlands }\end{array}$ & High & Good \\
\hline Wild Plum & $\begin{array}{c}\text { Prunus } \\
\text { Americana } \\
\text { Marshall }\end{array}$ & 10 & Intolerant & Moist & $\begin{array}{l}\text { Mixed hardwood stands; } \\
\text { open areas }\end{array}$ & High & Moderate \\
\hline
\end{tabular}

\section{American Crabapple Malus coronaria $\mathrm{L}$.}

A member of the Rosaceae family, the crab apple is native to much of the eastern United States and eastern Canada along stream banks, open woods, and woodland edges (USDA, 2016). It is described as a perennial tree possessing autumn foliage, white or pink flowers in May-June, and green fruit developing in July-August. The plant can crow up to $15 \mathrm{~m}$ tall, most commonly falling in the range of 4 to $12 \mathrm{~m}$ (USDA, 2016). This height of growth places the crabapple into the small upright tree group. Optimal growth of crabapple plants is dependent on maintaining moist soil conditions and partly shaded light conditions (USDA, 2016). The crabapple plant is inherently very susceptible to rusting as a result of too wet growing conditions and are moderately susceptible to salty conditions. Crabapple trees are widely commercially available in the eastern United States.

The crabapple is beneficial for wildlife because crabapple trees are used as nesting sites for birds, for shelter by many animals, and as a food source for many animals. The tree has edible flowers, and additionally these flowers have a special value for native bees, bumble bees, and honey bees because they are nectar-rich plants.

\section{Black Cherry Prunus serotina Ehrh.}


This species belongs to the Rosaceae family, and is described as a perennial dicot shrub/tree. It is found abundantly in most of North America concentrated in the eastern US, is naturalized in South America, and is also considered to be an invasive species in Western Europe. There are many geographic variants within the black cherry species. The species is considered to be an early-successional plant commonly found in forest openings in mesic woods or second-growth hardwood forests below 1520-meter elevation. Black cherry trees can grow as individual trees or form clumps. They are shade and flood intolerant, and therefore are seldom found in latesuccessional deciduous forests (Burns and Honkala, 1990). The species is also found to be adversely affected by saline environments. Black cherry trees can grow up to $38 \mathrm{~m}$ tall in the eastern United States. The oldest black cherry tree recorded is 250 years old, however the average age of the species is between 80 and 100 (USDA, 2016).

The bark of mature black cherry trees is described as thin, scaly, and fissured (Burns and Honkala, 1990). The species possesses alternate, simple, and ovate to oblong-lanceolate leaves that have fine toothed edges. Red hairs found on the midrib of the leaf near the base are commonly the distinguishing factor in identifying black cherry plants in the field (USDA, 2016). Prunus serotina's leaves are described as the thinnest of the black cherry variants. The tree flowers between May and July, producing a long cylindrical raceme measures $10-15 \mathrm{~cm}$ long that possesses multiple flowers (USDA, 2016). The flowers are white or pink and have five petals. Black cherry plants produces a berry-like fruit between June and October that is red and turns black when ripe. The berries are $8-10 \mathrm{~mm}$ long in diameter and produce a single seed. The tree is only able to produce seed after 10 years with maximum seed production in black cherry trees occurring between the ages of 35 and 100 (Burns and Honkala, 1990). The plant will produce seed annually, but the species produces the greatest amount of seed every 5 years based on specific climatic factors (Burns and Honkala, 1990). However although the plant may produce seed annually, seeds generally require a period of 3 years in order to germinate and a period of cold stratification. This growth characteristic causes a large seed bank of black cherry to be present in the forest soil at all times, but because of the species intolerance to shade they are unable to survive. This seed bank is the mechanism by which black cherry dominates the understory of many forests after major disturbance or fire. The black cherry species is also able to reproduce after a cutting or fire through stump sprouts (Burns and Honkala, 1990). However, black cherry trees characteristically thin bark makes them susceptible to girdling in fire conditions. 
The black cherry tree is widely used as a furniture and cabinet wood, and additionally it is used for other home construction materials (USDA, 2016). The fruit of black cherry trees has been used in making wine and jellies for human consumption. Black cherry twigs and buds, flowers and fruits, and bark are considered a very important food source and are heavily browsed by numerous forest fauna including all sized herbivores, game girds, and numerous carnivores. However these edible plant parts of black cherry also produce cyanogenic glycoside, a compound capable of poisoning livestock animals when they ingest wilted leaves (USDA, 2016). Black cherry is also considered a medicinal plant because the glycoside produced in the inner bark of the tree is used as a sedative, tonic, and remedy for coughs. It has also been a species used for reclaiming surface mine spoil and rehabilitating other disturbed land with successful results when the planting stock was aged 1 year or older and direct seeding was not used. It is a commonly planted tree and is widely available in nurseries in the United States. Potential problems for growing black cherry include black knot, the eastern tent caterpillar, and the cherry scallop shell moth (USDA, 2016). Black knot is caused by a fungal disease and manifests itself in black growths on the woody portions of the plant. The eastern tent caterpillar and the cherry scallop shell moth defoliate black cherry plants leading to a loss of growth and ultimately mortality for the tree.

\section{$\underline{\text { Black Chokeberry Aronia melanocarpa Michx. }}$}

Black chokeberry is a cold-hardy deciduous shrub belonging to the Rose family and is native to the northeastern United States. The plant is hardy to zone three, with distribution in the south limited to high elevations in the Appalachian Mountains (USDA, 2016). Black chokeberry plants grow in drier thickets of forest, clearings on bluffs or cliffs, and alternatively in a moist forest environment. It prefers full-sun, but can tolerate a moderate amount of shade. Black chokeberry prefers well-drained moist soils, and is not considered drought-tolerant (USDA, 2016). When black chokeberry plants do not get adequate sunlight or air circulation, the plants mildew and this adversely affects growth and health of the plant.

Black chokeberry plants can grow 1 to $4 \mathrm{~m}$ tall depending on environmental conditions. The plant possesses hairless green leaves that have raised glands along the midrib, and in the field these leaves are most often identified by their fine-toothed margins (USDA, 2016). These leaves change and become a glossy deep green before flowering and then change colors in the late summer and fall to a yellow or reddish color. In the spring, black chokeberry produces white 
flowers with five petals and pink anthers. They are bisexual and grow in a clustered formations measuring $5 \mathrm{~cm}$ across. The pome fruit produced by the plant appears in mid to late summer, and as it ripens it changes from a red to a purplish-black color (USDA, 2016). The pomes begin to drop from the plant after they ripen. In one pome, there are approximately one to five seeds. Seeds are the main mechanism for reproduction of black chokeberry. The produced seeds are small, measuring 10 to $20 \mathrm{~mm}$ long (CBG, 2016). In order to achieve the greatest germination rates, the seeds internal dormancy must be overcome. This can be done by stratifying the seed in peat for three months with a constant temperature between 0 and $10^{\circ} \mathrm{C}(\mathrm{CBG}, 2016)$. There are few diseases and pest problems that affect black chokeberry.

Black chokeberry plants are a commonly selected shrub in landscaping because of their colorful foliage and white flowers (CBG, 2016). The species is considered a very important wildlife food crop, with deer, rabbits, and other large herbivores found commonly browsing the leaves, twigs and buds, and flowers and fruits, and the fruits of the plant getting eaten by grouse and other gamebirds and songbirds (USDA, 2016). Black chokeberries are also considered an economic crop because there is a major market for the fruit in health-fruit drinks, jellies, and as a natural color in the food industry. This is accredited to the large number of anthocyanins and flavonoids in the black chokeberry pome fruits.

\section{Choke cherry Prunus virginiana L.}

A member of the Rosaceae family, chokecherry is a tall shrub or a small tree found in many areas with varying soil and water conditions. It is a deciduous, perennial, multi-stemmed woody plant capable of reaching a height of $10 \mathrm{~m}$ and possessing an irregular crown 3 to $8 \mathrm{~m}$ wide when mature. The leaves of the chokecherry are oval or elliptic in shape with toothed margins, about $10 \mathrm{~cm}$ long, 2 to $5 \mathrm{~cm}$ wide, and glossy on the visible side and paler on the underside (USDA, 2016). They are arranged in a simple alternate pattern on the plant. Although rare, the chokecherry species has the ability to form thickets. In autumn, the leaves of the chokecherry plant turn yellow. The bark of the plant darkens with age, starting out as a gray or reddish brown and turns to a brownish-black furrowed bark. Chokecherry bark is distinguished by the bark's horizontal lenticels on the younger bark. Chokeberry flowers are arranged in 6- to 15-cm-long racemes on the current year's twig growth, they are perfect and aromatic flowers with five white petals (USDA, 2016). Prunus virginiana flowers from April through July, and fruits form months later. The drupe fruit that forms on chokecherry plants ranges in color from 
red to purple depending on cultivar and is globose. The roots on the chokecherry plant are made up of an extensive rhizome network (USDA, 2016). These rhizomes can reach $2 \mathrm{~cm}$ in diameter and extend beyond the plants drip zone $10 \mathrm{~m}$ away from the base of the tree.

There are environmental concerns associated with the chokecherry plant because the seeds, leaves, and stems produce toxic hydrocyanic acid (USDA, 2016). This raises a management concern for the planting of Prunus virginiana in wildlife or livestock grazing areas. Many different organisms including bear, birds, and rodents will consume and distribute the fruits of the chokeberry plant. It is considered a potential hazard in rangeland because common livestock species are adversely affected by the plant if they consume $25 \%$ of their body weight. In order to combat this, many rangeland owners use mechanical and chemical treatments to control chokecherry as well as try and maintain a full and healthy grassland so that chokecherry seeds cannot as easily establish (USDA, 2016).

Establishment of the chokecherry plant is relatively simple, because the plant is able to inhabit such a wide area. The seed is commonly found in nurseries and seed sources nationwide. In general the plant requires $35 \mathrm{~cm}$ of rain annually (USDA, 2016). Chokecherry plants are susceptible to salt and sulfur dioxide pollution. The biggest hindrance for establishment of this species is competition. Weed barrier mats, herbicide treatments, and continued management of the planted area is suggested in order for chokecherry plants to thrive (USDA, 2016). On the other side of that problem, in some areas the chokecherry plant is considered to be invasive or a weed. Other problems commonly faced when establishing chokecherry plants includes Xdisease, black knot, stem decay, shothole, Valsa canker, and honey fungus (USDA, 2016).

Browsing by deer and rodents in the early phase of establishment for this plant can also impede the plant's chance of survival.

The chokecherry species' most common use today is as a food source, from which syrups and jellies are produced. Another use for the species is in conservation plantings where they are used in shelterbelts and windbreaks for erosion control, and wildlife plantings (USDA, 2016). In wildlife plantings, the chokecherry plant is commonly used as not only a food source but also provides habitat for the eastern tent caterpillar. The plant is also a common ornamental that is becoming more requested by commercial nurseries.

Common Apple Malus pumila Mill. 
The apple species is part of the Rosaceae family, and was a naturalized perennial tree in the United States originally from Eurasia (Burns and Honkala, 1990). It reaches a wide range of heights at maturity depending on cultivar, the range between 4 and $18 \mathrm{~m}$. They are commonly found in woodland borders, disturbed meadows, abandoned orchards, old homesteads, areas along roads, and along fence rows (USDA, 2016). The common apple species prefers sites possessing a loamy soil with full sun and well-drained conditions. The fruit produced by a wild or unmanaged apple tree will be the same as those cultivated in orchards, except the wild type fruit will be noticeably smaller than the managed apple fruit (Burns and Honkala, 1990).

Species specific characteristics include a short, reddish gray, and irregularly fissured crooked trunk with a globoid crown with spreading crooked branches (Burns and Honkala, 1990). Branch bark of the plant is more reddish brown to brown with white pubescent lenticels. New shoot growth is described as very pubescent, terete, and a light gray-green to purple. Lanceolate or ovate leaves with finely serrated leaf margins appear on the branches in an alternate pattern, and are between 5 to $8 \mathrm{~cm}$ long and between 2 to $5 \mathrm{~cm}$ wide. The top side of the leaves are yellowish green and near hairless, however the underside is more of a pale green or whitish and has fine hairs (USDA, 2016). The tips of each leaf are pointed, however the leaves are more round near the base. These leaves turn a yellow hue in the fall.

The flowers of the apple tree are relatively large, measuring about $3 \mathrm{~cm}$ across. These flowers form in clusters from short spur twigs. Flowers range in color from white to pink and has five petals and five smaller sepals (USDA, 2016). The flowering period for the common apple is about two weeks, and the flowers are extremely fragrant. The flowers of the apple tree plant must be cross pollinated from other compatible trees in order to set fruit. During the summer, small green pomes replace fertile flowers and they continue to grow into late summer or early fall. Each pome fruit contains 10 brown flat and ovate brown seeds (Burns and Honkala, 1990). The flavor of the apple fruit has a wide range, and can be very sweet or in contrast very sour.

The success of apple tree cultivation is dependent on site and environmental conditions. As previously mentioned, apple trees are widely distributed in the United States and prefer welldrained, sunny areas with loamy soils (USDA, 2016). Perhaps the biggest hindrance to apple tree cultivation success is the species' susceptibility to many pests and disease organisms (IWF, 2016). The species is also very susceptible to wildfires and is moderately affected by salt 
pollution. Because of the apple trees reliance on cross-pollination, the success of the tree is dependent on the availability of numerous pollinators in order to produce fruit (IWF, 2016).

Uses for the apple tree include a food source and orchard crop, the wood and wood chips are used for culinary purposes as well as in construction, and the species is a common wildlife crop (USDA, 2016). Many birds, rabbits, bears, and rodents feed on the fruits produced by this tree. These animals that eat the fruit spread the seed to new locations. The apple tree also can provide a habitat for many nesting birds. Also as previously stated, many pollinators enjoy this species and its existence in their area is beneficial to both them and the apple tree species.

\section{Common Pear Pyrus communis L.}

The common pear species is a member of the Rosaceae family and is distributed across the United States and Canada. This species like common apple is considered a naturalized species in the area originally from Asia, and also like the common apple it originated from domesticated cultivars in North America that had naturalized and cultivated outside of managed areas (Burns and Honkala, 1990). The common pear species is found along old fencerows and in open woodland areas in the Eastern United States, in well-drained loam soils rich in humic material (USDA, 2016). There is evidence the Pyrus communis is also tolerant of very clayey soils. The species is shade tolerant, although does not fruit as well in shaded conditions. The plant is drought-tolerant after establishment. The species does not do well in very acidic soils and exposed positions (MBG, 2016).

Common pear is considered to be a true tree species because of its upright branching and pyramidal shape, and has the ability to reach heights of $10 \mathrm{~m}$ at maturity (Burns and Honkala, 1990). The leaves of the tree are dark green, approximately $10 \mathrm{~cm}$ long, glossy, elliptic shaped, and have crenate to serrate margins. In the fall, these leaves turn yellow or red in the fall (USDA, 2016). The flowers produced by the plant are five petaled, white or occasionally pink, and appear in corymbs in early spring or summer in branchlets. These flowers develop into edible fruit that ripen from late summer into the fall. Common pear will produce fruit after 4 or 5 years of age (MBG, 2016). Like common apple, this species is reliant on cross pollination.

The most common use for the common pear species is as a food crop. This plant is most often grown in managed situations for its fruit, much like the common apple species. However, the 
common pear is found to be a moderately important food source for terrestrial birds and small mammals (MBG, 2016).

Problems facing these species in the eastern US include fire blight and the invasive brown marmorated stink bug (USDA, 2016). The species is also slightly susceptible to ozone pollution. Both problems affect many tree species that produce similar fleshy fruits.

\section{Eastern Redbud Cercis canadensis L.}

This species is a member of the Fabaceae family and is distributed in the eastern United States and the Great Plains region, but is not found in the western United States (USDA, 2016). It is an understory tree species often found in scattered small populations in the open woods. Eastern redbud prefers south-facing slopes that get more sunlight than north-facing slopes (Burns and Honkala, 1990). Eastern redbud has the ability to grow over a wide range of soil $\mathrm{pH}$, although best growth is seen in substrate with a $\mathrm{pH}$ range of 7.5 or higher. Cercis canadensis favors most loam or sandy soils in valleys and bottomlands, and will not grow on poorly-aerated sites that consist of coarse sands (Burns and Honkala, 1990). The plant is considered to be hearty in the eastern United States region, and will develop a large taproot when in advantageous growing conditions for the plant. The species is moderately susceptible to ozone and light pollution.

The eastern redbud species flowers between March and May before leaf growth (USDA, 2016). This is the first pop of color in the forest throughout much of the eastern United States.

The flowers produced by the plant are produced on old twigs, branches, and trunks and after blooming these flowers give way to new leaf growth. The leaves of the plant emerge between April and May and are described as heart shaped. They are arranged alternately, $10 \mathrm{~cm}$ wide on average, and possess prominent venation (USDA, 2016). The twigs of the plant are slender, spreading, and short or dark brown knotty spurs. The seed produced by the plant are flat green pods that contain between four and 10 seeds. These pods turn from green to dark brown or black when mature. Seeds produced are spread mainly by wind and animals, which is an environmental concern in some areas where this species is considered to be more invasive. (Burns and Honkala, 1990)

Eastern redbud is a very important wildlife species in the eastern United States. The plant is utilized by hummingbirds, honeybees, and for its early pollen production (USDA, 2016). Larger 
forest mammals like whitetail deer, squirrels, and songbirds browse on the plants new woody growth, flowers, and seeds. Livestock species are said to also graze on the foliage and twigs of this species. The Native Americans used the plant to treat both whooping cough and dysentery by making a tea from the plants bark.

\section{Elderberry Sambucus canadensis L.}

The elderberry is a member of the Caprifoliaceae family and native to much of the United States and Canada. It is commonly found in sunny areas along stream banks, river banks, and openings in forest habitats such as slopes, canyons, cliff bases, and open places in riparian areas lower than < $3000 \mathrm{~m}$ (Burns and Honkala, 1990). The plant prefers a neutral or slightly acidic well drained soil (USDA, 2016). It is a perennial dicot plant that has the growth habit of a shrub, growing 2-8 $\mathrm{m}$ tall. The plant flowers from May until September, and the inflorescences are white or cream, five-lobed, flat on the top, bigger across than it is tall, has 4-20 cm diameter, bisexual, and have a rancid odor (Burns and Honkala, 1990). It fruits on from July through September, and produces clusters of purple or black berries that measure 5-6mm wide on both new and old wood (Wilkinson, 1948). The fruits have three to five nutlets, and a waxy bloom that gives the berries a bluer color (USDA, 2016). Elderberries produce seed every year, the seeds are dispersed by birds and other wildlife, and the seeds are viable for 16 years due to a thick seed coat. The elderberry plant is also considered to be allopathic, producing a phenolic compound that adversely affects the growth of Douglas fir plants (Burns, 1990 and Wilkinson, 1948).

As a wildlife crop elderberry has proven to be a useful range plant for livestock, large and small herbivores, game birds, song birds, and large and small carnivores. Animals utilize the leaves, twigs and buds, flowers and fruits, and the bark of elderberry plants (USDA, 2016). The elderberry plant is available for use as a food source all year around, with the greatest use period being in the summer when berries are present.

\section{Flowering Dogwood Cornus florida L.}

Flowering dogwood belongs to the Cornaceae family and is a native plant to North America, its range stretching from Ontario to Mexico. Dominant soils in the range of flowering dogwood, in decreasing order of importance, include Ultisols in the South and East, Inceptisols in the Appalachians, Alfisols in the Midwest, Spodosols in New England and Florida, and 
Entisols in scattered areas of the Southeast (Burns and Honkala, 1990). This flowering tree is able to reach heights of $10 \mathrm{~m}$ at maturity and can spread to $10 \mathrm{~m}$ (USDA, 2016). Flowering dogwood plants are commonly found in ornamental plantings both commercially and residentially and is regarded as one of the most common selected ornamental plants in the eastern United States.

Cornus florida favors moist, acidic soils rich in organic matter in partial shade, and welldrained soils with full sun to part shade (USDA, 2016). Flowering dogwood is often found on the flats and on lower or middle slopes, but rarely on upper slopes and ridges. It is sensitive to both light and ozone pollution. The plants growing habit is broadly pyramidal but somewhat flat topped and is a low branching plant (Burns and Honkala, 1990). The plant flowers early in the spring like the eastern redbud species, between March and May (MBG, 2016). The frequency of flowering will increase as the draining capability of the soil increases and is subsequently decreased in poorly-drained soils (USDA, 2016). This is related to the shallow root system this species possesses. Flowering dogwood flowers are small and yellowish green and grow in compacted clusters on the tree. The showy, white four petal like bracts that surround each flower give the appearance that the plant produces large white flowers (USDA, 2016). Leaves of the tree are dark green, oval shaped, about $12 \mathrm{cn}$ long, and turn a red shade in the fall. The small red drupe fruit produced by the tree in late summer or early fall is said to be poisonous to humans by some authors, but is loved by birds and other wildlife (Burns and Honkala, 1990). These fruits persist into late into the year.

There are many problems with establishing the flowering dogwood species. These include the very common dogwood anthracnose, powdery mildew, leaf spot, canker, root rot, and leaf and twig blight (USDA, 2016). Leaf miner and scale are potential problems of the species, although their effect is not as severe as dogwood anthracnose. The flowering dogwood species is more susceptible to diseases and pests when grown in conditions not favorable for the species growth. This makes soil testing and site selection very important for determining the success of flowering dogwood plantings. As previously stated, the most limiting factor for dogwood success is soil drainage due to the species very shallow root system.

Flowering dogwood is considered to be a plant that improves soil conditions because it produces leaf litter that decomposes at a much faster rate than other species, and therefore cycles nutrients in the soil faster (Burns and Honkala, 1990). In the south, flowering dogwood is the 
most dominant understory species in loblolly pine plantings. As stated previously this species is a very important ornamental species and is grown in many nurseries and greenhouses in the United States (MBG, 2016). As a wildlife crop, the dogwood species is a very important food source for birds, deer, rodents, and more forest mammals as it is rich in calcium and fat content. The fruit, bark, seeds, flowers, leaves, and twigs are all edible and consumed by a variety of members in the forest ecosystem (USDA, 2016). The species is also an important cover and nesting species for wildlife. Flowering dogwood is also a lumber source used for things that require a hardwood capable of withstanding many uses.

\section{Gray Dogwood Cornus racemose Lam.}

Gray dogwood belongs to the Cornaceae family, is native to the eastern United States, and tolerant of many growing conditions including flood and drought (USDA, 2016). Unlike flowering dogwood, gray dogwood is considered to be a shrub that grows in an irregular to rounded shape, however there are some cases where the plant was pruned to grow more like a tree (USDA, 2016). This species is most commonly planted for either visual interest and for its flower production in spring.

Gray dogwood shrubs can reach heights of $5 \mathrm{~m}$ with their spread reaching $5 \mathrm{~m}$ at maturity as well. The shrub is described as a slow growing plant, annually increasing in size only $30 \mathrm{~cm}$ or less (USDA, 2016). This plant can tolerate full to part sun, preferring full sun and partial shade with a minimum of 4 hours of direct sunlight daily. As stated earlier, this species can adapt to a wide range of soil conditions and can adapt to wet sites, dry sites, naturalized areas, neglected areas, borders, embankments, and mass plantings (USDA, 2016).

Characteristics of the gray dogwood species include oppositely arranged narrow greenish gray leaves measuring $8 \mathrm{~cm}$ in length, which are elliptical and acuminate with no major leaf veins (USDA, 2016). In the fall these leaves turn a variety of colors including purples and reds. The flowers produced by the plant are white or cream and hemispherical in shape, and the plant flowers for 7 to 10 days in July. The fruits produced by this species are appear in late summer, are creamy white, very small, and grow in clusters (USDA, 2016). The hemispherical pedicels that are the fruit base persist throughout the season even after the fruit drops and are bright red in color. Twigs of gray dogwood plants are thin and reddish. Buds produced by this species are slightly lighter colored and also very small. Twigs turn from reddish brown to a darker gray as they mature and very distinct blocks form on the older bark like in the flowering dogwood 
species (USDA, 2016). As many true shrub species, the gray dogwood species lack one distinct basal stem and instead has more of a spreading growing habit.

Uses for gray dogwood include mass plantings, embankments, borders, and barrier hedges due to the spreading growth habit possessed by this species. This makes this species useful for erosion control and in shelterbelt plantings (USDA, 2016). The species is also a very popular food source for many wildlife species in the forest ecosystem including birds and many terrestrial mammals. They utilize the leaves of the plant, its twigs and bark, and the fruit that the gray dogwood produces. It is useful as a cover species, as a food source, and as nesting material (USDA, 2016).

This species does not have as many establishment challenges as flowering dogwood and is better able to adapt to growing conditions. Therefore, this plant does not experience as much stress as flowering dogwood and is not as affected by as many diseases and pests (USDA, 2016). However, this species is still affected by powdery mildew in wetter regions.

\section{Hazelnut Corylus avellana L.}

The hazelnut plant is a multi-stemmed, deciduous shrub that belongs to the Betulaceae family (USDA, 2016). Although this plant is not native to North America it is considered a naturalized species in Zones 4 to 8 and does not possess invasive characteristics that could cause environmental problems. This species, Corylus avellana, is sometimes called English filbert, Harry Lauder's walking stick, or European cobnut/hazel and is able to reach a maximum height of $3 \mathrm{~m}$ (MBG, 2016).

The species thrives in well-drained, moist soils rich in organic matter that receive full sun or partial shade (USDA, 2016). The species is said to be shade tolerant but unable to tolerate clayey soils (USDA, 2016). There are no serious problems posed by pests or pathogens for this species although hazelnut is affected by black knot, crown gall, apple mosaic virus, and leaf spot. There is also evidence that the Japanese beetle (Popillia japonica) feeds on the foliage of the plant. The first thing to appear on the bare gray-brown branches in March - April are the plants flowers (USDA, 2016). The hazelnut plant has male and female flowers on the same plant, and these flowers differ morphologically. The male flowers are flashier and are a yellowish white in color. These appear in 8-cm long sessile drooping catkins. Just above these catkins are where the more subtle female flowers are located, identified by their red stigmas. 
Next to appear on the plant after flowers bloom are the pubescent leaves rounded to cordate at the base (USDA, 2016). These leaves are double serrated, elliptic to ovate to orbicular in shape. These leaves turn a yellow hue in the fall. Fruit produced by hazelnut, commonly referred to as cobnuts, appear after flower pollination and ripen between August and September in terminal clusters of 1 to 4 nuts. These fruits are surrounded by hard husks that extend beyond the cobnut at least an inch in order to form a break.

The nuts from this plant are edible for both wildlife and humans, although fruit produced from this wild type species are more wildlife species than for human consumption. The hazelnut fruit is a popular food source for forest mammals, especially squirrels. The largest producer of cultivated hazelnuts in the United States is Oregon (MBG, 2016).

\section{Highbush Blueberry Vaccinium corymbosum L.}

The highbush blueberry species is a crown-forming deciduous shrub widely distributed across North America. It is found in Canada and as west as to Oklahoma, but is rare in West Virginia (USDA, 2016). The species is commonly found in a wide variety of site conditions but rarely dominates the ecosystem, except in swamps, bogs, and high-elevation balds in the intermediate stages of forest succession (Burns and Honkala, 1990). The species is most commonly found in low elevations close to a water source or in open areas of moisture rich forests with acidic, well aerated soils rich in organic matter and low in phosphorus and nitrogen (USDA, 2016). This species is shade intolerant and has the ability to survive long periods of flooded conditions.

The species has two to five stems that arise from a single point, and the plant usually around 6 $\mathrm{ft}$ in height and can achieve a maximum height of $2.5 \mathrm{~m}$. The bark of the plant is yellow-green when new, and fades to a more reddish color in the winter time. The leaves of the plant are alternately arranged, simple, elliptic or ovate in shape, between 2 and $8 \mathrm{~cm}$ long, slightly waxy, and are possess pubescent veins on their undersides. White pink small flowers produced by the species bloom during May in West Virginia, appear as the leaves unfold on the plant, and bloom for a maximum of 25 days (Burns and Honkala, 1990). They have five petals that form into an urn shape and appear in clusters with around 10 flowers in each cluster (USDA, 2016). The flowers are mainly pollinated by bees, and are commonly dispersed by animals. Blueberry plants rarely produce rhizomes, and usually reproduces by seed. The berry fruit produced by the species are half an inch in diameter and contain several seeds in each berry (USDA, 2016). The fruit appear on the plant approximately 62 days after flowering between July and August in the central 
Appalachian region. The blueberry species produces fruit annually, and benefits from crosspollination. The seeds produced by the plant require cold stratification before germination happens due to the thick seed coats possessed by the seeds, and as a result germination usually happens in the winter following when the seed is spread in the spring (Burns and Honkala, 1990).

The species is an important later summer and early fall food source for numerous bid species including turkey, songbirds, and quail. Mammals are also consumers of the fruit produced by the plant and include bear, fox, rabbits, squirrels, and rodents. The species is commercially harvested by humans in North America, and is considered to be a nutritional super food rich in fiber and vitamin $\mathrm{C}$. There are also medicinal value to the species.

\section{Highbush Cranberry Viburnum trilobum L.}

Highbush cranberry is distributed naturally in Canada and the northern America in USDA hardiness Zones 2 to 7, with West Virginia being one of the southern most states in the native range. The deciduous shrub belongs to the Adoxaceae family.

The plant is able to grow in a wide range of soil $\mathrm{pH}$ and soil moisture conditions and is described overall as a durable plant species (USDA, 2016). Highbush cranberry prefers sites that possess well-drained loamy soils with a $\mathrm{pH}$ within the range of 6.6 to 7.5 that receive full sun to partial shade along streambanks on lower elevations (USDA and UMN Extension, 2016). The species is alternatively able to handle adverse conditions including sites with poor drainage, drought, semi-shade, heavy clay soils, and high soil $\mathrm{pH}$. The plant usually reaches a height between 3 and $6 \mathrm{~m}$, has a growth rate described as medium in speed for a deciduous shrub (UMN Extension, 2016. Because the species is a true shrub it has many does not have just one basal stem. The species does not pose an invasiveness character by spreading due to the dense growing habit and close branching of the species (USDA, 2016). Leaves of highbush cranberry measure 5 to $12 \mathrm{~cm}$ in length, are oppositely arranged, and are three-lobed leaves that resemble maple leaves (USDA, 2016). The white hermaphroditic shrubs produced by highbush cranberry plants that appear in between May and June. Each flower blooms in a double ring formation where the fertile flowers are smaller and located on the inner ring and larger sterile and flashier flowers are located on the outer ring (USDA, 2016). These flowers are most commonly pollinated by bees (UMN Extension, 2016). The fruit produced by the shrub are small bright red berries that 
resemble cranberries. They appear in clusters in between July and August in the Appalachian region, and if not disturbed can stay on the plant for duration of winter (UMN Extension, 2016).

Once the species is established, the plant becomes very dense and provides for a useful shrub to plant in barrier, border, and screening plantings (USDA, 2016). The most successful plantings of highbush cranberry included bareroot or containerized seedlings 2 years in age or older (UMN Extension, 2016). The fruit produced by the plant are a popular food source for many birds and forest mammal inhabitants, especially in the winter months because of the ability of the fruit to remain on the flower stalks throughout the winter months. The twigs of the shrub are commonly browsed on by deer and rodents. The very sour berries produced by the plant are also consumed by humans, once sweetened, in preserves and are a good source of vitamin C.

\section{Nannyberry Viburnum lentago L.}

Nannyberry is a multi-stemmed shrub that belongs to the Caprifoliaceae family and is native to much of North America including the much of Appalachia (USDA, 2016). Other common names for the species include sheepberry and wild raisin. The species is described as leggy at its base when mature and is able to reach heights between 6 and $10 \mathrm{~m}$. The species is known for its suckering capability, although it does not pose a threat of invasiveness (USDA, 2016). The growing rate of nannyberry overall is described as medium and the species grows in an irregular almost round shape.

The species is commonly found in low elevation forests, around the edges of swamps, in close proximity to streambanks, and in rich valleys (USDA, 2016). They can also be found in more upland forest ecosystems, but this is less common. Nannyberry plants prefer loamy or clayloam soils, but is able to survive in soil that is moist or dry and sandy or rocky. Shade tolerance is a characteristic nannyberry plants have, but larger nannyberry plants are found in environments where nannyberry plants receive more sunlight (USDA, 2016). The plant flowers between May and June and produces fruit between July and September. The flowers produced by nannyberry plants are small and white, and grow in large 5 to $12 \mathrm{~cm}$ flat topped clusters (USDA, 2016). The fruit produced by the species hang in the flower clusters and are drupe berry-like fruits that change color from green to red to finally blue-black in the late summer. These fruits contain seeds, the primary form of reproduction for the species (USDA, 2016). The bark of the species is dark gray when new growth and as it ages it turns into a blacker color and displays distinct patterns of small blocks when mature. Leaves of the species are simple, oppositely arranged, 
elliptic-obovate to ovate in shape, between 5 and $10 \mathrm{~cm}$ long, glabrous on both sides, come to a long point, and have finely toothed margins (USDA, 2016). The leaves like the bark of the species darken and glossy with age.

Uses for the plant include landscape plantings, shelter and barrier plantings, for windbreaks, and as a wildlife species. The species is selected both for the color of the leaves in both the spring and fall, for the annual display of flowers produced, and for their fast and dense growing habit. Nannyberry fruit is consumed by numerous bird species as well as a wide variety of forest mammals. Nannyberries are also consumed by humans in small quantities, and stomach problems are associated with eating large quantities.

\section{Pawpaw Asimina triloba L.}

Pawpaw is a small deciduous tree species belonging to the Annonaceae family that exhibits clonal growth (Burns and Honkala, 1990). It is naturally distributed to the eastern United States reaching as far west as Texas, and is very common in the Appalachian region. The species is able to dominate some ecosystems, can reach heights between 6 and $12 \mathrm{~m}$, and is able to produce dense thickets (USDA, 2016). Pawpaw prefers mature second-growth forest type ecosystems on the slopes of ravines, along streams, and in floodplains. It prefers deep, rich, damp, sandy, or clayey soils. The species is shade-tolerant, but cannot survive in old-growth forests (Burns and Honkala, 1990). The species is not an aggressive native species, in commercial forest stands pawpaw numbers are managed because they can suppress economic crop growth by creating a dense canopy cover.

Unlike the shrub species included in this study, the pawpaw species has one basal stem. The bark possessed by the pawpaw plant is thin and shallow that has very characteristic irregular fissures (USDA, 2016). The young twig growth is pubescent, soft, and lighter in color in comparison to older bark which is darker in color, smooth, and hard. The leaves of the pawpaw plant are alternate, long ovate or elliptical leaves up to $30 \mathrm{~cm}$ in length, and odorous when bruised (USDA, 2016). The fruit produced by the pawpaw species is a large berry that contains approximately five large seeds in each berry. Pawpaw reproduction occurs sexually by selfpollination rarely or by cross pollination by flies or nitidulid beetles more commonly (Burns and Honkala, 1990). The fruit set of pawpaw is relatively low in comparison to the number of flowers produced by the species (Burns and Honkala, 1990). 
Pawpaw fruits are commonly consumed by many birds and mammals, as well as humans. Deer and rodents browse the bark of pawpaw trees. Wood produced by the species is light, soft, coarse-grained, and weak and subsequently does not hold much economic value (USDA, 2016). The species also has medicinal value due to the alkaloid contained in the seed of the trees asiminine. There is also an alkaloid produced in the bark, analobine, which is beneficial for human health.

\section{Persimmon Dyospyros virginiana L. f.}

The persimmon tree species belongs to the Ebenaceae family, and is naturally distributed widely across in the southeastern United States in humid, rich bottom lands along floodplains (Burns and Honkala, 1990). It is less common in oak-hickory forests of the Allegheny Plateau and in the main range of the Appalachian mountain system (Burns and Honkala, 1990). In the south Atlantic and Gulf states, persimmon is often the first tree species to encroach onto abandoned and disturbed lands as it is well adapted to drought and full-sun conditions. The species is shade-tolerant, and can persist as an understory species for years (USDA, 2016). It is able to survive in sterile, flooded, and dry soil conditions, but prefers soils classified as Alfisols, Inceptisols, Ultisols, and Entisols (Burns and Honkala, 1990).

The species is easily cultivated from seed and the most successful plantings from seed are sown $1 \mathrm{~cm}$ into the soil profile in spring and fall with a humic amendment. The growth rate of the species is generally considered to be slow with $90 \%$ of radial growth completed 100 days after growth starts in spring (USDA, 2016), and although growth is possible on sites with adverse conditions the persimmon plants found are often stunted in growth. Additionally to stunted growth, persimmons lose economic viability when they are grown in adverse conditions because the wood produced has very high percentages of heartwood.

The persimmon species grows as a moderately sized tree species between 8 and $16 \mathrm{~m}$ tall when mature when grown in compatible growing conditions. The plant is characterized by its rounded or conical crown or drooping tree shape. This small tree species has a very large taproot rooting system. The bark of the tree is brownish black in color, possesses deep fissures and ridges and rectangular checkered sections. The leaves of the plant are deciduous, simple, alternate, and entire, have smooth margins, and have are a long elliptic, drooping shape. The flowers produced by the species appear when the leaves of the plant are more than half grown between March and June. They are a yellowish-green color about half an inch in diameter, and 
exist as solitary, sessile staminate flowers in two or three-flowered tubular cymes (USDA, 2016). They are short-peduncled with four or five thick recurved lobed corollas. The fruit of the persimmon species appears between September and November once trees are at least 10 years in age, and fall to the ground during late September and through the winter. The fruit produced is a spherical berry type fruit $5 \mathrm{~cm}$ in diameter that changes from a green color to a yellow-orangered when ripe. Each berry produced contained between one and 10 brown flat seeds.

Uses of the species include being a valuable timber species, as a human food source, and as a species used in wildlife plantings in the eastern United States. The wood produced by persimmon is very hard and smooth with a very distinct texture, and these characteristics make it valuable for making golf club heads, tunery, shuttles, and other things requiring a hard material. As a food source for humans, the fruit is often dried and added to baked goods, persimmon is fermented and added to many beer hop blends, and the seeds of the species have historically been used as a substitute for coffee. There is also evidence of a medicinal value associated with the species, as it is used to treat fever, diarrhea, and hemorrhages. Many songbirds and forest mammals take advantage of the fruits of the species as well as browse on the young woody growth when included as an understory species in wildlife plantings. Because of the persimmon species deep taproot rooting system, the species is included in erosion control plantings in deep soils. The species has recently also been included in a list of woody species critically important for honey production (USDA, 2016).

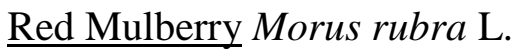

Red mulberry is a tree species belonging to the Moraceae family and is native to much of the southeastern United States (Burns and Honkala, 1990). The largest red mulberry plants are found in the Ohio River Valley (Burns and Honkala, 1990). The species thrives in moist cove environments and along flood plains where the soil is well-drained and moist along a stream. The soil orders where red mulberry is most commonly found include Alfisols, Spodosols, Ultisols, and Inceptisols (USDA, 2016). The species is included in a list of secondary successional species, and rarely exists as a pioneer species or one present during primary succession (Burns and Honkala, 1990).

Very little is known about the growth and development of the red mulberry species due to the scarcity of large stands of this species (USDA, 2016). More often, the species exists in moist 
environments scattered across the landscape as individuals in the understory. Red mulberry trees reach a height between 5 and $25 \mathrm{~m}$ on average, depending on the site conditions (USDA, 2016). It usually dies before reaching an age of 125 and can persist as an understory species for many years (Burns and Honkala, 1990). It is able to withstand periods of flooding and is shadetolerant, although is intolerant to drought and extended periods of flooding. The plant has a spreading crown, grows into a stout rounded shape with a short trunk, and has a shallow root system (Burns and Honkala, 1990). Red mulberry bark is dark, fibrous, tough, scaly and divided into half an inch thick irregular plates. Leaves of the plant are $2 \mathrm{~cm}$ long in diameter, simple, alternatively arranged, broad, lobed, pubescent, and egg-shaped (USDA, 2016). The leaves are square at the base, becoming more pointed as you move to the tip, and the tips of the leaves come to a point. Flowers of the species appear between April and May, have axillary pendulous catskins on both male and female flowers, and are more commonly dioecious but can be monoecious (USDA, 2016). Red mulberry fruit is dark purple 3-cm-long drupe that develop between and June and August from multiple drupelets from separate female flowers that grow together.

The most common reason for planting the red mulberry species is for its fruit production. Songbirds and small mammals favor the fruit produced by the species and it is therefore regarded as an important part of some species diets as well as often used as a habitat for smaller animals. Red mulberry fruit has also been included in livestock and poultry feed mixes in the past for its nutritional benefits. Fruits of this species are also commonly consumed by humans in jams, drinks, and pies. The wood produced from red mulberry plantings is durable and hard, and uses for the wood include fence posts, farm tools, furniture, and building supplies. Because of the species shallow rooting system, it does not possess soil stabilizing abilities, and subsequently is seldom included in erosion control plantings or revegetation plantings on disturbed lands.

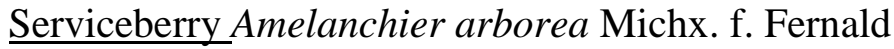

The serviceberry species belongs to the Rosaceae family and is native to the eastern United States. It is also commonly referred to as shadbush, Juneberry, or sugarplum. The species grows as a large deciduous shrub or small tree with a narrow and rounded crown, and commonly achieves a height of at least $10 \mathrm{~m}$ (Burns and Honkala, 1990). It is found in a variety of environmental conditions including swampy lowlands, rocky ridges, in forest understory, and in open woodlands and fields favoring partial shade to full sun and moist but well-drained soils (USDA, 2016). It is a very common understory species in the Appalachian forest ecosystem. It is 
most commonly referred to as a late-successional to climax forest species in the central United States' mixed-hardwood forests (Burns and Honkala, 1990).

Because the serviceberry species is able to survive in a variety of site conditions, the leaf emergence and flowering times of the species depends on the latitude of where the planting is. In the northern part of the native range of serviceberry, the plant flowers and leaves emerge at the same time during April and May, and fruits are produced in June and July (USDA, 2016). In contrast in the southern native range of the species, flowers are produced in March and the species produces fruit from June through August (USDA, 2016). Branches of the species start out as a purple color and change into a more gray hue when mature with striped vertical fissures. Leaves of the plant are simple and alternate leaves twice as long as they wide oval to oblong in shape with serrated margins. These leaves are smooth on top but have hairs on their underside. Flowers of the plant are 5-petaled, white elongated clusters on branch tips that measure 8 to 30 $\mathrm{cm}$ in length (USDA, 2016). These flowers appear before leaves emerge. Serviceberry fruits are red-purple, 6 to $12 \mathrm{~mm}$ wide, on long stalks, and contain five to 10 seeds in each (Burns and Honkala, 1990).

The serviceberry species is cultivated as pulpwood, for a wildlife food crop, as a human food source, and as an ornamental. Different cultivars are selected for their growth habit, flower size and color, as well as leaf color. Although the species produces very hard and heavy wood, it does not generally achieve a large enough size in order to be a good commercial timber supplier (Burns and Honkala, 1990). Serviceberries are an important food source for at least 40 bird species, and mammals also feed on the fruit and browse on serviceberry woody growth (USDA, 2016). Humans add serviceberries to jams and baked goods, and treat the species like an alternative to using blueberries. The species is also an important food source for the invasive Gypsy moth, and the presence of the moths can greatly reduce the growth of serviceberry. The species is also susceptible to diseases common in the eastern United States including downy serviceberry mildew and fire top.

\section{Washington Hawthorn Crataegus phaenopyrum L. f.}

This species belongs to the Rosaceae family and its natural range includes southeastern North America and the Appalachian region in USDA hardiness Zones 4 to 8 (USDA, 2016). It is also commonly called Washington thorn. The deciduous plant grows at a moderate rate in a pyramidal shape and typically reaches a height $7 \mathrm{~m}$. It is most commonly found in wooded areas 
or sunny open areas growing in a variety of soil conditions ranging from very sandy to very clayey and in the very acidic to basic pH range (USDA, 2016). Washington hawthorn can tolerate drought and semi-shade, although the plant prefers moist conditions and growing in open areas (Burns and Honkala, 1990).

Washington hawthorn is described as a hardy plant capable of withstanding a variety of conditions (IWF, 2016). Much of the success of the adaptability of this species is accredited to the dense, woody, and branching rooting system of hawthorn (USDA, 2016). Depending on the growing conditions, the species will possess either multiple or a single trunk and have dense branching (IFW, 2016). The bark produced by the species is rough and scaly, gray, and flaky (USDA, 2016). When new, woody growth emerges as either light green or reddish-brown in color, but it fades into gray with maturity (USDA, 2016). Gray, straight thorns also emerge variably on mature bark of the Washington hawthorn species that measure approximately $5 \mathrm{~cm}$ long. Leaves of the species are divided into three lobes, alternate, ovate or detate-ovate, has serrated margins, and approximately $5 \mathrm{~cm}$ long and across (USDA and IWF, 2016). Flowers of the plant appear during early spring and continue to bloom into early summer. The flowers are produced in 6-cm corymbs that contain anywhere between 15 and 50 white hermaphroditic flowers, and the individual flowers are five-petaled and odorous (USDA, 2016). The species begins heavy flowering at 3 years of age, and it takes 5 to 8 years before fruit production begins (Burns and Honkala, 1990). The fruit produced by the hawthorn species are hairless pomes, which turn from green to a reddish-orange when mature (IWF, 2016). They measure approximately $6 \mathrm{~mm}$ across and although the weight of the fruit causes the corymb in which it is produced to droop, the fruit of the hawthorn species persist on the plant through the winter.

Washington hawthorn is commonly planted in reforestation and ornamental plantings. The species produces fruit edible and liked by many forest songbirds and small mammals. The fact that the fruit remains on the tree throughout the winter time makes it an attractive option for food in the more desperate winter months. The species is also a useful nesting material for some songbird species due to its dense branching growing behavior. Hawthorn is also useful as a pollinator species. The flowers produced by the plant give off a foul odor that attracts bees, flies, wasps, butterflies, and beetles.

\section{Wild Plum Prunus americana Marshall}


Wild plum is another species belonging to the Rosaceae family (USDA, 2016). It is also commonly referred to as American plum, goose plum, and river plum. It is native to North America and its range extends over much of the continent with some exceptions being Texas, Washington, Oregon, and northern Canada. It is commonly found in the forest, in prairies, pastures, and along rivers but is overall considered to be a woodland species that grows in mixed-hardwood communities (Burns and Honkala, 1990). It is common in early to middle forest succession and occurs rarely in old-growth forests. (Burns and Honkala, 1990) The species favors deep, rich loamy soils that are acidic to mildly alkaline and sites that receive at least 40 $\mathrm{cm}$ of rain per year (USDA, 2016). The species is drought intolerant, and although semi-shade tolerant prefers full-sun conditions.

The species is usually found growing in a shrub like state although the species possess the ability to grow as a small tree with a flat-topped and irregular crown. Due to the varying growth habit of the species, the average height achieved includes a wide range in between 1 and $10 \mathrm{~m}$ with the tallest trees found in the southern most region of distribution. In the south where wild plum grows as a small tree species, it is found with one basal stem however this may or may not be present in places where the species exists as more of a shrub. The trunk of the species is short and crooked. The bark of wild plum is moderately thick with spurred branching (Burns and Honkala, 1990). The leaves of the species are deciduous, narrow and finely serrated, and between 8 and $12 \mathrm{~cm}$ (USDA, 2016). Leaves are slightly pubescent on their underside and more of a bright green on the top. Flowers produced by wild plum appear between April and May in groups of between two and five at the end of branchlets (USDA, 2016). They have five petals, are white, and described as rose-like. When these flowers are pollinated by insects, fruit begins to form. The fruit that forms are yellow or red drupes and they appear and ripen between August and September often individually or in clusters (USDA, 2016). These fruits contain one seed each.

The wild plum species is cultivated in order for its wildlife benefits, as food crop, or in a conservation planting. As a wildlife crop the fruit of the species is enjoyed by large and small forest mammals. Thickets of the species are also found to be a protective shelter for wildlife. Humans often utilize the fruits of the species in jellies and baked goods. The bark and fruit of the species are also found to have medicinal benefits including as a sedative and a tonic (Burns and Honkala, 1990). In conservation plantings the species is often selected due to their drought 
tolerance ability. They are also effective erosion control aids because of their ability to block wind and the ability of the root system to hold the soil.

\section{Experimental Design and Methods}

Williams Forestry established shrub and small tree plantings on surface mines in West Virginia. Two sites (Elk Run and Hobet) were planted in 2008 and two other sites (ICG and Fola) were planted in 2010. The study was designed as a completely randomized block design. At each site, four blocks, each measuring 0.42 ha $\left(4,160 \mathrm{~m}^{2}\right)$, were established (Figures 1 to 4 ). Two blocks were located on east-facing slopes, while the other two blocks were oriented on west-facing slopes. In each block, plots measuring $208 \mathrm{~m}^{2}$ (14.4m x 14.4m) were delineated. In each plot, one of 20 different small tree or shrub species were randomly selected and planted with 25 individuals of each species on a $2.4 \mathrm{~m}$ x $2.4 \mathrm{~m}$ spacing (Table 2). 


\section{Block 7 East}

\begin{tabular}{|r|r|r|r|r|}
\hline 14 & 1 & 18 & 2 & 3 \\
\hline 4 & 20 & 15 & 13 & 19 \\
\hline 11 & 7 & 9 & 6 & 12 \\
\hline 17 & 10 & 8 & 16 & 5 \\
\hline
\end{tabular}

\section{Block 7 West}

\begin{tabular}{|r|r|r|r|r|}
\hline 10 & 5 & 9 & 4 & 18 \\
\hline 7 & 11 & 14 & 3 & 13 \\
\hline 2 & 19 & 8 & 16 & 15 \\
\hline 1 & 6 & 20 & 17 & 12 \\
\hline
\end{tabular}

\section{Block 8 East}

\begin{tabular}{|r|r|r|r|r|}
\hline 5 & 16 & 18 & 11 & 20 \\
\hline 4 & 1 & 8 & 10 & 7 \\
\hline 15 & 14 & 17 & 19 & 12 \\
\hline 9 & 3 & 6 & 13 & 2 \\
\hline
\end{tabular}

\section{Block 8 West}

\begin{tabular}{|r|r|r|r|r|}
\hline 7 & 11 & 17 & 14 & 8 \\
\hline 2 & 10 & 13 & 12 & 4 \\
18 & 9 & 19 & 3 & 16 \\
\hline 6 & 1 & 5 & 20 & 15 \\
\hline
\end{tabular}

Figure 1. The randomized complete block design used at ICG. Numbers within plots represent different tree and shrub species (Table 4). Twenty-five individuals of each species were planted in each plot on $2.4 \times 2.4 \mathrm{~m}$ spacings. 
Block 3 East

\begin{tabular}{|r|r|r|r|r|}
\hline empty & 12 & 17 & 5 & 2 \\
\hline 18 & 4 & 19 & 15 & 1 \\
\hline 14 & 16 & 9 & 11 & 6 \\
\hline 13 & 7 & 10 & 8 & 3 \\
\hline
\end{tabular}

Block 3 West

\begin{tabular}{|r|r|r|r|}
\hline 18 & 2 & 3 & empty \\
\hline 1 & 10 & 15 & 16 \\
\hline 12 & 17 & 6 & 7 \\
\hline 19 & 4 & 9 & 11 \\
\hline 8 & 13 & 5 & 14 \\
\hline
\end{tabular}

Block 4 East

\begin{tabular}{|r|r|r|r|r|}
\hline 8 & 19 & 12 & 1 & empty \\
\hline 13 & 4 & 17 & 10 & 2 \\
\hline 5 & 9 & 6 & 15 & 3 \\
\hline 14 & 11 & 7 & 16 & 18 \\
\hline
\end{tabular}

\section{Block 4 West}

\begin{tabular}{|r|r|r|r|r|r|}
\hline 14 & 13 & 12 & 17 & 5 & 2 \\
\hline empty & 18 & 4 & 19 & 15 & 1 \\
\hline & empty & 16 & 9 & 11 & 6 \\
\cline { 2 - 6 } empty & 7 & 19 & 8 & 3 \\
\hline
\end{tabular}

Figure 2. The randomized complete block design at Elk Run. Numbers within plots represent different tree and shrub species (Table 4). Twenty-five individuals of each species were planted in each plot on $2.4 \times 2.4$ m spacings. 
Block 1 East

Block 2 East
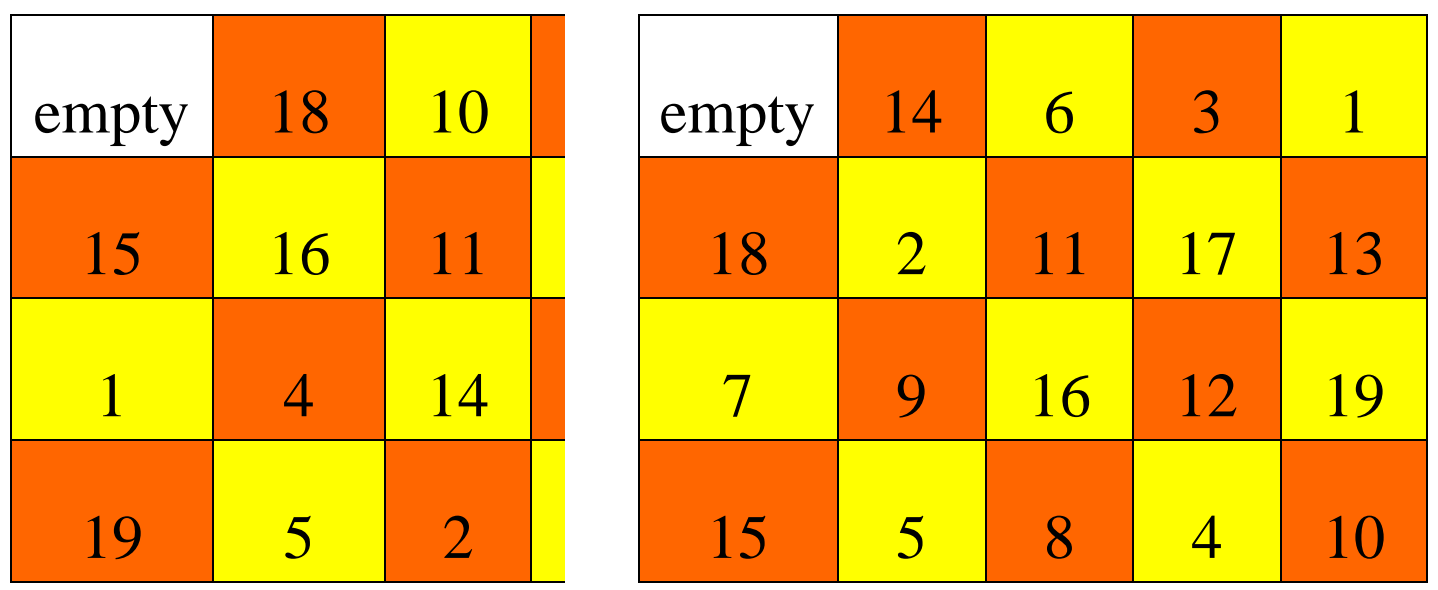

\section{Block 1 West}

\section{Block 2 West}
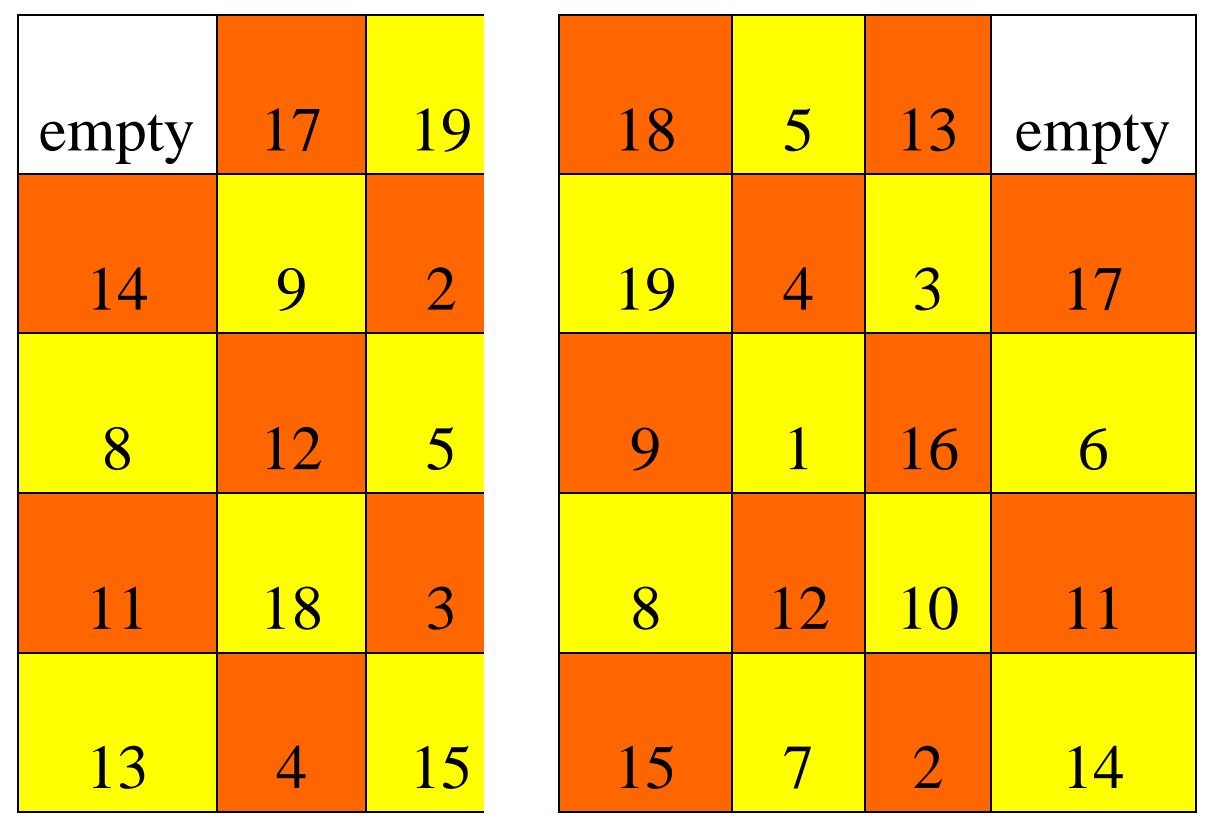

Figure 3. The randomized complete block design used at Hobet. Numbers within plots represent different tree and shrub species (Table 4). Twenty-five individuals of each species were planted in each plot on 2.4 x $2.4 \mathrm{~m}$ spacings. 
Block 1 East

\begin{tabular}{|r|r|r|r|r|}
\hline 15 & 12 & 4 & 17 & 6 \\
\hline 18 & 2 & 20 & 9 & 1 \\
\hline 16 & 10 & 7 & 5 & 3 \\
\hline 14 & 8 & 19 & 13 & 11 \\
\hline
\end{tabular}

Block 1 West

\begin{tabular}{|r|r|r|r|r|}
\hline 18 & 8 & 1 & 4 & 15 \\
\hline 3 & 14 & 19 & 11 & 9 \\
\hline 2 & 6 & 20 & 16 & 7 \\
\hline 5 & 17 & 10 & 12 & 13 \\
\hline
\end{tabular}

Block 2 East

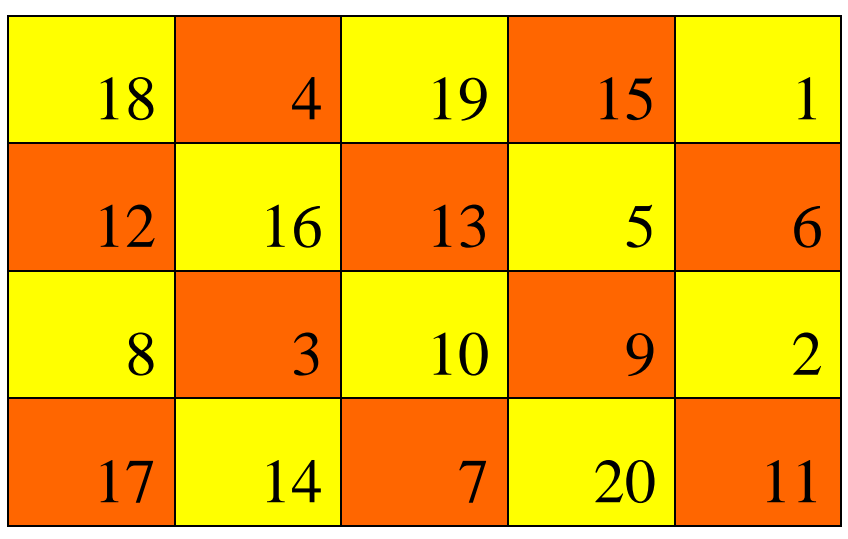

Block 2 West

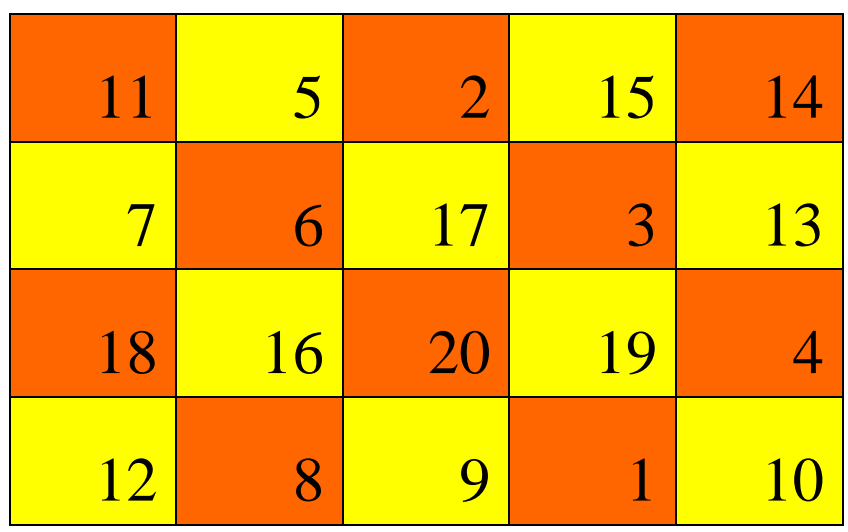

Figure 4. The randomized complete block design at Fola. Numbers within plots represent different tree and shrub species (Table 4). Twenty-five individuals of each species were planted in each plot on 2.4 x $2.4 \mathrm{~m}$ spacings.

Table 2. List of tree and shrub species used in trials. Growth forms were determined using the USDA Plants Database.

\begin{tabular}{l|ll} 
Growth Form & Common Name & Scientific Name \\
\hline Trees & American Crabapple & Malus coronaria L. \\
& Black Cherry & Prunus serotina Ehrh. \\
& Choke Cherry & Prunus virginiana L. \\
& Common Apple & Malus pumila Mill. \\
& Common Pear & Pyrus communis L. \\
& Eastern Redbud & Cercis Canadensis L. \\
& Elderberry & Sambucus Canadensis L. \\
& Flowering Dogwood & Cornus florida L.
\end{tabular}




\begin{tabular}{l|ll} 
& Pawpaw & Asimina triloba $\mathrm{L}$. \\
Persimmon & Diospyros virginiana $\mathrm{L} . \mathrm{f}$. \\
Serviceberry & Amelanchier arborea Michx. f. Fernald \\
Red Mulberry & Morus rubra $\mathrm{L}$. \\
Washington Hawthorn & Crataegus phaenopyrum $\mathrm{L} . \mathrm{f}$. \\
& Wild Plum & Prunus Americana Marshall \\
\hline Shrubs & Black Chokeberry & Aronia melanocarpa Michx. \\
& Blueberry & Vaccinium corymbosum $\mathrm{L}$. \\
& Gray Dogwood & Cornus racemose Lam. \\
& Hazelnut & Corylus avellana $\mathrm{L}$. \\
& Highbush Cranberry & Viburnum trilobum $\mathrm{L}$. \\
& Nannyberry & Viburnum lentago $\mathrm{L}$.
\end{tabular}

\section{Study Sites}

\section{8}

Elk Run and Hobet were planted in 2008, each with four blocks. They are located in the Appalachian Plateau physiographic region of southwestern West Virginia (Figure 5). The Elk Run mine is located in central Boone County, WV, and covers roughly 2,000 ha. The mine was operated by Alpha Natural Resources. The tree and shrub planting block locations at Elk Run are located at approximately $38^{\circ} 04^{\prime} 20^{\prime}$ N, 81 43’27” W (Figure 6). The Hobet mine near Madison, WV, covers approximately 5,000 ha in Boone and Lincoln counties. The mine was operated by several companies: Hobet, Arch, Magnum, and now is held by the Virginia Conservation Legacy Foundation. The Hobet block locations are located at approximately $38^{\circ}$ $07^{\prime} 38.76$ " $\mathrm{N}, 81^{\circ} 52^{\prime} 37.83^{\prime}$ ' W and are a part of the S-0128-78 permit in the Long Branch area of the mine (Figure 7). 


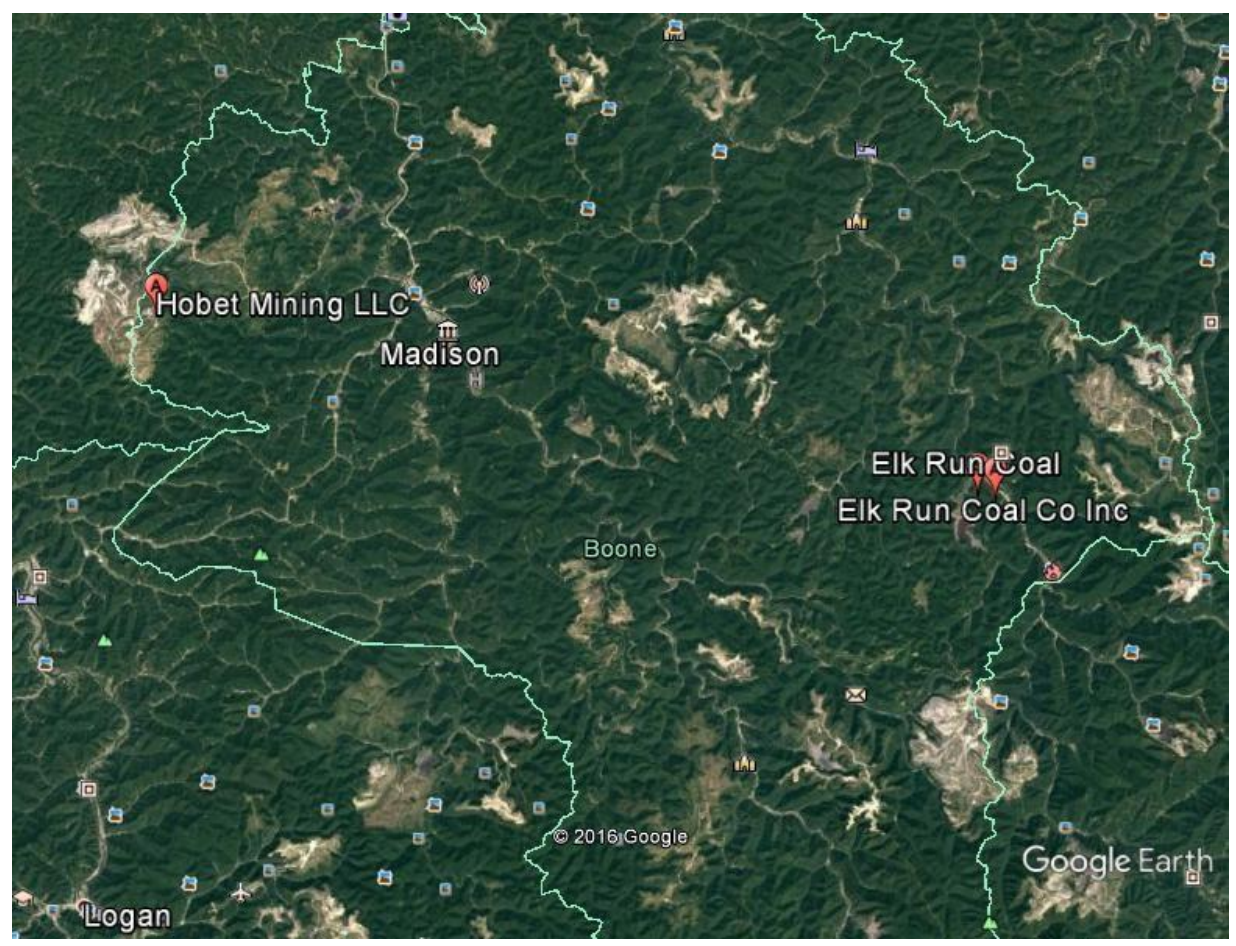

Figure 5. The Appalachian Plateau physiographic region in Boone County of southwestern West Virginia where the Hobet and Elk Run Mine are located.

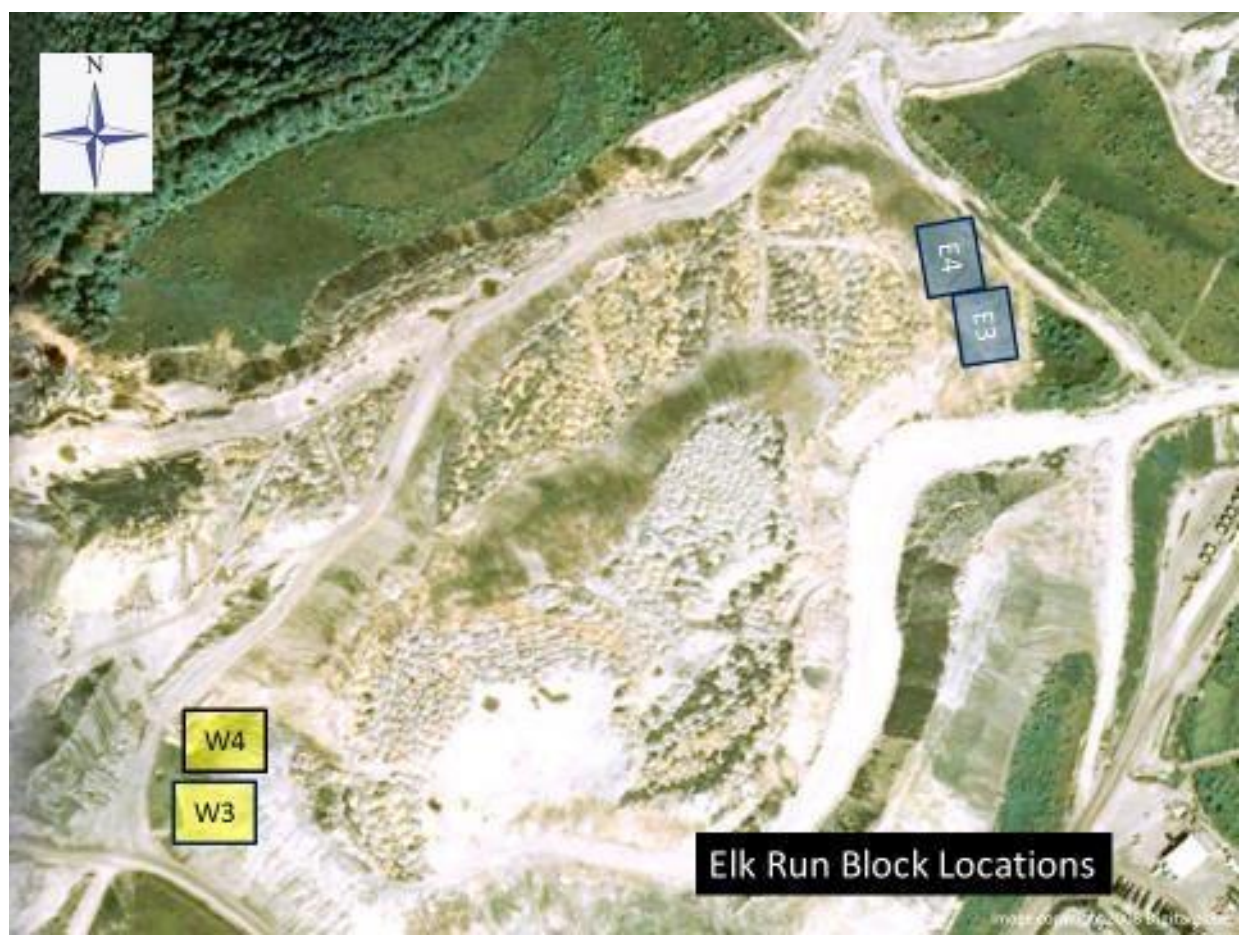

Figure 6. Satellite image of research block locations on Elk Run Mine, Boone County, WV in 2008. 


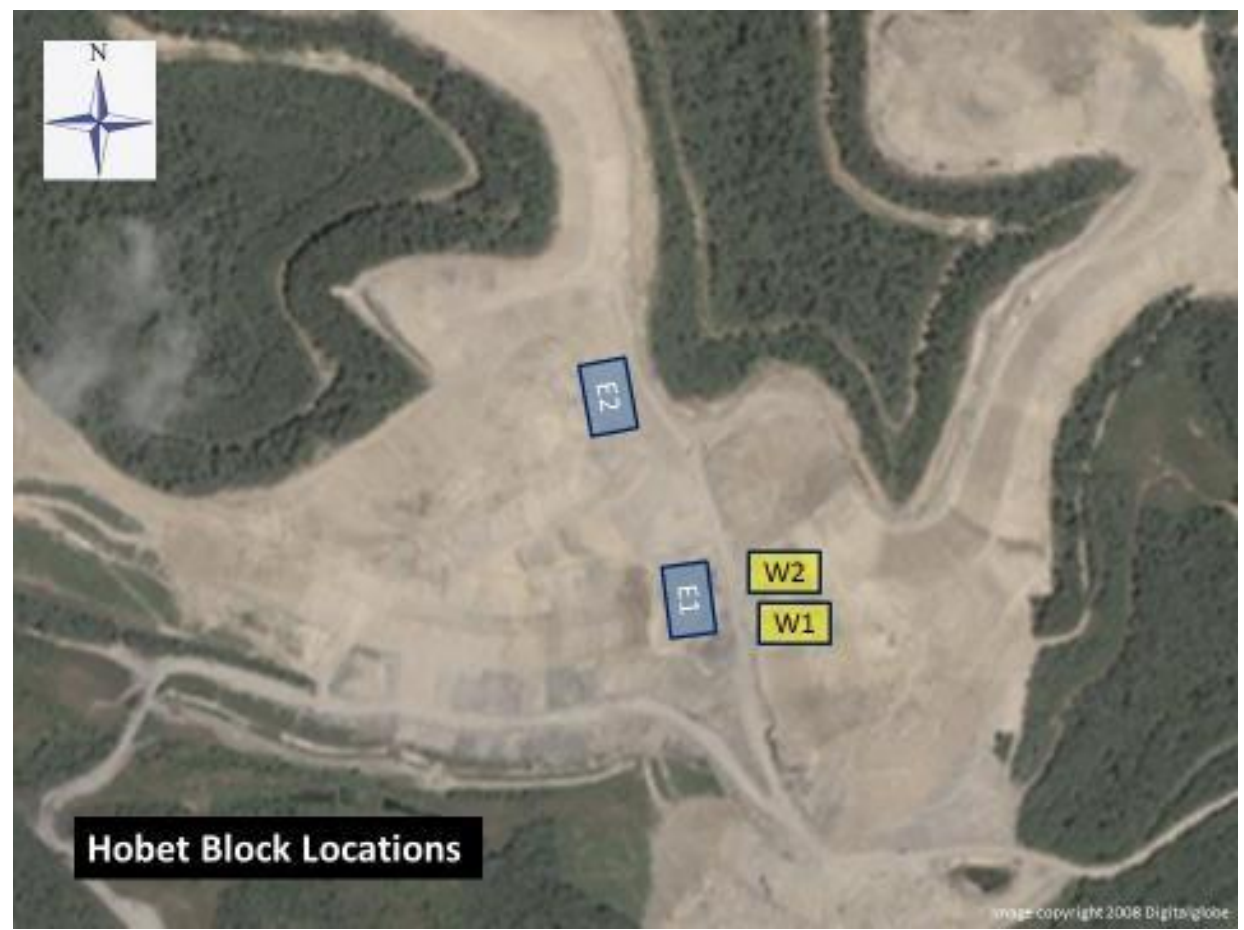

Figure 7. Satellite image of research block locations on Hobet Mine, Boone County, WV in 2008.

The mine soil on the research area at Elk Run is characterized by a mixed brown and gray sandstone substrate. The blocks were located on slopes that averaged 14 and 20 percent. The research plots had a wide range of ground cover from 0 to 100 percent. There was evidence of gully erosion, particularly where the ground was bear with little to no vegetative cover. Common groundcover species that existed at Elk Run include birdsfoot trefoil (Lotus corniculatus L.), orchardgrass (Dactylis glomerata L.), tall fescue (Schedonardus arundinacea Schreb.), perennial ryegrass (Lolium perenne L.), sericea lespedeza (Lespedeza cuneate Dum. Cours.), knotweed (Polygonum aviculare Siebold \& Zucc.), white aster (Symphyotrichum ericoides L.), casper spurge (Euphorbia lathyris L.), and broomsedge bluestem (Andropogon virginicus L.). In areas where the groundcover was good, survival of woody growth was poor. Natural encroachment of woody plants onto the mine site was observed from the surrounding dense forest and those species commonly found encroaching included autumn olive (Elaeagnus umbellata Thumb.), black locust (Robinia pseduoacacia L.), sycamore (Platanus occidentalis L.), and princess trees (Paulownia tomentosa Thumb.).

A mix of brown and gray sandstone characterized the Hobet mine soil with many rock fragments ranging in size from small pebbles to cobble size. The site had extensive gully erosion, 
due to both the steep slope and absence of sufficient herbaceous cover to slow water runoff. The average slope of the area was between 18 and 25 percent depending on the research block. The groundcover existing in the research area ranged from having a $0 \%$ cover to a $100 \%$ ground cover. The most common species found in the area included birdsfoot trefoil, orchardgrass, tall fescue, perennial ryegrass, sericea lespedeza, knotweed, white aster, caper spurge, and broomsedge bluestem. The east facing research blocks (E1 and E2) at Hobet were partially bulldozed after establishment. Forest encroachment from the existing forest that surrounds the research blocks was starting to occur. There is some natural colonization by black locust, autumn olive, princess trees, and sycamore species into the plot.

\section{0}

ICG and Fola mine sites were planted each with four blocks in 2010. These sites are also located in the Appalachian Plateau physiographic region of WV (Figure 8). ICG is located in Fayette and Webster Counties and the mine was operated by several companies over the years: Shell, Evergreen, and International Coal Group. The mine covers approximately 2,000 ha. The two east-facing ICG blocks are located at approximately $38^{\circ} 26^{\prime} 08.45^{\prime}$ N, $80^{\circ} 37^{\prime} 05.74$ ” W, and the two west-facing ICG blocks are located at approximately $38^{\circ} 27^{\prime} 21.95^{\prime \prime} \mathrm{N}, 80^{\circ} 36^{\prime}$ 36.96" W (Figure 9). These research blocks are a part of permit number S-235-76. Blocks 7W and $7 \mathrm{E}$ were established in a Clarion shale substrate. This mine soil consists of numerous shale channers or small chips that absorb thermal radiation, thereby making the surface very hot during summer. This site had slopes ranging from 25 to 30 percent. The mine soil produced almost no herbaceous cover, which allowed the planted woody growth to grow free from herbaceous cover competition. The most common herbaceous species that occurred included sericea lespedeza, knotweed, caper spurge, birdsfoot trefoil, Queen Anne's lace (Daucus carota L.), coltsfoot (Tussilago farfara L.), thistle (Onopordum acanthium L.), and yarrow (Achillea millefolium L.). There was an established forest surrounding both 7W and 7E blocks and encroachment by autumn olive, princess trees, and black locust was apparent. The other two research blocks at ICG were planted in a mixed brown and gray sandstone mine soil. The slopes of these remaining blocks was not as steep as 7E and 7W and there was more competition from both herbaceous and woody plant types. The common encroaching species here were the same as those in the other two blocks. 


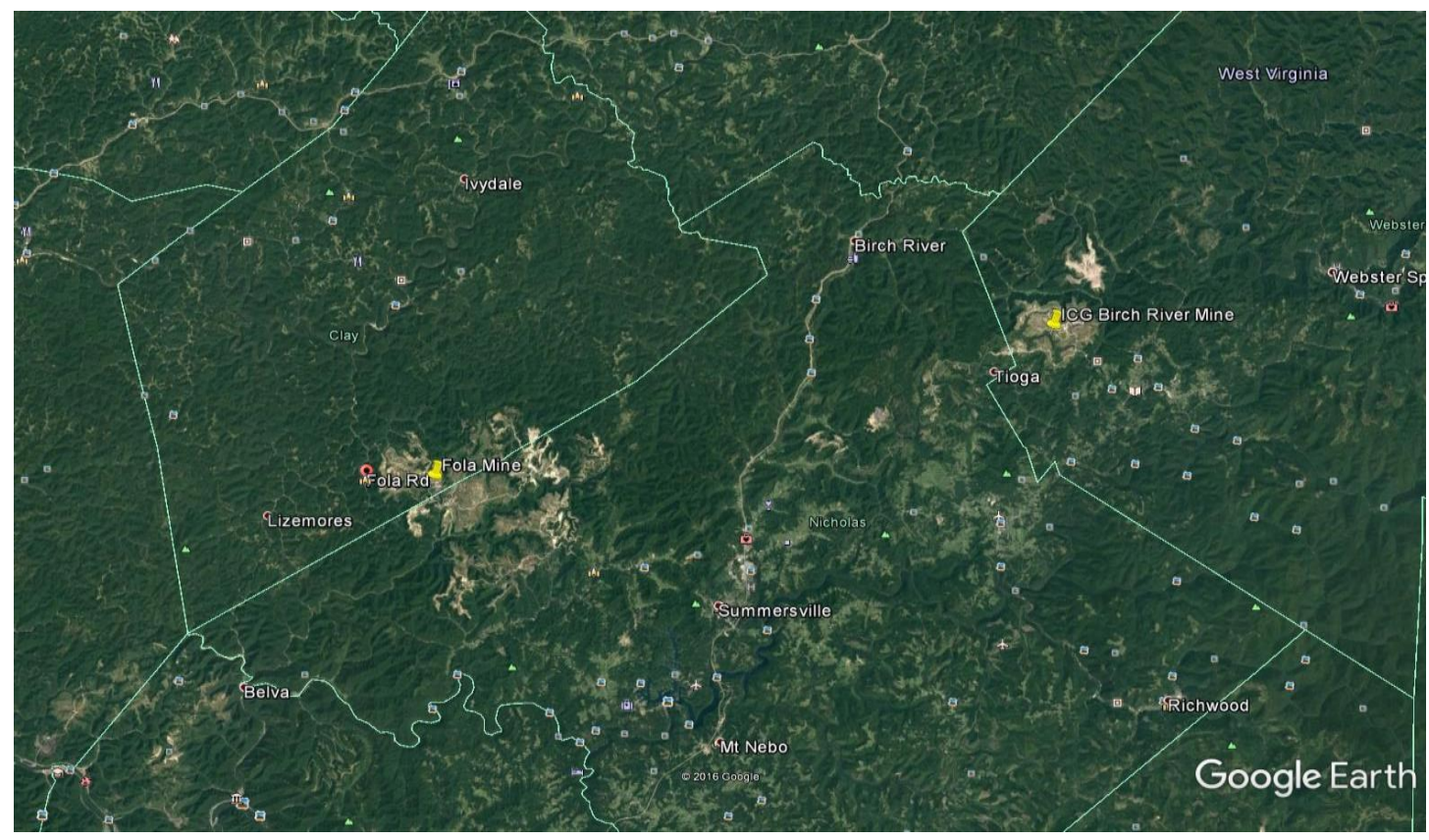

Figure 8. The Appalachian Plateau physiographic region in Clay, Nicholas, and Webster Counties of West Virginia where the Fola and ICG Mine are located.

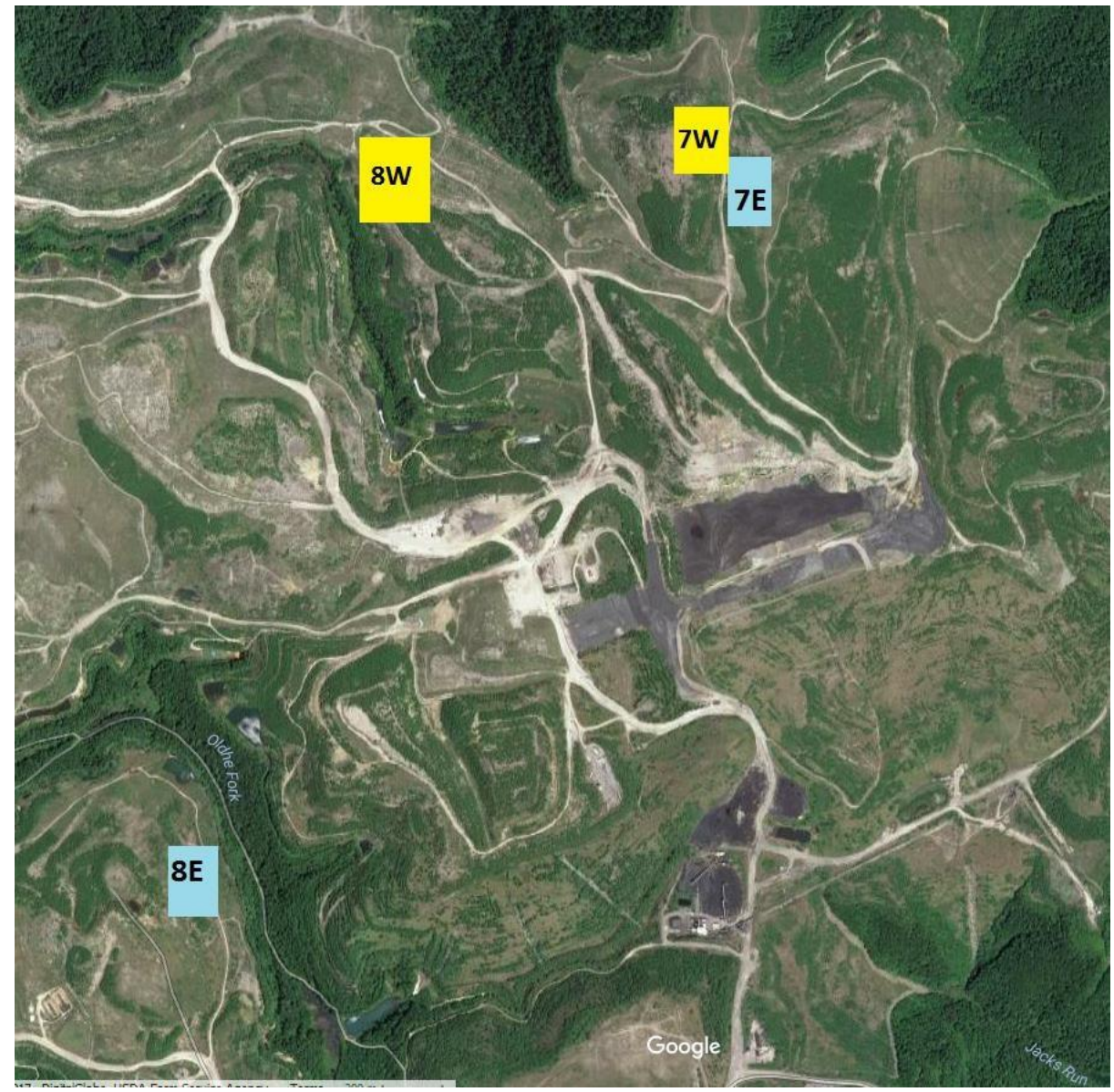

Figure 9. Satellite image of research block locations on ICG Mine, Webster and Nicholas County, WV in 2010 
Fola is located in Clay County and was owned and operated by Fola Coal Company and then by Consolidation Coal Company. Fola covers approximately 4,000 ha. The research blocks are located at approximately $38^{\circ} 35^{\prime} 24.66^{\prime \prime} \mathrm{N}, 81^{\circ} 08^{\prime} 94.19^{\prime \prime} \mathrm{W}$ (Figure 10). Due to the high and dense vegetation growing at the site in 2015, only two of the four research blocks could be found. One block, F2W, is close to a road and has an average slope of 24 percent. The mine soil of this block is a mixed brown and gray sandstone materials with gray being more dominant, which included numerous large rocks on the surface. The very dense and almost impassable vegetation was comprised of sericea lespedeza and bramble (Rubus spp.), Goldenrod (Solidago canadensis), and broomsedge bluestem along with volunteer woody growth from black locust and autumn olive. The east-facing block had less percent herbaceous groundcover than the westfacing block. Ground cover percentages were generally less than $100 \%$ and included large bare patches of ground. Common herbaceous and woody species that occupied the area included the same species found on the other block. 


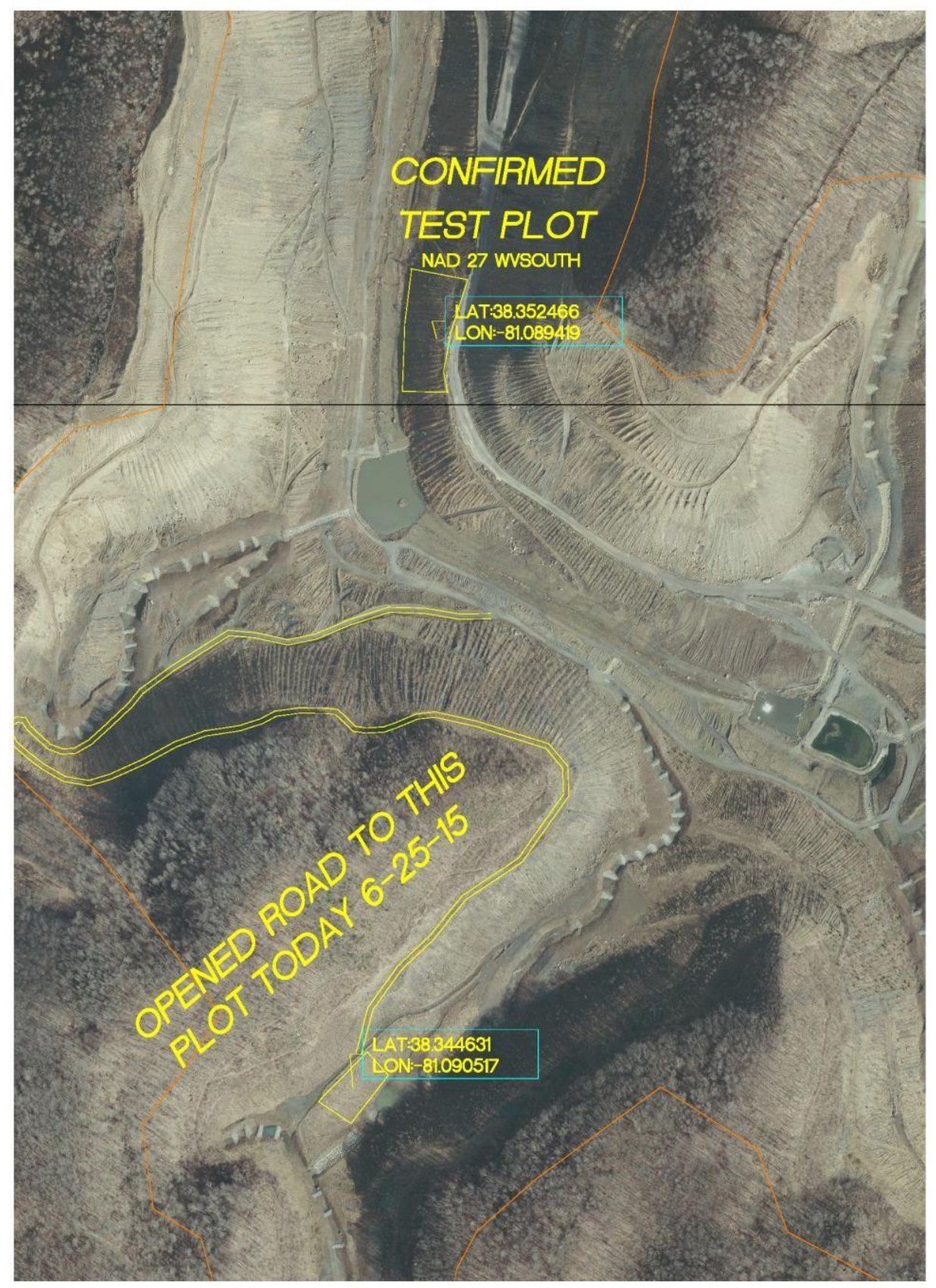

Figure 10. Satellite image of research block locations on Fola Mine, Clay County, WV in 2010.

\section{Tree-planting and Early Measurements}

All seedlings were planted by workers of Williams Forestry as bareroot 1-0 stock and were kept refrigerated at approximately $36^{\circ} \mathrm{F}\left(2.2^{\circ} \mathrm{C}\right)$ with the roots contained in bags until the day of planting, with the exception of the highbush blueberry, which were transplanted from containers. Approximately 300 of each species were purchased each year even though only 200 would be 
used for the study. Bareroot seedlings were separated into bundles of 25 with the largest and smallest individuals being culled during separation, so that moderately-sized individuals would be planted in the study plots. The bagged seedlings were removed from refrigeration the morning of planting and the roots of all bare root seedlings were dipped in a water and TerraSorb ${ }^{\mathrm{TM}}$ suspension. The TerraSorb ${ }^{\mathrm{TM}}$ suspension was used to protect the roots from dessication during the time between storage in the planting bags and planting. Root pruning was kept to a minimum and was only allowed when root length exceeded blade length $(>20 \mathrm{~cm})$. Each planted seedling was marked with a colored pin flag to aid in subsequent location and measurement.

\section{8 and 2010 Data Collection}

Blocks were assigned a number followed by a letter, which corresponds to the aspect of the block. For example, block $2 \mathrm{~W}$ would represent block 2, west-facing. Every seedling within a species plot was assigned a number (from 1 to 25 ) so that individuals could be tracked for survival, growth, and health over time.

A survey of all planted trees and shrubs was conducted for survival, growth, and health at the end of the first growing season. In reclamation plantings, the first year often produces the highest woody plant mortality, with less mortality in year two and beyond (Burger et al., 2005).

Height was measured from ground level to the height of the highest living tissue, and was recorded to the nearest $\mathrm{cm}$ using a standard meter stick. As seedlings were planted on a slope, the meter stick was placed on the higher side of the hill for all measurements. When an individual suffered from stem dieback, the height measurement was taken at the highest point of the stem that was determined to be living at the time of measurement. Diameter was measured at ground level, using digital calipers, and was recorded to the nearest millimeter. Only the dominant stem was measured for height and diameter on individuals exhibiting multiple stems. Other measured variables included herbivory, dieback, chlorosis, etc. These measurements were done by workers employed by Williams Forestry. The data collected during the first year after planting were made available for analysis in this study.

\section{5 and 2016 Data Collection}

A survey of all trees and shrubs was conducted in 2015 and 2016. Survival, growth, and health of each individual was assessed. Due to the increased size and growth of the trees, modifications of the sampling techniques from the original sampling design in 2008-2010 were 
adopted. To better assess the height achieved by each individual plant, height was measured using a meter stick and read to the nearest 0.1 meter instead of $\mathrm{cm}$. Diameter was taken at $2.5 \mathrm{~cm}$ above ground level where possible. With multi-stemmed shrubs and trees, crown cover was measured instead of a single stem diameter. Crown cover consisted of measuring the average spread of the shrub to the nearest $\mathrm{cm}$. In the field, this consisted of obtaining the shortest and longest values of spread and averaged.

In addition to tree and shrub measurements, soil sampling was also performed in order to correlate the success of the species with mine soil properties. For this, at three random locations within each plot, a soil sample was collected to a depth of $15 \mathrm{~cm}$. These three samples were composited into one sample and used as a representative sample for each plot. Therefore, 20 soil sample composites were collected for each block and 80 samples were collected per site for a total of 320 samples for analysis.

Herbaceous ground cover was also estimated to allow an assessment of competition and its effect on tree and shrub survival and growth. Ground cover was evaluated visually using a $1 / 4 \mathrm{~m}^{2}$ quadrat in the field. The quadrat was randomly placed in three places in each species plot. At each of these three points, the species occupying the space in the quadrat were recorded as well as their percent cover. Using this information, herbaceous cover competition was correlated to species success.

Samples were dried, weighed and sieved into coarse and fine fractions (2-mm sieve). The percentage of fine material and coarse material for each soil was determined. The soil fine fraction was analyzed for chemical properties including soil $\mathrm{pH}$ using a 1:1 soil:water ratio, soluble salts (as electrical conductivity using 2:1 soil:water ratio). Phosphorus (P), potassium $(\mathrm{K})$, magnesium $(\mathrm{Mg})$, calcium $(\mathrm{Ca})$, sodium $(\mathrm{Na})$ and other elements $(\mathrm{Fe}, \mathrm{Al}, \mathrm{Mn}, \mathrm{Zn}, \mathrm{Cu}$, and $\mathrm{Ni}$ ) were analyzed using the Mehlich 1 extraction solution. From this chemical analysis, soil properties were correlated to shrub and tree growth through regression analyses and principle component analysis.

\section{Statistical Analysis}

The survival data was left-skewed and transformations did not work well to correct the lack of normality in the data. Therefore, the parametric methods could not be used, rather, the data was treated as categorical and Mantel-Haenszel frequency analysis was used. Chi-square analysis of 
survival by species was done to compare survival by year (2015 and 2016). The effect of aspect on survival was explored through frequency analysis (Chi-square) for all species combined and separately by species. Chi-square frequency analysis was also used to quantify the association of site and survival status with all species and aspects combined, and additionally was completed separately by species and by aspect. Repeated frequency analysis using the ridit scores of the Mantel-Haenszel procedure measuring the nonzero correlation of age and survival was done to test the effect of age on survival, utilizing the first year after establishment and the ages 7 and 8 for the older plots (Elk Run and Hobet), and 5 and 6 for the younger plots (Fola and ICG).

To test the effect of age on plant height, a repeated measures ANOVA was done. Due to the irregular timing of sampling, the ANOVA was adjusted to account for the irregular spacing between sampling times. Two separate ANOVAs were used for two different age site groups, Elk Run with Hobet and Fola with ICG so that no site had an advantage and was only compared against the site of the same age. Age was used as the repeated measure factor in a model with effect of age, site, aspect, and their interactions as independent variables on height as a response. After finding significant main effect(s) or interaction(s) in the repeated measure ANOVAs, Tukey-Kramer adjustments were applied to multiple comparisons to control type 1 errors.

In order to relate site properties (physical and chemical soil properties) with average height, a stepwise regression, principle component analysis and principle component regression were used. First, stepwise regression was performed to regress the height of individual species on all site properties. The two different aged site groups were analyzed separately, with regression only performed on sites that were the same age. Selection criteria for any variable entering the multiple regression model was 0.3 and the criteria for staying in the model was 0.05 . In order to analyze all sites (older and younger) by principle component analysis, the average height of each plot and species was normalized using the difference between minimum and maximum average height. Specifically, for each species, the minimum height minus $0.01 \mathrm{~m}$ was subtracted from each average height measurement. Then the new height was multiplied by 100 and divided by the new maximum height (maximum height minus the minimum height). In this final step, the normalized height of each species and plot is expressed as a percentage of the maximum height for the respective species.

$$
\text { Normalized Height }=\underline{(\text { original height }-\min )(100)} \quad \underline{(\text { new ind } . \text { height })(100)}=
$$


Once height was normalized, all sites could be used in one analysis. A principle component analysis (PCA) was utilized to find the uncorrelated site variables among all 16 physical and chemical variables. The principle component analysis produced a number of principle component groups with different contributions from each input variable in the PCA. Those variables with the highest eigenvector value (greater than 0.3) represented the variables with the most contribution to each principal component. Principle component regression (PCR) was a next step, where the PCs and later, the corresponding variables selected in the PCA were utilized to predict the normalized height.

Statistical analyses were performed using SAS 9.4 software (SAS®, Version 9.4, SAS Institute Inc., Cary, NC, Copyright (C2002-2012). Significance criterion alpha for all tests was 0.05 .

\section{Results}

\section{Soil Properties}

Soil conditions were very variable across the four sites included in this study (Table 3). Elk Run and Fola had a lower average slope (around 15\%) compared to about 22\% at Hobet and ICG. It was observed that some soils were more compacted than others, and the differences were largely related to slope. Compaction was not measured on these sites with probes or meters, but appeared to be lower on those sites with steeper slopes based on walking and extracting soil samples. The assumed lower compaction at Hobet and ICG could have influenced species growth. But as noted, Hobet generally had the lowest average heights for most of the shrub and tree species compared to the other sites, and Elk Run had the highest average heights.

The sites had different average soil $\mathrm{pH}$ values, which impacted the growth of the planted species. ICG and Elk Run soils had the highest pH values (above 6.0), while Fola and Hobet soils were below 5.0 (Table 3). Soluble salts were very high at Fola, being three times higher than the average EC values at other sites. The low $\mathrm{pH}$ condition of the soil at Fola probably allowed for solubilization of elements, which contributed to the high EC levels at that site. ICG had the lowest percent fines at 58\%, while the other sites had higher levels. A higher level of percent fines usually improves water relations and nutrient holding capacity. 
Table 3. Average values for site parameters for soils at each site measured in 2015.

\begin{tabular}{|l|c|c|c|c|}
\hline & \multicolumn{4}{|c|}{ Sites } \\
\hline Soil Properties & Elk Run & Hobet & ICG & Fola \\
\hline Average slope (\%) & 14 & 22 & 23 & 16 \\
\hline $\begin{array}{l}\text { Average } \\
\text { Groundcover (\%) }\end{array}$ & 27 & 39 & 50 & 67 \\
\hline Fines (\%) & 74 & 82 & 58 & 66 \\
\hline Average $\mathrm{pH}$ (range) & 6.4 & 4.5 & 7.5 & 3.4 \\
& $(4.9-7.9)$ & $(3.9-6.2)$ & $(7.3-7.6)$ & $(3.3-3.5)$ \\
\hline $\mathrm{EC}(\mu \mathrm{S} / \mathrm{cm})$ & 85 & 73 & 84 & 261 \\
\hline $\mathrm{K}$ & 0.11 & 0.06 & 0.16 & 0.12 \\
\hline $\mathrm{Ca}$ & 7.21 & 0.06 & 0.16 & 0.12 \\
\hline $\mathrm{Mg}$ & 2.56 & 0.28 & 0.16 & 0.12 \\
\hline $\mathrm{P}$ & 36.71 & 12.58 & 36.30 & 6.48 \\
\hline $\mathrm{Al}$ & 62.72 & 71.77 & 35.98 & 235.60 \\
\hline $\mathrm{Zn}$ & 1.99 & 0.94 & 4.79 & 1.85 \\
\hline $\mathrm{Ni}$ & 0.80 & 0.31 & 0.78 & 1.46 \\
\hline $\mathrm{Cu}$ & 1.79 & 0.47 & 2.96 & 2.92 \\
\hline $\mathrm{Mn}$ & 38.91 & 13.82 & 47.12 & 10.67 \\
\hline $\mathrm{Fe}$ & 0.04 & 0.02 & 0.03 & 0.04 \\
\hline $\mathrm{Na}$ & 0.04 & 0.02 & 0.03 & 0.04 \\
\hline
\end{tabular}

The site with the lowest $\mathrm{pH}$, low percent fines value, and highest EC was the Fola site, which should have made this site the poorest in terms of shrub and tree growth. But Fola generally had better average growth for planted species than Hobet. The ICG site was found to have the highest $\mathrm{pH}$ value overall and the lowest percent fines. ICG had a unique mine soil material with a mix of broken sandstone and Clarion shale materials, and was characterized by shale channers that were found in many places on the surface. This material also inhibited the amount of herbaceous competition growing on the site (Table 3). The Hobet site had a low pH of 4.5, and the largest percentage of fines. Gully erosion was a common occurrence noted at this site due to the fine material in soils and steep slopes. Elk Run had the largest $\mathrm{pH}$ range. This substrate was similar to that of Hobet, and gully erosion and bare soil conditions were common sights on the research blocks.

Other chemical properties of the soils at the four different sites were also variable (Table 3). Elk Run had the highest concentrations of calcium, magnesium, and phosphorus. ICG had the highest amount of potassium, zinc, copper, and manganese. Fola had the most competing groundcover, and had the highest concentrations of aluminum and nickel. The Hobet site did not possess any of the highest concentrations of any chemical parameter, but generally had the 
lowest concentration of many chemicals out of any of the sites including potassium, calcium, phosphorus, zinc, nickel, copper, iron, and sodium.

\section{Tree and Shrub Survival}

The four sites included in the study were planted at different times: the older plants were established in 2008 at Elk Run and Hobet, and younger plants were established in 2010 at Fola and ICG. Due to the two-year difference in survival and growth times, survival after 8 years could be very different from survival after only 6 years, so these sites were separated into older and younger plantings. There were also 14 trees and six shrubs. To make the figures more readable, the species figures were generally separated into three figures, the first seven trees (alphabetically A-E), the second seven trees (alphabetically F-W), and the six shrubs on the third figure.

No significant difference was found between the survival percentages between 2015 and 2016 ( $\mathrm{p}=0.51$, Table 4). Due to the insignificant difference between 2015 and 2016 data, the 2016 data were chosen to represent survival percentages in further detail.

Table 4. Average survival values for all species in 2015 and 2016.

Species

American Crabapple

Black Cherry

Black Chokeberry

Blueberry

Chokecherry

Common Apple

Common Pear

Eastern Redbud

Elderberry

Flowering Dogwood
$\%$ Survival 2015

41

52

56

31

44

41

38

48

27

11
\% Survival 2016

40

55

56

30

44

41

47

45

27

10 


$\begin{array}{ccc}\text { Gray Dogwood } & 45 & 44 \\ \text { Hazelnut } & 51 & 50 \\ \text { Highbush Cranberry } & 47 & 47 \\ \text { Nannyberry } & 53 & 52 \\ \text { Pawpaw } & 9 & 9 \\ \text { Persimmon } & 37 & 37 \\ \text { Red Mulberry } & 41 & 41 \\ \text { Serviceberry } & 47 & 44 \\ \text { Washington Hawthorn } & 57 & 54 \\ \text { Wild Plum } & 45 & 44\end{array}$

TOTAL

Significant differences in survival were found among the different species across sites, and this proved to be highly significant ( $\mathrm{p}$ <0.0001) (Figures 11 A-C, Table 5). Clearly, some species established and survived better than others due to the individual's health and quality at planting, the stresses the individual plants experienced in the soils and environment at each site and block, and to the differences in the species' adaptation to the stressful conditions of mine soils. A comparison will be made among species about first year survival and then to subsequent survival after 6 or 8 years on these sites. For the entire study including all species and all sites, the survival was $40 \%$ (Table 4 ).

The best performing species overall was black chokeberry, having 56\% survival (Table 5). Four other species had survival percentages at or above 50\% including black cherry (55\%), Washington hawthorn (54\%), nannyberry (52\%), and hazelnut (50\%). The most median survival percentages for species in this study were between 40 and 50\%. The 10 species in this group included common pear (47\%), highbush cranberry (47\%), eastern redbud (45\%), chokecherry (44\%), gray dogwood (44\%), serviceberry (44\%), wild plum (44\%), common apple (41\%), red mulberry (41\%), and American crabapple (40\%). Blueberry and persimmon had survival percentages between 30 and 40\%. Elderberry was the only species between 20 and 30\% survival. 
Two species in the study had survival percentages at or below $10 \%$, flowering dogwood (10\%) and pawpaw $(9 \%)$.

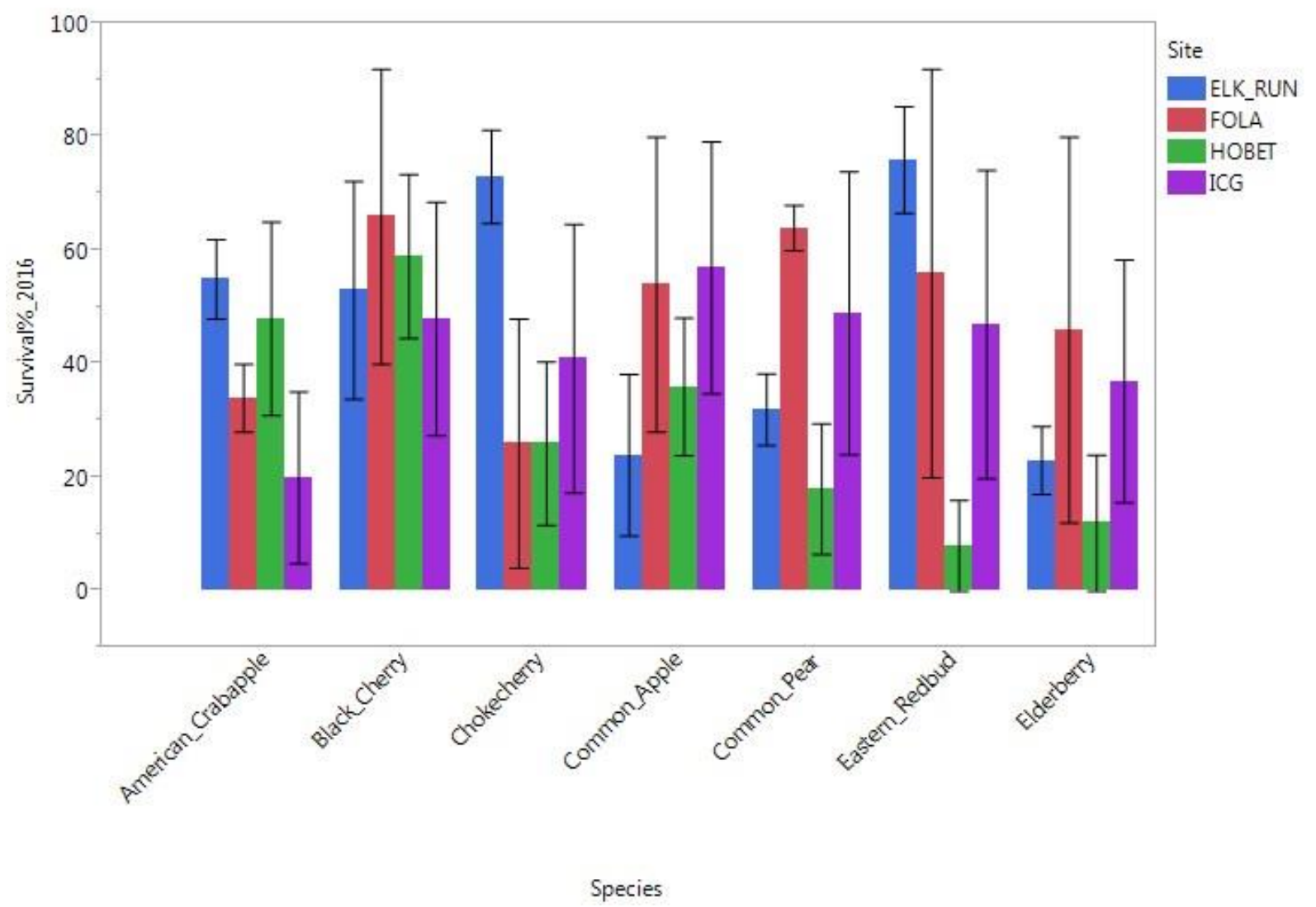

Figure 11A. Average survival percentages of seven tree species (A-E) by site in 2016 with error bars. 


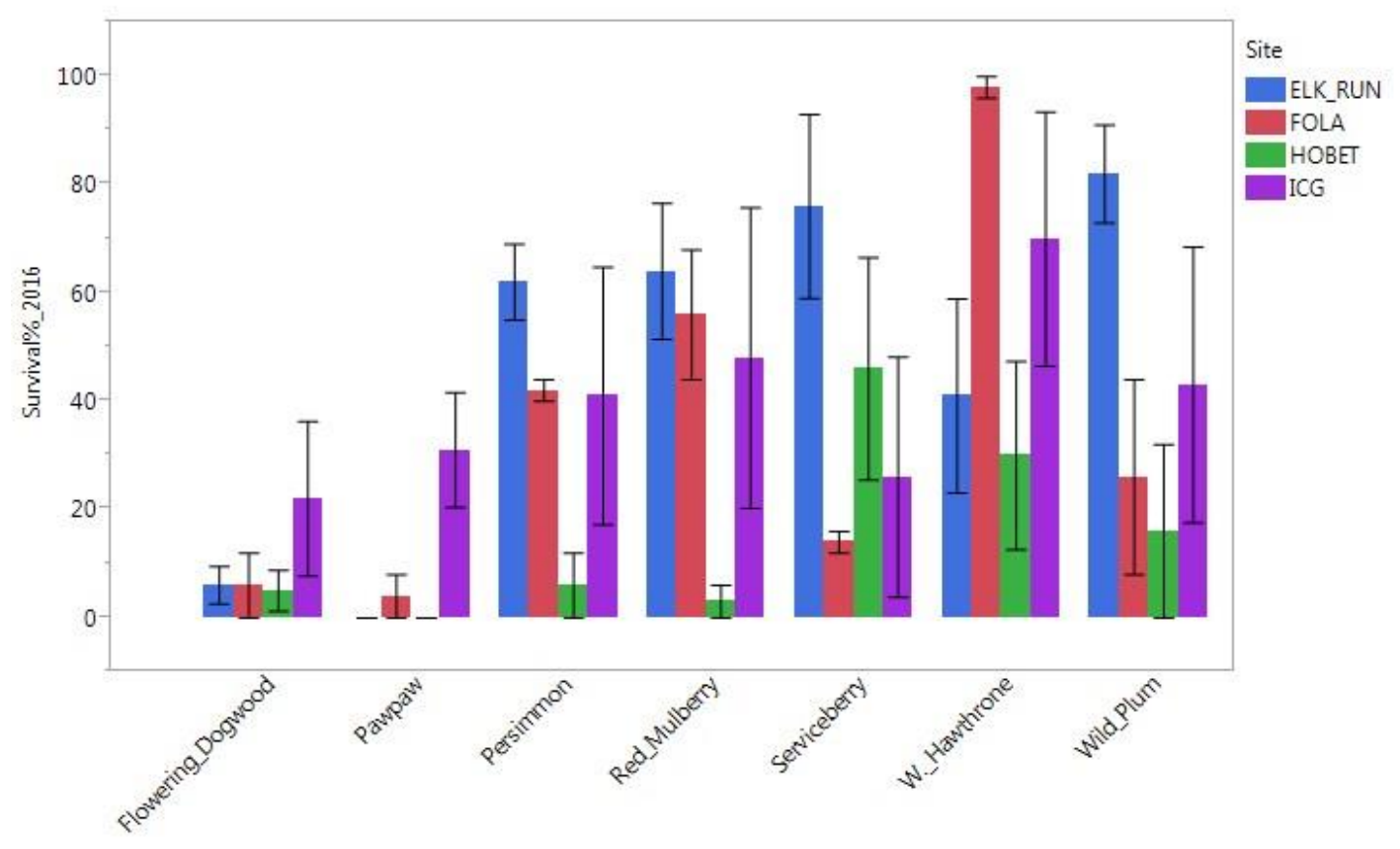

Species

Figure 11B. Average survival percentages of seven tree species (F-W) by site in 2016 with error bars.

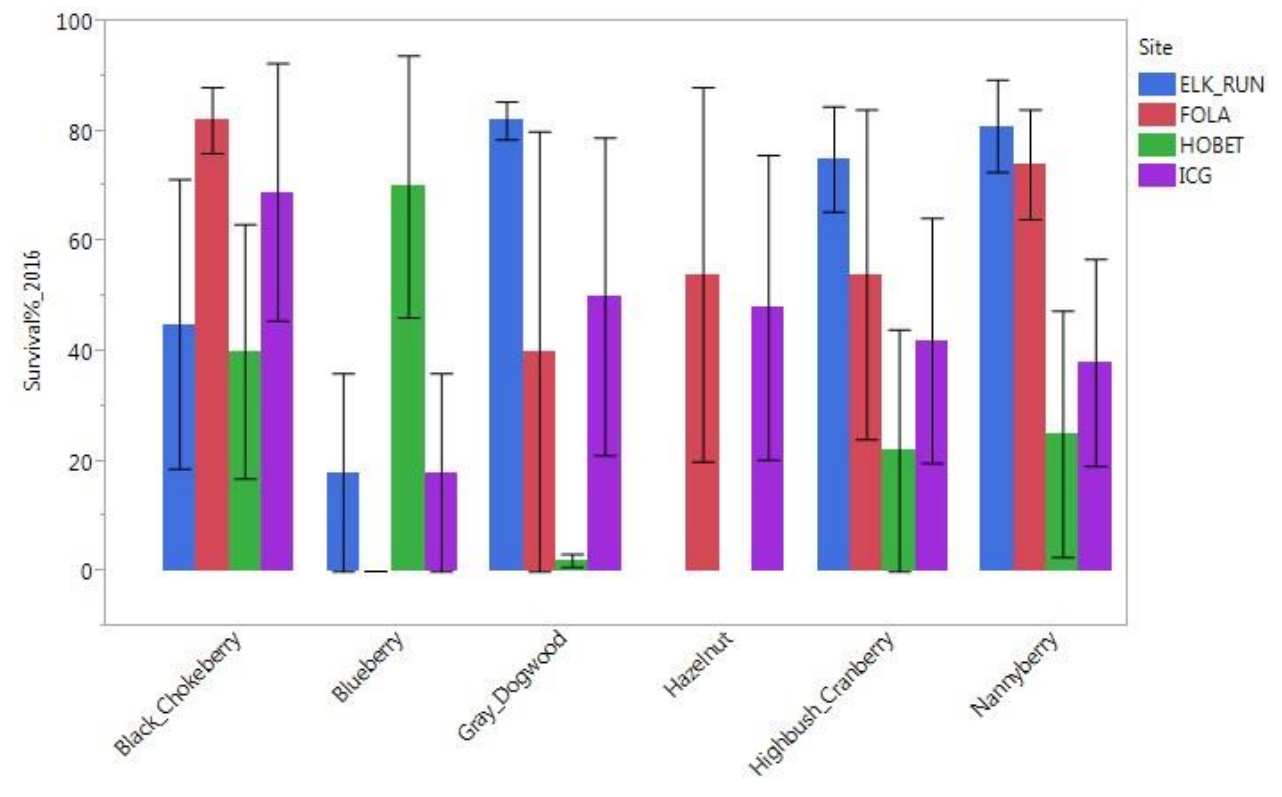

Species

Figure 11C. Average survival percentages of shrub species by site in 2016 with error bars. 
Table 5. Species survival by site. The Chi-square probability of significant difference between sites is shown.

\begin{tabular}{|c|c|c|c|c|c|c|}
\hline Species & Elk Run & Hobet & ICG & Fola & $\begin{array}{l}\text { Chi-Square p- } \\
\text { value }\end{array}$ & Average \\
\hline $\begin{array}{l}\text { American } \\
\text { Crabapple }\end{array}$ & 55 & 48 & 20 & 34 & $<0.0001$ & 40 \\
\hline Black Cherry & 53 & 59 & 48 & 66 & 0.17 & 55 \\
\hline $\begin{array}{c}\text { Black } \\
\text { Chokeberry }\end{array}$ & 45 & 40 & 69 & 82 & $<0.0001$ & 56 \\
\hline Blueberry & 18 & 70 & 18 & 0 & $<0.0001$ & 30 \\
\hline Chokecherry & 73 & 26 & 41 & 26 & $<0.0001$ & 44 \\
\hline $\begin{array}{l}\text { Common } \\
\text { Apple }\end{array}$ & 24 & 36 & 57 & 54 & $<0.0001$ & 41 \\
\hline Common Pear & 32 & 18 & 49 & 64 & $<0.0001$ & 37 \\
\hline $\begin{array}{l}\text { Eastern } \\
\text { Redbud }\end{array}$ & 76 & 8 & 47 & 56 & $<0.0001$ & 45 \\
\hline Elderberry & 23 & 12 & 37 & 46 & $<0.0001$ & 27 \\
\hline $\begin{array}{l}\text { Flowering } \\
\text { Dogwood }\end{array}$ & 6 & 5 & 22 & 6 & $<0.0001$ & 10 \\
\hline $\begin{array}{c}\text { Gray } \\
\text { Dogwood }\end{array}$ & 82 & 2 & 50 & 40 & $<0.0001$ & 44 \\
\hline Hazelnut & N/A & N/A & 48 & 54 & 0.56 & 50 \\
\hline $\begin{array}{l}\text { Highbush } \\
\text { Cranberry }\end{array}$ & 75 & 22 & 42 & 54 & $<0.0001$ & 47 \\
\hline Nannyberry & 81 & 25 & 38 & 74 & $<0.0001$ & 52 \\
\hline Pawpaw & 0 & 0 & 31 & 4 & $<0.0001$ & 9 \\
\hline Persimmon & 62 & 6 & 41 & 42 & $<0.0001$ & 37 \\
\hline Red Mulberry & 64 & 3 & 48 & 56 & $<0.0001$ & 41 \\
\hline Serviceberry & 76 & 46 & 26 & 14 & $<0.0001$ & 44 \\
\hline $\begin{array}{l}\text { Washington } \\
\text { Hawthorn }\end{array}$ & 41 & 30 & 70 & 98 & $<0.0001$ & 54 \\
\hline Wild Plum & 82 & 16 & 43 & 26 & $<0.0001$ & 44 \\
\hline TOTAL & 51 & 25 & 42 & 45 & & 40 \\
\hline
\end{tabular}

The Elk Run site showed the overall highest survival at 51\%, Fola and ICG were intermediate at 45 and 42\%, respectively, and the Hobet site had the lowest at 25\%. Species survival significantly ( $\mathrm{p}<0.0001)$ varied among sites for all species except black cherry and hazelnut. Both of these species had relatively good survival compared to other species across all sites. 
Aspect had a significant effect on survival ( $\mathrm{p}<0.0001)$. The west-facing blocks had an overall greater survival of $44 \%$ than the east-facing blocks of $36 \%$. The effect of aspect on the individual species level was analyzed (Figures 12A-C).

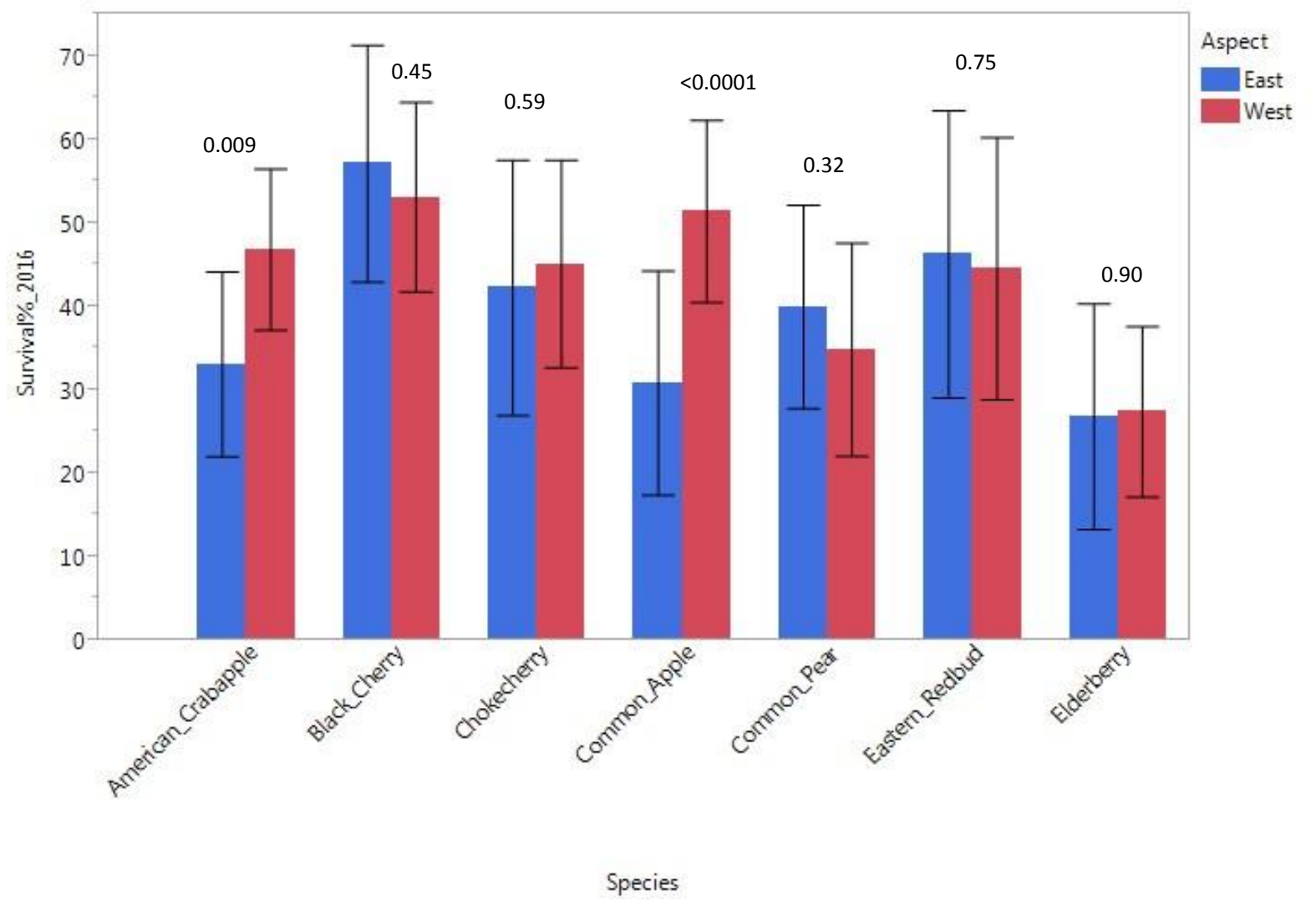

Figure 12A. Survival percentages in 2016 of seven tree species (A-E) by aspect with error bars and Chi-square p-values shown. 


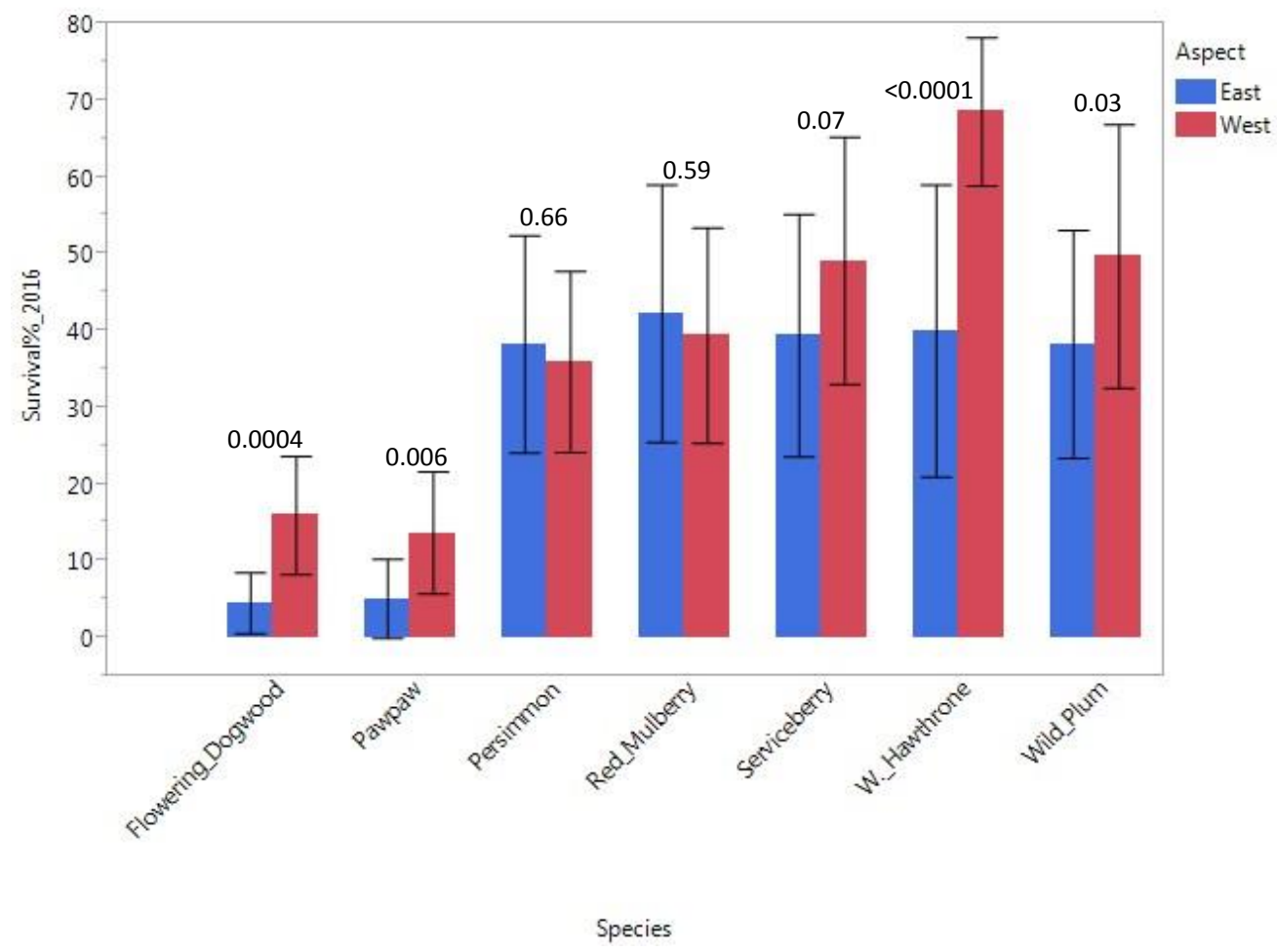

Figure 12B. Survival percentages in 2016 of seven tree species (F-W) by aspect with error bars $(\mathrm{p}<0.0001)$. 


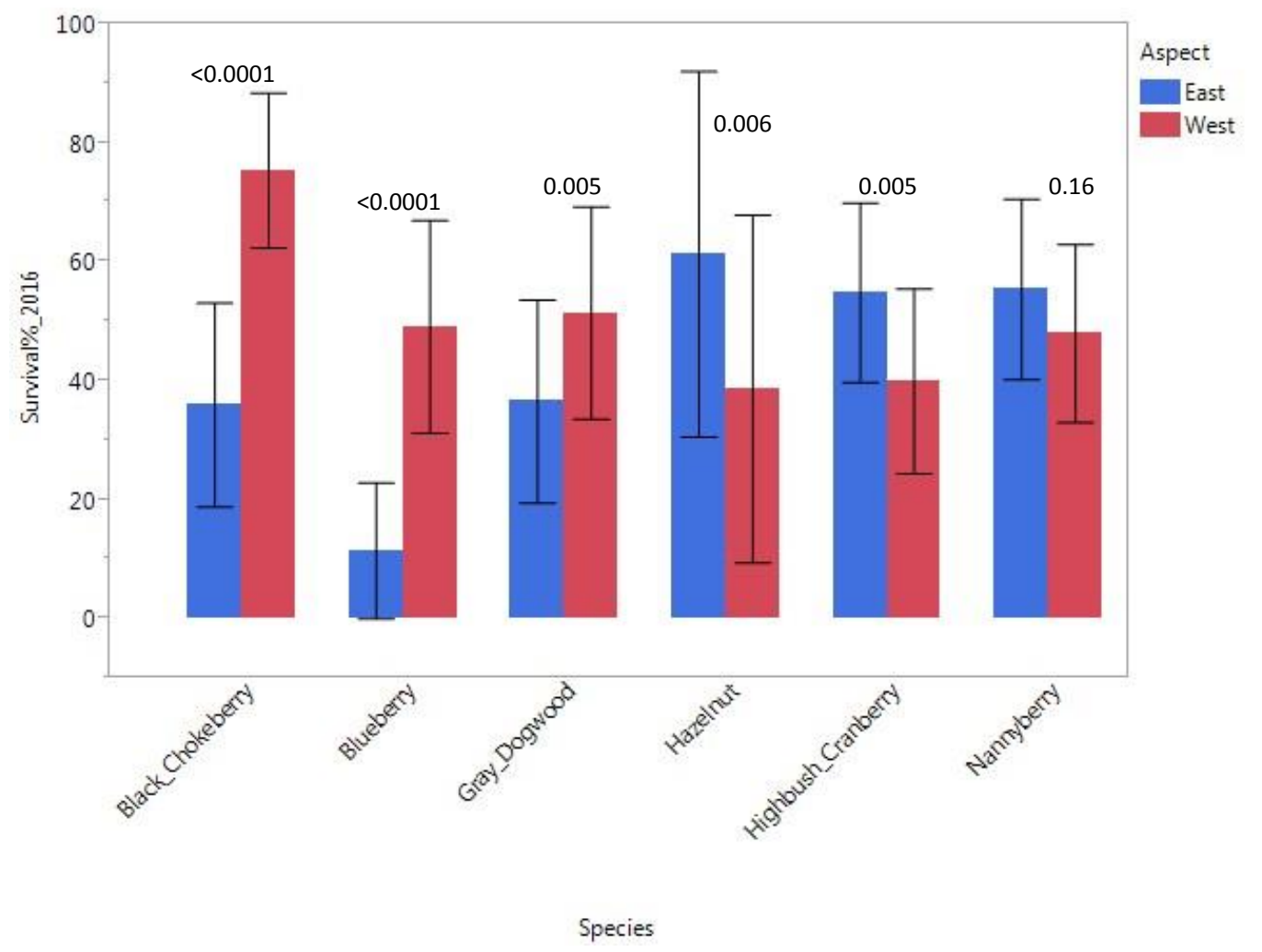

Figure 12C. Survival percentages in 2016 of shrub species by aspect with error bars $(\mathrm{p}<0.0001)$.

Black cherry and hazelnut were the only species that did not exhibit a significant difference in survival between the two aspects included in the study (Figures 12A-C). Many species exhibited the same trend as the trend observed in the study overall, with the west-facing blocks having better survival than the east-facing blocks. The exceptions to this included black cherry, common pear, eastern redbud, hazelnut, highbush cranberry, nannyberry, persimmon, and red mulberry which showed greater survival on east-facing blocks. Survival percentages for planted woody species were significantly different between the sites with Elk Run starting between 70-100\% and arriving at 50\% in 2016, while Hobet had only between 50-75\% survival the first year and 25-50\% survival in 2016.

Shrub survival after the first year was usually about 5 to $10 \%$ higher than tree survival after the first year (Table 6). For example, Elk Run had 87\% shrub survival and 76\% tree survival after the first year, which dropped to $60 \%$ for shrubs and $48 \%$ for trees after the $8^{\text {th }}$ year. Many species did not survive well after the first year, and survival continued to decline with time. Other species, like wild plum and persimmon, had good survival the first year and showed good survival after the initial transplanting shock period. 
Table 6. The nonzero correlation of age and survival of species on the older sites (Elk Run and Hobet) planted in 2008. Significance was determined by p-value <0.05. P-values derived from the repeated frequency analysis using the ridit scores of the Manel_Haenszel procedure. The nonzero correlation value was used because of the repeated measures.

\begin{tabular}{|c|c|c|c|c|}
\hline & \multicolumn{3}{|c|}{$\begin{array}{c}\text { Survival with respect to year } \\
\text { planted (years) }\end{array}$} & $\begin{array}{c}\text { Nonzero correlation; } \\
\text { QcsMH p-value }\end{array}$ \\
\hline Species & $\mathbf{1}$ & $\mathbf{7}$ & $\mathbf{8}$ & 0.56 \\
\hline American Crabapple & 56 & 55 & 52 & 0.38 \\
\hline Black Cherry & 67 & 51 & 56 & 0.02 \\
\hline Black Chokeberry & 84 & 43 & 43 & 0.15 \\
\hline Blueberry & 73 & 45 & 44 & 0.005 \\
\hline Chokecherry & 91 & 51 & 50 & 0.005 \\
\hline Common Apple & 81 & 30 & 30 & 0.15 \\
\hline Common Pear & 44 & 26 & 25 & 0.27 \\
\hline Eastern Redbud & 61 & 46 & 42 & 0.11 \\
\hline Elderberry & 48 & 18 & 18 & 0.15 \\
\hline Flowering Dogwood & 12 & 6 & 6 & 0.64 \\
\hline Gray Dogwood & 45 & 44 & 42 & 0.09 \\
\hline Highbush Cranberry & 75 & 49 & 49 & 0.02 \\
\hline Nannyberry & 86 & 55 & 53 & 0.0002 \\
\hline Pawpaw & 64 & 0 & 0 & 0.007 \\
\hline Persimmon & 80 & 35 & 34 & 0.23 \\
\hline Red Mulberry & 55 & 34 & 34 & 0.40 \\
\hline Serviceberry & 80 & 67 & 61 & 0.02 \\
\hline Washington Hawthorne & 71 & 40 & 36 & 0.05 \\
\hline Wild Plum & 84 & 51 & 49 & \\
\hline
\end{tabular}

Of the 19 species included in the study, eight of them showed a significant decline in survival between ages 1 and 8. Significance was determined by the QсsmH values found in the Cochran-Mantel-Haenszel test. If the probability was found to be $<0.05$ they were considered significant. The severity of the decrease in survival was specific with some species like Washington hawthorn having a severe decline in survival from 72 to $36 \%$, while others declined but not at such a precipitous rate. Pawpaw had the lowest survival percentage at age 1 and at age 8 , and most of the individuals of this species died. This was the most dramatic decline among all the species. Chokecherry had the highest average survival after the first year (92\%) and survived well to $50 \%$ after year 8 . Common apple, persimmon, and Washington hawthorn also experienced significant declines in survival after the first year. Species with survival percentages under $50 \%$ in 
the later years may indicate that they may not be species that operators should plant during reforestation projects. This large mortality in the year seedlings were planted is possible because either the planting stock was of poor quality, planting conditions and techniques were poor, or that the species were not suited or adapted to the conditions of the site.

Other species did not experience such an intense survival decline after planting and during the first growing season. These species may be better suited to the growing environment than those that had greater than $50 \%$ mortality in the first year. Serviceberry had the highest survival at $80 \%$ after the first year, and ended up having a high survival after 8 years of $61 \%$. Gray dogwood started out with $46 \%$ survival and ended with survival at $42 \%$, demonstrating that this species, once established, persisted on mine sites. Blueberry and highbush cranberry experienced dramatic mortality.

The same analysis was conducted for the younger sites (Fola and ICG) which were established in 2010. Again, the data were not normally distributed and exhibited a leftskewedness that could not be fixed by using transformations. As a result, frequency analysis was used in order to test the effect of time on survival on ICG and Fola.

Unlike the two older sites, Fola and ICG had similar survival percentages in year 1 between the two growth forms. At Fola at the end of year 1, the shrubs had $87 \%$ survival while trees had $76 \%$. By year 6 , the percent survival was reduced to $51 \%$ for shrubs and survival followed the same trend at Fola and ICG as shown at the other sites (Elk Run and Hobet) with survival diminishing with age. A few species experienced a die-out during 2010, the year of establishment, and they began with low survival percentages in year 1 and continued to decline with age. The majority of species did not have a dramatic die off during year 1, but instead experienced mortality after the first year and in between later sampling times. This was different from what was the most prevalent situation on the older sites, where the most severe mortality occurred during the first growing season. 
Table 7. The nonzero correlation of age and survival of species on the older sites (Elk Run and Hobet) planted in 2010. Significance was determined by p-value $<0.05$. P-values derived from the repeated frequency analysis using the ridit scores of the Manel_Haenszel procedure. The nonzero correlation value was used because of the repeated measures.

\begin{tabular}{|c|c|c|c|c|}
\hline & \multicolumn{3}{|c|}{$\begin{array}{c}\text { Survial with respect to year } \\
\text { planted (years) }\end{array}$} & $\begin{array}{c}\text { Nonzero correlation; } \\
\text { QcsMH p-value }\end{array}$ \\
\hline Species & $\mathbf{1}$ & $\mathbf{5}$ & $\mathbf{6}$ & \\
\hline American Crabapple & 35 & 22 & 25 & 0.46 \\
\hline Black Cherry & 91 & 54 & 54 & 0.05 \\
\hline Black Chokeberry & 100 & 73 & 73 & 0.01 \\
\hline Blueberry & 43 & 12 & 12 & 0.03 \\
\hline Chokecherry & 87 & 36 & 36 & 0.01 \\
\hline Common Apple & 97 & 56 & 56 & 0.009 \\
\hline Common Pear & 97 & 54 & 54 & 0.008 \\
\hline Eastern Redbud & 87 & 50 & 50 & 0.28 \\
\hline Elderberry & 48 & 39 & 40 & 0.96 \\
\hline Flowering Dogwood & 71 & 17 & 17 & 0.008 \\
\hline Gray Dogwood & 89 & 47 & 47 & 0.31 \\
\hline Hazelnut & 93 & 51 & 50 & 0.06 \\
\hline Highbush Cranberry & 83 & 46 & 46 & 0.10 \\
\hline Nannyberry & 73 & 50 & 50 & 0.29 \\
\hline Pawpaw & 73 & 22 & 22 & 0.005 \\
\hline Persimmon & 94 & 41 & 41 & 0.005 \\
\hline Red Mulberry & 95 & 51 & 51 & 0.06 \\
\hline Serviceberry & 65 & 22 & 22 & 0.03 \\
\hline Washington Hawthorne & 99 & 79 & 79 & 0.12 \\
\hline Wild Plum & 95 & 37 & 37 & 0.03 \\
\hline
\end{tabular}

Of the 20 species planted at Fola and ICG, the survival of 10 species significantly changed over time. Survival leveled off as time progressed, showing the number of surviving plants persisted with time. Black chokeberry began with the highest survival percentage at year 1 at $100 \%$, and this species had the highest overall shrub survival percentage after year 6 with $73 \%$. Blueberry started out with the lowest survival at $43 \%$ and finished with the lowest survival percentage of $12 \%$. The survival percentage achieved by each species heavily depended on the survival success in the year of establishment.

Comparing these species and survival averages to those found to be significant on the older sites, time was significant to more species' survival on the younger sites than the older sites. It is clear that the younger sites had higher survival percentages after year 1, with many above $90 \%$. 
Blueberry, chokecherry, flowering dogwood, persimmon, serviceberry, and wild plum all fell below 50\% survival after year 6 . American crabapple and elderberry had less than $50 \%$ surviving after the first year. Nannyberry had better survival without a severe drop in survival in year 1 with $73 \%$ surviving, but survival at the end of year 6 was reduced to $50 \%$. Washington hawthorn showed the best overall survival, starting with the highest (100\%) alive after year 1 and finishing with around $80 \%$ in year 6 . For some of the species, a significant pvalue was not found. These species, including hazelnut and red mulberry, had low mortality rates after year 1 and remained above $80 \%$ survival. The average survival in years 5 and 6 was similar for all species in this group, around $50 \%$.

\section{Height}

The average height of all shrubs was $1.26 \mathrm{~m}$, while trees averaged $1.40 \mathrm{~m}$. As expected, the trees tended to grow straight upward with a dominant meristem, rather than shrubs which tended to spread and not have a dominant main stem. However, the height differences were not significantly different between the two growth forms in 2016 more than 6 or 8 years after establishment.

Two of the four sites, Elk Run and Hobet, were planted in 2008 while the other sites in the study, Fola and ICG, were not planted until 2010. Due to the two-year difference in growth times, the four sites were separated into two age groups for analysis based on the year they were planted. The height of the older plants of the same species were expected to be taller than those of the younger species so the comparison across sites would not be appropriate.

When comparing the height differences between the shrubs and trees at the sites planted in 2008, Elk Run and Hobet, no significant difference was found between the two (Figure 13). The tree group was slightly taller than the shrub group on average, but the difference was not significant. Trees were again greater in height numerically than shrubs at the sites planted in 2010, however the difference was not great enough to be considered significant. Hobet had the lowest average heights for both trees and shrubs and Elk Run and Fola trees were taller than Hobet and ICG trees. Elk Run was found to have the tallest shrubs, and Fola was found to host the tallest trees. At ICG, the average shrub and tree heights were very similar. 


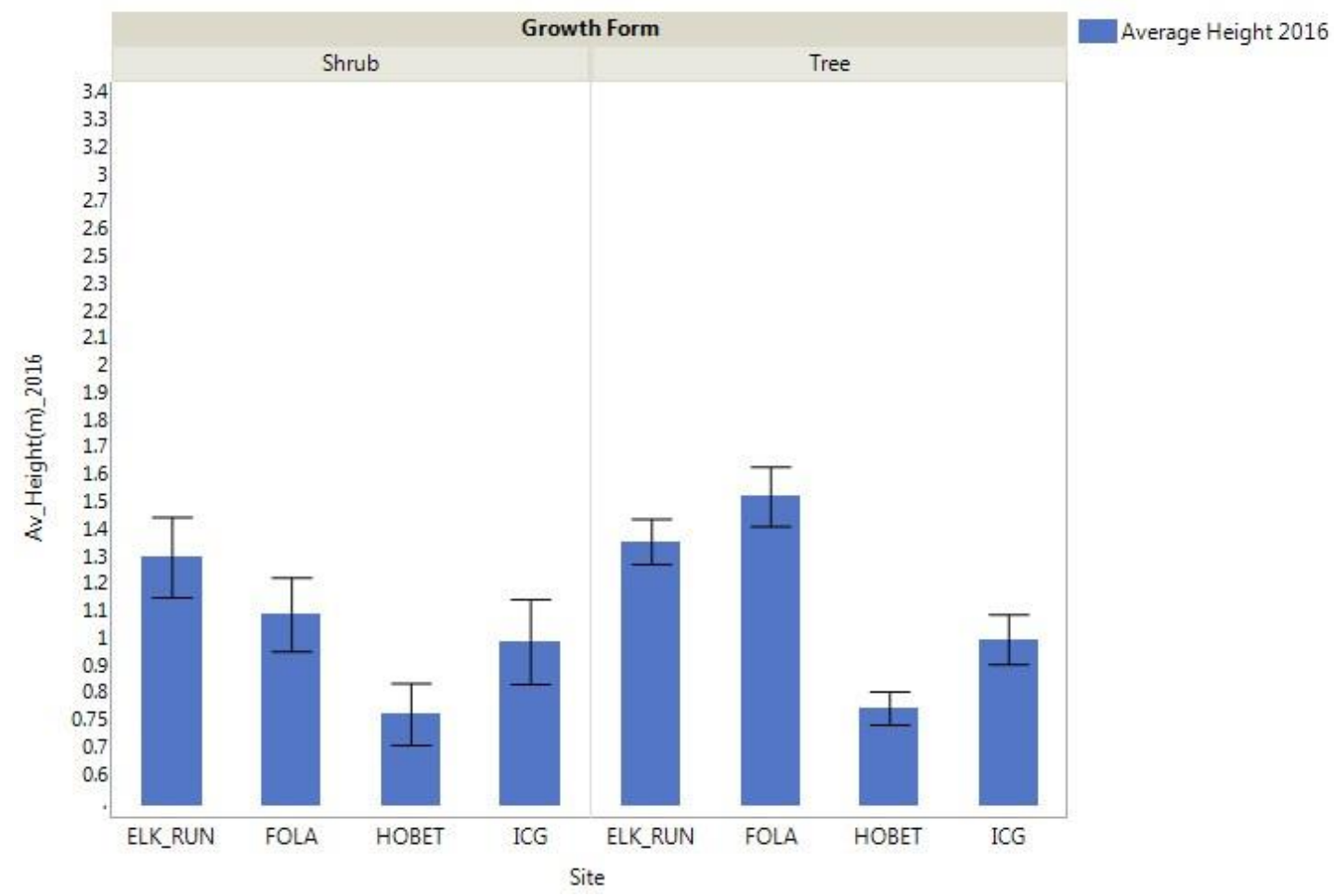

Figure 13. Average height of shrubs and trees on each site in 2016.

To further explore the effect of site on height, each species was analyzed separately so that the differences in average height in 2016 were compared within species across sites. Height differences across species were not analyzed because of inherent differences in growth rates and general height conditions among the species even within growth forms. There were significant differences in average heights within a species across sites. In order to make comparisons, the 20 species were separated as detailed above: 2 figures for the two groups of trees ordered alphabetically, and one figure for the six shrubs.

As mentioned, Fola generally had the tallest plants, while Hobet consistently had the smallest plants of any site (Figure 13). This result was surprising considering that the plants at Hobet were 2 years older than those at Fola, but the low survival percentages at Hobet were reflected in the poor growth conditions. This similarity in heights was found for all species in Figure 14A at Elk Run and Fola except for common apple, where Fola apple trees were found to be significantly taller. The seven trees at ICG and Hobet were not significantly different from each other within species and were generally shorter than those at Elk Run and Fola. 


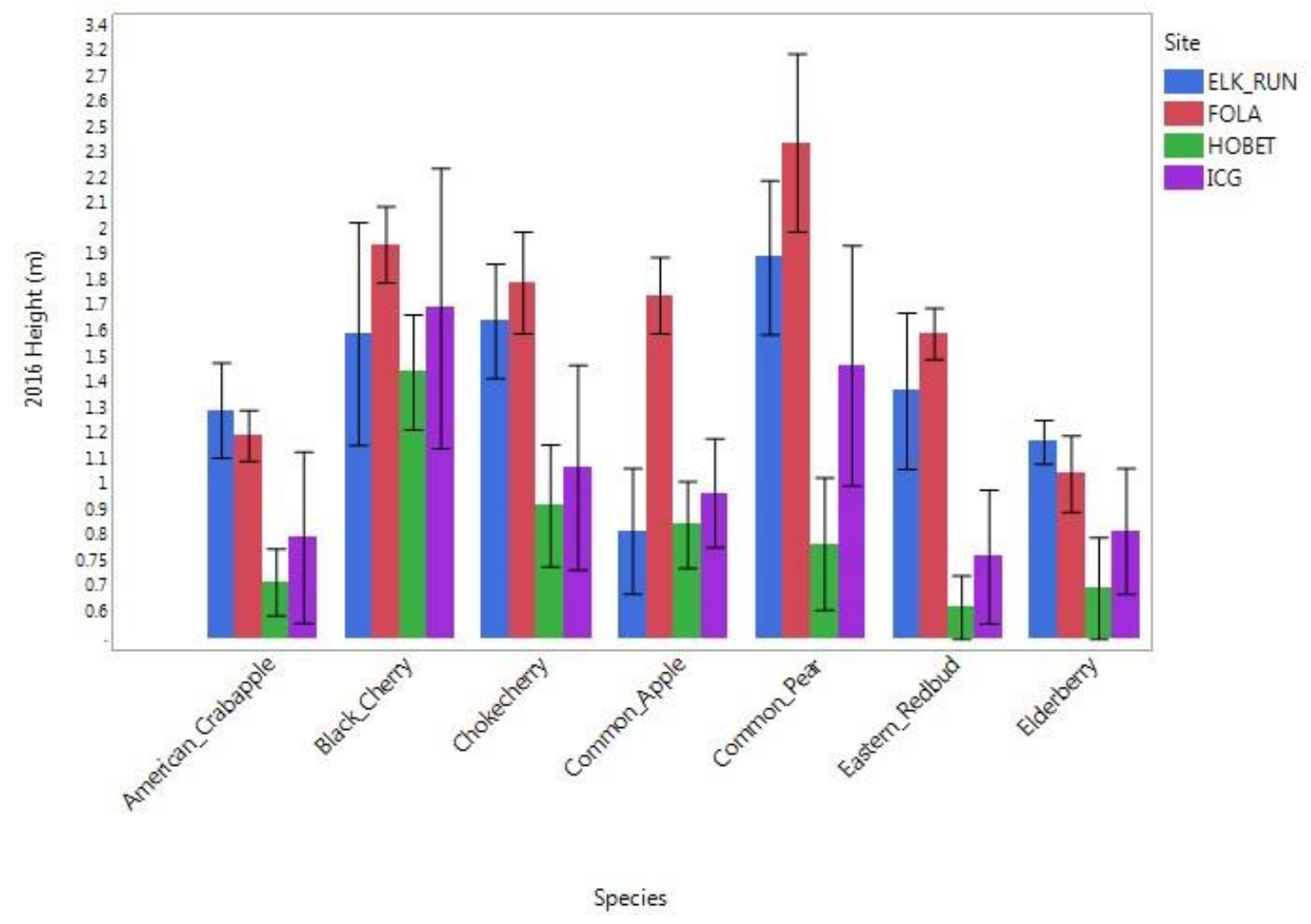

Figure 14A. Average height of seven trees (A-E) on all four sites in 2016.

The second group of trees (Figure 14B) followed the same overall trend that was displayed in Figure 14A, with the Fola site having the tallest plants for most species. However, even though Fola had the tallest plants, the average heights for trees at Elk Run and Fola were not significantly different in most cases. Persimmon and Washington hawthorn were found to be the exceptions, with significant differences between heights at Elk Run and Fola. Serviceberry achieved the greatest height on average of any species on this figure, and pawpaw was found to be the shortest. The average height of pawpaw was a reflection of the poor survival and overall poor growth of this species. 


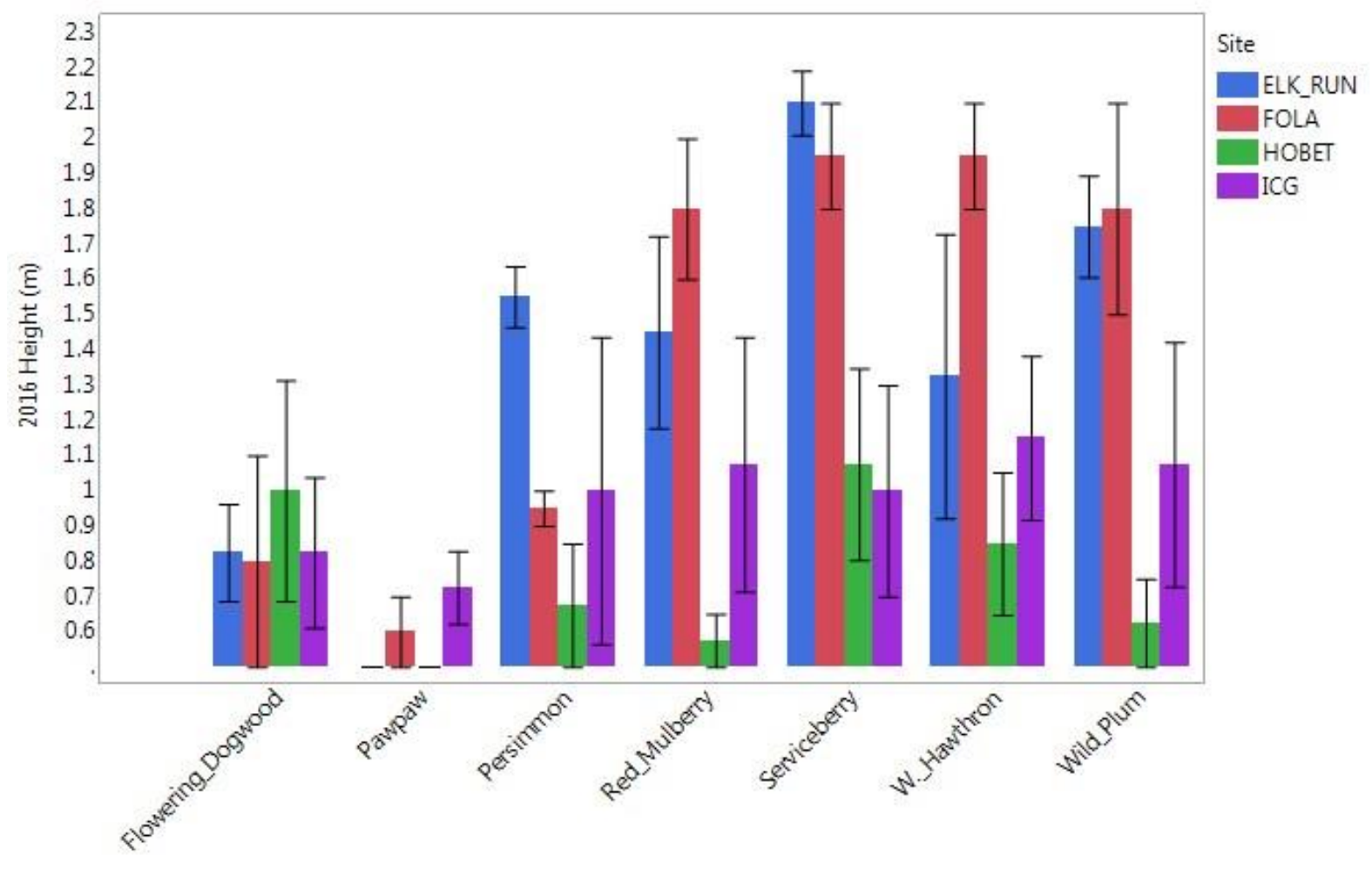

Species

Figure 14B. Average height of seven trees (F-W) on four sites in 2016.

Average height of the shrub species across sites are shown in Figure 14C. The growth of black chokeberry and hazelnut were significantly higher at Fola when compared to other sites (Figure 14C). Gray dogwood grew well at Elk Run, as did highbush cranberry and nannyberry.

Hobet was the site of worst performance for many of the species except for blueberry, where Hobet showed the best growth. Hazelnut was not planted at Elk Run and Hobet. 


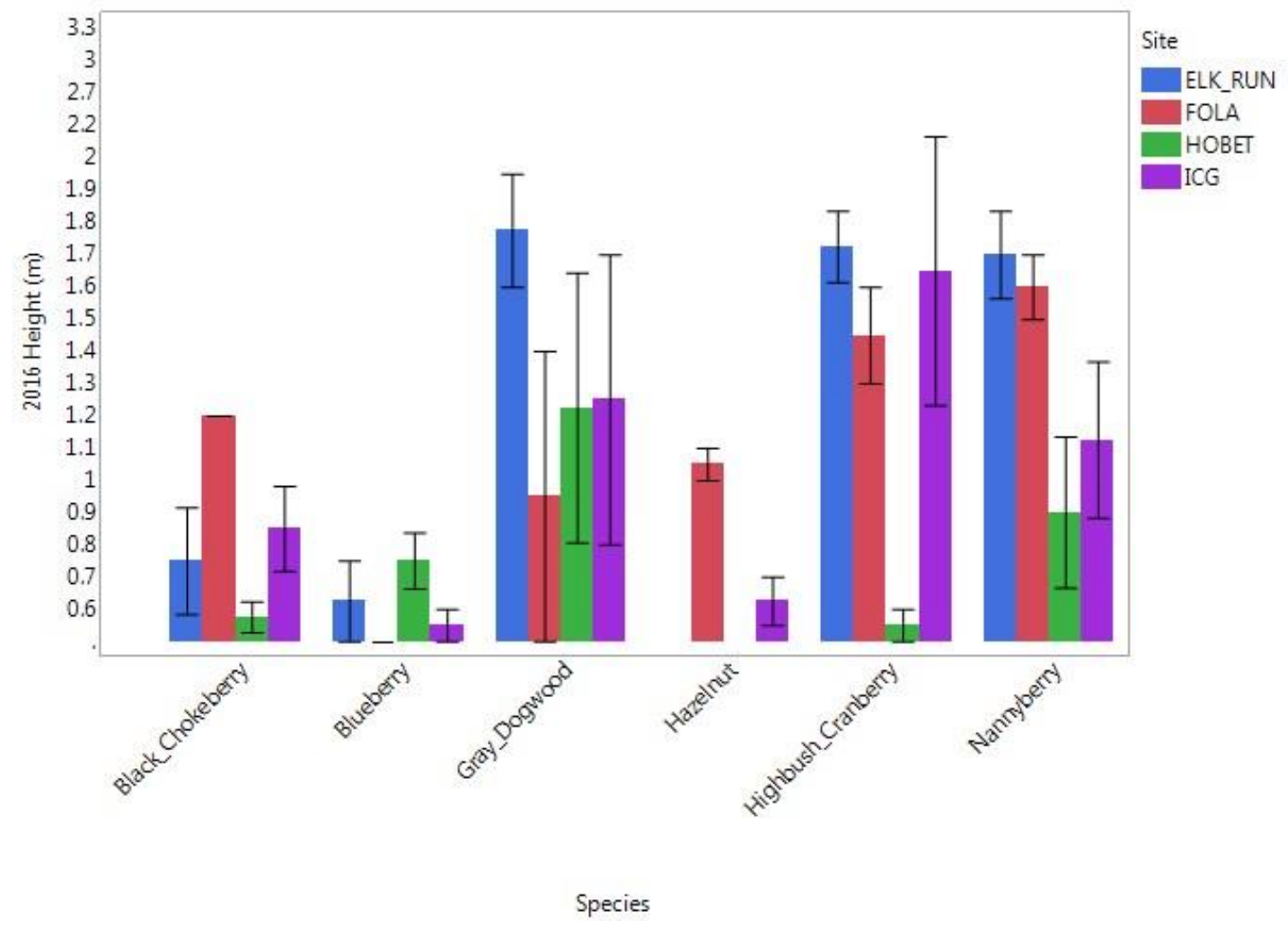

Figure 14C. Average height of six shrubs on all four sites in 2016.

The effect of aspect on height for shrubs and trees were tested against average height of each growth form and were not shown to be significantly different between aspects (data not shown). More clear height differences were observed when the average heights were separated by site and aspect (Figure 16). For both growth forms, Hobet had the shortest plants. The shrubs exhibited no significant difference between aspects on any site. Significant differences were found for tree height between Hobet and the two sites, Fola and Elk Run, on the west-facing aspects. For the trees species in this study, signficant differences were found between the eastand west-facing aspects at Hobet and ICG. ICG and Hobet were more similar in average tree heights compared to the other sites, but the trend observed between the two sites was different. At Hobet, the west-facing blocks had significantly taller trees, and at ICG the east-facing blocks had significantly taller trees. Fola and Elk Run showed no height differences between aspects. 


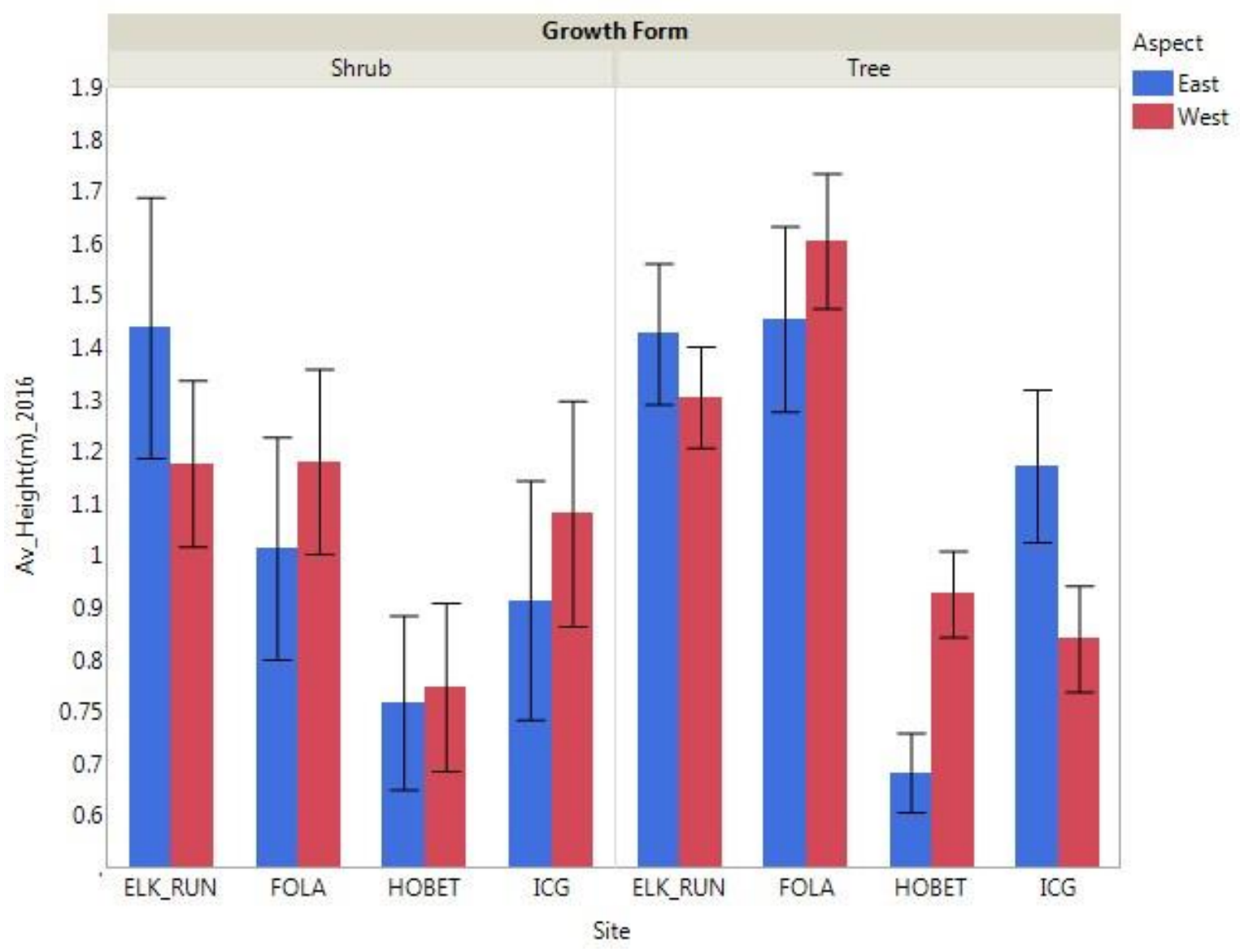

Figure 15. Average height in 2016 for shrubs and trees between the east- and west-facing aspects by site.

The effect of aspect on the average height of each species is shown in Figures 23A-C. Again, due to the quantity of species included in this study they were separated into three groups, two tree groups (alphabetically ordered A-E and F-W) and the shrubs. It was hypothesized that trees growing on east-facing aspects would have greater heights since these aspects normally result in cooler and wetter soil conditions than west-facing aspects. For some species, tree and shrub heights tended to be greater on the west-facing aspect than the east-facing aspect. The exceptions were black cherry, chokecherry, and common pear (Figures 16A and 16B). But the differences in average height between the two aspects was found to be mostly insignificant. The exceptions were common apple, flowering dogwood, and Washington hawthorn where the westfacing blocks had taller trees than the east-facing ones. 


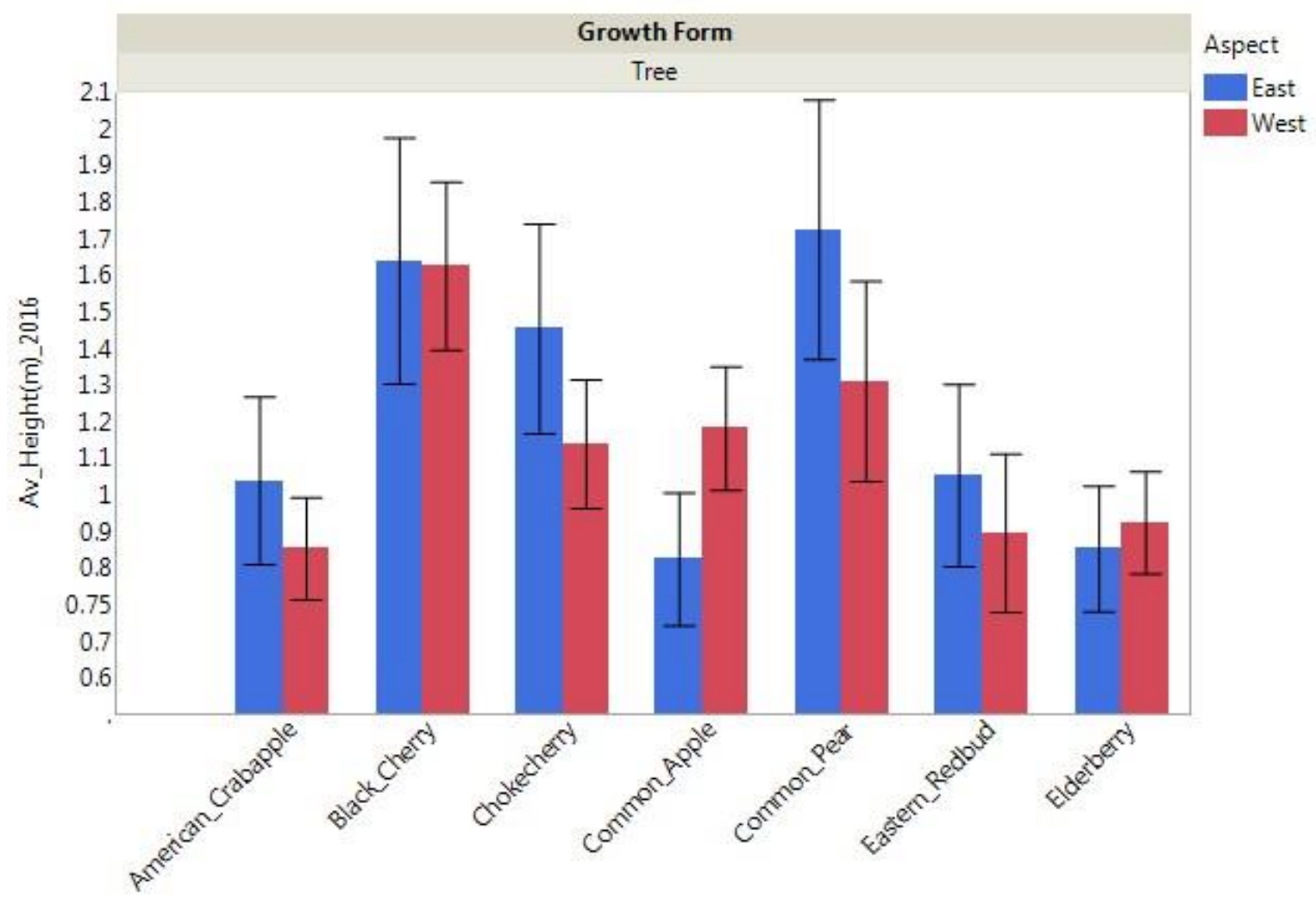

Species

Figure 16A. Average height of selected tree species (A-E) in 2016 at all sites between the eastand west- facing aspects. 


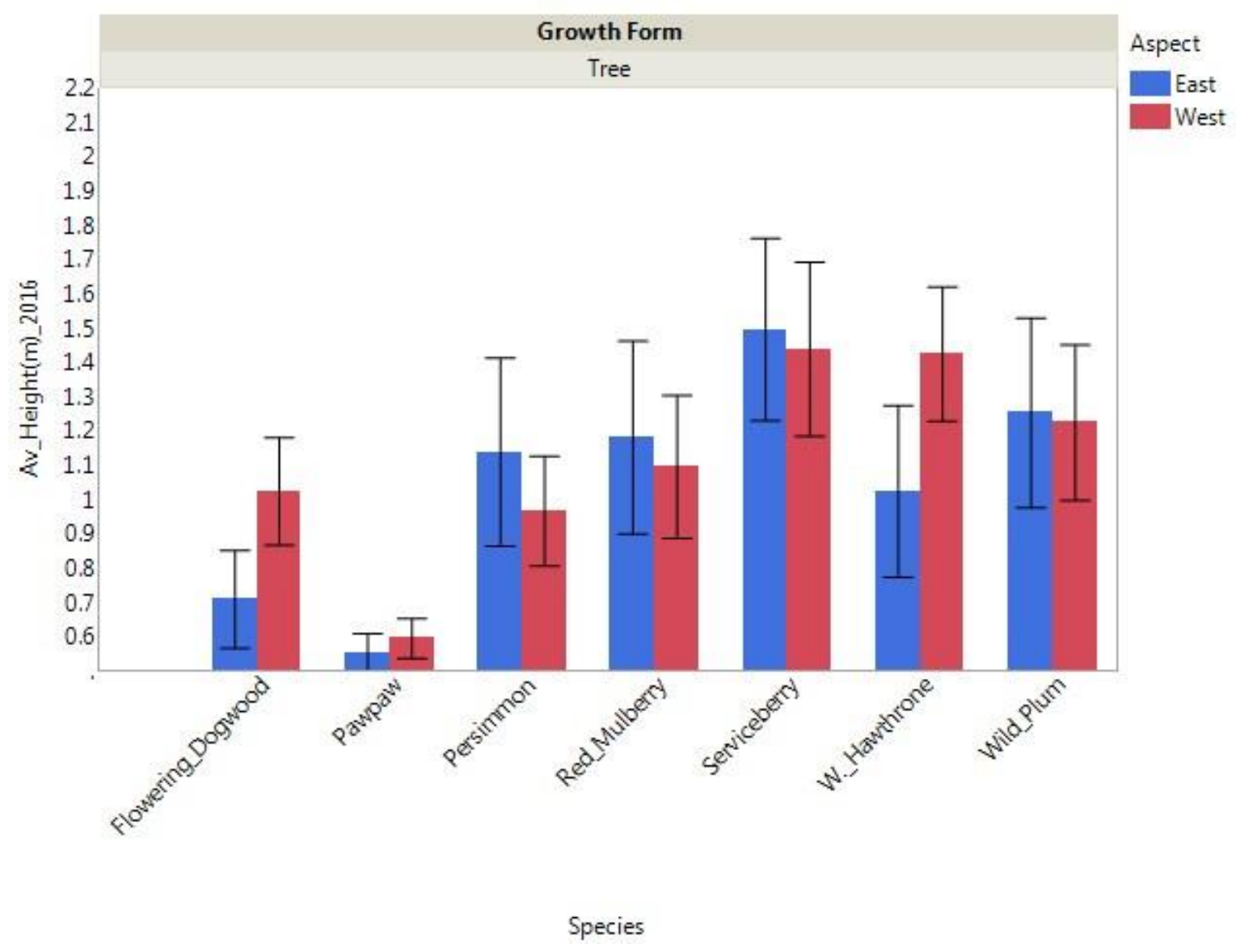

Figure 16B. Average height of selected tree species (F-W) in 2016 at all sites between the eastand west-facing aspects.

The shrub species showed similar results to the tree species with aspect. The shrubs on west-facing aspects had higher average height values than the east-facing aspects, but significant differences between aspects within the same species were not found. 


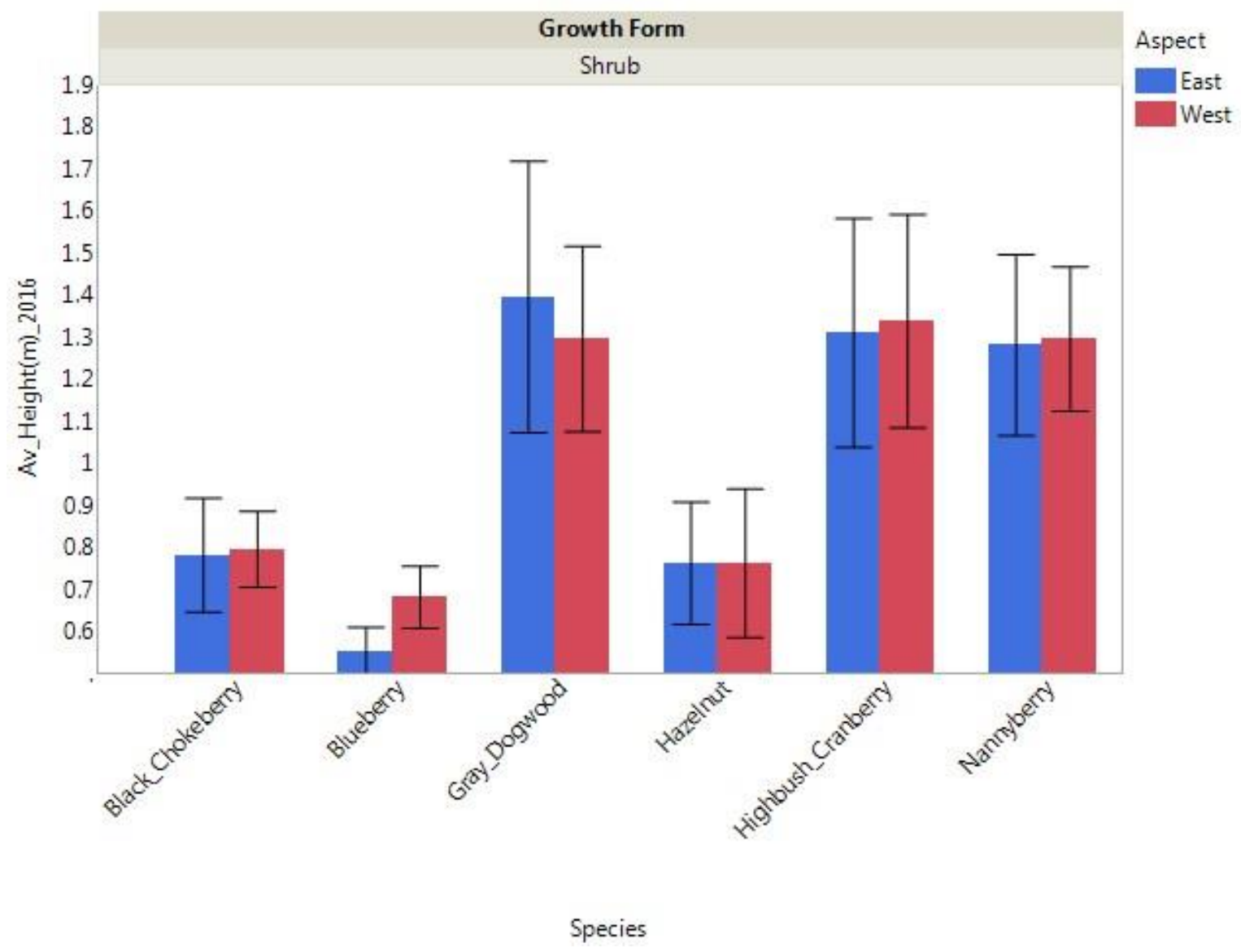

Figure 16C. Average height of shrubs in 2016 at all sites between the east- and west-facing aspects.

The interaction of aspect and site was also analyzed for the average heights of each individual tree species (graphs not shown). At Elk Run, the trees on east-facing blocks were generally taller than those on west-facing blocks. Common apple was the only species where the trees on westfacing aspects grew better than the east-facing aspects. At Fola, the trees on westfacing aspects overall had taller plants than east-facing aspects, with exceptions being black cherry, chokeberry, and common pear. Hobet showed the most dramatic difference in average heights between aspects. This is due to the partial demolition of the east-facing blocks at Hobet in the year of establishment, 2008. At ICG, most trees grew taller on east-facing aspects, but even though numerically higher, the differences weren't significant. 
The shrub species showed similar results to the tree species when testing the interaction of aspect by site for each species (graphs not shown). Elk Run showed the east-facing blocks having greater average height than the west-facing blocks with the exception of blueberry. No significant differences were observed between aspects within species at Elk Run. Shrubs at Fola did not show a strong trend for either aspect. Within species at Fola, the only significant difference in height between aspects was found for gray dogwood, where the west-facing block had significantly taller trees. Hobet showed a less dramatic difference between aspects compared to the tree species. No significant differences between aspects were found within species at Hobet. Average heights for individual species were not significantly different between aspects at ICG.

As expected, trees and shrubs on these sites showed significant growth during the time between the first year after planting and either 6 or 8 years later (Tables 8 and 9). The height data were more normally distributed than the survival data, and as a result an ANOVA was run to test the effect of age, site, aspect, and their interactions using age as a repeated measure. 
Table 8. Average height of each species after one growing season and after 8 growing seasons on the sites planted in 2008, Elk Run and Hobet, using age as a repeated measure. The TukeyKramer adjustment was made to the calculated p-values in order to make the test more conservative and control type I errors from occurring.

\begin{tabular}{|l|c|c|c|}
\hline & \multicolumn{2}{|c|}{ Height (m) } & P-value \\
\hline \multicolumn{1}{|c|}{ Species } & Year 1 & Year 8 & \\
\hline American Crabapple & 0.20 & 1.07 & $<0.0001$ \\
\hline Black Cherry & 0.76 & 1.70 & 0.0003 \\
\hline Black Chokeberry & 0.36 & 0.83 & 0.007 \\
\hline Blueberry & 0.19 & 0.87 & $<0.0001$ \\
\hline Chokecherry & 0.39 & 1.42 & $<0.0001$ \\
\hline Common Apple & 0.31 & 1.10 & $<0.0001$ \\
\hline Common Pear & 0.22 & 1.65 & 0.0001 \\
\hline Eastern Redbud & 0.44 & 1.29 & 0.004 \\
\hline Elderberry & 0.23 & 1.12 & $<0.0001$ \\
\hline Flowering Dogwood & 0.47 & 1.16 & 0.01 \\
\hline Gray Dogwood & 0.41 & 1.91 & $<0.0001$ \\
\hline Highbush Cranberry & 0.37 & 1.53 & 0.0002 \\
\hline Nannyberry & 0.39 & 1.57 & $<0.0001$ \\
\hline Pawpaw & 0.36 & - & - \\
\hline Persimmon & 0.37 & 1.48 & $<0.0001$ \\
\hline Red Mulberry & 0.50 & 1.30 & 0.005 \\
\hline Serviceberry & 0.38 & 1.74 & $<0.0001$ \\
\hline Washington Hawthorn & 0.39 & 1.47 & 0.0004 \\
\hline Wild Plum & 0.71 & 1.59 & 0.0005 \\
\hline
\end{tabular}


Table 9. Average height of each species after the first growing season and after 6 growing seasons on sites planted in 2010, Fola and ICG, using age as a repeated measure. The Tukey-Kramer adjustment was made to the calculated p-values in order to make the test more conservative and control type I errors from occurring.

\begin{tabular}{|l|c|c|c|}
\hline & \multicolumn{2}{|c|}{ Height $(\mathbf{m})$} & p-value \\
\hline \multicolumn{1}{|c|}{ Species } & Year 1 & Year 6 & \\
\hline American Crabapple & 0.18 & 1.22 & 0.01 \\
\hline Black Cherry & 0.38 & 2.20 & 0.0005 \\
\hline Black Chokeberry & 0.43 & 1.05 & $<.0001$ \\
\hline Blueberry & 0.12 & 0.65 & 0.003 \\
\hline Chokecherry & 0.28 & 1.78 & $<.0001$ \\
\hline Common Apple & 0.58 & 1.42 & 0.002 \\
\hline Common Pear & 0.42 & 2.16 & 0.0003 \\
\hline Eastern Redbud & 0.30 & 1.34 & 0.0005 \\
\hline Elderberry & 0.04 & 1.15 & $<.0001$ \\
\hline Flowering Dogwood & 0.15 & 1.14 & 0.0002 \\
\hline Gray Dogwood & 0.38 & 2.04 & 0.006 \\
\hline Hazelnut & 0.35 & 0.90 & 0.0003 \\
\hline Highbush Cranberry & 0.23 & 2.00 & 0.0004 \\
\hline Nannyberry & 0.30 & 1.43 & $<.0001$ \\
\hline Pawpaw & 0.13 & 0.78 & $<.0001$ \\
\hline Persimmon & 0.25 & 1.23 & 0.02 \\
\hline Red Mulberry & 0.32 & 1.73 & 0.003 \\
\hline Serviceberry & 0.20 & 1.74 & $<.0001$ \\
\hline Washington Hawthorn & 0.63 & 1.60 & 0.0003 \\
\hline Wild Plum & 0.37 & 1.72 & $<.0001$ \\
\hline
\end{tabular}

The age shown is the time at which tree height was sampled. Age 1 represents tree height after one growing season after transplanting in 2008. Age 7 represents the height measured 7 years later, in the summer of 2015 at Elk Run and Hobet. Age 8 represents height measurements collected in the summer of 20168 years after establishment. The ANOVA was adjusted to account for the irregular spacing of the sampling ages for analysis.

The plants at Elk Run were taller on average in years 7 and 8 than those at Hobet in the same years of growth, regardless of growth form (Figure 17). At age 1, the plants did not significantly differ in height between sites. A significant difference was found in average height between ages 1 and 7 and ages 1 and 8. However, no significant difference in growth was found between ages 7 and 8 for either growth form. 


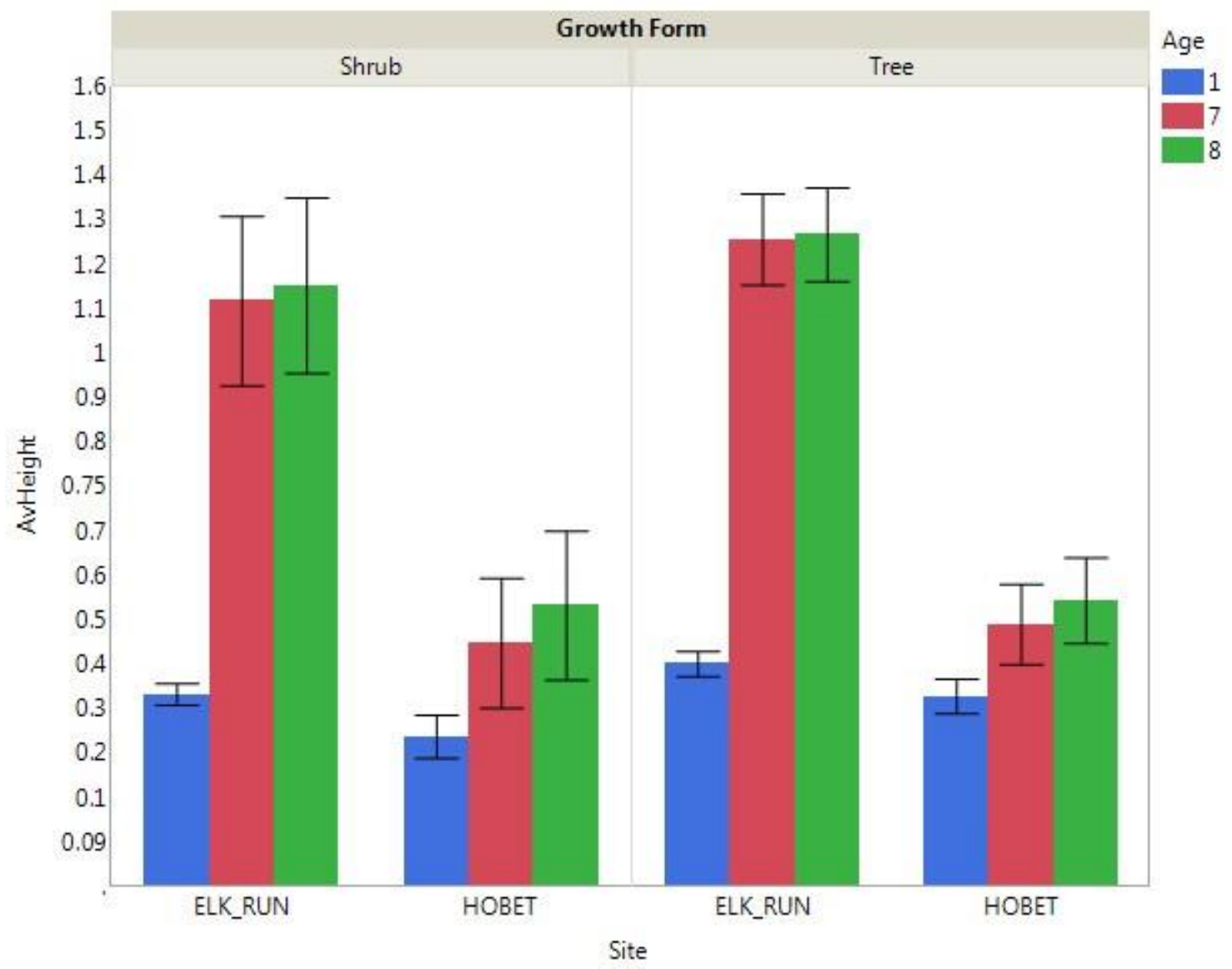

Figure 17. Average height of different growth forms separated by site (Elk Run and Hobet) after 8 years of growth.

When looking at individual species, all were found to be growing over time except for pawpaw, which experienced complete mortality on these two sites. Most species showed a significant difference in growth between age 1 and ages 7 and 8, excluding black chokeberry, blueberry, flowering dogwood, and wild plum (Table 10). These species still showed growth but it was slow and not significantly different from the original height, which was mostly due to poor survival of those species.

To further explore the effect of time on performance in the study, the two growth forms were separated by site so that site performance can be more closely examined and explained. 
Table 10. ANOVA results testing the effect of site on species height and the effect of the site*age interaction on the sites planted in 2008, Elk Run and Hobet, using age as a repeated measure. The Tukey-Kramer adjustment was made to the calculated p-values in order to make the test more conservative and control type I errors from occurring.

\begin{tabular}{|c|c|c|c|c|c|c|c|c|c|c|c|c|c|}
\hline \multirow{3}{*}{ Species } & \multirow[t]{3}{*}{ Prob F } & \multicolumn{2}{|c|}{ Means by site } & \multirow[t]{3}{*}{ p-value } & \multicolumn{6}{|c|}{ Prob F showing the effect of SITE * AGE } & \multicolumn{3}{|c|}{ p-value } \\
\hline & & \multirow{2}{*}{$\begin{array}{l}\text { Elk } \\
\text { Run }\end{array}$} & \multirow{2}{*}{ Hobet } & & \multicolumn{3}{|c|}{ Elk Run } & \multicolumn{3}{|c|}{ Hobet } & \multicolumn{3}{|c|}{ Elk Run and Hobet } \\
\hline & & & & & $\mathbf{1}$ & 7 & 8 & 1 & 7 & 8 & $\mathbf{1}$ & 7 & 8 \\
\hline $\begin{array}{l}\text { American } \\
\text { Crabapple }\end{array}$ & 0.04 & 0.94 & 0.53 & 0.03 & 0.08 & $<.0001$ & $<.0001$ & 0.24 & 0.0009 & 0.0003 & 0.9992 & 0.04 & 0.09 \\
\hline Black Cherry & 0.07 & 1.60 & 1.26 & 0.07 & 0.0004 & $<.0001$ & $<.0001$ & 0.0002 & $<.0001$ & $<.0001$ & 0.9990 & 0.32 & 0.20 \\
\hline $\begin{array}{l}\text { Black } \\
\text { Chokeberry }\end{array}$ & 0.02 & 0.80 & 0.51 & 0.02 & 0.0005 & $<.0001$ & $<.0001$ & 0.002 & 0.0004 & 0.0001 & 0.9972 & 0.11 & 0.23 \\
\hline Blueberry & 0.004 & 0.73 & 0.58 & 0.004 & $<.0001$ & $<.0001$ & $<.0001$ & $<.0001$ & $<.0001$ & $<.0001$ & 0.95 & 0.01 & $\begin{array}{c}0.098 \\
6\end{array}$ \\
\hline Chokecherry & 0.08 & 1.21 & 0.86 & 0.08 & 0.02 & $<.0001$ & $<.0001$ & 0.02 & $<.0001$ & $<.0001$ & 1.00 & 0.21 & 0.21 \\
\hline $\begin{array}{l}\text { Common } \\
\text { Apple }\end{array}$ & 0.010 & 0.95 & 0.70 & 0.010 & $<.0001$ & $<.0001$ & $<.0001$ & 0.0006 & $<.0001$ & $<.0001$ & 0.91 & 0.03 & 0.23 \\
\hline Common Pear & 0.17 & 1.33 & 0.83 & 0.17 & 0.36 & $<.0001$ & $<.0001$ & 0.41 & 0.008 & 0.006 & 1.00 & 0.33 & 0.36 \\
\hline $\begin{array}{l}\text { Eastern } \\
\text { Redbud }\end{array}$ & 0.20 & 1.08 & 0.66 & 0.20 & 0.04 & $<.0001$ & $<.0001$ & 0.07 & 0.10 & 0.04 & 1.00 & 0.52 & 0.79 \\
\hline Elderberry & 0.62 & 0.77 & 0.83 & 0.62 & 0.06 & $<.0001$ & $<.0001$ & 0.03 & $<.0001$ & $<.0001$ & 0.9962 & $\begin{array}{c}0.988 \\
6\end{array}$ & 1.00 \\
\hline $\begin{array}{l}\text { Flowering } \\
\text { Dogwood }\end{array}$ & 0.07 & 0.74 & 1.1 & 0.07 & 0.003 & 0.0002 & $<.0001$ & 0.005 & 0.002 & $<.0001$ & 0.9850 & 0.55 & 0.25 \\
\hline $\begin{array}{l}\text { Gray } \\
\text { Dogwood }\end{array}$ & 0.71 & 1.40 & 1.31 & 0.71 & 0.04 & $<.0001$ & $<.0001$ & 0.13 & 0.0001 & $<.0001$ & 1.00 & 0.92 & 1.00 \\
\hline $\begin{array}{l}\text { Highbush } \\
\text { Cranberry }\end{array}$ & 0.0004 & 1.23 & 0.61 & 0.0004 & 0.0007 & $<.0001$ & $<.0001$ & 0.0003 & 0.0005 & 0.0005 & 0.88 & 0.004 & 0.002 \\
\hline Nannyberry & 0.03 & 1.23 & 0.98 & 0.03 & 0.0005 & $<.0001$ & $<.0001$ & 0.0003 & $<.0001$ & $<.0001$ & 0.99 & 0.16 & 0.12 \\
\hline Pawpaw & 0.05 & 0.33 & 0.40 & 0.05 & $<.0001$ & - & - & $<.0001$ & - & - & 0.01 & - & - \\
\hline Persimmon & 0.02 & 1.16 & 0.86 & 0.02 & 0.001 & $<.0001$ & $<.0001$ & 0.003 & $<.0001$ & $<.0001$ & 1.00 & 0.01 & 0.24 \\
\hline Red Mulberry & 0.13 & 1.14 & 0.59 & 0.13 & 0.02 & 0.0003 & 0.0002 & 0.17 & 0.10 & 0.07 & 0.99 & 0.43 & 0.54 \\
\hline Serviceberry & 0.01 & 1.49 & 0.96 & 0.01 & 0.02 & $<.0001$ & $<.0001$ & 0.03 & $<.0001$ & $<.0001$ & 1.00 & 0.02 & 0.01 \\
\hline $\begin{array}{l}\text { Washington } \\
\text { Hawthorn }\end{array}$ & 0.26 & 1.18 & 0.89 & 0.26 & 0.08 & $<.0001$ & $<.0001$ & 0.06 & 0.002 & 0.0007 & 0.99 & 0.49 & 0.76 \\
\hline Wild Plum & 0.004 & 1.4 & 0.81 & 0.004 & $<.0001$ & $<.0001$ & $<.0001$ & $<.0001$ & 0.002 & 0.0004 & 0.99 & 0.02 & 0.06 \\
\hline
\end{tabular}

When comparing the two sites established in 2008, a clear difference in average height was shown (Table 10). Hobet had a much lower average height and fewer significant differences were observed between ages 1 and ages 7 and 8 . There are also some species at Hobet including eastern redbud, flowering dogwood, pawpaw, and wild plum that had a higher average height at age 1 than at age 7 . This is due to the change in survival percentage that occurred between ages 1 and 7. Elk Run showed only one species that had a higher average height at age 1 than at later ages, and that was pawpaw. Like Hobet, the reason was mortality.

The shrub species showed similar results to the tree species when comparing average height over time (Table 10). The average heights achieved by three of the shrubs were much greater at Elk Run than they were at Hobet. Gray dogwood, highbush cranberry, and nannyberry all 
showed a significant increase in height between age 1 and ages 7 and 8. Blueberry and black chokeberry still showed signs of growth, but at a much slower rate probably due to a large mortality of those species at Elk Run. Hobet showed a significant height difference between age 1 and ages 7 and 8 for only one species, gray dogwood. Blueberry, black chokeberry, and nannyberry all displayed signs of slow growth. Highbush cranberry survival was very low at Hobet, and as a result the average height was highest at age 1 and decreased over time.

The same ANOVA models were run for the effects of age and site at the younger sites (Fola and ICG) for the two growth forms and individual species. The two different growth forms showed a more significant effect on the sites planted in 2010, particularly at Fola (Figure 18). At Fola, a significant difference was found between the growth forms at ages 5 and 6 . This relationship was not mirrored at ICG, where the difference in average height between growth forms was not significant. Plants growing at ICG did not grow as well over the same time period as those at Fola. Different survival rates between the sites may have influenced the average height numbers.

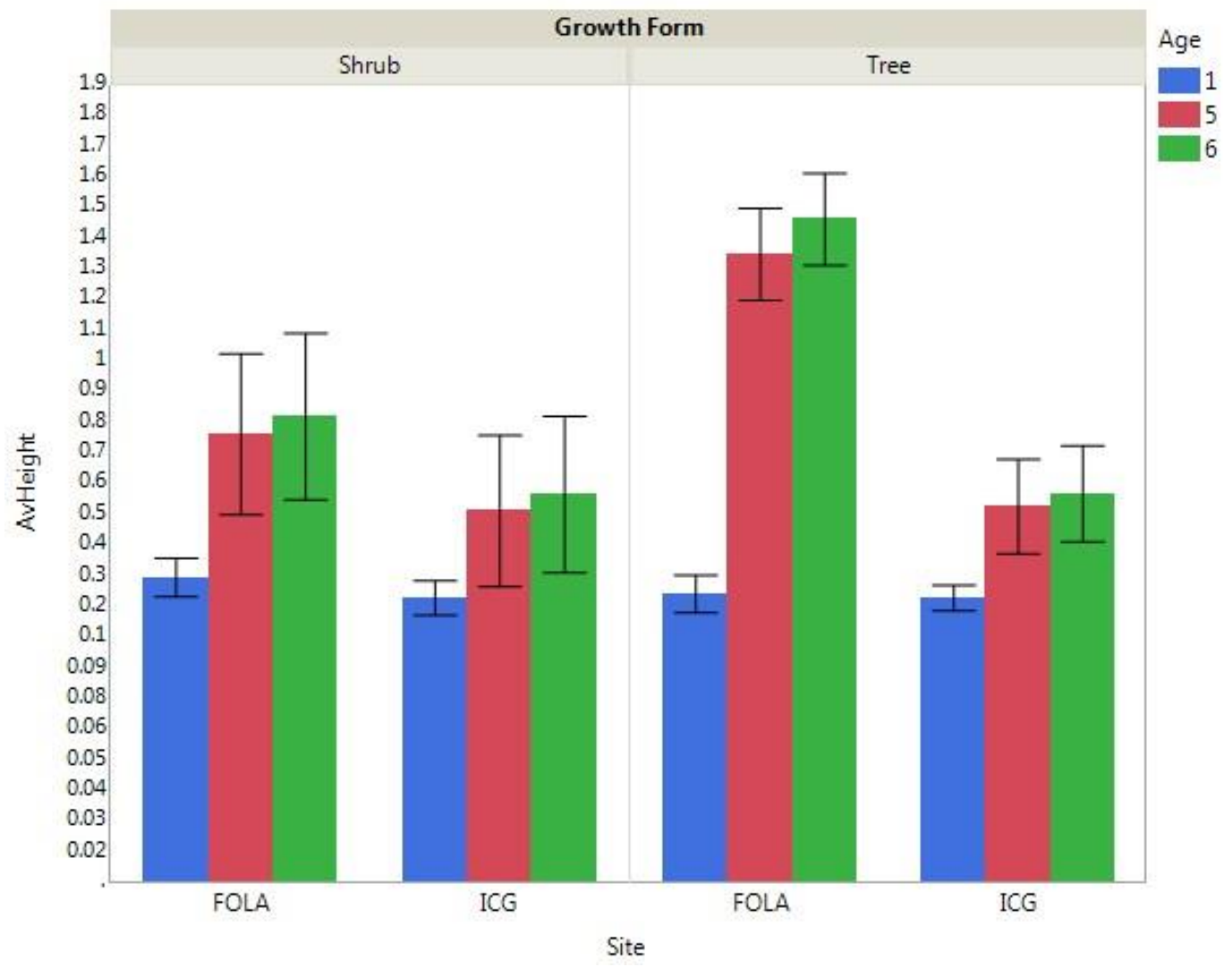

Figure 18. Average height of different growth forms separated by site (Fola and ICG) after 6 years of growth. 
Age proved to be significant for most of the species included in the study. This indicates that the planted species had been growing successfully on the sites planted in 2010. Exceptions where age was not significant included blueberry, eastern redbud, flowering dogwood, gray dogwood, hazelnut, pawpaw, and persimmon. These species did not have high survival percentages at these sites, and as a result the plants that survived had reduced average height.

Table 11. ANOVA results testing the effect of site on species height and the effect of the site*age interaction on the sites planted in 2010, Elk Run and ICG, using age as a repeated measure. The Tukey-Kramer adjustment was made to the calculated p-values in order to make the test more conservative and control type I errors from occurring.

\begin{tabular}{|c|c|c|c|c|c|c|c|c|c|c|c|c|c|c|}
\hline \multirow{3}{*}{ Species } & \multirow[t]{3}{*}{ Prob F } & \multicolumn{2}{|c|}{ Means by site } & \multirow{3}{*}{$\begin{array}{l}\text { p-value } \\
\text { p-value }\end{array}$} & \multirow[t]{3}{*}{ Prob F } & \multicolumn{6}{|c|}{$\begin{array}{l}\text { Least square means showing the effect of } \\
\text { SITE } * \text { AGE }\end{array}$} & \multirow{2}{*}{\multicolumn{3}{|c|}{$\begin{array}{c}\text { p-value } \\
\text { Fola and ICG }\end{array}$}} \\
\hline & & \multirow{2}{*}{ Fola } & \multirow{2}{*}{ ICG } & & & \multicolumn{3}{|c|}{ Fola } & \multicolumn{3}{|c|}{ ICG } & & & \\
\hline & & & & & & 1 & 5 & 6 & 1 & 5 & 6 & 1 & 5 & 6 \\
\hline $\begin{array}{l}\text { American } \\
\text { Crabapple }\end{array}$ & 0.95 & 0.78 & 0.80 & 0.95 & 0.53 & 0.35 & 0.80 & 1.20 & 0.07 & 1.10 & 1.25 & 0.96 & 0.97 & 1.00 \\
\hline Black Cherry & 0.56 & 1.40 & 1.67 & 0.56 & 0.78 & 0.40 & 1.85 & 1.95 & 0.38 & 2.27 & 2.37 & 1.00 & 0.97 & 0.97 \\
\hline $\begin{array}{l}\text { Black } \\
\text { Chokeberry }\end{array}$ & 0.04 & 0.95 & 0.74 & 0.04 & 0.74 & 0.55 & 1.10 & 1.20 & 0.38 & 0.87 & 0.97 & 0.33 & 0.17 & 0.18 \\
\hline Blueberry & 0.42 & - & 0.46 & - & - & 0.08 & - & - & 0.14 & 0.56 & 0.67 & 0.79 & - & - \\
\hline Chokecherry & 0.80 & 1.25 & 1.21 & 0.80 & 0.99 & 0.30 & 1.65 & 1.80 & 0.27 & 1.60 & 1.75 & 1.00 & 0.99 & 0.99 \\
\hline $\begin{array}{l}\text { Common } \\
\text { Apple }\end{array}$ & 0.05 & 1.33 & 0.97 & 0.05 & 0.12 & 0.55 & 1.70 & 1.75 & 0.60 & 1.12 & 1.18 & 0.99 & 0.14 & 0.15 \\
\hline Common Pear & 0.22 & 1.90 & 1.33 & 0.22 & 0.58 & 0.55 & 2.55 & 2.60 & 0.35 & 1.78 & 1.87 & 0.99 & 0.63 & 0.69 \\
\hline $\begin{array}{l}\text { Eastern } \\
\text { Redbud }\end{array}$ & 0.07 & 1.18 & 0.76 & 0.07 & 0.56 & 0.45 & 1.50 & 1.60 & 0.23 & 0.96 & 1.11 & 0.86 & 0.35 & 0.43 \\
\hline Elderberry & 0.40 & 0.68 & 0.76 & 0.40 & 0.47 & 0.05 & 0.95 & 1.05 & 0.04 & 1.00 & 1.25 & 1.00 & 0.99 & 0.70 \\
\hline $\begin{array}{l}\text { Flowering } \\
\text { Dogwood }\end{array}$ & 0.96 & 0.79 & 0.78 & 0.96 & 0.84 & 0.15 & 1.11 & 1.11 & 0.15 & 1.05 & 1.15 & 1.00 & 0.99 & 0.99 \\
\hline $\begin{array}{l}\text { Gray } \\
\text { Dogwood }\end{array}$ & 0.16 & 1.03 & 1.66 & 0.16 & 0.40 & 0.40 & 1.30 & 1.40 & 0.37 & 2.26 & 2.36 & 1.00 & 0.59 & 0.60 \\
\hline Hazelnut & 0.01 & 0.80 & 0.60 & 0.01 & 0.07 & 0.35 & 1.00 & 1.05 & 0.35 & 0.70 & 0.75 & 1.00 & 0.07 & 0.07 \\
\hline $\begin{array}{l}\text { Highbush } \\
\text { Cranberry }\end{array}$ & 0.16 & 1.03 & 1.62 & 0.16 & 0.23 & 0.25 & 1.40 & 1.45 & 0.22 & 2.26 & 2.36 & 1.00 & 0.44 & 0.39 \\
\hline Nannyberry & 0.17 & 1.15 & 0.94 & 0.17 & 0.63 & 0.35 & 1.50 & 1.60 & 0.27 & 1.22 & 1.32 & 0.99 & 0.61 & 0.61 \\
\hline Pawpaw & 0.15 & 0.43 & 0.56 & 0.15 & 0.36 & 0.09 & 0.50 & 0.90 & 0.15 & 0.94 & 0.80 & 0.98 & 0.46 & 0.94 \\
\hline Persimmon & 0.29 & 0.67 & 1.08 & 0.29 & 0.65 & 0.20 & 0.85 & 0.95 & 0.27 & 1.46 & 1.51 & 0.99 & 0.78 & 0.83 \\
\hline Red Mulberry & 0.71 & 1.25 & 1.37 & 0.71 & 0.58 & 0.25 & 1.70 & 1.80 & 0.35 & 2.10 & 1.65 & 0.99 & 0.95 & 0.99 \\
\hline Serviceberry & 0.12 & 1.28 & 1.06 & 0.12 & 0.03 & 0.03 & 1.85 & 1.95 & 0.27 & 1.41 & 1.51 & 0.52 & 0.19 & 0.19 \\
\hline $\begin{array}{l}\text { Washington } \\
\text { Hawthorn }\end{array}$ & 0.03 & 1.43 & 1.13 & 0.03 & 0.02 & 0.55 & 1.80 & 1.95 & 0.67 & 1.36 & 1.36 & 0.91 & 0.11 & 0.03 \\
\hline Wild Plum & 0.44 & 1.32 & 1.18 & 0.44 & 0.99 & 0.45 & 1.70 & 1.80 & 0.33 & 1.56 & 1.65 & 0.98 & 0.99 & 0.98 \\
\hline
\end{tabular}

In general, growth rates for trees were better at Fola compared to ICG. The effect of site was not significant for every tree species. Chokeberry, common apple, common pear, and eastern 
redbud displayed significant differences in average height between Fola and ICG. Red mulberry, serviceberry, Washington hawthorn, and wild plum all showed a difference in height between sites (Figure 18). The species which did not show a difference between sites was due to poor survival and poor growth in general. Unlike the trees, Fola did not appear to have greater shrub growth than ICG (Table 22). Hazelnut and nannyberry showed a significant effect with Fola having taller plants for these two species than ICG.

\section{Site and Soil Property Correlations to Height}

In order to attempt to correlate the average height of different species achieved in this study to the soil properties experienced at these sites, stepwise regression was used. The sites were split into two age groups, those planted in 2008 and those planted in 2010, and sites were only regressed against the other same-aged site. Out of the 20 species included in the study, few showed significant correlation between a soil/site parameter and average height achieved. On the older sites, Elk Run and Hobet, 11 species showed a significant correlation between their average heights and a site parameter. On the younger sites, ICG and Fola, eight species showed a significant correlation to species height and certain site parameters. The parameter with the most correlation to height was not the same at the different-aged sites for any species and the species that showed significance also changed between site ages (Tables 12 and 13). The most commonly correlated site parameter to species height was nickel at the older sites and copper at the younger sites. Due to inconsistencies, a principle component analysis was deemed more appropriate, although this analysis would not allow for separating the data by species.

Table 12. Results of stepwise regression on the sites planted in 2008 (Elk Run and Hobet) showing significant correlations between site parameters and average height by species. $(\mathrm{p} \leq 0.05$ = significant). Only 11 species showed significant correlations.

\begin{tabular}{|c|c|c|c|c|}
\hline & Variable & Estimate & Std.Err & Probability \\
\hline Black Cherry & $\mathrm{Cu}$ & 0.95 & 0.29 & 0.02 \\
\hline Blueberry & $\mathrm{pH}$ & 0.82 & 0.09 & 0.003 \\
\hline Common Pear & $\mathrm{Zn}$ & 0.41 & 0.32 & 0.01 \\
\hline \multirow{2}{*}{ Elderberry } & $\mathrm{Al}$ & -0.01 & 0.0029 & 0.02 \\
\cline { 2 - 5 } & $\mathrm{Ni}$ & -2.75 & 0.26 & 0.002 \\
\hline Flowering Dogwood & $\mathrm{Fe}$ & -0.11 & 0.26 & 0.002 \\
\hline Highbush Cranberry & $\mathrm{P}$ & -0.03 & 0.011 & 0.045 \\
\hline Nannyberry & $\mathrm{Al}$ & 0.02 & 0.0072 & 0.03 \\
\hline Persimmon & $\mathrm{Ni}$ & -2.59 & 0.51 & 0.007 \\
\hline
\end{tabular}




\begin{tabular}{|c|c|c|c|c|}
\hline Red Mulberry & $\mathrm{Ni}$ & -2.43 & 0.86 & 0.047 \\
\hline Washington & $\mathrm{EC}$ & -0.01 & 0.00096 & 0.0049 \\
\cline { 2 - 5 } Hawthorn & $\mathrm{Zn}$ & -0.61 & 0.036 & 0.0035 \\
\hline \multirow{3}{*}{ Wild Plum } & $\mathrm{Slope}$ & 0.02 & 0.00069 & 0.0019 \\
\cline { 2 - 5 } & $\mathrm{Na}$ & -49.91 & 0.55 & 0.0001 \\
\cline { 2 - 5 } & $\mathrm{Fe}$ & -0.0086 & 0.00010 & 0.0001 \\
\hline
\end{tabular}

Table 13. Results of stepwise regression on the sites planted in 2010 (ICG and Fola) showing significant correlations between site parameters and average height by species. $(\mathrm{p} \leq 0.05=$ significant). Only eight species showed significant correlations.

\begin{tabular}{|c|c|c|c|c|}
\hline \multirow{3}{*}{ Black Cherry } & Variable & Estimate & Std.Err & Probability \\
\cline { 2 - 5 } & $\mathrm{K}$ & 20.07 & 0.17 & $<.0001$ \\
\hline \multirow{2}{*}{ Common Apple } & $\mathrm{Fe}$ & 0.013 & 0.00025 & 0.0004 \\
\cline { 2 - 5 } & $\mathrm{Al}$ & 0.005 & 0.00032 & 0.0045 \\
\hline \multirow{2}{*}{ Common Pear } & $\mathrm{Mn}$ & 0.016 & 0.0021 & 0.016 \\
\cline { 2 - 5 } & $\mathrm{Ca}$ & -0.19 & 0.04 & 0.04 \\
\hline \multirow{2}{*}{ Eastern Redbud } & $\mathrm{Na}$ & 0.69 & 0.06 & 0.008 \\
\cline { 2 - 5 } & $\mathrm{Ni}$ & -1 & 0 & $<.0001$ \\
\hline Flowering Dogwood & $\mathrm{Cu}$ & 0.21 & 0.0040 & 0.01 \\
\hline \multirow{2}{*}{ Hazelnut } & $\mathrm{Mg}$ & 0.061 & 0.00042 & 0.004 \\
\cline { 2 - 5 } & $\mathrm{Al}$ & 0.0021 & 0.0000039 & 0.001 \\
\hline \multirow{2}{*}{ Persimmon } & $\mathrm{Cu}$ & 0.32 & 0.003 & 0.006 \\
\cline { 2 - 5 } & $\mathrm{Groundcover}$ & 0.0042 & 0.00016 & 0.02 \\
\hline Washington & Percent Fine & -0.01 & 0.0027 & 0.003 \\
\cline { 2 - 5 } Hawthorn & $\mathrm{Na}$ & 34.37 & 1.96 & 0.002 \\
\hline
\end{tabular}

Principle component analysis (PCA) followed by principle component regression (PCR) were used to determine which soil properties, both physical and chemical, most strongly correlated with plant height. First the soil conditions and normalized plant heights at all sites were analyzed together so as to represent the total variability of soil conditions experienced by plants in the study. The results of the PCA show the eigenvalues for the model and the score and loading plots of principle components 1 (PC1) and 2 (PC2), which together explained 58.4\% of the variability in the data. This variability is shown in the score plot on the left in Figure 19. The loading plot shows the scatterplot matrix of the loadings for each soil variable taken pairwise. The loading plot shows $\mathrm{pH}, \mathrm{K}, \mathrm{Mn}, \mathrm{Mg}, \mathrm{P}$, and $\mathrm{Cu}$ loading positively on PC1. Percent fines 
displayed a negative correlation on PC1. Figure 19 also displays those site factors that loaded on PC2 which are EC, $\mathrm{Al}$, and $\mathrm{Cu}$.
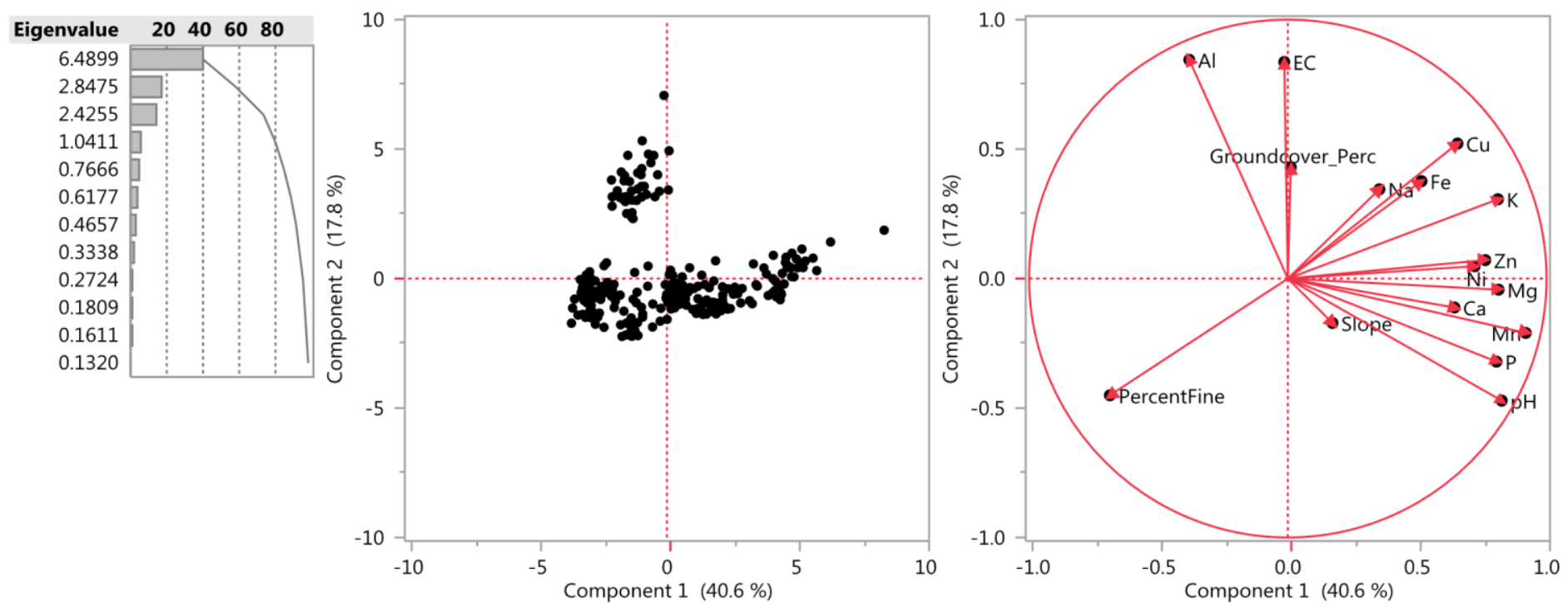

Figure 19. Principle components and correlation depictions on all sites.

The principle components (PC1-PC4) were then regressed against the average height. Four principle components were chosen based on the eigenvalues being $>1$, the percentage of variability accounted for by the first principle components, and the results of the scree plot which displayed significant bends at the first four points in the graph.

The regression results showed that the two strongest principle component groups were those on PC1 and PC2. These two groups showed significant p-values less than 0.05 (Table 14). The elements with the strongest eigenvector values for $\mathrm{PC} 1$ were $\mathrm{pH}, \mathrm{K}, \mathrm{Mg}, \mathrm{P}$, and $\mathrm{Mn}$. The soil properties with the strongest eigenvector values for PC2 were EC and Al. A regression was then run with these elements against average height to determine those soil properties most correlated with average height overall.

Table 14. Results of PCR of height at all sites in study. The $\mathrm{R}^{2}$ value of 0.15 was obtained.

\begin{tabular}{|l|c|c|c|c|c|}
\hline Term & Estimate & $\begin{array}{c}\text { Std } \\
\text { Error }\end{array}$ & $\begin{array}{c}\mathbf{t} \\
\text { Ratio }\end{array}$ & Prob>|t| & VIF \\
\hline $\begin{array}{l}\text { Interce } \\
\text { pt }\end{array}$ & 46.04 & 2.19 & 21.04 & $<.0001^{*}$ & $\cdot$ \\
\hline
\end{tabular}




\begin{tabular}{|l|c|c|c|c|c|}
\hline Prin1 & 3.14 & 0.79 & 3.97 & $0.0001^{*}$ & 1.02 \\
\hline Prin2 & 4.71 & 1.18 & 3.99 & $<.0001^{*}$ & 1.00 \\
\hline Prin3 & -1.45 & 1.19 & -1.23 & 0.2212 & 1.00 \\
\hline Prin4 & -2.25 & 2.02 & -1.11 & 0.2670 & 1.01 \\
\hline
\end{tabular}

The results of the principle components regression showed that the soil properties $\mathrm{K}, \mathrm{P}$, and $\mathrm{Al}$ as being significantly correlated to plant height considering all site conditions (Table 15). The $\mathrm{R}^{2}$ value, 0.20 , was fairly low.

Table 15. Results of PCR of all significant soil properties in PC 1 and 2 on average height for all sites. The $\mathrm{R}^{2}$ value of 0.20 was obtained. Only three properties were significant.

\begin{tabular}{|l|c|c|c|c|c|}
\hline Term & $\begin{array}{c}\text { Estimat } \\
\mathbf{e}\end{array}$ & $\begin{array}{c}\text { Std } \\
\text { Error }\end{array}$ & $\begin{array}{c}\mathbf{t} \\
\text { Ratio }\end{array}$ & $\begin{array}{c}\text { Prob>| } \\
\mathbf{t}\end{array}$ & VIF \\
\hline $\begin{array}{l}\text { Interce } \\
\mathrm{pt}\end{array}$ & 29.65 & 20.82 & 1.42 & 0.1561 & $\cdot$ \\
\hline $\mathrm{pH}$ & -4.48 & 4.43 & -1.01 & 0.3137 & 13.48 \\
\hline $\mathrm{EC}$ & -0.05 & 0.04 & -1.25 & 0.2129 & 3.03 \\
\hline $\mathrm{K}$ & 149.76 & 73.75 & 2.03 & $\begin{array}{c}0.0438 \\
*\end{array}$ & 3.86 \\
\hline $\mathrm{Mg}$ & 3.20 & 2.59 & 1.23 & $\begin{array}{c}0.2191 \\
4.08\end{array}$ \\
\hline $\mathrm{P}$ & 0.77 & 0.26 & 2.96 & 0.0035 & 5.89 \\
\hline $\mathrm{Al}$ & 0.14 & 0.06 & 2.27 & 0.0247 & 5.10 \\
& -0.26 & 0.22 & -1.16 & 0.2462 & 7.29 \\
\hline $\mathrm{Mn}$ & 3.68 & 7.33 & 0.50 & 0.6162 & 2.86 \\
\hline $\mathrm{Ni}$ & 0.21 & 1.66 & 0.13 & 0.9000 & 3.19 \\
\hline $\mathrm{Zn}$ & & & & & \\
\hline
\end{tabular}

The variability across sites was recognized both in the field and in the data collected from laboratory analysis of soil samples. The goal of the PCA in this study was to correlate certain soil properties or conditions with plant height, which was easier to do across sites with the same 
conditions. In order to determine how plants might grow in response to specific soil conditions experienced in the study, the data were separated by site. The data for each site was analyzed in the same way as when the data were analyzed when all site data were combined, with a PCA followed by a PCR.

\section{Elk Run}

The results of the PCA of site conditions on average height at Elk Run (Figure 20) showed different groupings on the score plot and different variables on different PCs than displayed in Figure 19. This indicated strong variability between sites included in the study. The score plot also showed distinct groupings at Elk Run, which indicated strong variability in site conditions as well. The data were not split up any further though, in order to not exclude experienced site conditions. The loading plot showed $\mathrm{pH}, \mathrm{Ca}, \mathrm{Mg}, \mathrm{Fe}$, and $\mathrm{Mn}$ as a part of PC1 and $\mathrm{Al}$ and $\mathrm{Cu}$ as a part of $\mathrm{PC} 2$.

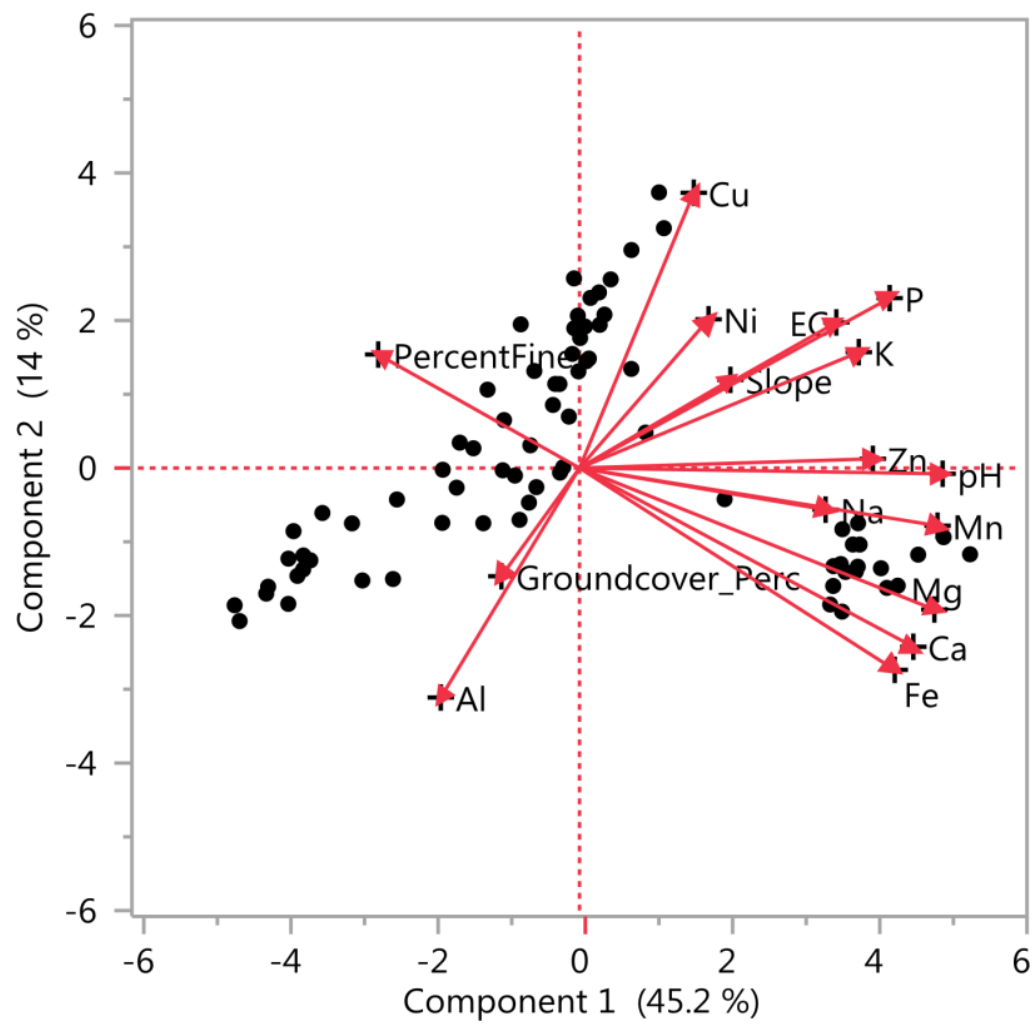

Figure 20. Biplot showing results of the PCA of soil conditions at Elk Run on average height of all trees and shrubs. 
Principle components (PC1-PC4) were then regressed against the average height at Elk Run. Four principle components were chosen based on the eigenvalues being $>1$, the percentage of variability accounted for by the first PC's, and the results of the scree plot which displayed significant bends at the first four points in the graph. The principle component group with the strongest correlation to average height at Elk Run was PC2 (Table 16). The two soil factors with the largest eigenvector values were $\mathrm{Cu}$ and $\mathrm{Al}$. The correlation between them and average height was then analyzed through PCR.

Table 16. Results of PCR of average height at Elk Run. The $\mathrm{R}^{2}$ value was 0.28.

\begin{tabular}{|l|c|c|c|c|}
\hline Term & Estimate & $\begin{array}{c}\text { Std } \\
\text { Error }\end{array}$ & t Ratio & Prob>|t| \\
\hline Intercept & 55.27 & 3.32 & 16.65 & $<.0001^{*}$ \\
\hline $\begin{array}{l}\text { Prin1 By } \\
\text { Site }\end{array}$ & 1.49 & 1.18 & 1.26 & 0.2128 \\
\hline $\begin{array}{l}\text { Prin2 By } \\
\text { Site }\end{array}$ & 8.14 & 2.21 & 3.68 & $0.0005^{*}$ \\
\hline $\begin{array}{l}\text { Prin3 By } \\
\text { Site }\end{array}$ & -6.01 & 3.08 & -1.95 & 0.0557 \\
\hline $\begin{array}{l}\text { Prin4 By } \\
\text { Site }\end{array}$ & -2.21 & 3.15 & -0.70 & 0.4859 \\
\hline $\begin{array}{l}\text { Prin5 By } \\
\text { Site }\end{array}$ & -6.81 & 3.43 & -1.98 & 0.0522 \\
\hline
\end{tabular}

The results of the PCR showed only $\mathrm{Cu}$ having a significant correlation to tree height at Elk Run when only those soil factors determined to be highly significant in PC2 were analyzed together (Table 17). The effect of $\mathrm{Cu}$ was then plotted against average height in a leverage plot (Figure 21), and the effect of copper seemed to have a positive correlation on average height at the Elk Run site. The relationship displayed in the leverage plot between $\mathrm{Cu}$ and average height was highly variable as seen by the width of the confidence intervals.

Table 17. Results of PCR of the soil properties from the significant PC2 (Table 8) on average height at Elk Run. Only copper was found to be significant. 


\begin{tabular}{|l|c|c|c|c|}
\hline Term & $\begin{array}{c}\text { Estimat } \\
\mathbf{e}\end{array}$ & $\begin{array}{c}\text { Std } \\
\text { Error }\end{array}$ & $\begin{array}{c}\mathbf{t} \\
\text { Ratio }\end{array}$ & Prob>|t| \\
\hline $\begin{array}{l}\text { Interce } \\
\mathrm{pt}\end{array}$ & 35.87 & 15.42 & 2.33 & $0.0235^{*}$ \\
\hline $\mathrm{Cu}$ & 16.58 & 6.02 & 2.75 & $0.0078^{*}$ \\
\hline $\mathrm{Al}$ & -0.17 & 0.13 & -1.31 & 0.1957 \\
\hline
\end{tabular}

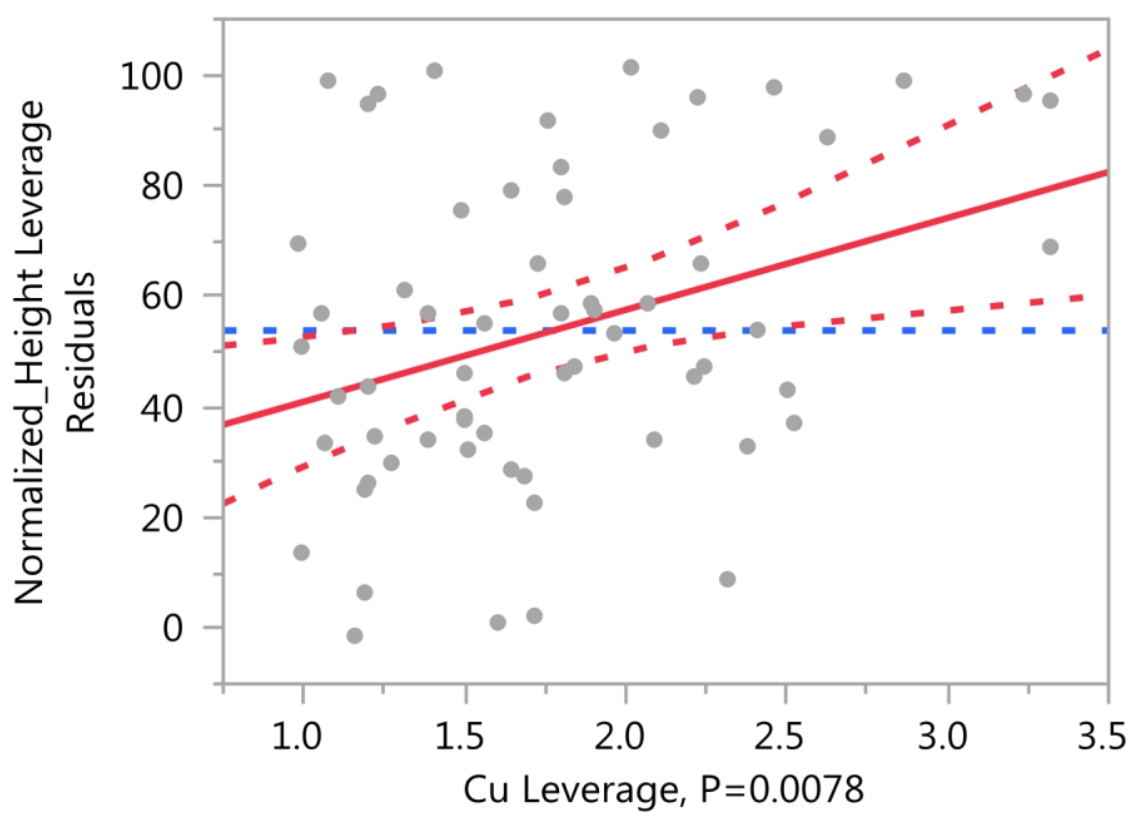

Figure 21. Leverage plot of the effect of $\mathrm{Cu}$ on average height at Elk Run.

\section{Hobet}

The results of the PCA at Hobet differed from those at Elk Run, Fola, and all sites, which again suggested the strong variability among sites for soil properties. Like Elk Run and Fola, groupings existed within the score plot, which indicated high variability within the site. The site factors that were part of $\mathrm{PC} 1$ were $\mathrm{pH}, \mathrm{Ca}, \mathrm{Mg}$, and $\mathrm{P}$ (Figure 22). Those that belonged to PC2 included slope, K, and Fe. PC3 included EC, Na, and Zn. 


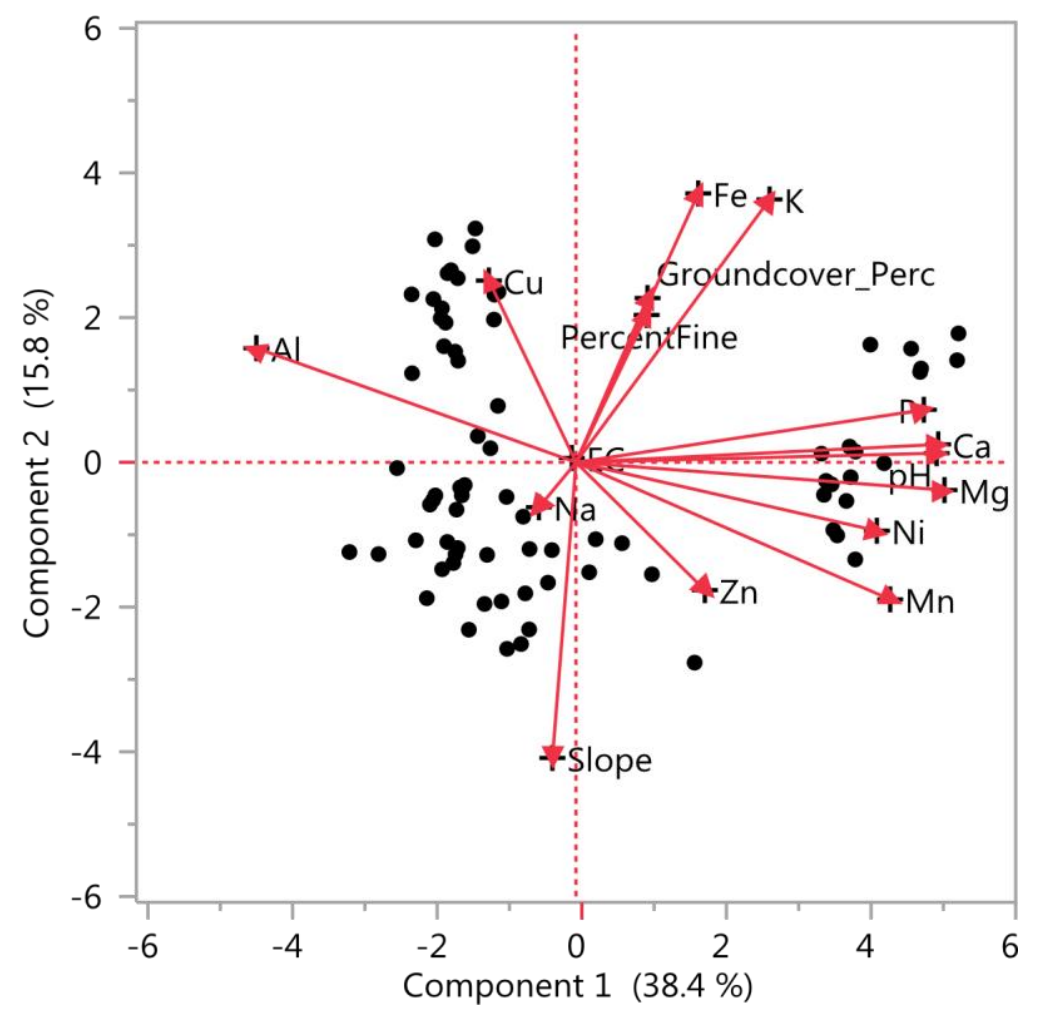

Figure 22. Biplot showing results of the PCA of soil conditions at Hobet on height.

The PCR run on the PCA results at Hobet showed PC3 to be most significantly correlated with average height (Table 18). To test which parameters within PC3 carried the most weight, the effect of each parameter was regressed against average height.

Table 18. Results of PCR of height at Hobet. A $R^{2}$ value of 0.22 was found.

\begin{tabular}{|l|c|c|c|c|}
\hline Term & Estimate & Std Error & t Ratio & Prob $>|\mathbf{t}|$ \\
\hline Intercept & 24.98 & 3.76 & 6.63 & $<.0001^{*}$ \\
\hline Prin1 By Site & 0.81 & 1.81 & 0.45 & 0.6572 \\
\hline Prin2 By Site & -4.13 & 3.16 & -1.30 & 0.2019 \\
\hline Prin3 By Site & 7.02 & 3.17 & 2.22 & $0.0341^{*}$ \\
\hline Prin4 By Site & -0.74 & 3.74 & -0.20 & 0.8432 \\
\hline Prin5 By Site & -6.98 & 3.55 & -1.97 & 0.0581 \\
\hline
\end{tabular}


The site parameters found to be important in the most significant PC group from the PCA did not prove to be correlated with average height when tested individually (Table 19). The level of significance chosen was less than or equal to 0.05, of which all elements included in Table 19 were above.

Table 19. Results of PCR of height at Hobet. The $\mathrm{R}^{2}$ value was 0.03 .

\begin{tabular}{|l|c|c|c|c|}
\hline Term & Estimate & Std Error & t Ratio & Prob>|t| \\
\hline Intercept & 13.25 & 15.81 & 0.84 & 0.4080 \\
\hline $\mathrm{EC}$ & 0.09 & 0.13 & 0.67 & 0.5060 \\
\hline $\mathrm{Na}$ & 171.67 & 394.74 & 0.43 & 0.6665 \\
\hline $\mathrm{Zn}$ & 2.92 & 12.18 & 0.24 & 0.8119 \\
\hline
\end{tabular}

\section{Fola}

The results of the PCA of site conditions on average height at Fola (Figure 23) showed different groupings on the score plot and different variables on different PCs than displayed in Figures 12 and 14. This again indicated strong variability between sites included in the study. Like Elk Run, there seemed to be large variability within Fola when looking at the biplot, because there were clumpings of different groups. At Fola, the soil parameters that belonged to PC1 were slope, percent fines, $\mathrm{pH}, \mathrm{EC}, \mathrm{K}$, while $\mathrm{Cu}, \mathrm{Ca}, \mathrm{Mg}, \mathrm{P}, \mathrm{Fe}$, and $\mathrm{Mn}$ belonged to PC2. Strong relationships also existed beyond PC1 and PC2. 


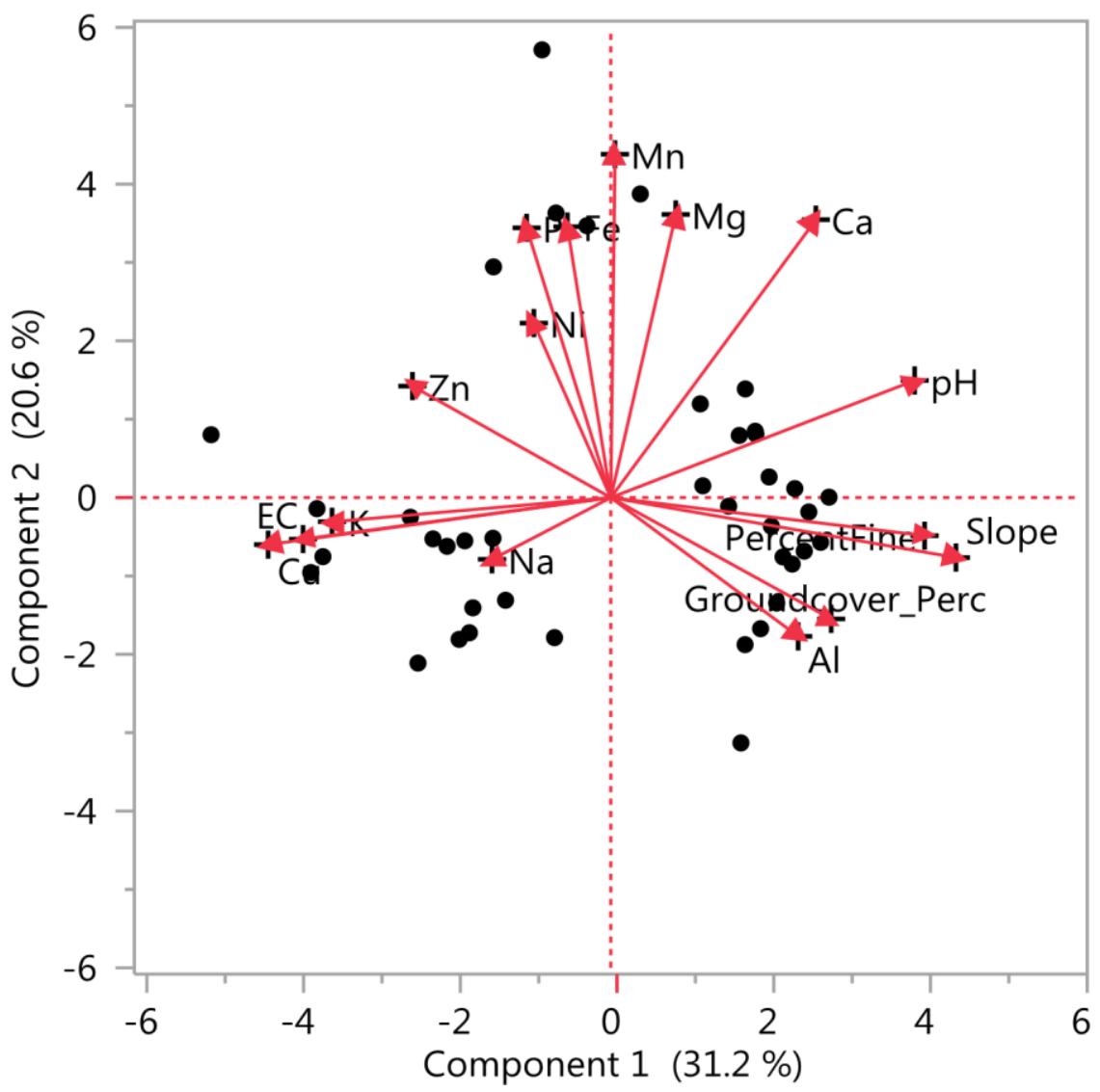

Figure 23. Biplot showing results of the PCA of soil conditions at Fola on height.

When PCR was used to analyze the PC groups found in the PCA at Fola, no group was found to be significantly correlated with average height at Fola (Table 20). The soil conditions were highly variable within the site, and there were only two blocks of data as opposed to four at the other sites. This made finding significant correlations between soil properties and height at Fola harder.

Table 20. Results of PCR of height at Fola. The $\mathrm{R}^{2}$ value was 0.05 .

\begin{tabular}{|l|c|c|c|c|}
\hline Term & Estimate & Std Error & t Ratio & Prob>|t| \\
\hline Intercept & 59.67 & 5.18 & 11.50 & $<.0001^{*}$ \\
\hline Prin1 By Site & 1.37 & 2.35 & 0.59 & 0.5630 \\
\hline Prin2 By Site & -2.72 & 2.85 & -0.95 & 0.3479 \\
\hline Prin3 By Site & -0.77 & 3.73 & -0.21 & 0.8373 \\
\hline
\end{tabular}




\begin{tabular}{|l|c|c|c|c|}
\hline Prin4 By Site & -1.10 & 5.03 & -0.22 & 0.8271 \\
\hline Prin5 By Site & 1.73 & 6.02 & 0.29 & 0.7749 \\
\hline
\end{tabular}

\section{ICG}

The same trends seen at the other sites were seen again in Figure 57 at ICG. At ICG, slope, percent fines, $\mathrm{K}, \mathrm{Mg}, \mathrm{P}, \mathrm{Mn}$, and $\mathrm{Cu}$ belonged to $\mathrm{PC}$, while $\mathrm{EC}, \mathrm{Ca}, \mathrm{Fe}, \mathrm{Ni}$, and groundcover were part of PC2 (Figure 24). The significance of the correlation of the different PC groups was tested using a PCR.

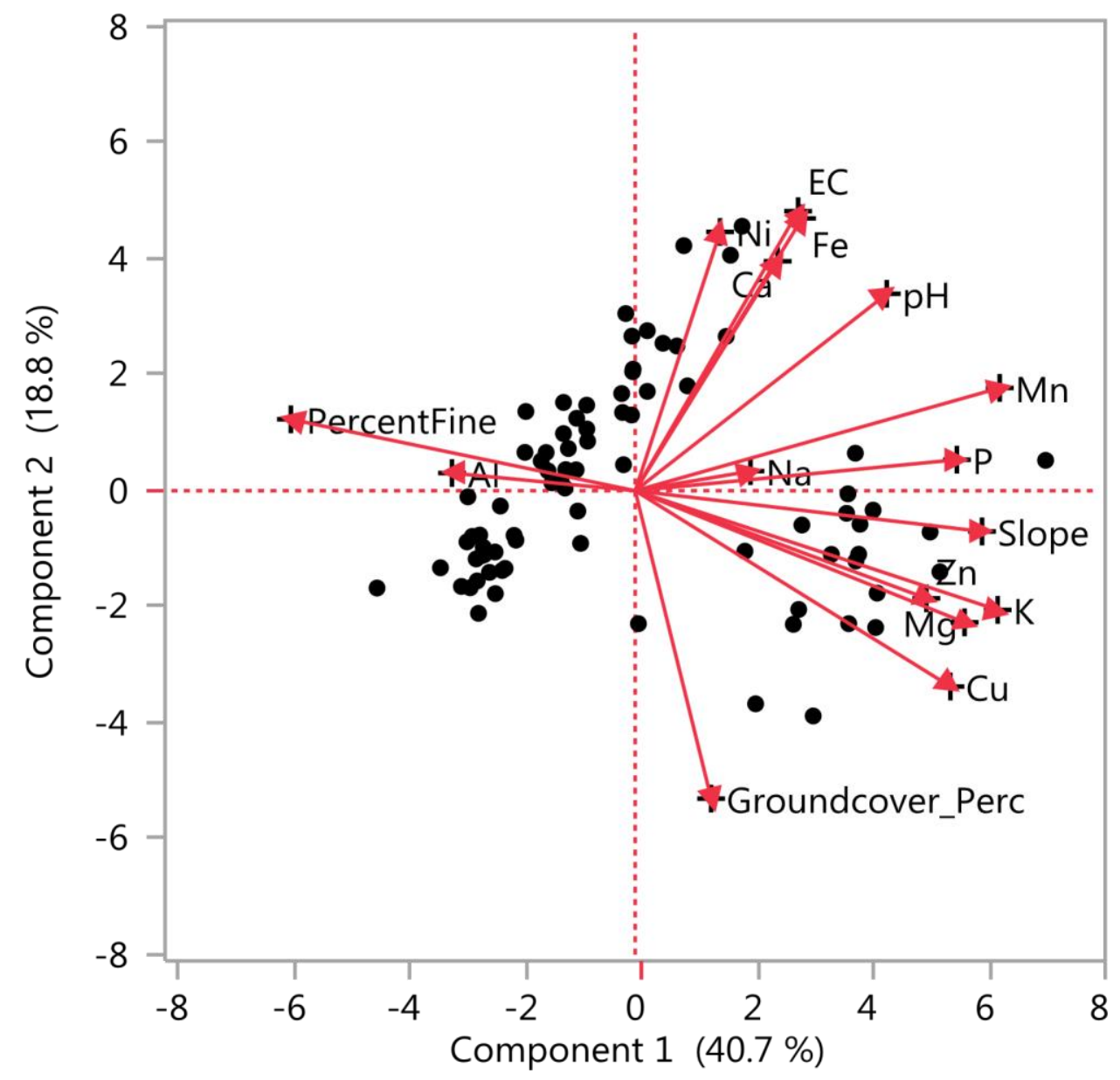

Figure 24. Biplot showing results of the PCA of soil conditions at ICG on height.

The PC1 group was found to be significantly correlated with average height at ICG (Table 21). Slope, percent fine, $\mathrm{K}, \mathrm{Mg}, \mathrm{P}, \mathrm{Mn}$, and $\mathrm{Cu}$ belong to $\mathrm{PC} 1$. These site parameters were 
regressed against average height alone in order to test their individual correlation to average height.

Table 21. Results of PCR of height at ICG. The $\mathrm{R}^{2}$ value was 0.34 .

\begin{tabular}{|l|c|c|c|c|}
\hline Term & Estimate & Std Error & t Ratio & Prob $>|\mathbf{t}|$ \\
\hline Intercept & 43.03 & 4.82 & 8.92 & $<.0001^{*}$ \\
\hline Prin1 By Site & 6.09 & 1.78 & 3.42 & $0.0014^{*}$ \\
\hline Prin2 By Site & -3.62 & 2.38 & -1.52 & 0.1355 \\
\hline Prin3 By Site & -3.34 & 4.32 & -0.77 & 0.4439 \\
\hline Prin4 By Site & 0.78 & 3.56 & 0.22 & 0.8276 \\
\hline Prin5 By Site & 1.77 & 4.36 & 0.41 & 0.6861 \\
\hline
\end{tabular}

When the correlation of significant components of PC1 were tested for significance to average height at ICG, only $\mathrm{Cu}$ was found to be significant (Table 22; Figure 25). This same significant positive relationship was found with $\mathrm{Cu}$ and average height at Elk Run (Figure 8; Table 24).

Table 22. Results of PCR of height at ICG. A R ${ }^{2}$ value of 0.45 was found.

\begin{tabular}{|l|c|c|c|c|}
\hline Term & Estimate & Std Error & t Ratio & Prob>|t| \\
\hline Intercept & -78.16 & 82.25 & -0.95 & 0.3478 \\
\hline Percent Fine & 0.68 & 0.94 & 0.72 & 0.4763 \\
\hline Slope & 1.72 & 1.36 & 1.26 & 0.2150 \\
\hline $\mathrm{K}$ & -318.96 & 187.41 & -1.70 & 0.0967 \\
\hline $\mathrm{Mg}$ & 16.70 & 16.73 & 1.00 & 0.3245 \\
\hline $\mathrm{P}$ & 0.47 & 0.65 & 0.72 & 0.4787 \\
\hline $\mathrm{Mn}$ & 0.23 & 0.47 & 0.50 & 0.6180 \\
\hline $\mathrm{Cu}$ & 10.92 & 5.31 & 2.05 & $0.0467 *$ \\
\hline
\end{tabular}




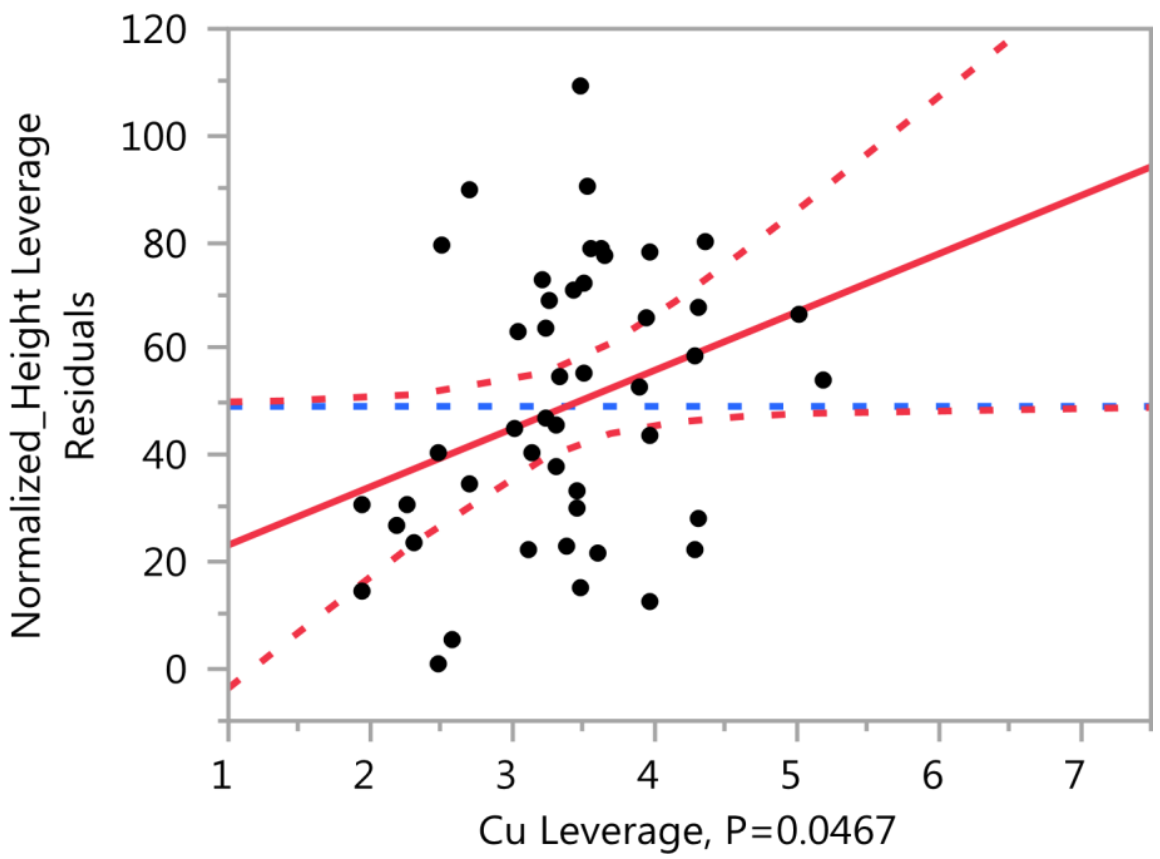

Figure 25. Leverage plot of the effect of $\mathrm{Cu}$ on average height at ICG.

\section{Discussion}

\section{Survival}

No significant difference was found between the survival data collected in 2015 and 2016. Significant differences were found for survival among different species included in the study, indicating that the response to growing in the reclaimed coal mine soils was species specific. Survival in 2016 across all species was $40 \%$. The species with the best survival 6 or 8 years after planting was black chokeberry with $56 \%$ survival. Only four other species had survival percentages over 50\%, and they were black cherry, Washington hawthorn, nannyberry, and hazelnut. Ten species had survival percentages between 40-49\%. Flowering dogwood and pawpaw had survival percentages $\leq 10 \%$, with significantly lower survival than the other species. Survival percentage significantly varied among sites overall; Elk Run showed the highest survival percentage (51\%) while Hobet had the lowest (25\%). Survival of the same species at the four different sites significantly varied for all species except black cherry and hazelnut. Both of these species were considered to be two of the best surviving species overall, and performed well across all sites. A significant effect was shown between survival for plants on the east- and westfacing aspects with the west (44\%) having overall greater survival than the east (36\%). The 
difference in survival between east- and west-facing aspects was very different for a few species in the study with the west-facing aspects having greater survival, which strongly influenced the statistical analysis. Black cherry, common pear, eastern redbud, hazelnut, highbush cranberry, nannyberry, persimmon, and red mulberry, however, showed a greater percentage alive on eastfacing blocks. Due to the conflicting results between the two aspects at the species level, the overall significant effect when all are combined is not very meaningful.

The effect of time on survival was tested for sites that were planted in the same year. On the older sites, Elk Run and Hobet, the shrubs had higher survival than the trees, with shrubs having about 5-10\% higher survival than trees, which effect persisted for the ensuing 8 years. Elk Run showed significantly higher survival (70-100\%) than Hobet (50-75\%) after the first year, and Elk Run had higher survival than Hobet 8 years later. Survival at both sites decreased over time, but the severity in survival decline over time varied among species. This result indicated that percent survival in the long run in reforestation and reclamation plantings is very dependent on the survival after the first growing season in the year of establishment. All species had greater than $50 \%$ survival after the first year, however only nannyberry, serviceberry, black cherry, and black chokeberry remained above $50 \%$ in 2016. Pawpaw did not have good survival in the study overall, and this poor survival is attributed to the species' need for deep and moist soil conditions in coves and under the canopy positions (Burns and Honkala, 1990). All of the best-surviving species belong to the Rosaceae family except for nannyberry, but all are considered to be semidrought tolerant and can survive in high solar conditions. The large percentage of mortality in other species was possibly due to poor planting stock, improper planting techniques, drought, or soil conditions experienced.

Shrubs were found to have higher survival than trees overall. Black chokeberry was found to have the best survival at year $1(100 \%)$ and in year $6(73 \%)$ for the shrubs while Washington hawthorn survived best out of the tree species with 100\% survival in year 1 and $80 \%$ remaining in year 6. Both black chokeberry and Washington hawthorn belong to the Rose family, thrive in full-sun conditions, and are considered to be drought tolerant. Blueberry experienced the most severe mortality of any species, and chokecherry, flowering dogwood, persimmon, serviceberry, and wild plum also fell below $50 \%$ survival by year 6 . The average site $\mathrm{pH}$ at ICG was 7.5, which is not conducive with blueberry's affinity for acidic soils. Flowering dogwood did not survive well on any site because of the need for moist and well-drained soils, and a 
requirement for shady conditions. Persimmon is most commonly found along moist floodplains, and the lack of soil moisture and organic matter in the reclaimed mine soils was probably responsible for the poor overall survival percentage. Serviceberry and chokecherry are commonly found in Appalachian forest ecosystems and in a variety of soil conditions, and the poor performance could not be directly correlated with species characteristics. Wild plum is found in a variety of soil conditions, but the species is notably drought intolerant and therefore would have difficulty surviving the dry mine soil conditions.

Weather conditions experienced by the plants in their year of establishment may have greatly influenced survival. In this study, Elk Run and Hobet were planted in 2008, while ICG and Fola were planted in 2010. The weather in the spring of 2008, the time of establishment, was described as normal for the season and state (NOAA, 2009). The summer of 2008 was warmer than normal for the country, but West Virginia experienced temperatures below normal. Fall of 2008 was described as cooler than normal in West Virginia, and the winter of 2008 was described as near normal for West Virginia. Rainfall received in the year 2008 was considered to be above normal in the spring, near normal in the summer, and below normal in the fall (NOAA, 2009).

The sites planted in the spring of 2010 experienced a much warmer than normal spring with normal precipitation (NOAA, 2011). The summer of 2010 was warmer than normal with a normal amount of precipitation. The fall of 2010 was hotter than average for West Virginia, while the amount of precipitation received during that time was below normal (NOAA, 2011). Stem girdling by rodents and browsing by wildlife could also have had a negative effect on survival. On the other hand, some species survived overall very well and had high survival rates across all sites. Chokecherry had the highest and most consistent survival across sites after the first growing season.

Survival percentages for this study were low compared to other reforestation studies in the past. Reasons for this may be due to planting stock quality, planting techniques, moisture conditions, soil conditions, or other site parameters. The absence of a shade canopy in the study area, which is required for some small tree and shrub species, may have also influenced the success of species survival in this study, especially those described as having a partial-shade requirement like pawpaw and flowering dogwood. The development of a canopy or shading of some type would be beneficial to many of these species by decreasing the amount of solar 
radiation received, decreasing soil temperature, and increasing the amount of moisture. Most of those species that require shade also require moist soil conditions to thrive.

Species which consistently experienced severe mortalities in the year of planting should not be included in reclamation plantings. These were flowering dogwood, blueberry, and pawpaw. For flowering dogwood and pawpaw, as described above, these species require more shade and moisture than can be expected or provided in reclamation plantings. Blueberry was successful at Hobet, but could not thrive at other places due to the requirement of very specific soil conditions. Species with greater than $50 \%$ survival in this study should be considered as potential candidates in future reclamation woody species plantings and include black chokeberry, black cherry, Washington hawthorn, nannyberry, and hazelnut. Greater survival was shown on west-facing aspects compared to the eastern facing aspects overall, but on the individual species level the results of the effect of aspect were conflicting. This effect was study specific, because greater survival was more commonly found on east-facing aspects where soil is thought to be moister and the amount of solar radiation received is more conducive with plant growth.

\section{Height}

In general, 18 of the 20 species included in this study were successful in growing on the reclaimed surface mine sites in West Virginia. The exceptions were pawpaw on the sites planted in 2008 and blueberry on the sites planted in 2010. When compared to the growth rates exhibited by these species in horticultural, forestry, or agricultural settings, the growth rate is considerably less in this project with these mine soil conditions. Growth between the two growth forms in 2016 after 6 and 8 years respectively was found to be not significantly different at Hobet and Elk Run, but was significantly different at ICG and Fola. At these sites planted in 2010, the tree species were significantly taller than the shrub species. Growth between sites differed, and plants at Hobet exhibited the worse overall growth when compared with Elk Run. When comparing the sites planted in 2010, Fola showed better growth than ICG. When all sites were compared together, Hobet had the smallest plants while Fola hosted the tallest. Heights between sites were not significantly different between Elk Run and Fola, which displayed significantly better height than the other two sites (Hobet and ICG). This result was surprising considering the two-year difference in planting times between Elk Run and Hobet and ICG and Fola, with Elk Run and Hobet planted in 2008. The Hobet site did have the worst survival percentages, which undoubtedly was reflected in average height as well. Most species displayed greater average 
heights on west-facing aspects when compared with east-facing aspects, but the difference in height was mostly insignificant and were masked by a couple of species having much greater height on the west-facing aspect. Only three species were found to have a significant aspect effect; common apple, flowering dogwood, and Washington hawthorn. For these species, height was significantly greater on west-facing blocks. The site with the most dramatic difference in aspect was Hobet, where the east-facing blocks were partially demolished in their first year of establishment. Elk Run and Fola both show the majority of trees being taller on the west-facing blocks compared to the east-facing blocks, but the effect is not significant. Contrarily at ICG, most tree species grew taller on the east-facing blocks but again the effect was not proven significant. For shrubs, Elk Run showed taller plants growing on east-facing blocks, while no significant difference was found at any other site.

\section{Soil and Site Conditions on Height}

Site and soil conditions examined in this study included slope, groundcover, percent fines, $\mathrm{pH}$, electrical conductivity, and macro- and micronutrients. The variation in these values across sites gave some perspective on how differences in these site qualities affected growth and survival at a species specific level.

Species survival and growth were affected by these site conditions although correlations between site and soil properties to tree and shrub height were difficult to interpret. For example, blueberry prefers acidic soils and will not thrive in alkaline conditions. Both conditions existed in this project, but the most acidic site, Fola, had the poorest blueberry survival with the highest blueberry survival at Hobet. The dry, upland conditions of the research blocks also affected the success of certain selected species including pawpaw and choke cherry, which generally prefer moist soil conditions. Additionally, growth of some of the selected species was affected by their degree of shade tolerance. Because this project was designed in a way that the planted species received direct solar radiation and had no canopy cover, species that require more shading did not thrive as well. And the east- or west-facing aspects at each site could also have impacted survival and growth of the planted species.

The Elk Run site had a moderate slope of 14\% (lower than ICG and Hobet), a neutral pH of 6.4 (higher than Hobet and Fola), and a low EC. It had the best survival for chokecherry, nannyberry, and American crabapple, but the lowest survival for flowering dogwood and a 
complete die-out of pawpaw. Using PCA and PCR analyses, the only site and soil factor that was positively correlated to tree and shrub height was copper concentration.

The Hobet mine site exhibited the worst overall survival and growth. Hobet had a slope of $22 \%$, a low $\mathrm{pH}$ of 4.5 , low EC, and high fines of $74 \%$. These soil characteristics are perceived to be compatible with tree and shrub growth; however, Hobet had the lowest survival for most of the species included in this study including red mulberry, black cherry, common apple, common pear, eastern redbud, gray dogwood, pawpaw, persimmon, Washington hawthorn, and wild plum. Like Elk Run, it also had a complete die-out of pawpaw. But, this site had the highest survival for blueberry and highbush cranberry. The results of the PCR at Hobet on the principle component groups developed in the PCA showed PC3 as having a significant correlation to plant height. PC3 included EC, $\mathrm{Na}$, and $\mathrm{Zn}$ as the important properties in that PC. However, when these site parameters were run separately to test for a significant correlation to plant height at Hobet, none were found.

The Fola mine site possessed a moderate slope, the lowest $\mathrm{pH}$ range, and the highest EC value of any site included in the study. This site achieved the highest survival for black chokeberry, hazelnut, Washington hawthorn, elderberry, common pear, and black cherry. Fola had the largest common pear trees of any site. Fola also showed the lowest survival for blueberry, choke cherry, and serviceberry. No site or soil parameters were correlated to tree and shrub height at Fola.

The ICG site had a slope of $23 \%$, the highest overall $\mathrm{pH}$ of 7.5 , low EC, and the lowest percent fines $(58 \%)$ of any site. ICG also had the least amount of groundcover competition overall. This site showed the highest survival for black cherry, common apple, common pear, eastern redbud, flowering dogwood, gray dogwood, pawpaw, persimmon, and Washington hawthorn. This same site exhibited the lowest survival for hazelnut, American crabapple, and black cherry. Copper was shown to be the only site parameter correlated with average height. The significant relationship between $\mathrm{Cu}$ and woody plant height at ICG was similar to the relationship found at Elk Run.

The soil properties at these sites were extremely variable and the PCA model correlating the site properties to average height of all plant species predicted only $58.4 \%$ of the variability. The PCR showed potassium, phosphorus, and aluminum as being the most strongly correlated with plant height when all four sites were considered. 


\section{Conclusions}

The survival of small trees and shrubs on surface mines in this study was lower than commercial tree plantings in many reforestation reclamation studies, which are often in the 60 to $80 \%$ range. Black chokeberry, black cherry, Washington hawthorn, nannyberry, and hazelnut were the only species out of the 20 included in this study with over $50 \%$ surviving in 2016. These species successfully established and persisted in this growing environment and should be considered in future reclamation reforestation plantings. In this study, survival in the year of establishment was a critical factor to the overall success of the species in later years. The difference in survival may be derived from the difference in species selection in this project when compared to other reforestation plantings. In most reforestation studies in Appalachia, hardwood tree species, with known survival success on surface mines, are used. This study evaluated small tree and shrub species that have not been planted on surface mines in a large scale and therefore knowledge and experience was not known about these species survival and growth on surface mines. Major reasons for these species high mortality were related to the conditions into which they were planted: high solar radiation, low levels of moisture, the absence of an existing forest canopy, and large amounts of browsing by wildlife during the first year of establishment when plants are most vulnerable. Some of the species in this study with high mortality were species more commonly found in moist cove environments like pawpaw and flowering dogwood. Other reasons for low survival in this study included a planting stock that may have been of poor quality and improper

planting techniques may have been used. Other un-identified reasons for poor success could also be responsible.

Although survival and some height measurements were found to be greater on west-facing aspects when compared with east-facing aspects in this study, the results were not strongly supported by statistical analyses and highly influenced by just a few species with better survival and growth on the west-facing aspect. The effect of aspect for the majority of species in this study was not significant at the individual species level. Most other reforestation studies document better survival and growth on east-facing aspects (Gorman, 2001; Chazdon, 2008; Fekedulegn 2002).

$\mathrm{K}, \mathrm{P}$ and $\mathrm{Al}$ were found to be soil properties correlated with average plant height across all sites and for all species. These results are not surprising because potassium and phosphorus are macronutrients, which are important for plant growth. Aluminum was a more surprising result, but it is closely connected with low $\mathrm{pH}$. When the soil properties of each individual site were correlated 
with average height, copper was found to have a significant positive correlation to plant height at Elk Run and ICG. Copper, unlike other soil nutrients, is not so easily linked to soil $\mathrm{pH}$ and explaining this height response to $\mathrm{Cu}$ is difficult (Sims, 1985). Soils with high $\mathrm{Cu}$ concentrations are generally due to fresh parent material containing copper minerals (Sims, 1985). In the reclamation setting, copper, as well as zinc and nickel are commonly solubilized upon the oxidation of sulfides following land disturbance and mining (Massey, 1971). If the $\mathrm{pH}$ is relatively low, these solubilized metals are highly available to plants in the soil system and may be taken up by plants excessively (Massey, 1971). Copper concentration may not be found to correlate so well with woody plant height in subsequent periods on these sites. As the mine soils mature and accumulate organic matter, copper will become less abundant and available for uptake by plants.

The results of this study will aid species selection for future reclamation plantings. Planting some of the more successful species in this study including black chokeberry, Washington hawthorn, black cherry, nannyberry, gray dogwood, hazelnut, and serviceberry would potentially encourage and accelerate ecological succession and benefit wildlife. Poor survival after 6 or 8 years as seen with some of the species on these sites provided strong evidence that planting may not be practical and a waste of resources. Additionally, to increase the survival of the species that are more adapted to shade and other more mature soil conditions and to save money, it may be advisable to delay transplanting of some of these species or to allow native recruitment of these species after a canopy has been established from the planted trees. Species that prefer cove environments and rely heavily on moist soil conditions and shade, like pawpaw, should not be included in these plantings. Therefore, based on the results of this study, careful attention should be taken when selecting species and sites where such plantings should occur.

\section{References}

Alday, J., V. Santana, R. Marrs, C. Martinez-Ruiz. 2014. Shrub-induced understory vegetation changes in reclaimed mines sites. Ecol. Engineer. 73: 691-698.

http://doi.org/10.1016/j.ecoleng.2014.09.079

Angel, P., V. Davis, J. Burger, D. Graves, and C. Zipper. 2005. The Appalachian Regional Reforestation Initiative. Forest Reclamation Advisory No. 1, December 2005.

Bise, J.B. 2013. Coal industry statistics. In: Modern American Coal Mining Methods and Applications. p. 1-23. Society for Mining, Metallurgy, and Exploration, Inc. Englewood, CO. 
Bowling, K.C., F.W. Schaller, P. Sutton. 1987. History of legislation for different states. p. 95116. In: Reclamation of Drastically Disturbed Lands. Am. Soc. Agron., Madison, Wisconsin.

Burger, J. 1999. Academic research perspective on experiences, trends, constraints, and needs related to reforestation of mined lands. p. 63-74. In: Proceedings, Enhancements of Reforestation of Surface Coal Mines: Technical Interactive Forum, March 23-24, 1999, Fort Mitchell, KY.

Burger, J., D. Graves, P. Angel, V. Davis, C. Zipper. 2005. The forestry reclamation approach. ARRI forest reclamation advisory number 2. U.S. Office of Surface Mining, Department of Interior, Washington. http://arri.osmre.gov/FRA/Advisories/FRA_No.2.71807.Revised.pdf. Accessed 17 November 2016.

Burger, J., and C. Zipper. 2011. Reforestation guidelines for unused surface mineland in the eastern United States. Virginia Coop. Ext. Publ. 460-144. Virginia Tech, Blacksburg, VA. http://www.prp.cses.vt.edu/Update-PrePubs/460-144-prepub.pdf. Accessed 19 November 2016.

Burns, R.M. and B.H. Honkala. 1990. Silvics of North America, Vol. 2, Hardwoods. Washington DC: U.S.D.A. Forest Service Agriculture Handbook 654. http://www.na.fs.fed.us/pubs/silvics_manual/table_of_contents.shtm, last accessed 12.15.2016.

CBG. 2016. Plant Profiles. Chicago Botanic Garden. http://www.chicagobotanic.org/plantinfo/pp/. 15 Dec 2016.

Chazdon, R. 2008. Beyond deforestation: restoring forests and ecosystem services on degraded lands. Science 320: 1458-1460. DOI: 10.1126/science.1155365

Emerson et al. 2009. Survival and growth of native hardwoods in brown vs gray sandstone on a reclaimed surface mine in West Virginia. J Environ Qual 38: 1821-1829.

Emerson, P., and J. Skousen. 2009. Release of nutrients from brown and gray sandstone soil substrates in southern West Virginia. p. 1135-1143. In: Proceedings of the 2010 National Meeting of American Society of Mining and Reclamation, Pittsburgh, PA, June 5-11. June 2010. ASMR, Lexington, KY.

Fekedulegn, D., R. Hicks, J.J Colbert. 2002. Influence of topographic aspect, precipitation, and drought on radial growth of four major tree species in an Appalachian watershed. Forest Ecol. Manage. 6064: 1-17.

Franklin, J., C. Zipper, J. Burger, J. Skousen, D. Jacobs. 2012. Influence of herbaceous ground cover on forest restoration of eastern US Coal surface mines. New For. 43: 905-924.

Gorman, J., J. Skousen, J Sencindiver, P. Ziemkiewicz. 2001. Forest productivity and minesoil development under a white pine plantation versus natural vegetation after 30 years. p. 19. In: Proceedings, 2001 American Society of Mining and Reclamation. June 3-7, 2001. Lexington, KY.

Haering, K.C., W.L. Daniels, J.M. Galbraith. 2004. Appalachian mine soil morphology and properties: effects of weathering and mining method. Soil Sci. Soc. Am. J. 68: 13151325. 
Huges, H.G. 1987. Use of native shrubs on strip-mined lands in the humid east. p. 70-74. In: The Symposium on Shrub Ecophysiology and Biotechnology, Logan, UT, June 30- July 2, 1987.

http://www.apps.dcnr.state.pa.us/conservationscience/grantreports/GrantReports/897328/ 897328_report.pdf. Accessed 19 November 2016.

IWF. 2016. Apple. Illinois Wild Flowers.

http://www.illinoiswildflowers.info/trees/plants/apple.html 15 Dec 2016.

Macdonald, E., S. Landhauser, J. Skousen, J. Franklin, J. Froux, S. Hall, D. Jacobs, S. Quideau. 2015. Forest restoration following surface mining disturbance: challenges and solutions. New Forest 46: 703.doi:10.1007/s11056-015-9506-4

Massey, H.F. Barnhisel, R.I. 1971. Copper, nickel, and zinc released from acid coal mine spoil materials of eastern Kentucky. Soil Sci. Soc. Am. J. 113 207-212.

MBG. 2016. Pyrus communis. Missouri Botanical Garden.

http://www.missouribotanicalgarden.org/PlantFinder/PlantFinderDetails.aspx?kempercod $\underline{\mathrm{e}=\mathrm{a} 897.15 \text { December } 2016 .}$

NOAA National Centers for Environmental Information, State of the Climate: National Overview for Annual 2010, published online January 2011, retrieved on February 28, 2017 from http://www.ncdc.noaa.gov/sotc/national/201013.

NOAA National Centers for Environmental Information, State of the Climate: National Overview for Annual 2008, published online January 2009, retrieved on February 28, 2017 from http://www.ncdc.noaa.gov/sotc/national/200813.

Plass, W.T. 2000. History of surface mining reclamation and associated legislation. p. 1-20. In: R.I. Barnhisel et al. (eds) Reclamation of Drastically Disturbed Lands. Am. Soc of Agron. Madison, WI.

Sims, J. T. 1986. Soil pH effects on the distribution and plant availability of manganese, copper, and zinc1. Soil Sci. Soc. Am. J. 50:367-373. doi:10.2136/sssaj1986.03615995005000020023x

Skousen, J., and C. Zipper. 2014. Post-mining policies and practices in the eastern USA coal region. International Journal of Coal Science and Technology 1: 135151. doi:10.1007/s40789-014-0021-6

Statistical Analysis System. 2011. SAS/STAT systems for windows v.9.3. SAS Institute, Cary, NC.

Swanson, Mark E., J. Franklin, R. Beschta, C. Crisafulli, D. DellaSala, R. Hutto, D. Lindenmayer, F. Swanson. 2010. The forgotten state of forest succession: early-succesional ecosystem on forest sites. Frontiers in Ecology and the Environment 9: 117-125. http://onlinelibrary.wiley.com/doi/10.1890/090157/abstract

Torbert, J.L., and J.A. Burger. 2000. Forest land reclamation. p. 371-398. In: R.I. Barnhisel et al. (eds) Reclamation of Drastically Disturbed Lands. Ameri Soc of Agron. Madison, WI.

Turner, M., W. Baker, C. Peterson, R. Peet. 1998. Factors influencing succession: lessons from large, infrequent natural disturbances. Ecosystems 1: 511-523. 


\section{http://dx.doi.org/10.1007/s100219900047}

USDA, NRCS. 2016. The PLANTS Database. http://plants.usda.gov. 15 Dec 2016. National Plant Data Team, Greensboro, NC 27401-4901 USA.

Vogel, W., R. Thompson, G. Wade. 1981. Success of trees and shrubs in an 18-year old planting on mine spoil. Res. Pap. NE-567. Broomall, PA: US Department of Agriculture, Forest Service, Northeastern Forest Experiment Station; 1985. http://www.fs.fed.us/ne/newtown_square/publications/research_papers/pdfs/scanned/ne_r p567p.pdf. Accessed 19 November 2016.

Wilkinson, Antoinette Miele. 1948. Floral Anatomy and Morphology of Some Species of the Tribes Linnaeeae and Sambuceae of the Caprifoliaceae. American Journal of Botany 35:7. 365-371. www.jstor.org/stable/2437935.

Wilson-Kokes, L., et al. 2013. Hardwood tree growth after eight years on brown and gray mine soils in West Virginia. J Env Qual 42: 1353-1362.

Zipper, C., J. Burger, C. Barton, and J. Skousen. 2013. Rebuilding soils for forest restoration on Appalachian mined lands. Soil Sci. Soc. Am. J. 77: 337-349.

\section{http://dx.doi.org/10.2136/sssaj2012.0335}

Zipper, C., J. Burger, J. Skousen, P. Angel, C. Barton, V. Davis, and J. Franklin. 2011. Restoring forests and associated ecosystem services on Appalachian coal surface mines. Environ. Management 47: 751-765. http://dx.doi.org/10.1007/s00267-011-9670-z 


\section{Appendix}

\section{Height ANOVA Tables}

Table 4A. ANOVA results testing the effect of age on species height on the sites planted in 2008, Elk Run and Hobet using age as a repeated measure. The Tukey-Kramer adjustment was made to the calculated p-values in order to make the test more conservative and control type I errors from occurring.

\begin{tabular}{|c|c|c|c|c|c|c|c|c|}
\hline \multirow[b]{2}{*}{ Species } & \multirow[b]{2}{*}{ Effect } & \multirow[b]{2}{*}{ ProbF } & \multicolumn{3}{|c|}{ Least square means by age } & \multicolumn{3}{|c|}{$\begin{array}{l}\text { p-values with Tukey-Kramer adjustment showing } \\
\text { the effect of AGE }\end{array}$} \\
\hline & & & 1 & 7 & 8 & Year $1 \& 7$ & Year $1 \& 8$ & Year $7 \& 8$ \\
\hline American Crabapple & Age & $<0.0001$ & 0.20 & 1.03 & 1.07 & $<0.0001$ & $<0.0001$ & 0.72 \\
\hline Black Cherry & Age & 0.0002 & 0.76 & 1.74 & 1.70 & 0.0002 & 0.0003 & 0.87 \\
\hline Black Chokeberry & Age & 0.008 & 0.36 & 0.78 & 0.83 & 0.01 & 0.007 & 0.66 \\
\hline Blueberry & Age & $<0.0001$ & 0.19 & 0.77 & 0.87 & $<0.0001$ & $<0.0001$ & 0.07 \\
\hline Chokecherry & Age & $<0.0001$ & 0.39 & 1.37 & 1.42 & $<0.0001$ & $<0.0001$ & 0.71 \\
\hline Common Apple & Age & $<0.0001$ & 0.31 & 1.0 & 1.10 & $<0.0001$ & $<0.0001$ & 0.13 \\
\hline Common Pear & Age & 0.0001 & 0.22 & 1.61 & 1.65 & 0.0001 & 0.0001 & 0.93 \\
\hline Eastern Redbud & Age & 0.005 & 0.44 & 1.25 & 1.29 & 0.005 & 0.004 & 0.90 \\
\hline Elderberry & Age & $<0.0001$ & 0.23 & 0.98 & 1.12 & $<0.0001$ & $<0.0001$ & 0.11 \\
\hline Flowering Dogwood & Age & 0.0150 & 0.47 & 0.94 & 1.16 & 0.08 & 0.01 & 0.21 \\
\hline Gray Dogwood & Age & $<0.0001$ & 0.41 & 1.78 & 1.91 & $<0.0001$ & $<0.0001$ & 0.36 \\
\hline Highbush Cranberry & Age & 0.0002 & 0.37 & 1.47 & 1.53 & 0.0002 & 0.0002 & 0.75 \\
\hline Nannyberry & Age & $<0.0001$ & 0.39 & 1.50 & 1.57 & $<0.0001$ & $<0.0001$ & 0.37 \\
\hline Pawpaw & Age & N/A & 0.36 & - & - & - & - & - \\
\hline Persimmon & Age & $<0.0001$ & 0.37 & 1.42 & 1.48 & $<0.0001$ & $<0.0001$ & 0.58 \\
\hline Red Mulberry & Age & 0.0056 & 0.50 & 1.26 & 1.30 & 0.005 & 0.005 & 0.85 \\
\hline Serviceberry & Age & $<0.0001$ & 0.38 & 1.59 & 1.74 & $<0.0001$ & $<0.0001$ & 0.74 \\
\hline Washington Hawthorn & Age & 0.0004 & 0.39 & 1.41 & 1.47 & 0.0004 & 0.0004 & 0.83 \\
\hline Wild Plum & Age & 0.0007 & 0.71 & 1.53 & 1.59 & 0.0008 & 0.0005 & 0.73 \\
\hline
\end{tabular}


Table 4A. ANOVA results testing the effect of site and aspect, their interaction on species height in 2016 only on the sites planted in 2008 , Elk Run and Hobet with age used as a repeated measure. The Tukey-Kramer adjustment was made to the calculated p-values in order to make the test more conservative and control type I errors from occurring.

\begin{tabular}{|c|c|c|c|c|c|c|c|c|c|c|c|c|c|c|c|c|c|c|}
\hline \multirow[b]{3}{*}{ Species } & \multirow[b]{3}{*}{ Effect } & \multirow[b]{3}{*}{ ProbF } & \multirow{2}{*}{\multicolumn{2}{|c|}{$\begin{array}{l}\text { Least square } \\
\text { means by site }\end{array}$}} & \multirow{3}{*}{$\begin{array}{c}\text { p-values } \\
\text { with Tukey- } \\
\text { Kramer } \\
\text { adjustment } \\
\text { showing the } \\
\text { effect of } \\
\text { SITE } \\
\\
\text { p-value }\end{array}$} & \multirow[b]{3}{*}{ Effect } & \multirow[b]{3}{*}{ ProbF } & \multirow{2}{*}{\multicolumn{2}{|c|}{$\begin{array}{c}\text { Least square } \\
\text { means by } \\
\text { aspect }\end{array}$}} & \multirow{3}{*}{$\begin{array}{c}\text { p-values } \\
\text { with Tukey- } \\
\text { Kramer } \\
\text { adjustment } \\
\text { showing the } \\
\text { effect of } \\
\text { ASPECT } \\
\\
\text { p-value }\end{array}$} & \multirow[b]{3}{*}{ Effect } & \multirow[b]{3}{*}{ ProbF } & \multicolumn{4}{|c|}{$\begin{array}{l}\text { Least square means by } \\
\text { site*aspect }\end{array}$} & \multicolumn{2}{|c|}{$\begin{array}{c}\text { p-values with } \\
\text { Tukey-Kramer } \\
\text { adjustment } \\
\text { showing the } \\
\text { effect of } \\
\text { SITE*ASPECT }\end{array}$} \\
\hline & & & & & & & & & & & & & \multicolumn{2}{|c|}{ Elk Run } & \multicolumn{2}{|c|}{ Hobet } & \multirow[b]{2}{*}{ East } & \multirow[b]{2}{*}{ West } \\
\hline & & & $\begin{array}{l}\text { Elk } \\
\text { Run } \\
\end{array}$ & Hobet & & & & East & West & & & & East & West & East & West & & \\
\hline $\begin{array}{l}\text { American } \\
\text { Crabapple }\end{array}$ & Site & 0.40 & 0.79 & 0.46 & 0.40 & Aspect & 0.76 & 0.68 & 0.57 & 0.76 & Site*aspect & 0.75 & 0.91 & 0.67 & 0.46 & 0.47 & 0.37 & 0.81 \\
\hline Black Cherry & Site & 0.71 & 1.30 & 1.16 & 0.72 & Aspect & 0.93 & 1.21 & 1.24 & 0.73 & Site*aspect & 0.76 & 1.34 & 1.25 & 1.08 & 1.23 & 0.18 & 0.99 \\
\hline $\begin{array}{l}\text { Black } \\
\text { Chokeberry }\end{array}$ & Site & 0.45 & 0.58 & 0.40 & 0.45 & Aspect & 0.98 & 0.48 & 0.50 & 0.98 & Site*aspect & 0.45 & 0.67 & 0.49 & 0.30 & 0.49 & - & 0.48 \\
\hline Blueberry & Site & 0.43 & 0.30 & 0.52 & 0.43 & Aspect & 0.60 & 0.34 & 0.48 & 0.60 & Site*aspect & 0.51 & 0.59 & 0.12 & 0.14 & 0.08 & - & - \\
\hline Chokecherry & Site & 0.40 & 1.04 & 0.71 & 0.40 & Aspect & 0.64 & 0.96 & 0.78 & 0.64 & Site*aspect & 0.80 & 0.03 & 0.06 & 0.12 & 0.12 & 0.69 & 0.61 \\
\hline $\begin{array}{l}\text { Common } \\
\text { Apple }\end{array}$ & Site & 0.87 & 0.59 & 0.55 & 0.87 & Aspect & 0.15 & 0.38 & 0.76 & 0.15 & Site*aspect & 0.70 & 0.25 & 0.01 & 0.14 & 0.02 & - & 0.50 \\
\hline Common Pear & Site & 0.63 & 1.08 & 0.71 & 0.63 & Aspect & 0.98 & 0.89 & 0.91 & 0.98 & Site*aspect & 0.62 & 0.15 & 0.24 & 0.57 & 0.35 & 0.37 & 0.99 \\
\hline $\begin{array}{l}\text { Eastern } \\
\text { Redbud }\end{array}$ & Site & 0.40 & 0.95 & 0.54 & 0.40 & Aspect & 0.72 & 0.83 & 0.66 & 0.72 & Site*aspect & 0.92 & 0.05 & 0.08 & 0.37 & 0.27 & 0.37 & 0.99 \\
\hline Elderberry & Site & 0.52 & 0.67 & 0.45 & 0.52 & Aspect & 0.61 & 0.48 & 0.65 & 0.61 & Site*aspect & 0.33 & 0.03 & 0.06 & 0.20 & 0.71 & - & 0.60 \\
\hline $\begin{array}{l}\text { Flowering } \\
\text { Dogwood }\end{array}$ & Site & 0.82 & 0.74 & 0.68 & 0.82 & Aspect & 0.46 & 0.61 & 0.81 & 0.46 & Site*aspect & 0.17 & 0.83 & 0.65 & 0.40 & 0.96 & - & 0.33 \\
\hline $\begin{array}{l}\text { Gray } \\
\text { Dogwood }\end{array}$ & Site & 0.84 & 1.20 & 1.32 & 0.84 & Aspect & 0.31 & 1.61 & 0.91 & 0.31 & Site*aspect & 0.68 & 1.41 & 0.98 & 1.80 & 0.84 & 0.86 & 0.77 \\
\hline $\begin{array}{l}\text { Highbush } \\
\text { Cranberry }\end{array}$ & Site & 0.26 & 1.05 & 0.5 & 0.26 & Aspect & 0.79 & 0.84 & 0.72 & 0.79 & Site*aspect & 0.98 & 1.12 & 0.98 & 0.56 & 0.45 & 0.02 & - \\
\hline Nannyberry & Site & 0.36 & 1.06 & 0.68 & 0.36 & Aspect & 0.82 & 0.92 & 0.83 & 0.82 & Site*aspect & 0.97 & 1.11 & 1.01 & 0.72 & 0.65 & 0.59 & 0.72 \\
\hline Pawpaw & Site & 0.10 & 0.33 & 0.40 & 0.10 & Aspect & 0.50 & 0.37 & 0.35 & 0.50 & Site*aspect & 0.50 & 0.35 & 0.30 & 0.40 & 0.40 & - & - \\
\hline Persimmon & Site & 0.28 & 0.99 & 0.50 & 0.28 & Aspect & 0.98 & 0.74 & 0.75 & 0.98 & Site*aspect & 0.67 & 1.09 & 0.91 & 0.40 & 0.60 & - & 0.52 \\
\hline Red Mulberry & Site & 0.44 & 1.01 & - & - & Aspect & 0.69 & - & 0.71 & - & Site*aspect & - & 1.11 & 0.92 & - & 0.50 & - & 0.81 \\
\hline Serviceberry & Site & 0.53 & 1.26 & 0.91 & 0.53 & Aspect & 0.66 & 1.20 & 0.96 & 0.66 & Site*aspect & 0.69 & 1.27 & 1.25 & 1.14 & 0.68 & 0.66 & 0.04 \\
\hline $\begin{array}{l}\text { Washington } \\
\text { Hawthorn }\end{array}$ & Site & 0.46 & 1.00 & 0.61 & 0.46 & Aspect & 0.78 & 0.74 & 0.88 & 0.78 & Site*aspect & 0.59 & 1.07 & 0.93 & 0.40 & 0.82 & - & 0.91 \\
\hline Wild Plum & Site & 0.10 & 1.27 & 0.73 & 0.10 & Aspect & 0.97 & 1.00 & 0.99 & 0.97 & Site*aspect & 0.57 & 1.36 & 1.18 & 0.65 & 0.80 & - & 0.29 \\
\hline
\end{tabular}


Table 4A. ANOVA results testing the effect of site and aspect, their interaction on growth form height in 2016 only on the sites planted in 2008, Elk Run and Hobet with age used as a repeated measure. The Tukey-Kramer adjustment was made to the calculated p-values in order to make the test more conservative and control type I errors from occurring.

\begin{tabular}{|l|c|c|c|}
\hline Effect & Pr $>$ F & \multicolumn{2}{|c|}{ Least square means } \\
\hline Growth form & 0.75 & Shrub & Tree \\
\hline $\begin{array}{l}\text { Species within growth } \\
\text { form }\end{array}$ & $<0.0001$ & 1.30 & 1.33 \\
\cline { 1 - 2 } Site & 0.015 & & \\
\hline
\end{tabular}


Table 4A. ANOVA results testing the effect of age on species height on the sites planted in 2010, Fola and ICG using age as a repeated measure. The Tukey-Kramer adjustment was made to the calculated p-values in order to make the test more conservative and control type I errors from occurring.

\begin{tabular}{|c|c|c|c|c|c|c|c|c|}
\hline \multirow[b]{2}{*}{ Species } & \multirow[b]{2}{*}{ Effect } & \multirow[b]{2}{*}{ ProbF } & \multicolumn{3}{|c|}{ Least square means by age } & \multicolumn{3}{|c|}{$\begin{array}{c}\text { p-values with Tukey-Kramer adjustment showing } \\
\text { the effect of AGE }\end{array}$} \\
\hline & & & 1 & 5 & 6 & Year $1 \& 5$ & Year $1 \& 6$ & Year $5 \& 6$ \\
\hline American Crabapple & Age & 0.0153 & 0.18 & 0.94 & 1.22 & 0.04 & 0.01 & 0.24 \\
\hline Black Cherry & Age & 0.0005 & 0.38 & 2.10 & 2.20 & 0.0004 & 0.0005 & 0.79 \\
\hline Black Chokeberry & Age & $<.0001$ & 0.43 & 0.95 & 1.05 & $<.0001$ & $<.0001$ & 0.0004 \\
\hline Blueberry & Age & 0.0033 & 0.12 & 0.54 & 0.65 & 0.005 & 0.003 & 0.08 \\
\hline Chokecherry & Age & $<.0001$ & 0.28 & 1.63 & 1.78 & $<.0001$ & $<.0001$ & 0.15 \\
\hline Common Apple & Age & 0.0017 & 0.58 & 1.36 & 1.42 & 0.002 & 0.002 & 0.79 \\
\hline Common Pear & Age & 0.0003 & 0.42 & 2.08 & 2.16 & 0.0003 & 0.0003 & 0.82 \\
\hline Eastern Redbud & Age & 0.0006 & 0.30 & 1.21 & 1.34 & 0.0007 & 0.0005 & 0.25 \\
\hline Elderberry & Age & $<.0001$ & 0.04 & 0.98 & 1.15 & $<.0001$ & $<.0001$ & 0.08 \\
\hline Flowering Dogwood & Age & 0.0003 & 0.15 & 1.07 & 1.14 & 0.0003 & 0.0002 & 0.62 \\
\hline Gray Dogwood & Age & 0.0063 & 0.38 & 1.94 & 2.04 & 0.006 & 0.006 & 0.86 \\
\hline Hazelnut & Age & 0.0004 & 0.35 & 0.85 & 0.90 & 0.0004 & 0.0003 & 0.48 \\
\hline Highbush Cranberry & Age & 0.0003 & 0.23 & 1.92 & 2.00 & 0.0003 & 0.0004 & 0.84 \\
\hline Nannyberry & Age & $<.0001$ & 0.30 & 1.33 & 1.43 & $<.0001$ & $<.0001$ & 0.19 \\
\hline Pawpaw & Age & $<.0001$ & 0.13 & 0.68 & 0.78 & 0.0002 & $<.0001$ & 0.14 \\
\hline Persimmon & Age & 0.0184 & 0.25 & 1.16 & 1.23 & 0.02 & 0.02 & 0.87 \\
\hline Red Mulberry & Age & 0.0017 & 0.32 & 1.90 & 1.73 & 0.002 & 0.003 & 0.75 \\
\hline Serviceberry & Age & $<.0001$ & 0.20 & 1.64 & 1.74 & $<.0001$ & $<.0001$ & 0.55 \\
\hline Washington Hawthorn & Age & 0.0003 & 0.63 & 1.54 & 1.60 & 0.0003 & 0.0003 & 0.73 \\
\hline Wild Plum & Age & $<.0001$ & 0.37 & 1.62 & 1.72 & $<.0001$ & $<.0001$ & 0.43 \\
\hline
\end{tabular}


Table 6A. ANOVA results testing the effect of aspect on species height and the effect of the interaction of aspect*age on the sites planted in 2010, Fola and ICG with age used as a repeated measure. The Tukey-Kramer adjustment was made to the calculated pvalues in order to make the test more conservative and control type I errors from occurring.

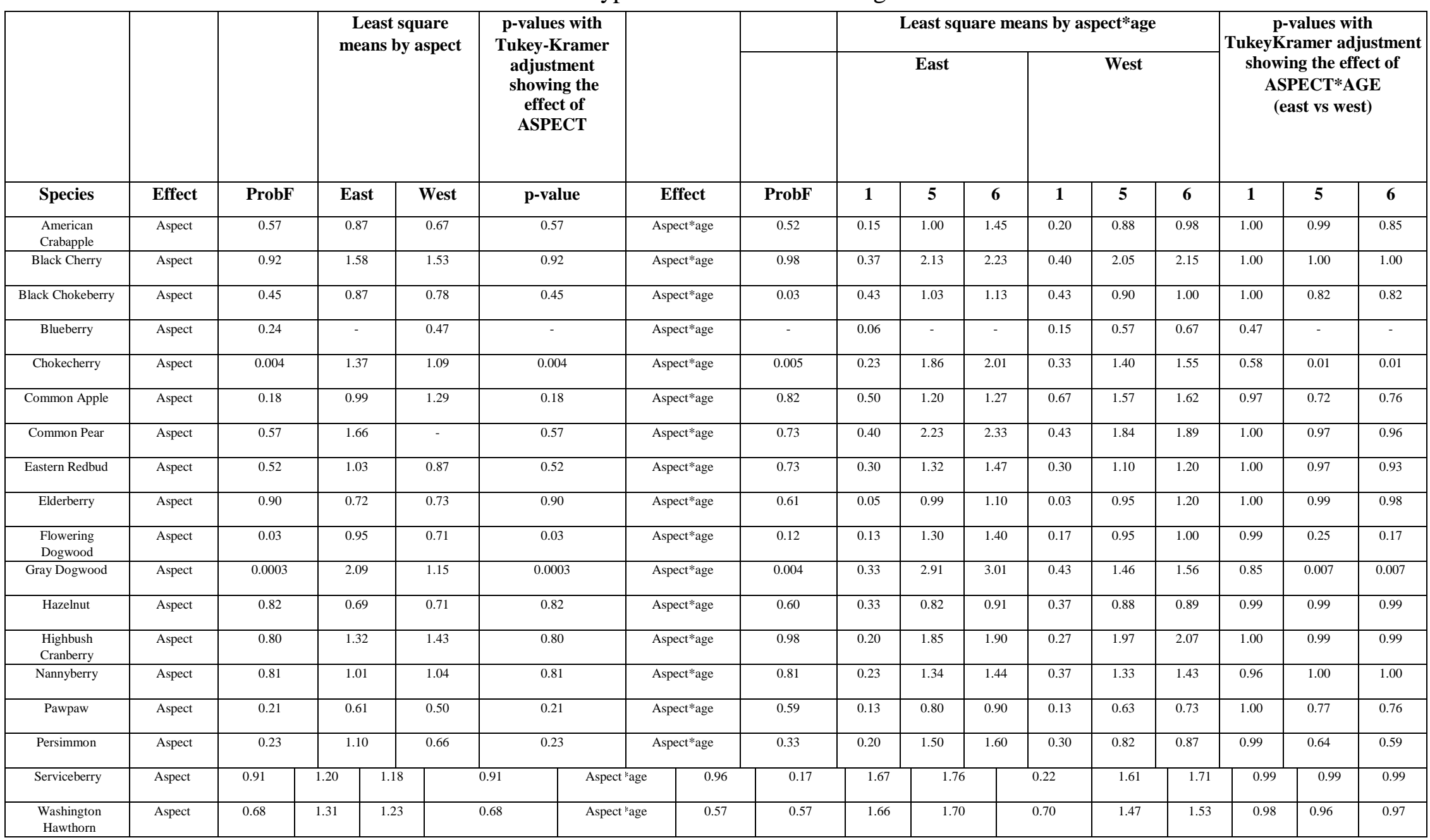




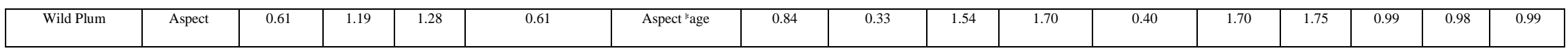

Table 7A. ANOVA results testing the effect of site and aspect, their interaction on species height in 2016 only on the sites planted in 2010, Fola and ICG with age used as a repeated measure. The Tukey-Kramer adjustment was made to the calculated p-values in order to make the test more conservative and control type I errors from occurring.

\begin{tabular}{|c|c|c|c|c|c|c|c|c|c|c|c|c|c|c|c|c|c|c|}
\hline \multirow[b]{3}{*}{ Species } & \multirow[b]{3}{*}{ Effect } & \multirow[b]{3}{*}{ ProbF } & \multirow{2}{*}{\multicolumn{2}{|c|}{$\begin{array}{l}\text { Least square } \\
\text { means by site }\end{array}$}} & \multirow{3}{*}{$\begin{array}{c}\text { p-values } \\
\text { with Tukey- } \\
\text { Kramer } \\
\text { adjustment } \\
\text { showing the } \\
\text { effect of } \\
\text { SITE } \\
\\
\text { p-value }\end{array}$} & \multirow[b]{3}{*}{ Effect } & \multirow[b]{3}{*}{ ProbF } & \multirow{2}{*}{\multicolumn{2}{|c|}{$\begin{array}{c}\text { Least square } \\
\text { means by } \\
\text { aspect }\end{array}$}} & \multirow{3}{*}{$\begin{array}{c}\text { p-values } \\
\text { with Tukey- } \\
\text { Kramer } \\
\text { adjustment } \\
\text { showing the } \\
\text { effect of } \\
\text { ASPECT } \\
\\
\text { p-value }\end{array}$} & \multirow[b]{3}{*}{ Effect } & \multirow[b]{3}{*}{ ProbF } & \multicolumn{4}{|c|}{$\begin{array}{c}\text { Least square means by } \\
\text { site*aspect }\end{array}$} & \multicolumn{2}{|c|}{$\begin{array}{c}\text { p-values with } \\
\text { Tukey-Kramer } \\
\text { adjustment } \\
\text { showing the } \\
\text { effect of } \\
\text { SITE*ASPECT }\end{array}$} \\
\hline & & & & & & & & & & & & & \multicolumn{2}{|c|}{ Fola } & \multicolumn{2}{|c|}{ ICG } & & \\
\hline & & & Fola & ICG & & & & East & West & & & & East & West & East & West & East & West \\
\hline $\begin{array}{l}\text { American } \\
\text { Crabapple }\end{array}$ & Site & 0.80 & 0.74 & 0.61 & 0.80 & Aspect & 0.72 & 0.77 & 0.58 & 0.82 & Site*aspect & 0.43 & 0.57 & 0.91 & 0.97 & 0.24 & 0.90 & 0.75 \\
\hline Black Cherry & Site & 0.99 & 1.20 & 1.19 & 0.99 & Aspect & 0.82 & 1.32 & 1.07 & 0.82 & Site*aspect & 0.93 & 1.28 & 1.12 & 1.36 & 1.02 & 0.99 & 0.99 \\
\hline $\begin{array}{l}\text { Black } \\
\text { Chokeberry }\end{array}$ & Site & 0.45 & 0.88 & 0.61 & 0.45 & Aspect & 0.91 & 0.73 & 0.76 & 0.91 & Site*aspect & 0.97 & 0.86 & 0.90 & 0.60 & 0.63 & 0.92 & 0.88 \\
\hline Blueberry & Site & 0.71 & 0.07 & 0.19 & 0.71 & Aspect & 0.64 & 0.06 & 0.20 & 0.64 & Site*aspect & 0.59 & 0.09 & 0.06 & 0.03 & 0.35 & 0.99 & 0.91 \\
\hline Chokecherry & Site & 0.66 & 1.07 & 0.72 & 0.66 & Aspect & 0.88 & 0.95 & 0.83 & 0.88 & Site*aspect & 0.98 & 1.12 & 1.02 & 0.78 & 0.65 & 0.98 & 0.98 \\
\hline $\begin{array}{l}\text { Common } \\
\text { Apple }\end{array}$ & Site & 0.45 & 1.18 & 0.85 & 0.45 & Aspect & 0.71 & 0.94 & 1.09 & 0.71 & Site*aspect & 0.86 & 1.07 & 1.29 & 0.81 & 0.89 & 0.94 & 0.86 \\
\hline Common Pear & Site & 0.52 & 1.63 & 0.98 & 0.52 & Aspect & 0.62 & 1.54 & 1.06 & 0.62 & Site*aspect & 0.85 & 1.96 & 1.29 & 1.13 & 0.82 & 0.88 & 0.98 \\
\hline $\begin{array}{l}\text { Eastern } \\
\text { Redbud } \\
\end{array}$ & Site & 0.36 & 1.04 & 0.48 & 0.36 & Aspect & 0.90 & 0.80 & 0.73 & 0.90 & Site*aspect & 0.81 & 1.01 & 1.07 & 0.58 & 0.39 & 0.90 & 0.75 \\
\hline Elderberry & Site & 0.76 & 0.56 & 0.39 & 0.76 & Aspect & 0.94 & 0.45 & 0.50 & 0.94 & Site*aspect & 0.88 & 0.50 & 0.63 & 0.41 & 0.36 & 0.99 & 0.98 \\
\hline $\begin{array}{l}\text { Flowering } \\
\text { Dogwood }\end{array}$ & Site & 0.94 & 0.42 & 0.45 & 0.94 & Aspect & 0.75 & 0.35 & 0.52 & 0.75 & Site*aspect & 0.64 & 0.20 & 0.63 & 0.50 & 0.51 & 0.98 & 0.98 \\
\hline $\begin{array}{l}\text { Gray } \\
\text { Dogwood }\end{array}$ & Site & 0.76 & 0.66 & 0.98 & 0.76 & Aspect & 0.91 & 0.76 & 0.87 & 0.71 & Site*aspect & 0.70 & 0.40 & 0.91 & 1.12 & 0.83 & 0.95 & 0.99 \\
\hline Hazelnut & Site & 0.41 & 0.71 & 0.47 & 0.41 & Aspect & 0.88 & 0.57 & 0.61 & 0.88 & Site*aspect & 0.78 & 0.66 & 0.77 & 0.49 & 0.45 & 0.95 & 0.78 \\
\hline $\begin{array}{l}\text { Highbush } \\
\text { Cranberry }\end{array}$ & Site & 0.83 & 0.87 & 1.09 & 0.83 & Aspect & 0.83 & 0.88 & 1.09 & 0.93 & Site*aspect & 0.67 & 0.98 & 0.77 & 0.77 & 1.42 & 0.99 & 0.94 \\
\hline Nannyberry & Site & 0.62 & 0.99 & 0.70 & 0.62 & Aspect & 0.71 & 0.74 & 0.95 & 0.71 & Site*aspect & 0.91 & 0.92 & 1.07 & 0.56 & 0.84 & 0.95 & 0.98 \\
\hline Pawpaw & Site & 0.58 & 0.24 & 0.42 & 0.58 & Aspect & 0.58 & 0.24 & 0.42 & 0.58 & Site*aspect & 0.75 & 0.10 & 0.38 & 0.48 & 0.46 & 0.92 & 0.99 \\
\hline Persimmon & Site & 0.93 & 0.58 & 0.64 & 0.93 & Aspect & 0.83 & 0.59 & 0.53 & 0.83 & Site*aspect & 0.77 & 0.55 & 0.61 & 0.82 & 0.46 & 0.99 & 0.99 \\
\hline Red Mulberry & Site & 0.76 & 1.07 & 0.85 & 0.76 & Aspect & 0.96 & 0.98 & 0.95 & 0.96 & Site*aspect & 0.77 & 0.99 & 1.16 & 0.94 & 0.73 & 1.00 & 0.96 \\
\hline Serviceberry & Site & 0.63 & 0.19 & 0.26 & 0.63 & Aspect & 0.96 & 0.82 & 0.86 & 0.96 & Site*aspect & 0.86 & 0.75 & 1.12 & 0.70 & 0.60 & 0.99 & 0.94 \\
\hline
\end{tabular}




\begin{tabular}{|l|c|c|c|c|c|c|c|c|c|c|c|c|c|c|c|c|c|c|c|}
\hline $\begin{array}{l}\text { Washington } \\
\text { Hawthorn }\end{array}$ & Site & 0.56 & 1.27 & 0.96 & 0.56 & Aspect & 0.77 & 1.04 & 1.19 & 0.77 & Site*aspect & 0.93 & 1.17 & 1.37 & 0.91 & 1.01 & 0.97 & 0.93 \\
\hline Wild Plum & Site & 0.57 & 1.15 & 0.73 & 0.57 & Aspect & 0.87 & 0.88 & 0.99 & 0.87 & Site*aspect & 0.83 & 1.01 & 1.28 & 0.75 & 0.71 & 0.99 & 0.90 \\
\hline
\end{tabular}

Table 8A. ANOVA results testing the effect of site and aspect, their interaction on growth form height in 2016 only on the sites planted in 2010, Fola and ICG with age used as a repeated measure. The Tukey-Kramer adjustment was made to the calculated pvalues in order to make the test more conservative and control type I errors from occurring.

\begin{tabular}{|l|c|c|c|}
\hline Effect & Pr $>$ F & \multicolumn{2}{|c|}{ Least square means } \\
\hline Growth form & 0.0532 & Shrub & Tree \\
\hline $\begin{array}{l}\text { Species within growth } \\
\text { form }\end{array}$ & $<0.0001$ & 1.23 & 1.46 \\
\cline { 1 - 2 } Site & 0.68 & & \\
\hline
\end{tabular}

Results of PCA 


\section{Summary Plots}

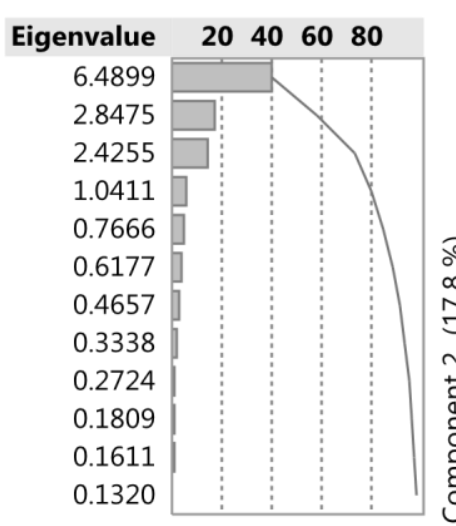

Eigenvalues
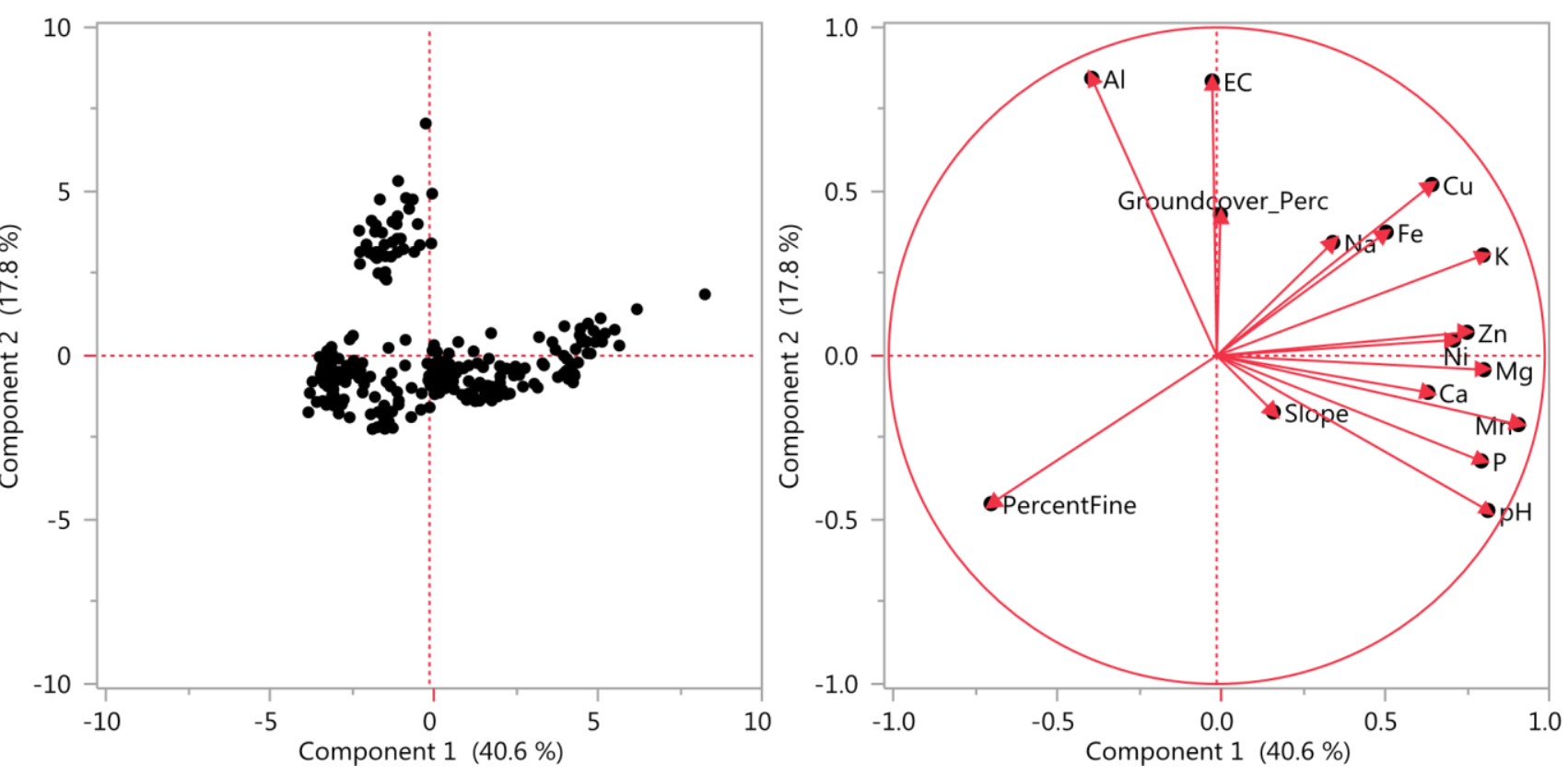

$\checkmark$ Label variables 


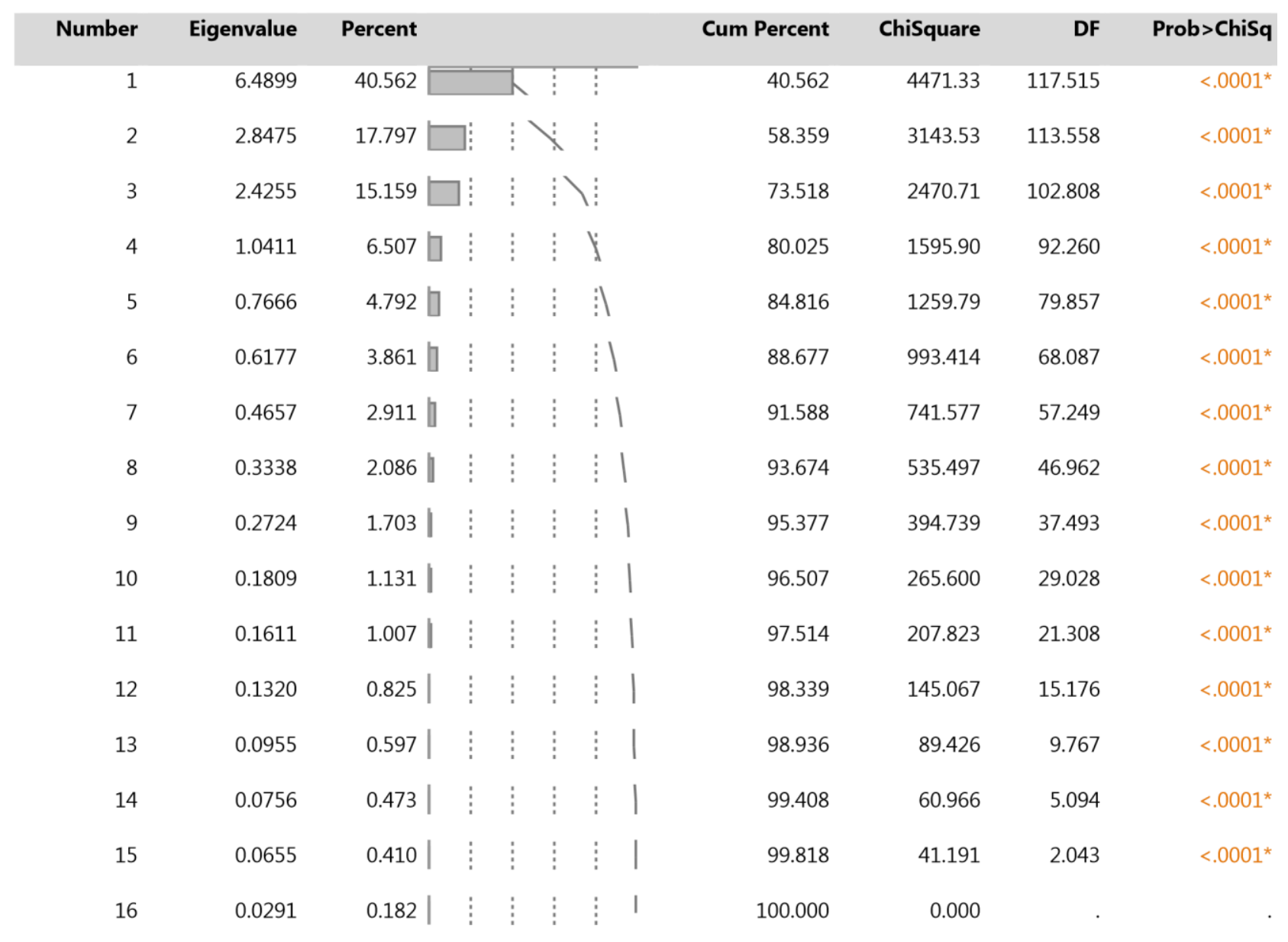




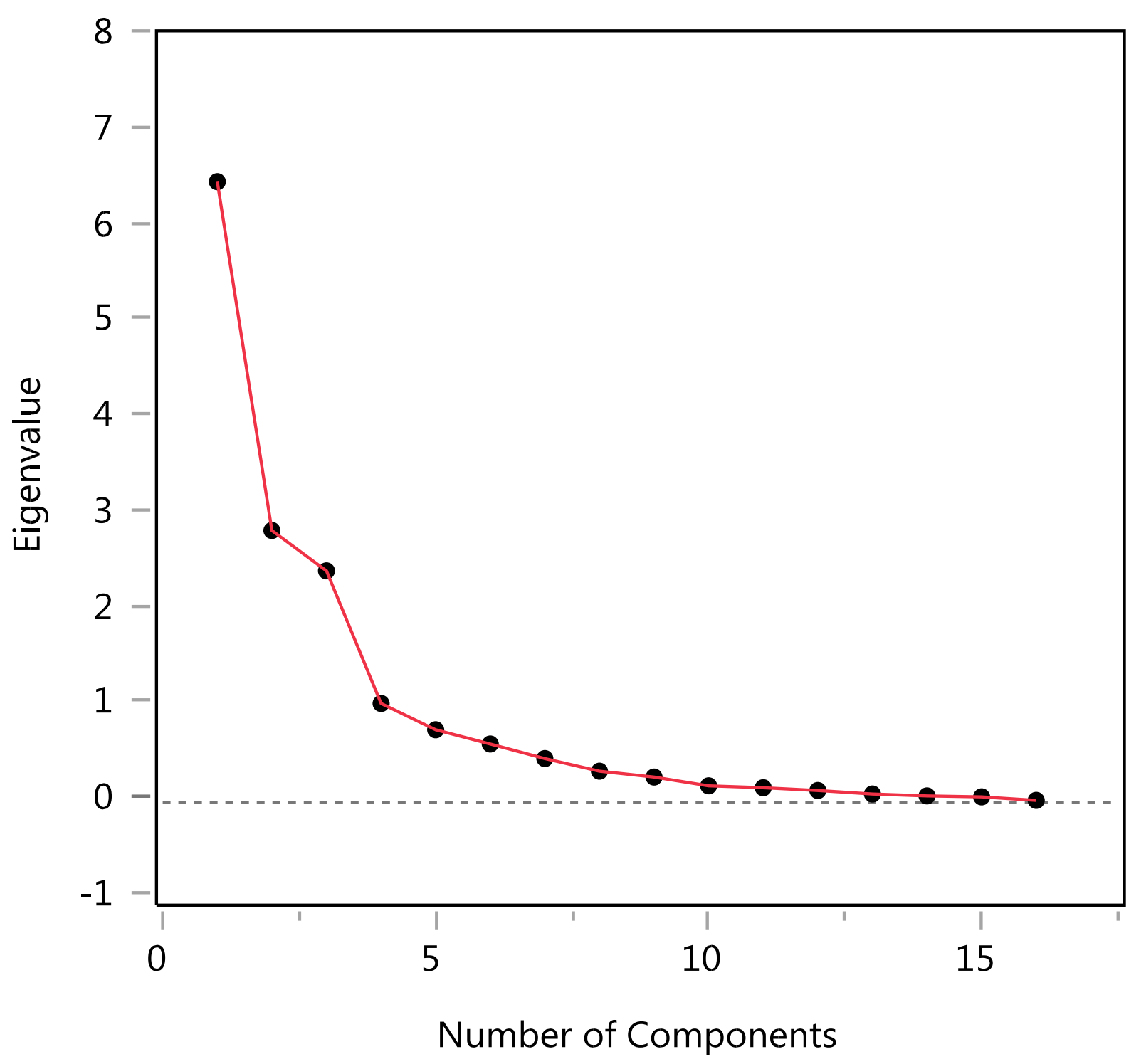




\begin{tabular}{|c|c|c|c|c|c|c|c|c|c|c|c|c|c|c|c|c|}
\hline & Prin & Prin2 & Prin3 & Prin4 & Prin5 & Prin6 & Prin7 & Prin8 & Prin9 & Prin10 & Prin11 & Prin12 & Prin13 & Prin14 & Prin15 & Prin16 \\
\hline Slope & 0.06766 & $\begin{array}{lll}-0.10154 & -0.2\end{array}$ & .23144 & 0.71235 & 0.58898 & 0.00623 & 0.00839 & 0.17751 & -0.08518 & 0.10333 & 0.04951 & 0.050 & $042-0.0754$ & $54-0.03866$ & -0.11079 & -0.05661 \\
\hline PercentFine & -0.27003 & $3-0.26704$ & 0.14012 & 0.00953 & -0.10520 & 0.10896 & 0.39051 & 0.56684 & 0.50337 & 0.17524 & 0.10324 & $4-0.20114$ & 0.01586 & 0.03353 & -0.04824 & -0.02002 \\
\hline $\mathrm{pH}$ & 0.32447 & -0.27931 & 0.00859 & $-0.09110-$ & -0.00311 & 0.02658 & 0.16382 & 0.04950 & -0.04002 & 0.02623 & 0.00165 & 0.47850 & 0.03610 & $0.73068-c$ & -0.10034 & 0.04240 \\
\hline EC & -0.00542 & $2 \quad 0.49576$ & 0.10711 & -0.05427 & 0.26832 & -0.05454 & 0.57619 & -0.03885 & 0.05311 & -0.53515 & 0.11796 & 0.00587 & -0.11525 & 0.08642 & -0.01902 & -0.08382 \\
\hline K & 0.31870 & 0.18161 & -0.23296 & $-0.05314-c$ & -0.06230 & 0.09206 & 0.05394 & -0.20112 & 0.11865 & 0.22635 & 0.47438 & $8-0.32336$ & 0.29829 & $0.04409-C$ & -0.51605 & 0.02237 \\
\hline $\mathrm{Ca}$ & 0.25276 & -0.06610 & 0.42468 & 0.23023 & -0.11537 & $-0.17277-$ & -0.11278 & 0.10201 & 0.10364 & -0.26189 & 0.20027 & 0.15298 & 0.05572 & $-0.23109-0$ & 0.11326 & 0.64802 \\
\hline $\mathrm{Mg}$ & 0.31970 & -0.02529 & 0.30996 & 0.13935 & -0.14104 & -0.06921 & $-0.13120-$ & -0.02604 & 0.24601 & -0.02832 & 0.25973 & 0.26817 & 0.00855 & -0.21198 & 0.10698 & -0.69421 \\
\hline $\mathrm{Na}$ & 0.13881 & 0.20438 & 0.33504 & -0.11518 & 0.19575 & 0.79314 & -0.21617 & 0.25572 & $2-0.16780$ & -0.00217 & -0.04142 & -0.03616 & 0.04964 & $0.01186-c$ & -0.01129 & 0.00178 \\
\hline$P$ & 0.31650 & $-0.19000-0.0$ & .00421 & 0.00224 & -0.01784 & 0.21062 & 0.55643 & $3-0.25755$ & -0.02581 & 0.19900 & -0.40191 & 0.13497 & 0.17704 & -0.43295 & 0.02382 & 0.06094 \\
\hline Al & -0.14958 & $8 \quad 0.50064$ & 0.10019 & 0.07968 & 0.06760 & -0.20318 & 0.00429 & 0.12690 & 0.05514 & 0.38674 & -0.06217 & 0.26615 & 0.58987 & 0.07980 & 0.24654 & 0.07876 \\
\hline $\mathrm{Fe}$ & 0.20277 & 0.22295 & 0.42665 & 0.09643 & $-0.05173-$ & -0.30545 & 0.00929 & 0.05979 & -0.08953 & 0.30397 & -0.43018 & $8-0.30627$ & -0.30665 & 0.16852 & -0.32727 & -0.09697 \\
\hline $\mathrm{Mn}$ & 0.36091 & -0.12435 & 0.07303 & 0.11437 & 0.01997 & -0.05695 & 0.08524 & $4-0.03302$ & -0.09855 & -0.01459 & 0.12584 & $4-0.54359$ & 0.11807 & 0.22361 & 0.66037 & 0.05076 \\
\hline $\mathrm{Cu}$ & 0.25739 & 0.30900 & -0.26552 & -0.08902 & 0.03239 & 0.09762 & -0.07197 & -0.02128 & 0.45312 & 0.29043 & 0.03649 & 0.16100 & $0-0.54570$ & -0.03121 & 0.26745 & 0.23753 \\
\hline $\mathrm{Ni}$ & 0.28347 & 0.02828 & -0.21604 & -0.35773 & 0.01750 & -0.26399 & 0.08460 & 0.59319 & -0.44520 & 0.06776 & 0.15591 & 0.07439 & $9-0.06811-$ & -0.27563 & 0.00711 & -0.04328 \\
\hline Zn & 0.29954 & 0.04228 & -0.31150 & -0.04521 & 0.03304 & -0.06460 & -0.25372 & 0.24310 & 0.38805 & -0.40945 & -0.49456 & -0.12226 & 0.30081 & 0.01820 & -0.08749 & -0.06658 \\
\hline $\begin{array}{l}\text { Groundcover_Per } \\
\text { c }\end{array}$ & 0.00434 & $0.25463-$ & -0.24630 & 0.47543 & -0.69586 & 0.21596 & 0.12380 & 0.16666 & $5-0.21425$ & $-0.11198-$ & -0.04619 & 0.04540 & -0.06841 & 0.07816 & 0.02184 & -0.02407 \\
\hline
\end{tabular}

Normalization of tree height

\section{Distributions}

Normalized_Height 


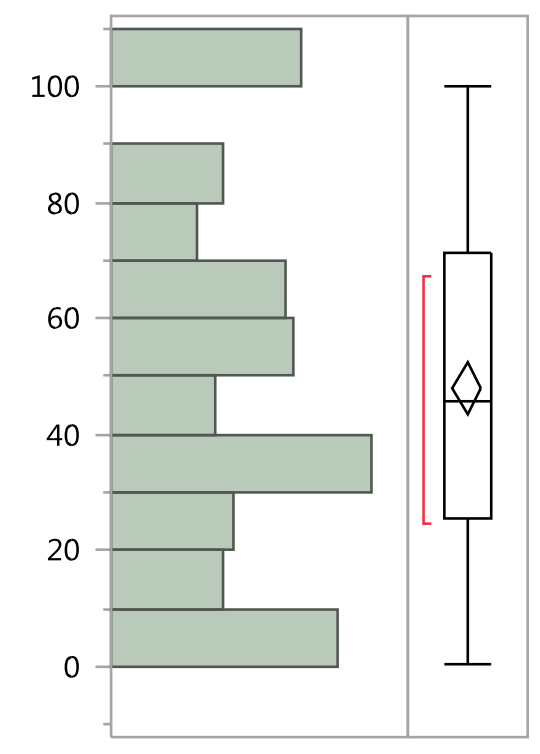

\section{Quantiles}

$\begin{array}{lrr}100.0 \% & \text { maximum } & 100 \\ 99.5 \% & 100 \\ 97.5 \% & 100 \\ 90.0 \% & & 100 \\ 75.0 \% & \text { quartile } & 71.160815988 \\ 50.0 \% & \text { median } & 45.945945946 \\ 25.0 \% & \text { quartile } & 25.465838509 \\ 10.0 \% & & 1.7036322726 \\ 2.5 \% & & 0.6211180124\end{array}$




\section{Summary Statistics}

\begin{tabular}{lr} 
Mean & 48.092129 \\
Std Dev & 30.871267 \\
Std Err Mean & 2.2946432 \\
Upper 95\% Mean & 52.619989 \\
Lower 95\% Mean & 43.564268 \\
\hline & \\
\hline
\end{tabular}

PC Regression; Response Normalized_Height

\section{Whole Model}

\section{Effect Summary}

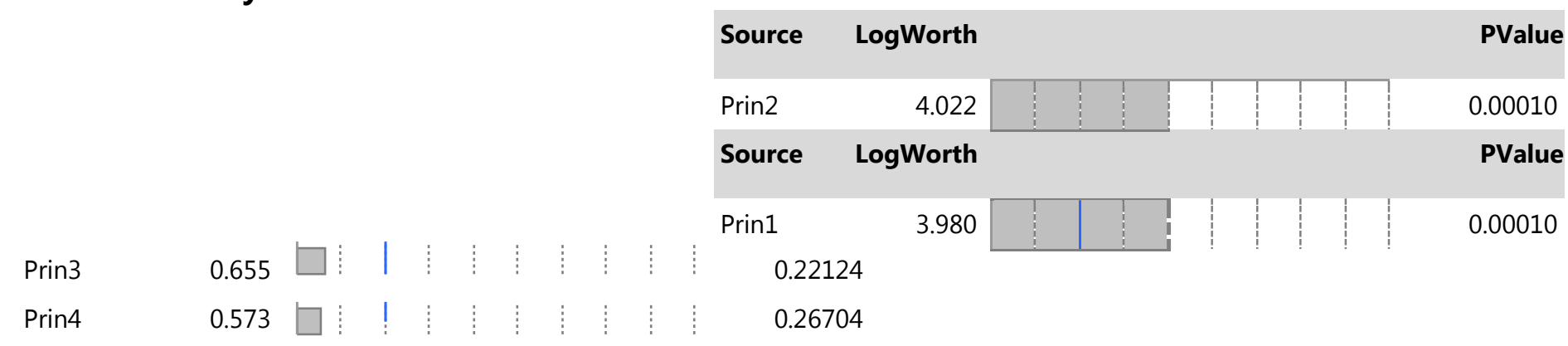




\section{Actual by Predicted Plot}

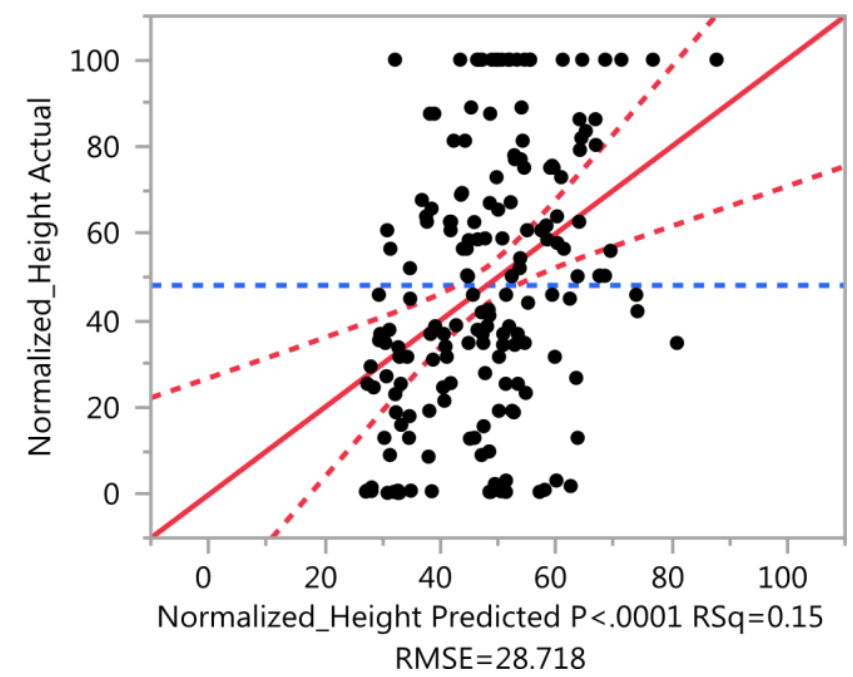

\section{Summary of Fit}

RSquare

0.153841

RSquare Adj

0.13461

Root Mean Square Error

Mean of Response

48.09213

Observations (or Sum Wgts)

\section{Analysis of Variance}

\begin{tabular}{lrrrr} 
Source & DF & $\begin{array}{r}\text { Sum of } \\
\text { Squares }\end{array}$ & Mean Square & F Ratio \\
\hline Model & 4 & 26390.86 & 6597.72 & 7.9997
\end{tabular}




\begin{tabular}{lllll|} 
Error & 176 & 145155.46 & 824.75 & Prob > F \\
\hline C. Total & 180 & 171546.33 & & $<.0001^{*}$
\end{tabular}

\section{Parameter Estimates}

$\begin{array}{lrrrrr}\text { Term } & \text { Estimate } & \text { Std Error } & \text { t Ratio } & \text { Prob }>|\mathbf{t}| & \text { VIF } \\ \text { Intercept } & 46.046001 & 2.189009 & 21.04 & <.0001^{*} & . \\ \text { Prin1 } & 3.1479698 & 0.793056 & 3.97 & 0.0001^{*} & 1.0184545 \\ \text { Prin2 } & 4.7166436 & 1.180701 & 3.99 & <.0001^{*} & 1.0049939 \\ \text { Prin3 } & -1.45801 & 1.187708 & -1.23 & 0.2212 & 1.0019967 \\ \text { Prin4 } & -2.25508 & 2.025331 & -1.11 & 0.2670 & 1.0149164\end{array}$

Multiple Linear regression on the variables selected based on PCR

Response Normalized_Height

Whole Model

Effect Summary 


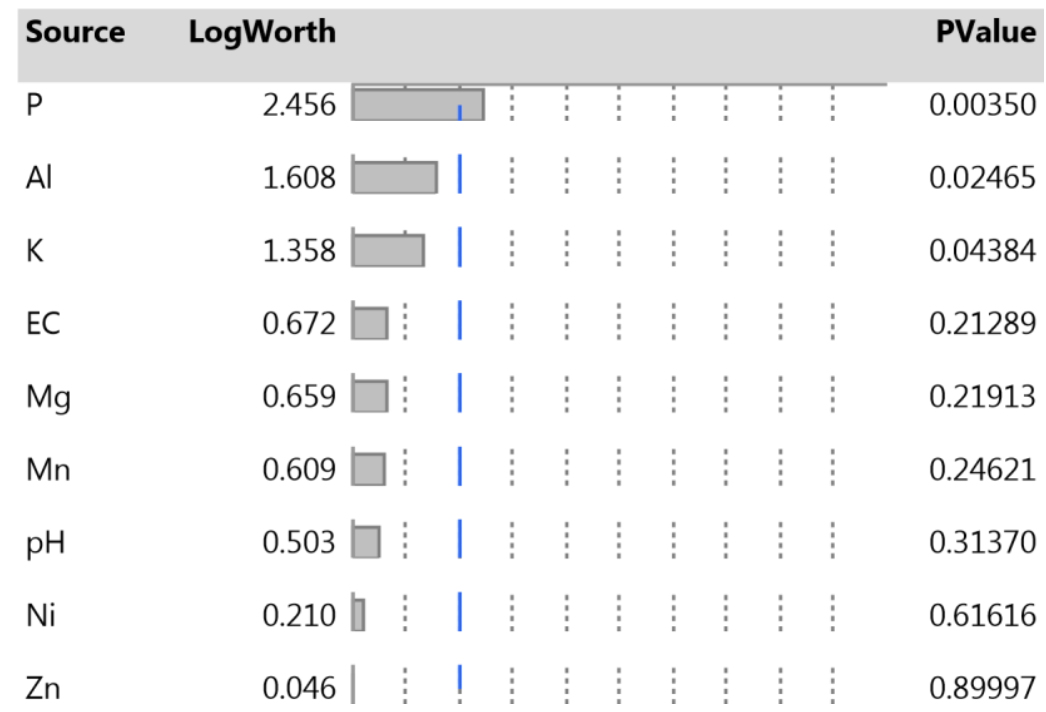

\section{Actual by Predicted Plot}




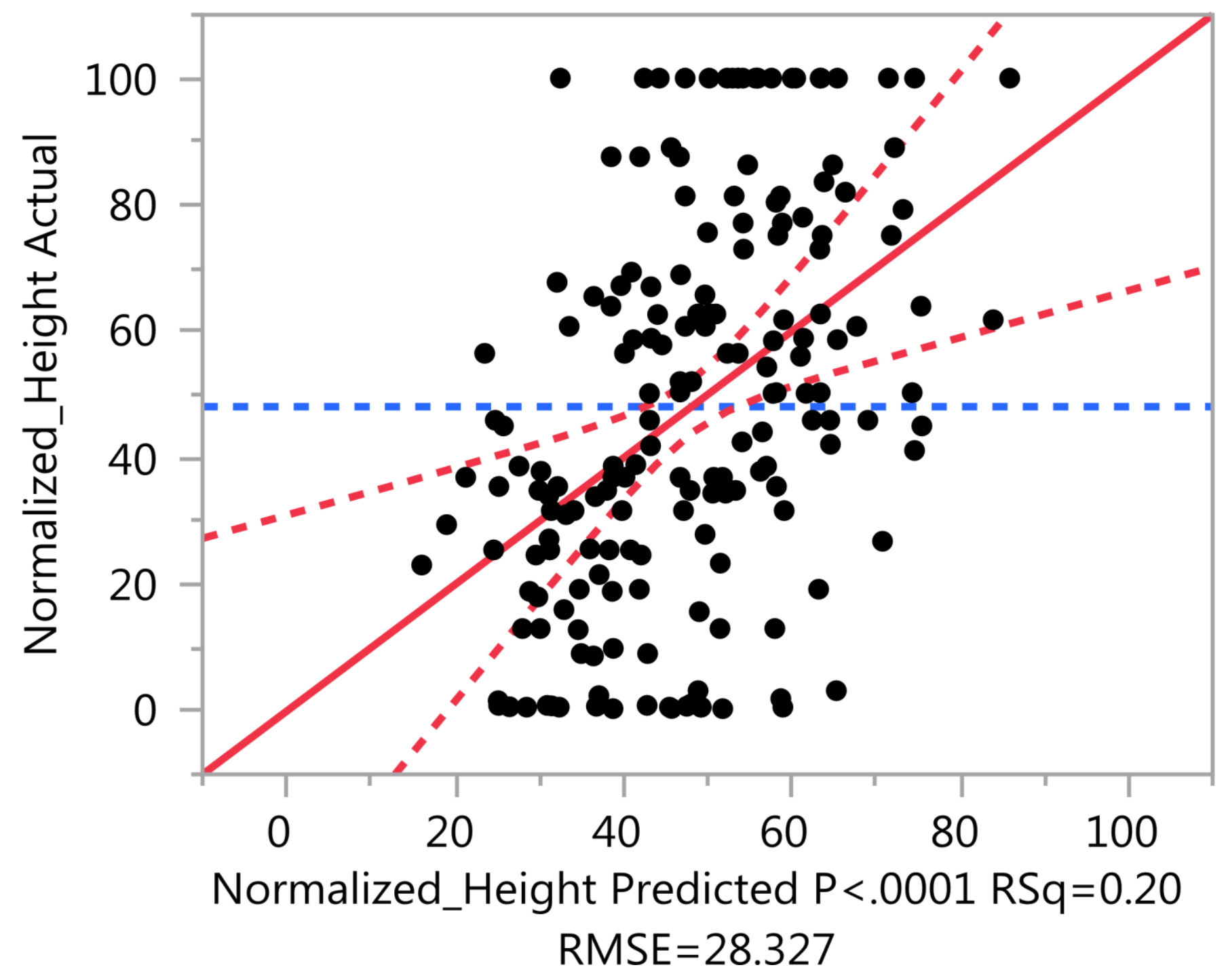

Summary of Fit 


$\begin{array}{lr}\text { RSquare } & 0.200158 \\ \text { RSquare Adj } & 0.158061 \\ \text { Root Mean Square Error } & 28.32662 \\ \text { Mean of Response } & 48.09213 \\ \text { Observations (or Sum Wgts) } & 181\end{array}$

\section{Analysis of Variance}

\begin{tabular}{lrrrrr} 
Source & DF & $\begin{array}{r}\text { Sum of } \\
\text { Squares }\end{array}$ & Mean Square & F Ratio \\
\hline Model & 9 & 34336.40 & 3815.16 & 4.7547 \\
\hline Error & 171 & 137209.93 & 802.40 & Prob > F \\
\hline C. Total & 180 & 171546.33 & & $<.0001^{*}$
\end{tabular}

\section{Parameter Estimates}

\section{Parameter Estimates}

$\begin{array}{lrrrrr}\text { Term } & \text { Estimate } & \text { Std Error } & \text { t Ratio } & \text { Prob }>|\mathbf{t}| & \text { VIF } \\ \text { Intercept } & 29.657375 & 20.82034 & 1.42 & 0.1561 & . \\ \mathrm{pH} & -4.483019 & 4.436551 & -1.01 & 0.3137 & 13.487602 \\ \mathrm{EC} & -0.05522 & 0.044164 & -1.25 & 0.2129 & 3.0359087 \\ \mathrm{~K} & 149.76198 & 73.75245 & 2.03 & 0.0438^{*} & 3.8673895 \\ \text { Term } & \text { Estimate } & \text { Std Error } & \mathbf{t} \text { Ratio } & \text { Prob }>|\mathbf{t}| & \text { VIF }\end{array}$




$\begin{array}{llllll}\mathrm{Mg} & 3.2032505 & 2.597154 & 1.23 & 0.2191 & 4.0870685 \\ \mathrm{P} & 0.7761465 & 0.262086 & 2.96 & 0.0035^{*} & 5.8902258 \\ \mathrm{Al} & 0.1386682 & 0.061172 & 2.27 & 0.0247^{*} & 5.1060651 \\ \mathrm{Mn} & -0.264432 & 0.227254 & -1.16 & 0.2462 & 7.2975933 \\ \mathrm{Ni} & 3.6858314 & 7.339177 & 0.50 & 0.6162 & 2.8654562 \\ \mathrm{Zn} & 0.2092189 & 1.662014 & 0.13 & 0.9000 & 3.1931132\end{array}$

\section{Residual by Predicted Plot}

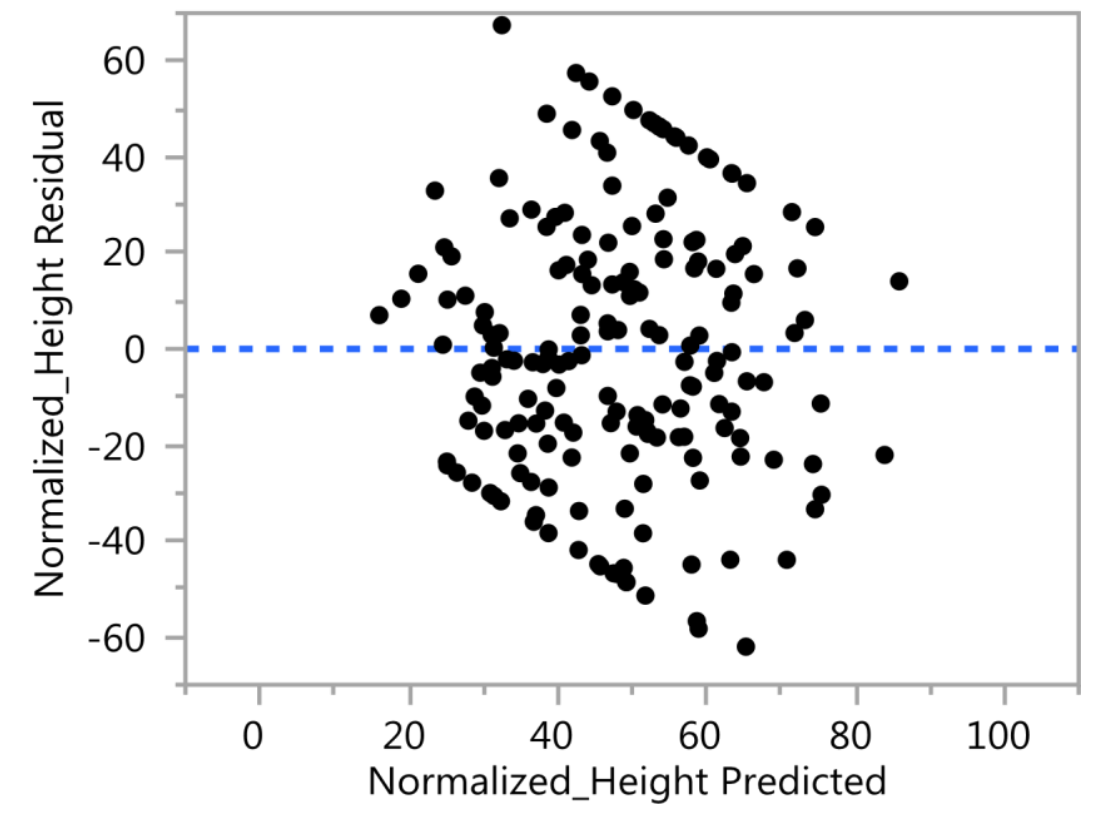




\section{Simpler model}

\section{Effect Summary}

\begin{tabular}{ll|l|} 
K & 2.034 \\
$\mathrm{P}$ & $1.968 \square$ \\
$\mathrm{EC}$ & 0.533 & $\square$ \\
$\mathrm{Mg}$ & 0.020 & $\square$
\end{tabular}

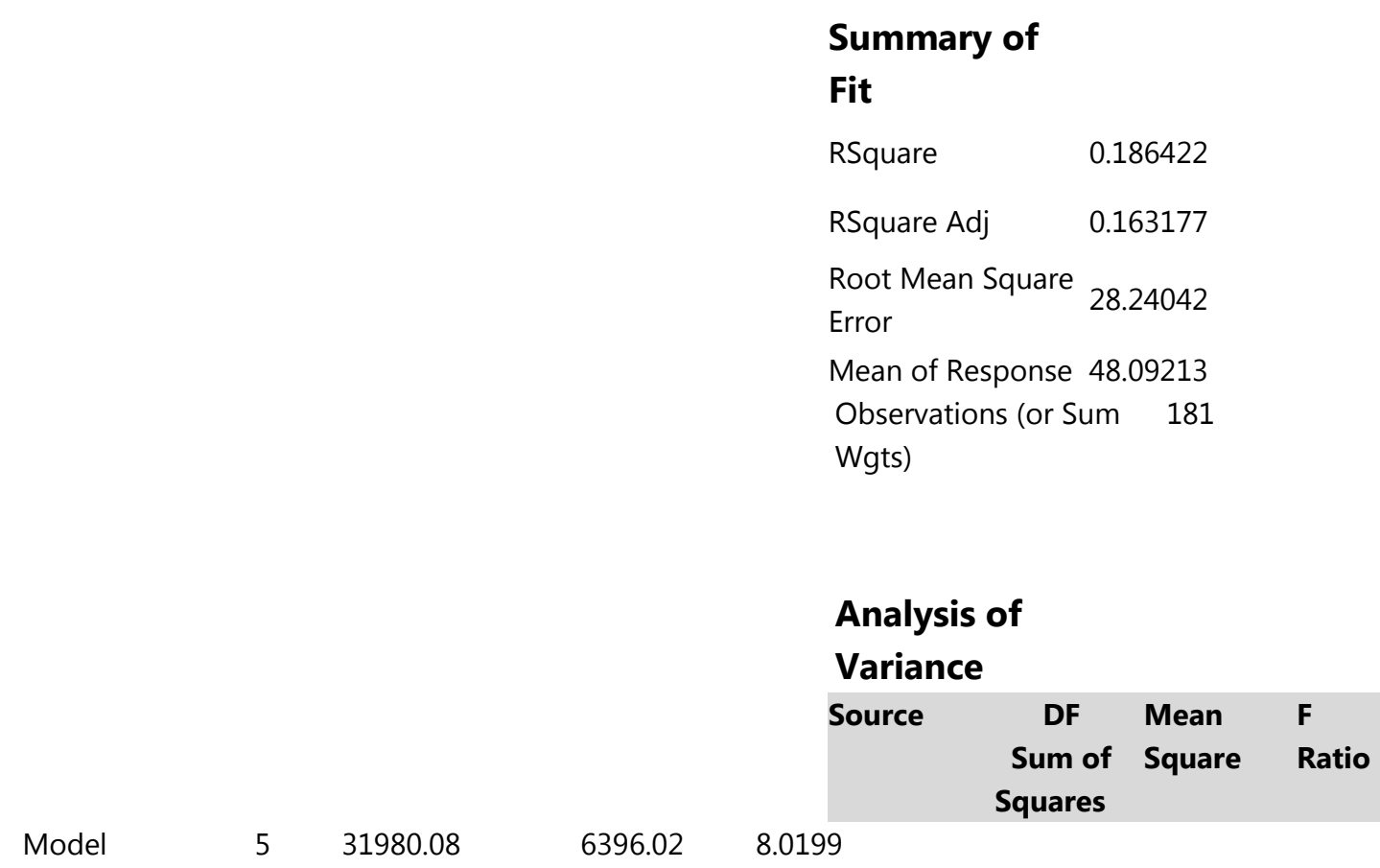

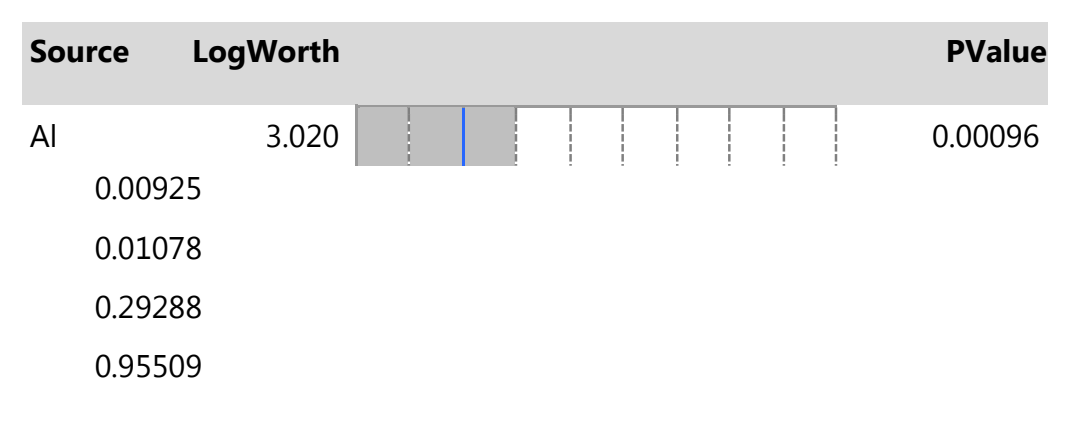




\begin{tabular}{lrrrr} 
Source & DF & $\begin{array}{r}\text { Sum of } \\
\text { Squares }\end{array}$ & Mean Square & F Ratio \\
\hline Error & 175 & 139566.25 & 797.52 & Prob > F \\
\hline C. Total & 180 & 171546.33 & & $<.0001^{*}$
\end{tabular}

\section{Parameter Estimates}

\section{Parameter Estimates}

$\begin{array}{lrrrrr}\text { Term } & \text { Estimate } & \text { Std Error } & \mathbf{t} \text { Ratio } & \text { Prob }>|\mathbf{t}| & \text { VIF } \\ \text { Intercept } & 7.867076 & 6.736194 & 1.17 & 0.2444 & . \\ \text { EC } & -0.043426 & 0.041163 & -1.05 & 0.2929 & 2.6533677 \\ \mathrm{~K} & 128.47438 & 48.81436 & 2.63 & 0.0092 * & 1.70454 \\ \mathrm{Mg} & -0.094004 & 1.666721 & -0.06 & 0.9551 & 1.693516 \\ \mathrm{P} & 0.5322283 & 0.20649 & 2.58 & 0.0108^{*} & 3.6786268 \\ \mathrm{Al} & 0.1826907 & 0.054367 & 3.36 & 0.0010^{*} & 4.0579014\end{array}$

PCA done by individual sites 
Principal Components: on Correlations Site=ELK_RUN

\section{Summary Plots}
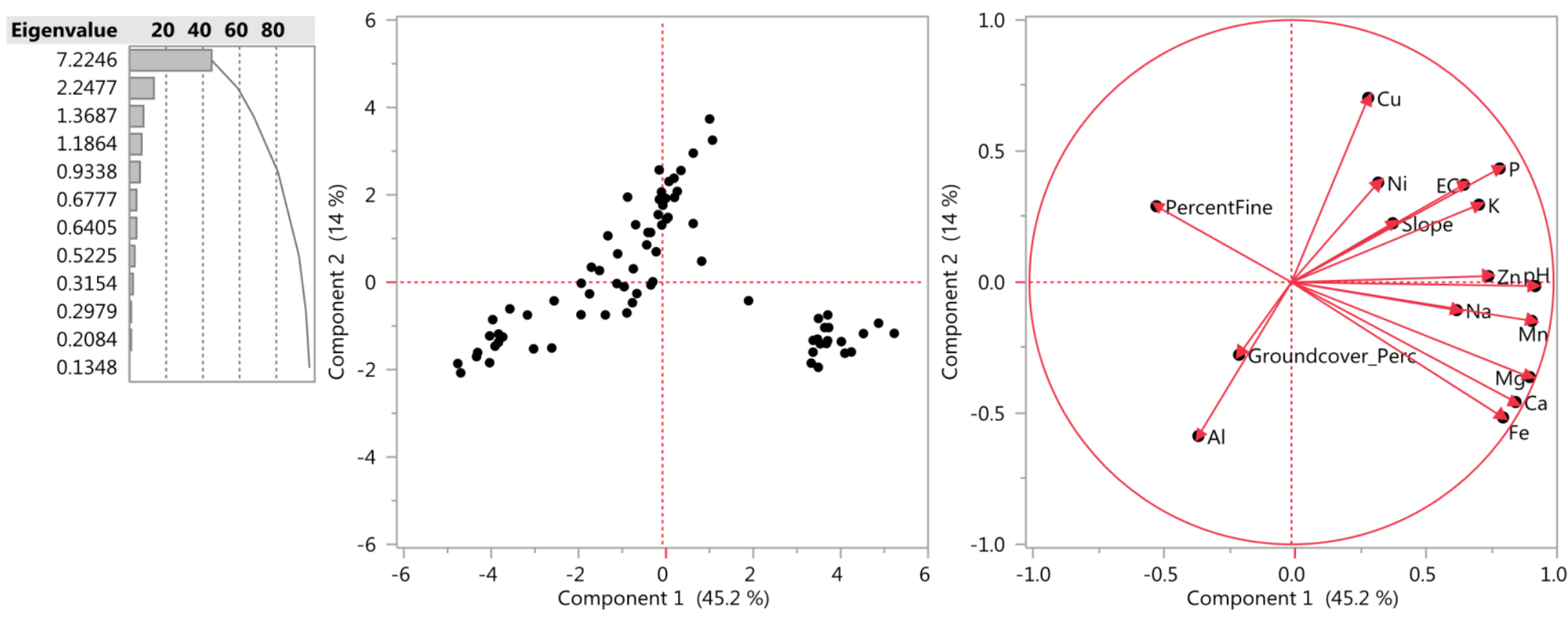

$\checkmark$ Label variables

\section{Eigenvalues}

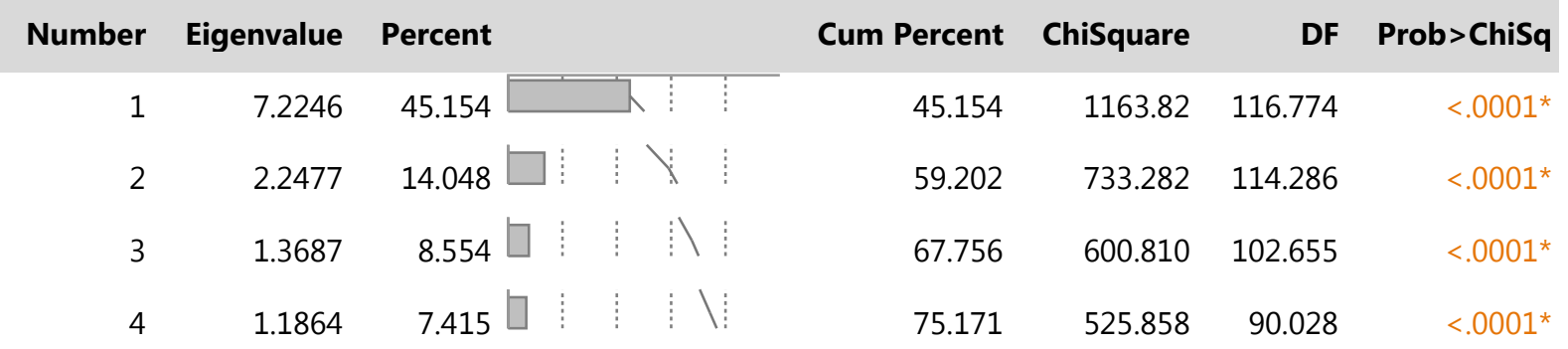




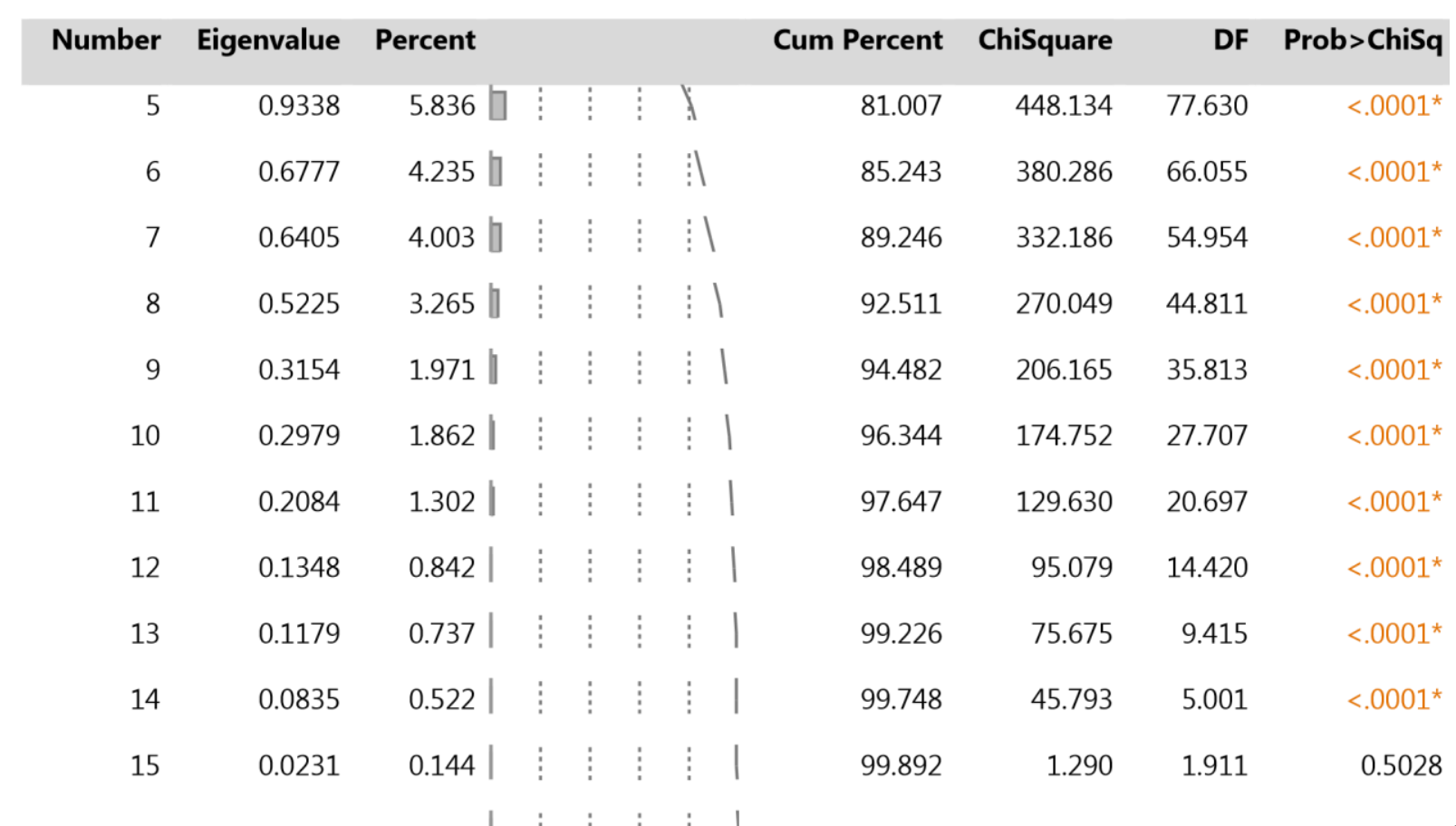
$16 \quad 0.0173 \quad 0.108$
100.000 .

\section{Eigenvectors}

\begin{tabular}{|c|c|c|c|c|c|c|c|c|c|c|c|c|c|c|c|c|}
\hline & Prin1 & Prin2 & Prin3 & Prin4 & Prin5 & Prin6 & Prin7 & Prin8 & Prin9 & Prin10 & Prin11 & Prin12 & Prin13 & Prin14 & Prin15 & Prin16 \\
\hline Slope & 0.14375 & 0.15018 & 0.50710 & 0.12523 & 0.33782 & -0.53515 & 0.34342 & $2-0.13372$ & 0.36105 & $-0.05580-($ & -0.07309 & 0.02552 & 0.07130 & 0.02422 & 0.04141 & 0.02776 \\
\hline PercentFine & -0.19178 & 0.19344 & 0.44594 & 0.03504 & 0.20736 & 0.35799 & -0.46585 & 0.33484 & 0.28586 & -0.01235 & 0.32384 & -0.01516 & 0.18768 & -0.02996 & 0.01155 & 0.04681 \\
\hline $\mathrm{pH}$ & 0.34595 & -0.00980 & 0.0563 & $33-0.18573$ & $3-0.11818$ & -0.02017 & -0.12992 & $-0.03153-0.0$ & 6639 & 0.00373 & 0.14790 & 0.47037 & 0.13903 & 0.49464 & 0.52156 & 0.16351 \\
\hline EC & 0.24467 & 0.24811 & 0.37214 & 0.12664 & 0.14478 & 0.36906 & 0.01975 & 0.02671 & -0.36083 & $-0.00041-0$ & -0.42049 & 0.06565 & -0.50010 & -0.01842 & 0.06273 & -0.00970 \\
\hline K & 0.26606 & 0.19738 & -0.25850 & $-0.19463-0$ & 0.13666 & 0.23974 & -0.09126 & -0.10168 & 0.67827 & $27-0.27936$ & $6-0.36453$ & -0.01241 & $-0.06000-c$ & 0.10558 & 0.03550 & -0.05996 \\
\hline $\mathrm{Ca}$ & 0.31798 & -0.30464 & 0.09501 & 0.04342 & 0.08453 & 0.04991 & -0.04445 & -0.03343 & $0.00942-$ & -0.04933 & 0.19162 & 0.27 & $7042-0.01 s$ & .971-0.27963 & -0.42963 & $3-0.63790$ \\
\hline
\end{tabular}




\begin{tabular}{|c|c|c|c|c|c|c|c|c|c|c|c|c|c|c|c|c|}
\hline & Prin & Prin2 & Prin3 & Prin4 & Prin5 & Prin6 & Prin7 & Prin8 & Prin9 & Prin10 & Prin11 & Prin12 & Prin13 & Prin14 & Prin15 & Prin16 \\
\hline $\mathrm{Mg}$ & 0.33804 & -0.24120 & 0.01212 & 0.00059 & 0.01495 & 0.04895 & -0.06767 & -0.06082 & 0.04339 & -0.07071 & 0.15597 & 0.35402 & $2-0.08175$ & $-0.01876-0$ & -0.33203 & 0.73667 \\
\hline $\mathrm{Na}$ & 0.23440 & -0.07096 & 0.09071 & 0.16561 & -0.42196 & 0.07477 & 0.41811 & 0.69702 & 0.11112 & 0.12548 & -0.04808 & -0.07788 & 0.11470 & $0.08091-$ & -0.06205 & 0.00705 \\
\hline $\mathrm{P}$ & 0.29546 & 0.28953 & 0.10391 & -0.16946 & -0.06752 & 0.05485 & -0.06576 & $-0.15787-$ & -0.31845 & 0.06511 & -0.22723 & -0.12574 & 0.71827 & $7-0.15975-c$ & -0.18483 & 0.06217 \\
\hline Al & -0.13214 & $4-0.39113-$ & -0.04580 & 0.52195 & 0.22182 & 0.35554 & 0.07985 & -0.19813 & 0.11961 & 0.02917 & -0.31568 & 0.04709 & 0.33251 & 0.32537 & 0.00222 & -0.01809 \\
\hline $\mathrm{Fe}$ & 0.30028 & -0.34399 & 0.00820 & 0.14460 & 0.08499 & 0.06786 & $6-0.00969$ & $-0.02979-$ & -0.02496 & -0.01265 & 0.13537 & -0.27121 & 0.05326 & -0.54209 & 0.59806 & 0.10333 \\
\hline $\mathrm{Mn}$ & 0.34110 & -0.09838 & 0.05231 & -0.06033 & 0.06213 & 0.05593 & $3-0.04743$ & $3-0.10833-$ & -0.04692 & -0.26562 & 0.25840 & -0.66728 & -0.11423 & 0.47068 & $58-0.16067$ & -0.03770 \\
\hline $\mathrm{Cu}$ & 0.10886 & 0.46910 & -0.18028 & 0.29500 & -0.04223 & 0.29908 & 0.34994 & -0.32225 & 0.09243 & 0.29079 & 0.48351 & 0.04192 & $2-0.03458$ & -0.03289 & 0.00265 & -0.01063 \\
\hline $\mathrm{Ni}$ & 0.12296 & 0.25349 & -0.46369 & 0.16881 & 0.53249 & -0.08399 & 0.05942 & 0.40213 & -0.17586 & -0.40390 & 0.04774 & 0.11588 & 0.10478 & 0.00055 & 0.02236 & -0.00499 \\
\hline $\mathrm{Zn}$ & 0.27949 & 0.01568 & -0.23425 & 0.05723 & 0.26339 & $-0.20910-$ & -0.35379 & 0.14228 & 0.13726 & 0.72384 & -0.14839 & $-0.12971-$ & -0.10259 & 0.09394 & $94-0.06190$ & -0.01326 \\
\hline Groundcover_Per & -0.07441 & $1-0.18445-$ & $-0.00475-0.6$ & 64875 & 0.42931 & 0.32174 & 0.44031 & 0.06858 & 0.04584 & 0.21922 & 0.01972 & -0.00537 & 0.03725 & 0.02383 & 0.01587 & 0.01901 \\
\hline
\end{tabular}

Groundcover_Per c

\section{Scree Plot}




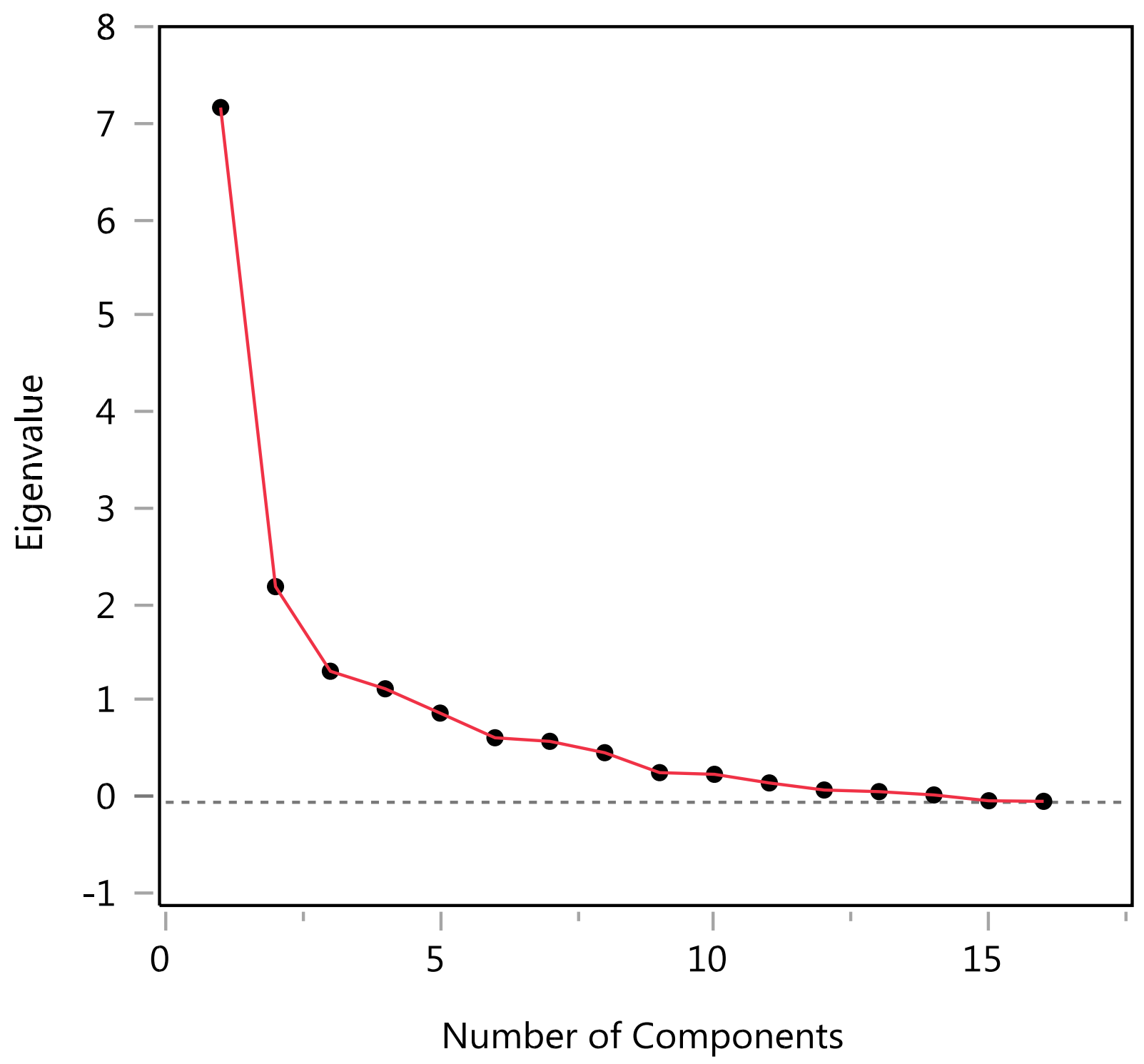

Biplot 


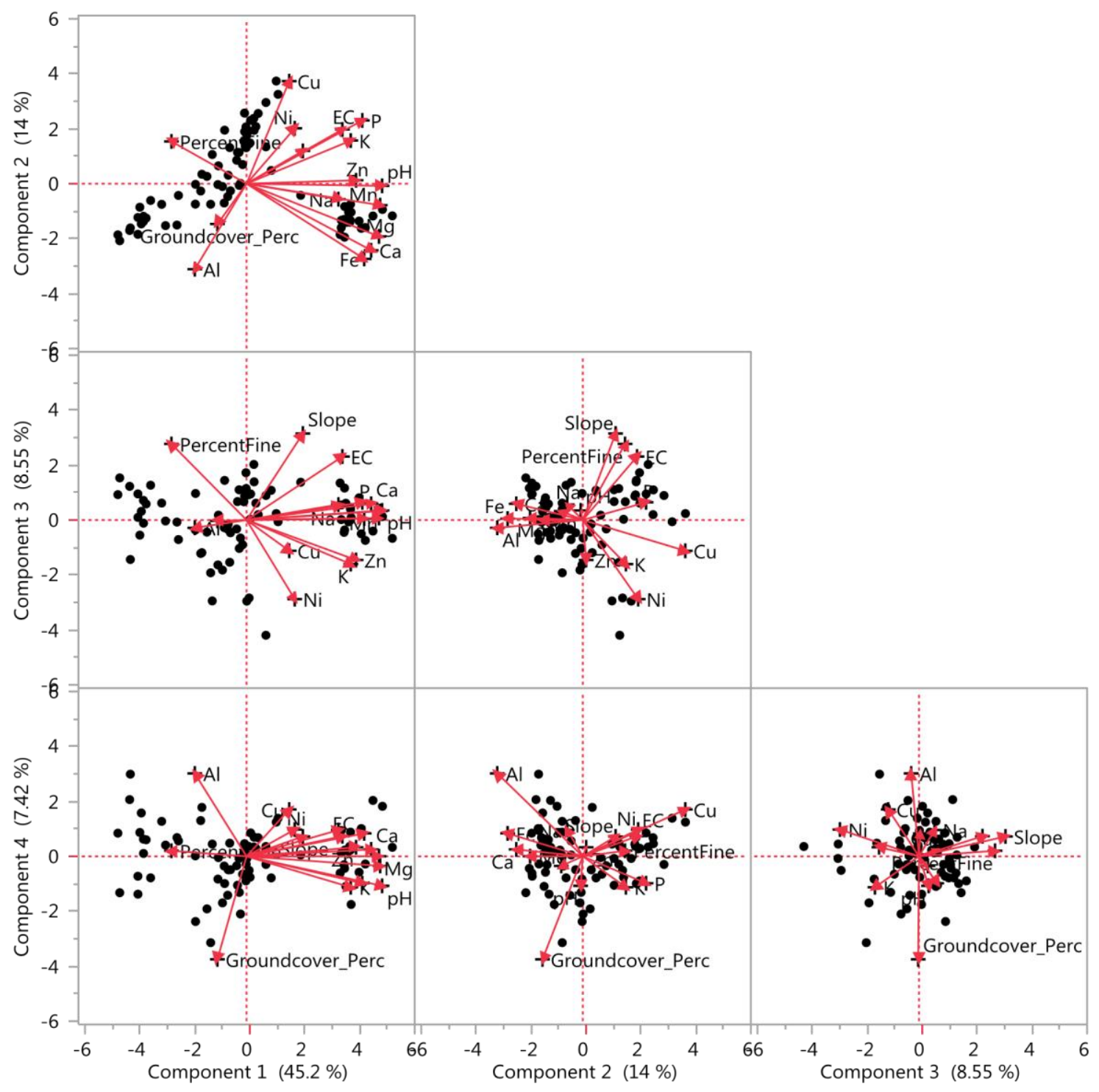

$\square$ Label variables

Principal Components: on Correlations Site=ELK_RUN 


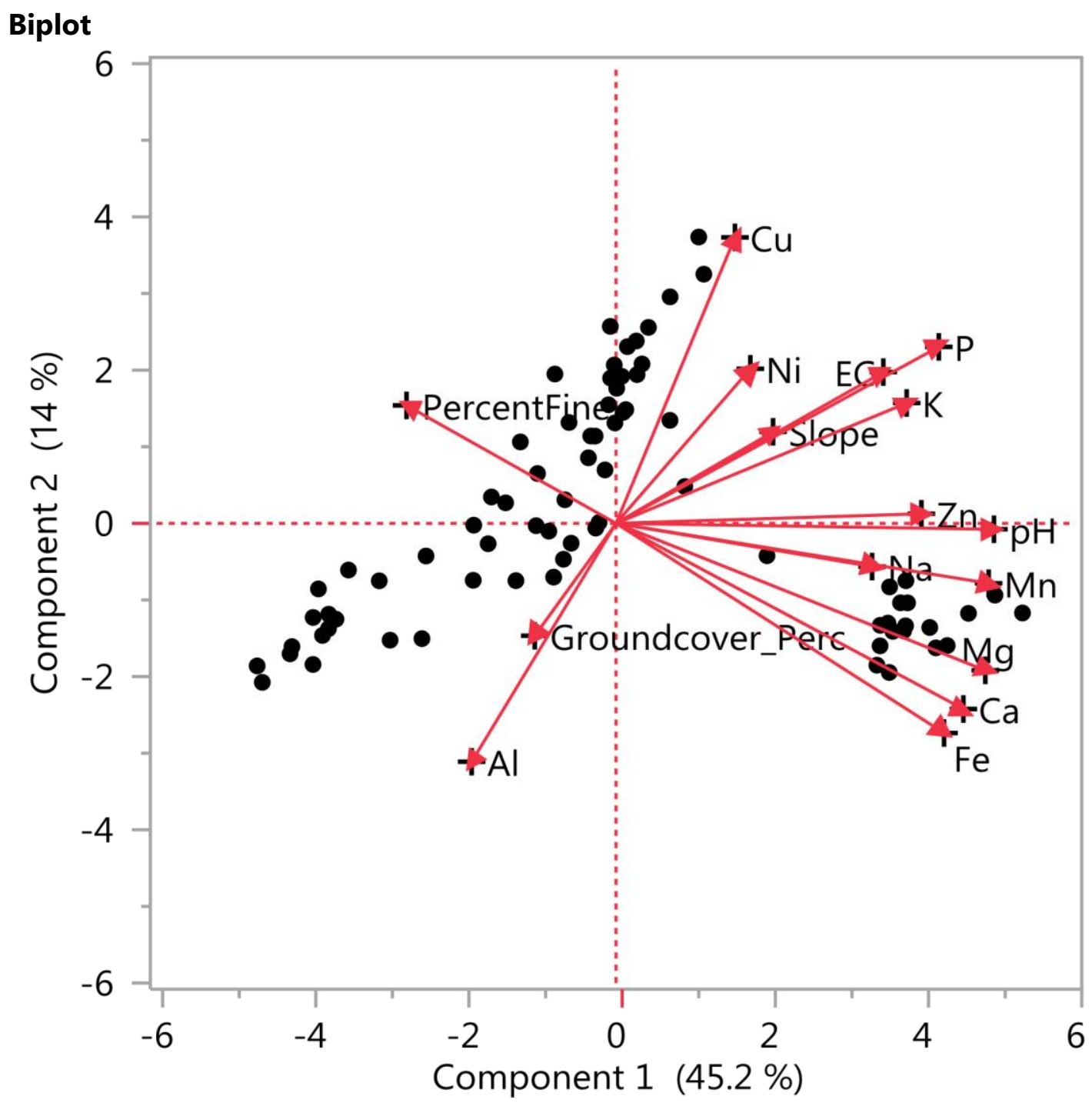

$\checkmark$ Label variables

PCR_Response Normalized_Height Site=ELK_RUN

Whole Model 


\section{Effect Summary}

Source LogWorth

PValue

Prin2 By Site

3.285

0.00052

Prin5 By Site 1.282

0.05221

Prin3 By Site 1.254

0.05570

Prin1 By Site 0.672

0.21283

Prin4 By Site 0.313

0.48591 


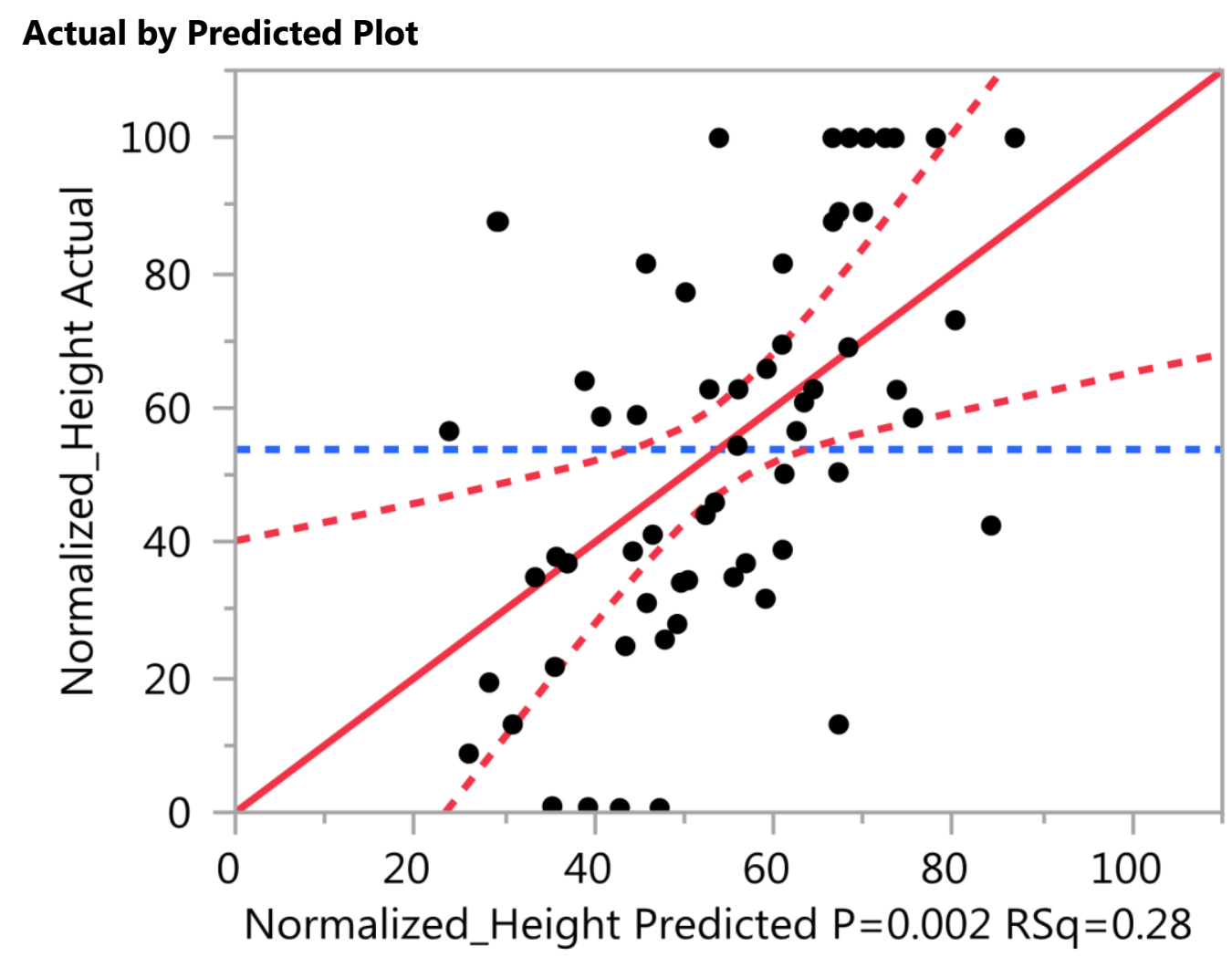

RMSE $=25.911$

\section{Summary of Fit}

$\begin{array}{lr}\text { RSquare } & 0.280566 \\ \text { RSquare Adj } & 0.216331 \\ \text { Root Mean Square Error } & 25.91061 \\ \text { Mean of Response } & 53.79115 \\ \text { Observations (or Sum Wgts) } & 62\end{array}$




\section{Analysis of Variance}

\begin{tabular}{lrrrr} 
Source & DF & $\begin{array}{r}\text { Sum of } \\
\text { Squares }\end{array}$ & Mean Square & F Ratio \\
\hline Model & 5 & 14661.810 & 2932.36 & 4.3678 \\
\hline Error & 56 & 37596.153 & 671.36 & Prob > F \\
\hline C. Total & 61 & 52257.963 & & $0.0020^{*}$
\end{tabular}

\section{Parameter Estimates}

$\begin{array}{lrrrr}\text { Term } & \text { Estimate } & \text { Std Error } & \text { t Ratio } & \text { Prob }>|\mathbf{t}| \\ \text { Intercept } & 55.271818 & 3.320236 & 16.65 & <.0001^{*} \\ \text { Prin3 By Site } & -6.019707 & 3.080657 & -1.95 & 0.0557 \\ \text { Prin4 By Site } & -2.215262 & 3.157996 & -0.70 & 0.4859 \\ \text { Prin5 By Site } & -6.813757 & 3.4351 & -1.98 & 0.0522 \\ \text { Prin1 By Site } & 1.4911697 & 1.183304 & 1.26 & 0.2128 \\ \text { Prin2 By Site } & 8.1452698 & 2.211034 & 3.68 & 0.0005^{*}\end{array}$

\section{Residual by Predicted Plot}




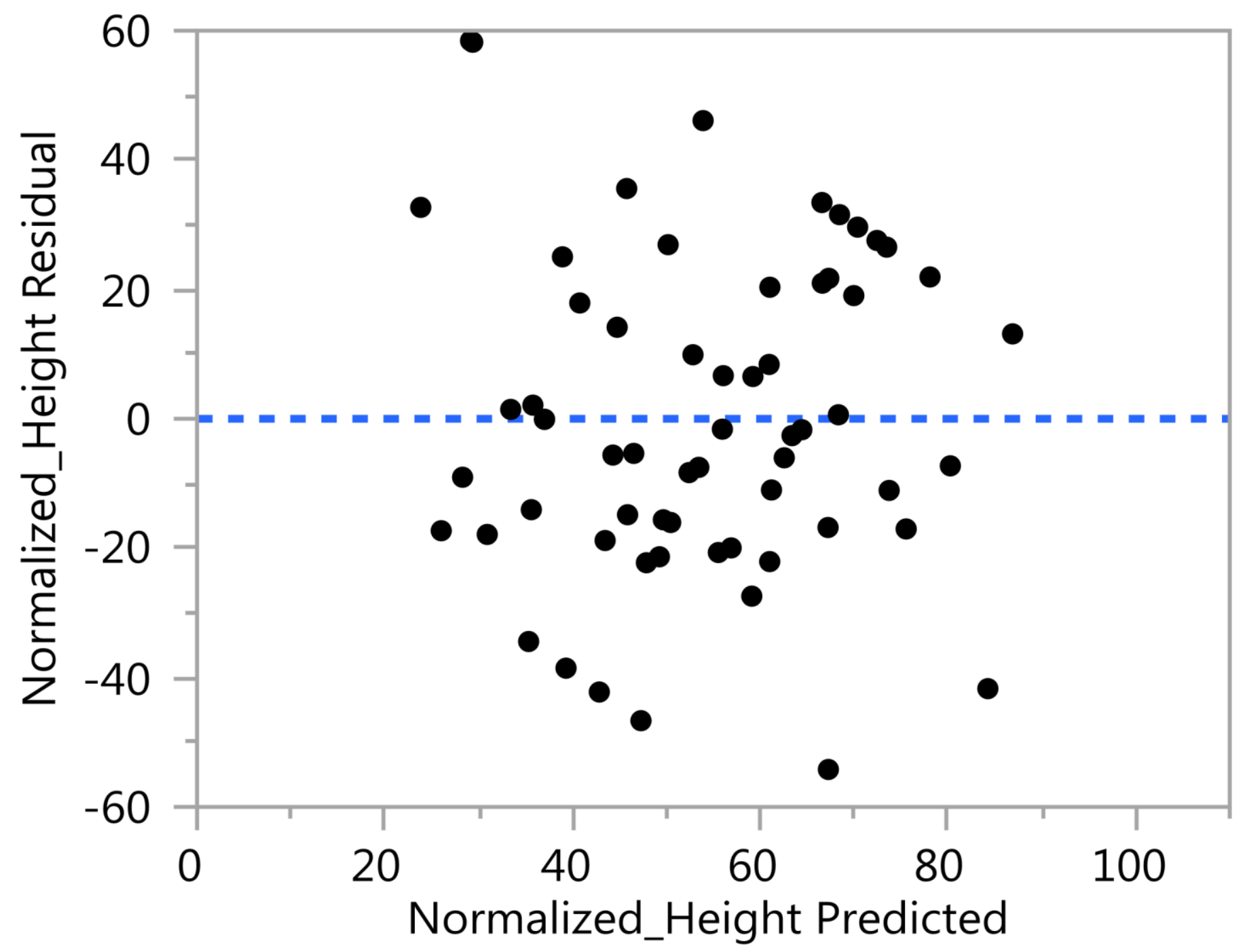


Principal Components: on Correlations Site=FOLA

\section{Summary Plots}
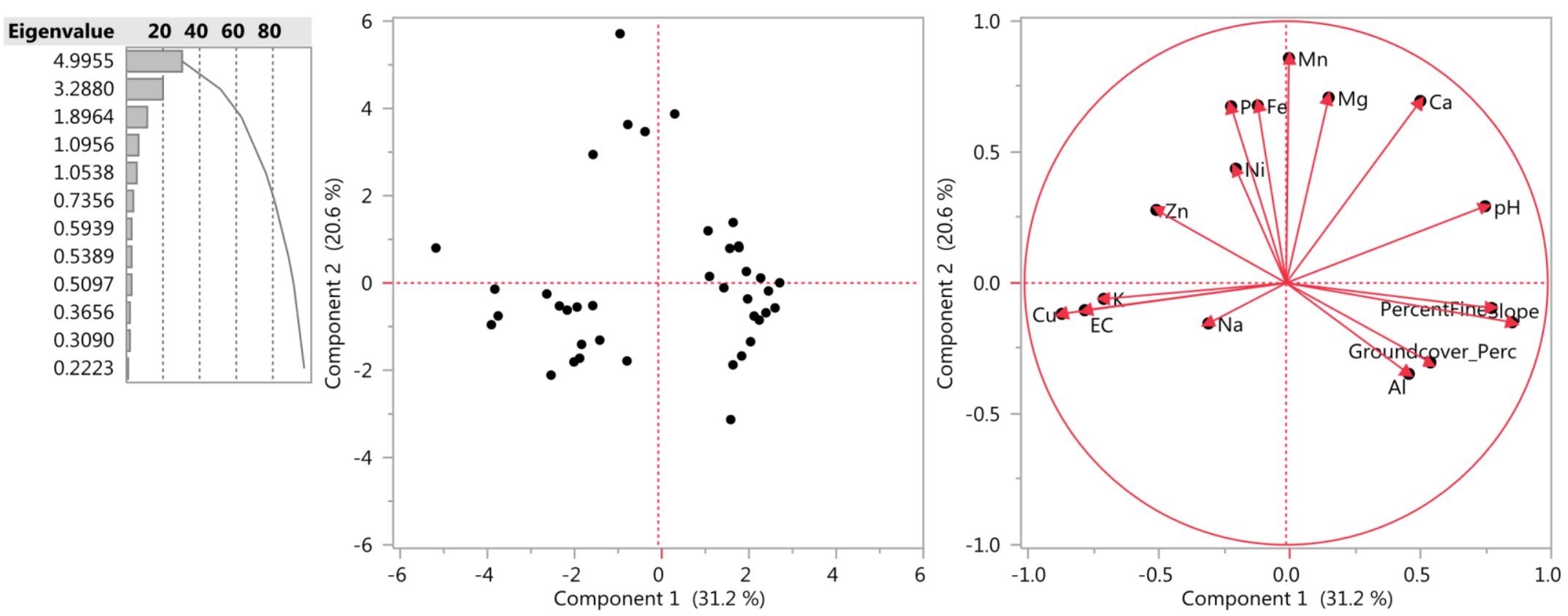

$\checkmark$ Label variables

Eigenvalues

\begin{tabular}{rrrrrrrrr} 
Number & Eigenvalue & \multicolumn{1}{l}{ Percent } & & & Cum Percent & ChiSquare & DF & Prob>ChiSq \\
1 & 4.9955 & 31.222 & & 31.222 & 401.098 & 119.767 & $<.0001^{*}$ \\
2 & 3.2880 & 20.550 & $\vdots$ & 51.772 & 292.445 & 112.763 & $<.0001^{*}$ \\
3 & 1.8964 & $11.852 \square$ & $\vdots$ & 63.625 & 205.209 & 103.059 & $<.0001^{*}$ \\
4 & 1.0956 & 6.847 & $\vdots$ & $\vdots$ & 70.472 & 154.284 & 91.430 & $<.0001^{*}$ \\
5 & 1.0538 & 6.586 & $\vdots$ & $\vdots$ & 77.058 & 130.882 & 79.327 & $0.0002^{*}$
\end{tabular}




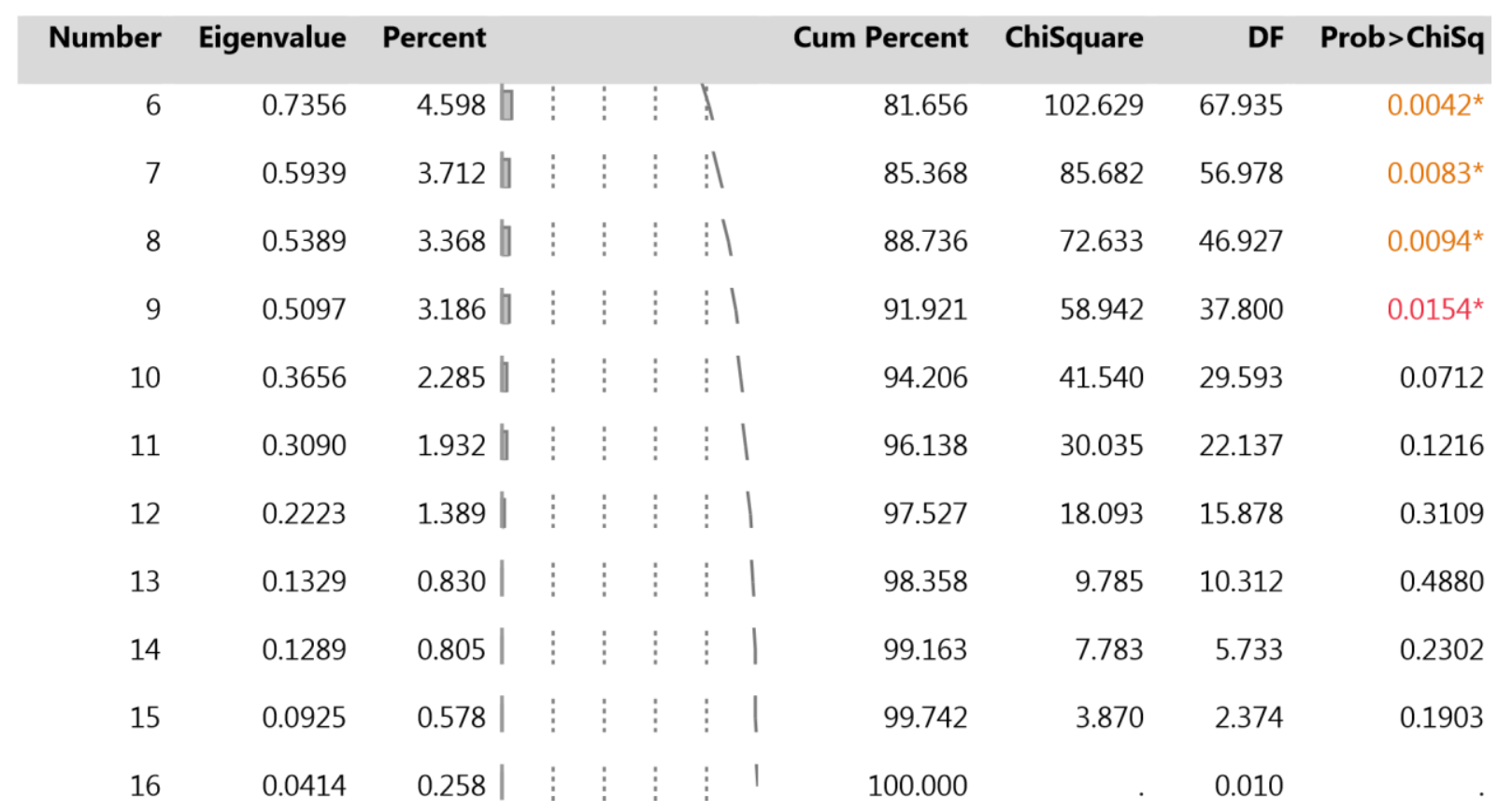

\begin{tabular}{|c|c|c|c|c|c|c|c|c|c|c|c|c|c|c|c|c|}
\hline & Prin1 & Prin2 & Prin3 & Prin4 & Prin5 & Prin6 & Prin7 & Prin8 & Prin9 & Prin10 & Prin11 & Prin12 & Prin13 & Prin14 & Prin15 & Prin16 \\
\hline \multirow[t]{2}{*}{ Slope } & 0.38640 & - & & 0.04471 & & .14685 & & 0.26799 & 0.21092 & & 0.28105 & & -0.25905 & 0.559250 & .32870 & \\
\hline & & 0.08277 & 0.04295 & & 0.10581 & & 0.22906 & & & 0.20787 & & 0.16809 & & & & 0.00966 \\
\hline \multirow[t]{2}{*}{ PercentFine } & 0.35127 & & -0.02492 & 0.195410 & 0.106510 .1 & 17796 & & 0.27302 & & 0.71376 & 0.167730 & 0.06203 & - & & & \\
\hline & & 0.05256 & & & & & 0.28003 & & 0.07670 & & & & 0.22186 & 0.14644 & 0.102570 & 0.10280 \\
\hline \multirow[t]{2}{*}{$\mathrm{pH}$} & 0.34017 & 0.16163 & & 0.21784 & 0.06810 & - & - & - & & & & -0.31215 & 0.53457 & & & 0.17270 \\
\hline & & & 0.17489 & & & 0.1738 & 70.25977 & 0.40220 & 0.045870 & 0.006410. & .04019 & & & 0.02842 & 0.31370 & \\
\hline \multirow[t]{2}{*}{ EC } & - & & 0.23086 & & -0.091510 & 0.15134 & 0.047400. & .57463 & & -0.01725 & 0.081170 & 0.295810 & .48236 & & & 0.21577 \\
\hline & 0.34446 & 0.05726 & & 0.09398 & & & & & 0.21391 & & & & & 0.00160 & 0.18122 & \\
\hline
\end{tabular}




\begin{tabular}{|c|c|c|c|c|c|c|c|c|c|c|c|c|c|c|c|c|}
\hline & Prin1 & Prin2 & Prin3 & Prin4 & Prin5 & Prin6 & Prin7 & Prin8 & Prin9 & Prin10 & Prin11 & Prin12 & Prin13 & Prin14 & Prin15 & Prin16 \\
\hline \multirow[t]{2}{*}{$\mathrm{K}$} & - & - & - & & -0.34427 & 0.113590 & 0.06293 & & -0.3645 & 570.24245 & 50.19063 & 0.23719 & 0.204400. & 140310.0 & 06633 & - \\
\hline & 0.31201 & 0.03341 & 0.298130 & 0.22439 & & & & 0.18287 & & & & & & & & 0.49327 \\
\hline \multirow[t]{2}{*}{$\mathrm{Ca}$} & 0.22953 & 0.38339 & - & & -0.35612 & 0.02175 & 0.094350 & 0.12444 & - & & -0.11952 & 0.16799 & 0.03898 & & -0.58078 & 0.02259 \\
\hline & & & 0.08237 & 0.04901 & & & & & 0.13220 & 0.18846 & & & & 0.45235 & & \\
\hline \multirow[t]{2}{*}{$\mathrm{Mg}$} & 0.07277 & 0.39060 & 0.06584 & & - 0.10275 & 0.205290 & 0.09829 & - & & 0.25979 & - & & -0.06165 & 0.39418 & 0.004240 & 0.04332 \\
\hline & & & & 0.42777 & & & & 0.22195 & 0.50324 & & 0.09534 & 0.22867 & & & & \\
\hline \multirow[t]{2}{*}{$\mathrm{Na}$} & - & & -0.39685 & 0.09353 & 0.63882 & & - & - & & & -0.04752 & 0.07929 & & 0.22064 & & 0.12376 \\
\hline & 0.13290 & 0.08516 & & & & 0.0150 & 50.40427 & 70.15364 & 0.014890 & 0.22643 & & & 0.29609 & & 0.04231 & \\
\hline \multirow[t]{2}{*}{$P$} & & 0.37213 & 0.36807 & 0.39450 & 0.00962 & & -0.012010 & 0.06938 & - & & 0.06647 & & - 0.23147 & & - & - \\
\hline & 0.09418 & & & & & 0.14531 & & & 0.05161 & 0.06500 & & 0.35408 & & 0.05999 & 0.12436 & 0.57102 \\
\hline \multirow[t]{2}{*}{$\mathrm{Al}$} & 0.20979 & & - 0.07449 & 0.35268 & 80.288650 & 0.494920 & .61042 & & 0.10501 & - & & & -0.07815 & 0.01141 & & 0.13281 \\
\hline & & 0.19142 & & & & & & 0.14270 & & 0.03478 & B 0.02178 & 0.12165 & & & 0.12958 & \\
\hline \multirow[t]{2}{*}{$\mathrm{Fe}$} & & 0.37380 & 0.358760 & 0.18989 & & -0.09721 & 0.09659 & & -0.321690 & 0.18588 & & 0.48143 & & -0.24819 & 0.24341 & 0.07305 \\
\hline & 0.04860 & & & & 0.25548 & & & 0.04611 & & & 0.31504 & & 0.10825 & & & \\
\hline \multirow[t]{2}{*}{$\mathrm{Mn}$} & & & 0.004700 & 0.47363 & & -0.0745 & & -0.10369 & 90.11852 & 0.48235 & 0.036210. & .38045 & - & & - & 0.36878 \\
\hline & & & 0.014410 & 0.18912 & 0.12203 & 0.20106 & 0.122470 & 0.038310 .3 & 35046 & & & & & & & \\
\hline \multirow[t]{2}{*}{$\mathrm{Cu}$} & - & - & & 0.28316 & 0.06261 & & & & -0.067680 & 0.38341 & & & -0.25755 & & 0.41621 & 0.40544 \\
\hline & 0.38357 & $0.06491 \mathrm{c}$ & 0.05002 & & & 0.13105 & 50.106110 & 0.15896 & & & 0.01010 & 0.38836 & & 0.04368 & & \\
\hline \multirow[t]{2}{*}{$\mathrm{Ni}$} & -( & 0.24079 & & -0.16827 & 70.227960 & 0.15324 & & 0.351430 & 0.08889 & - & - & - & & 0.10198 & - & \\
\hline & 0.08612 & & 0.49038 & & & & 0.17509 & & & 0.09979 & 90.60215 & 0.15234 & 0.06718 & & 0.13264 & 0.00621 \\
\hline \multirow[t]{2}{*}{$\mathrm{Zn}$} & -( & 0.15384 & & 0.44267 & & & -0.19228 & 0.02801 & - & & 0.40849 & 0.22959 & & 0.31627 & & 0.04515 \\
\hline & 0.22201 & & 0.37504 & & 0.06110 & 0.13018 & & & 0.36776 & 0.05072 & & & 0.26904 & & 0.01256 & \\
\hline Groundcover_ & 0.24668 & & 0.05088 & & 0.29427 & & -0.37644 & 0.221320 & 0.018400. & .18194 & & -0.02794 & 40.02891 & 0.239750 & 0.03706 & \\
\hline Perc & & 0.16739 & & 0.05247 & & 0.69992 & & & & & 0.21039 & & & & & 0.02108 \\
\hline
\end{tabular}

\section{Scree Plot}




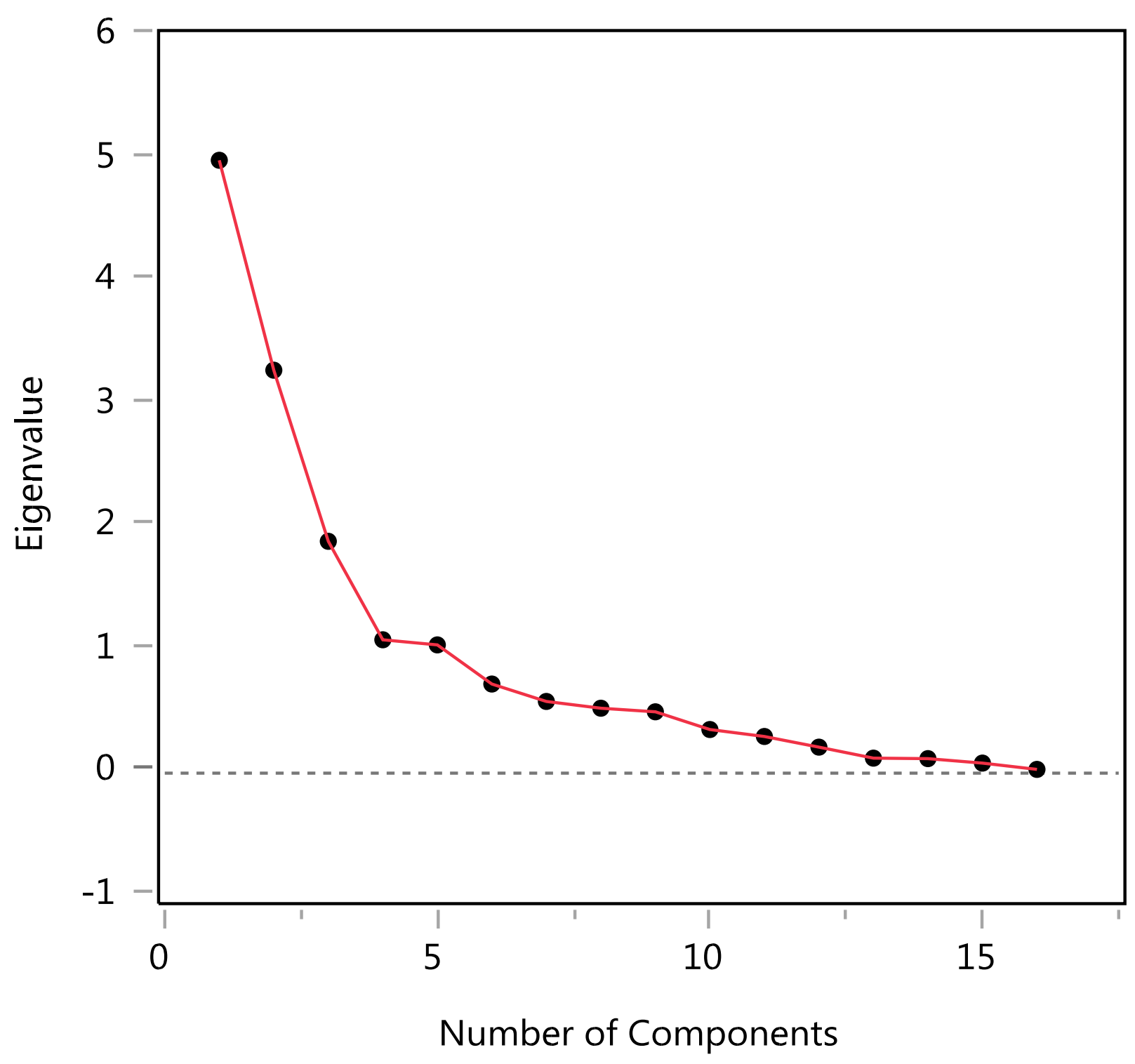

Biplot 


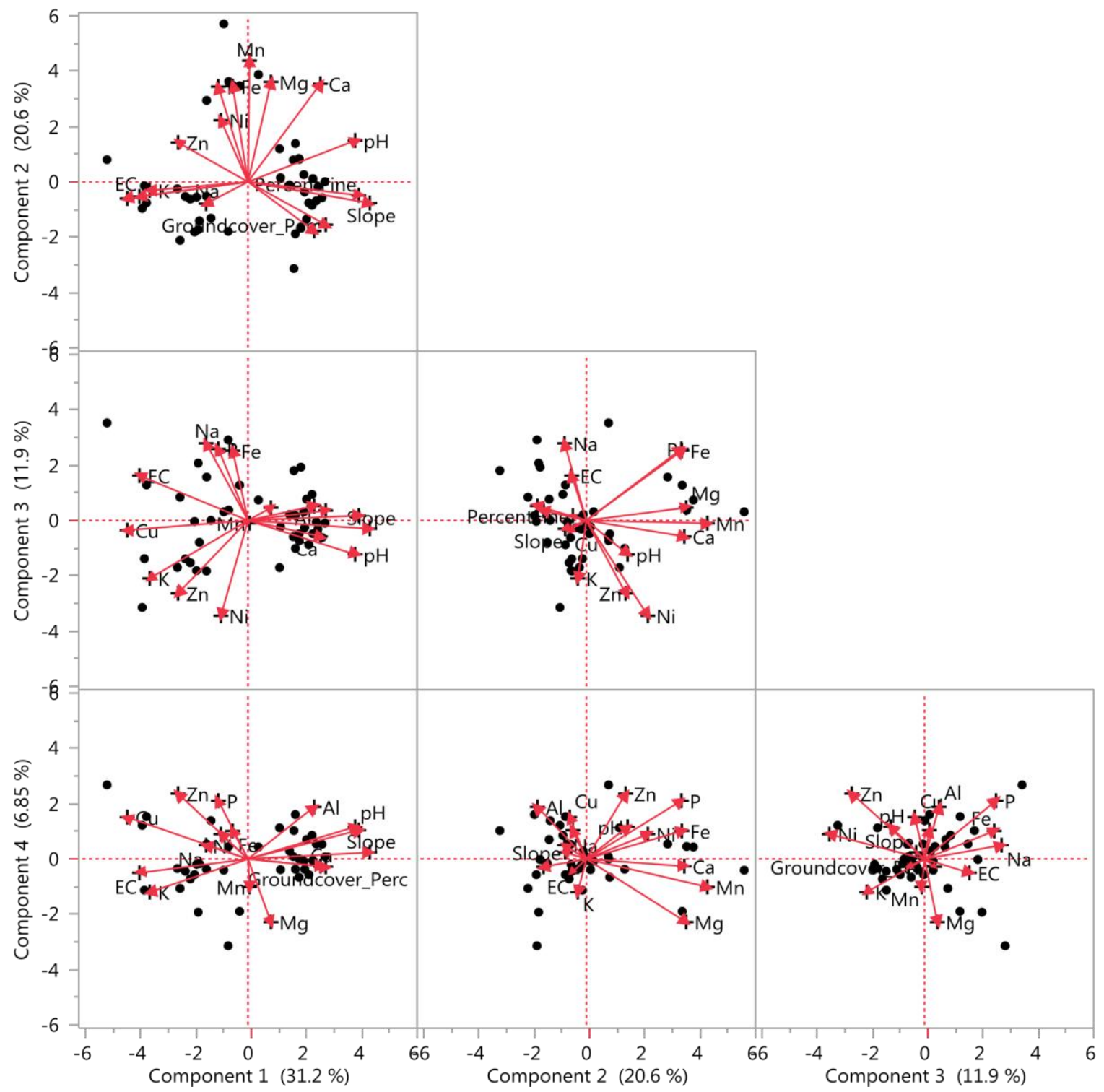

Principal Components: on Correlations Site $=$ FOLA 
Biplot

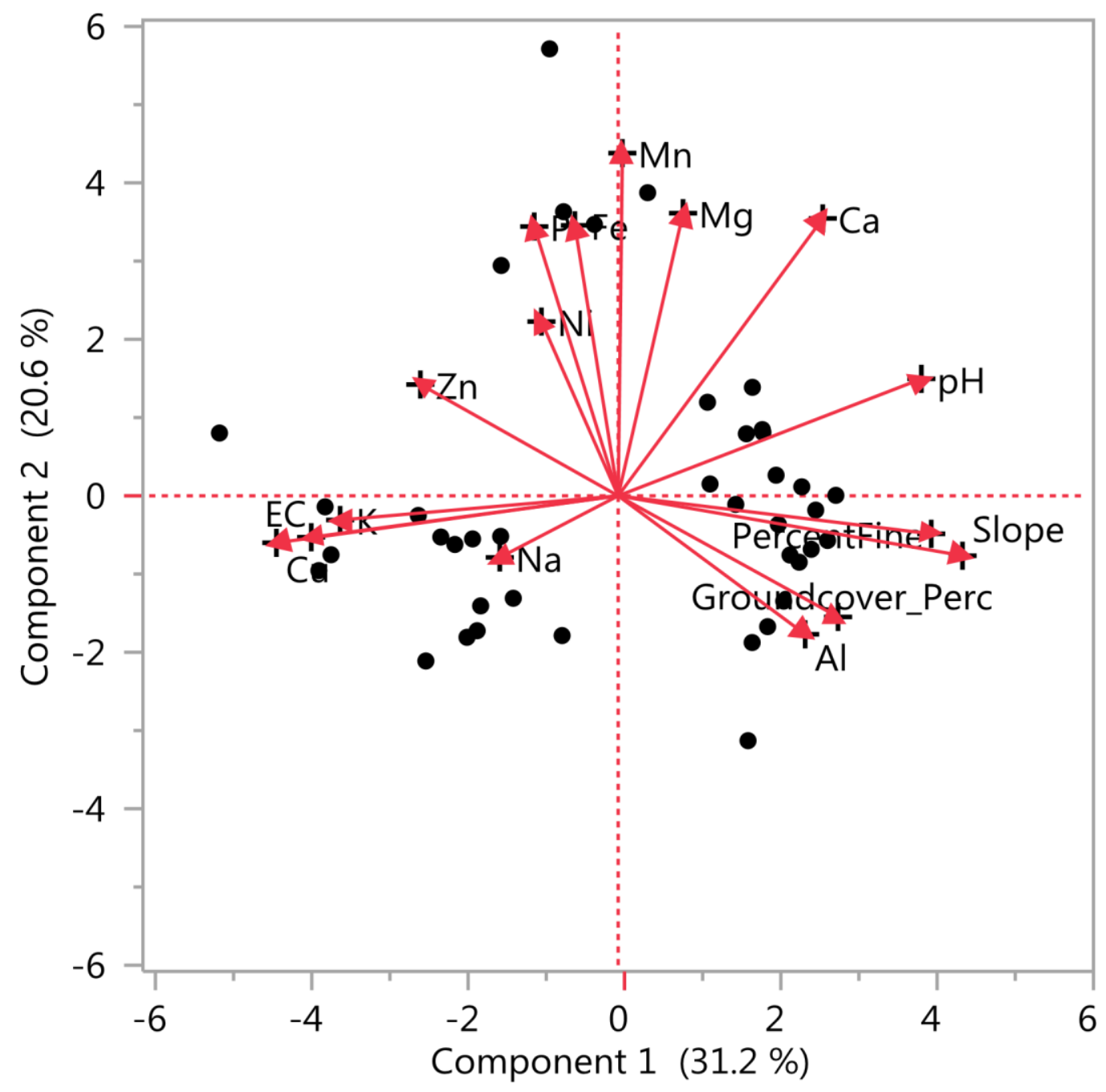

$\checkmark$ Label variables

PCR Response Normalized_Height Site=FOLA

Whole Model 


\section{Effect Summary}

Prin1 By Site

Prin5 By Site

Prin4 By Site 0.082

Site $0.077 \quad 0.83727$

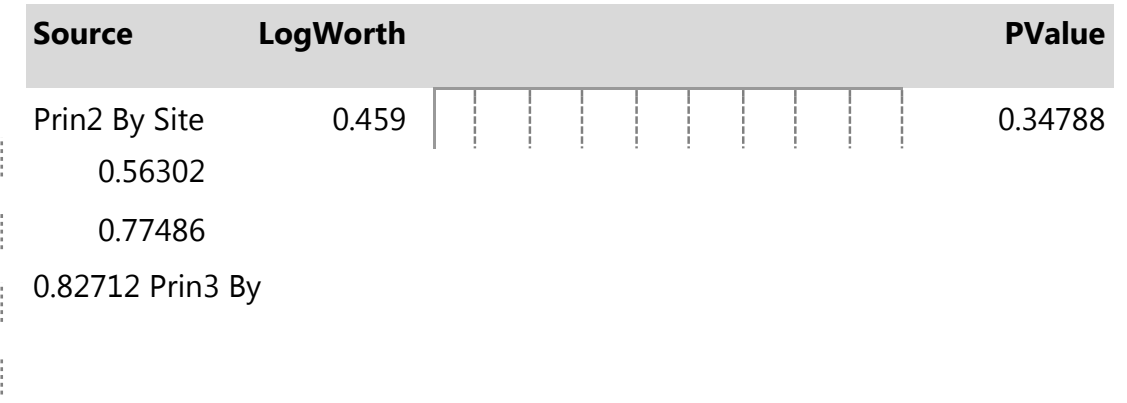




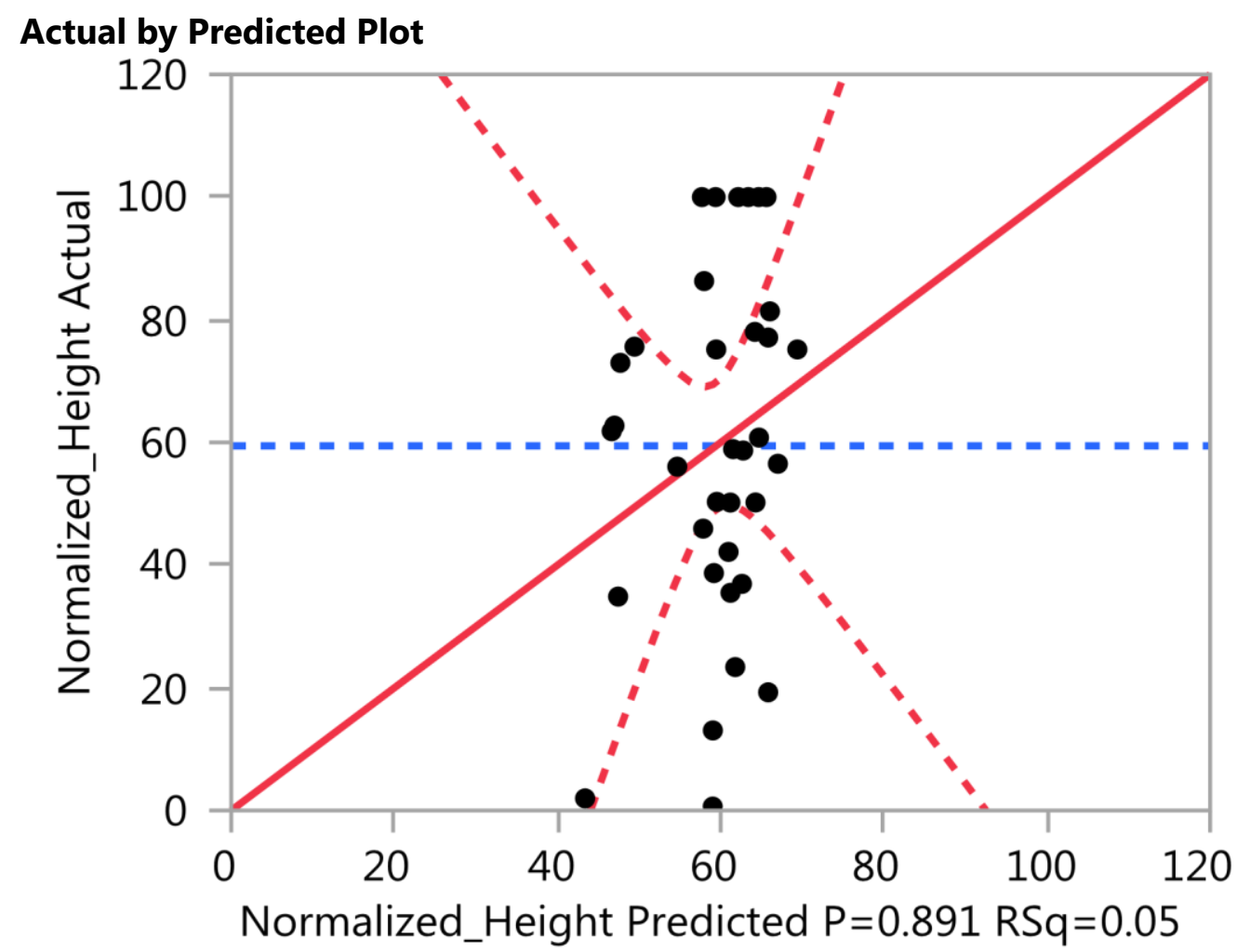

RMSE $=29.895$

\section{Summary of Fit}

RSquare

RSquare Adj

Root Mean Square Error

Mean of Response

Observations (or Sum Wgts)
0.053765

$-0.10938$

29.8946

59.43483

35 


\section{Analysis of Variance}

\begin{tabular}{lrrrr} 
Source & DF & $\begin{array}{r}\text { Sum of } \\
\text { Squares }\end{array}$ & Mean Square & F Ratio \\
\hline Model & 5 & 1472.597 & 294.519 & 0.3296 \\
\hline Error & 29 & 25916.929 & 893.687 & Prob > F \\
\hline C. Total & 34 & 27389.526 & & 0.8910
\end{tabular}

\section{Parameter Estimates}

$\begin{array}{lrrrr}\text { Term } & \text { Estimate } & \text { Std Error } & \text { t Ratio } & \text { Prob }>|\mathbf{t}| \\ \text { Intercept } & 59.670369 & 5.187847 & 11.50 & <.0001^{*} \\ \text { Prin3 By Site } & -0.773467 & 3.73232 & -0.21 & 0.8373 \\ \text { Prin4 By Site } & -1.108925 & 5.031986 & -0.22 & 0.8271 \\ \text { Prin5 By Site } & 1.7398395 & 6.026233 & 0.29 & 0.7749 \\ \text { Prin1 By Site } & 1.3760332 & 2.351865 & 0.59 & 0.5630 \\ \text { Prin2 By Site } & -2.720424 & 2.851058 & -0.95 & 0.3479\end{array}$

\section{Residual by Predicted Plot}




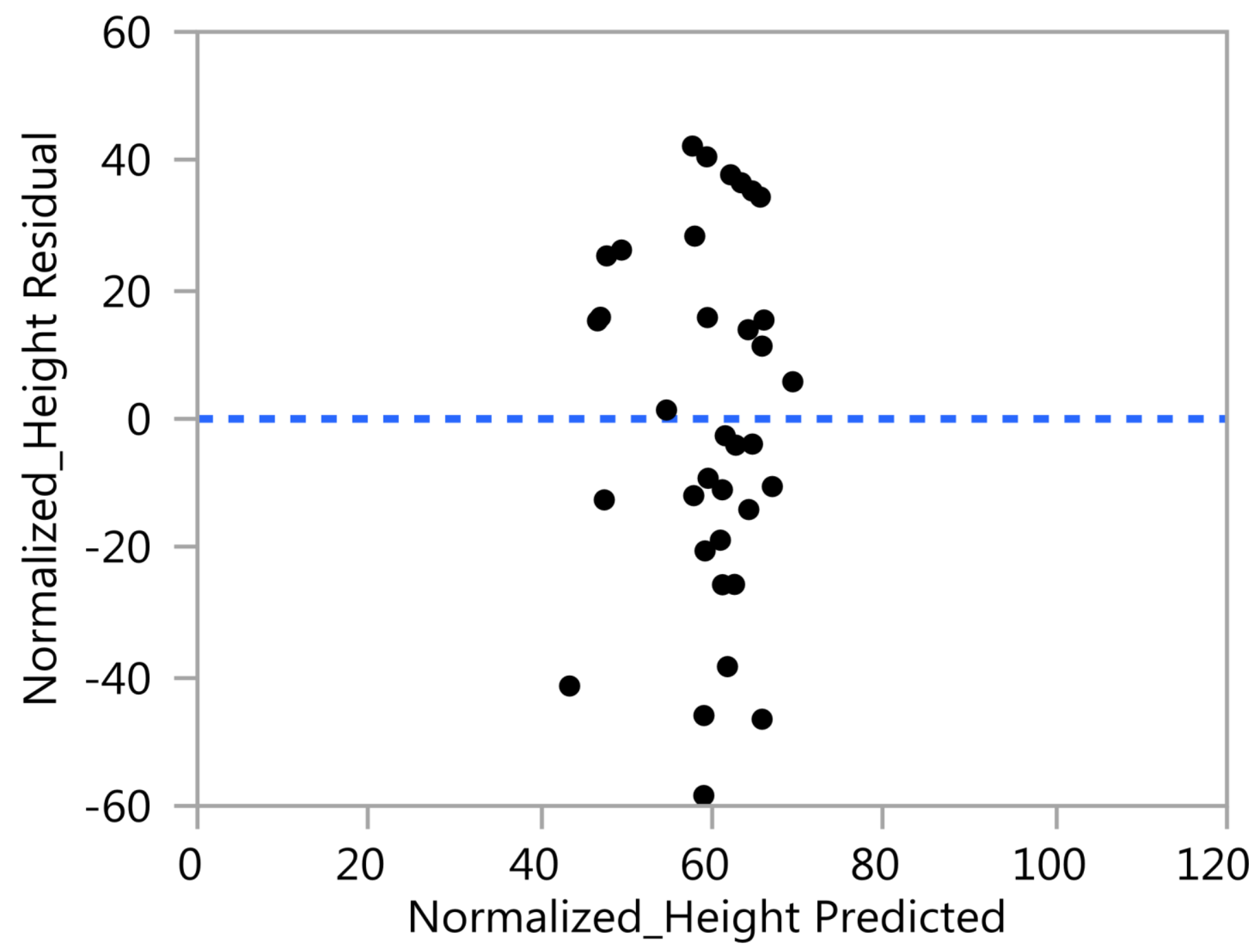


Principal Components: on Correlations Site $=$ HOBET

\section{Summary Plots}
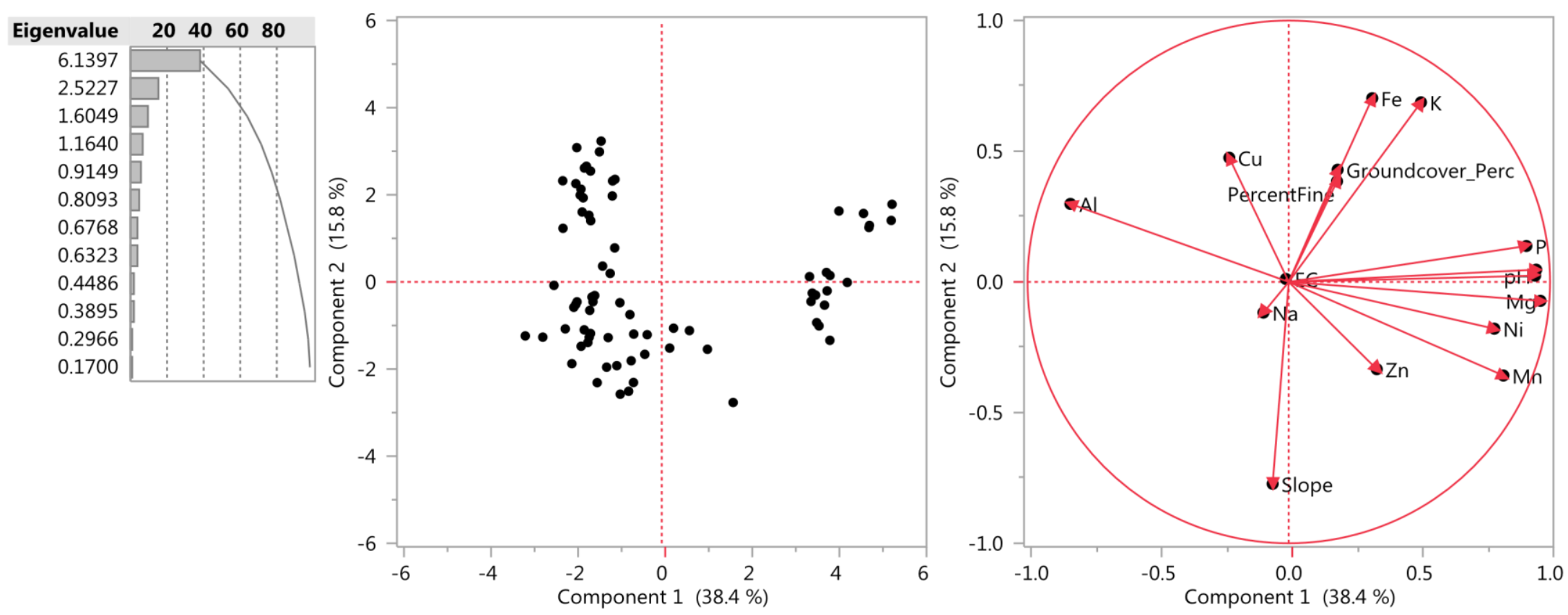

$\checkmark$ Label variables

\section{Eigenvalues}

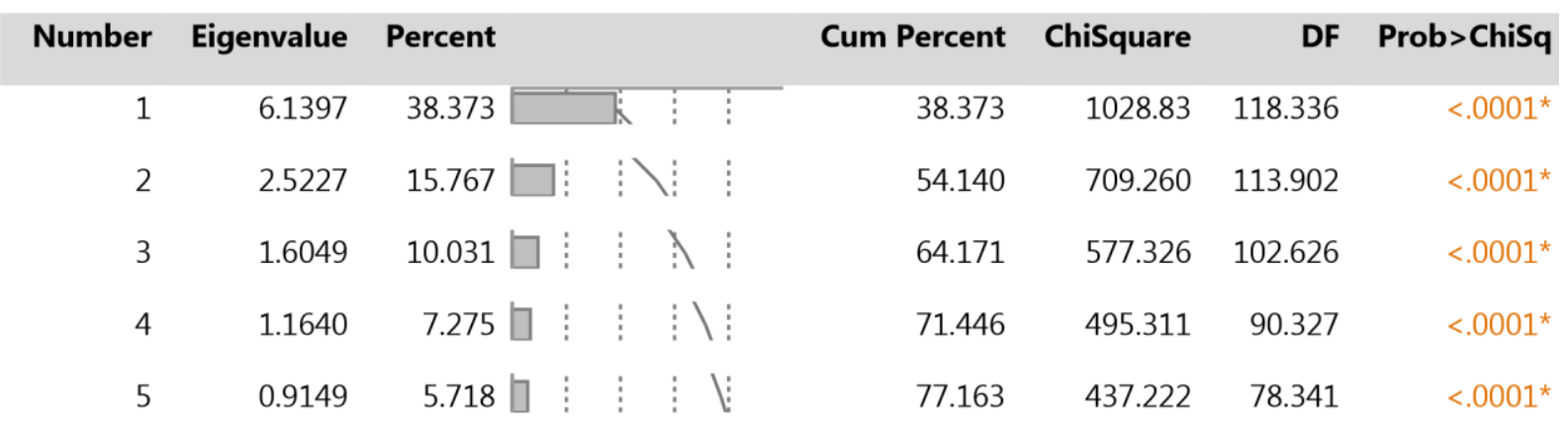




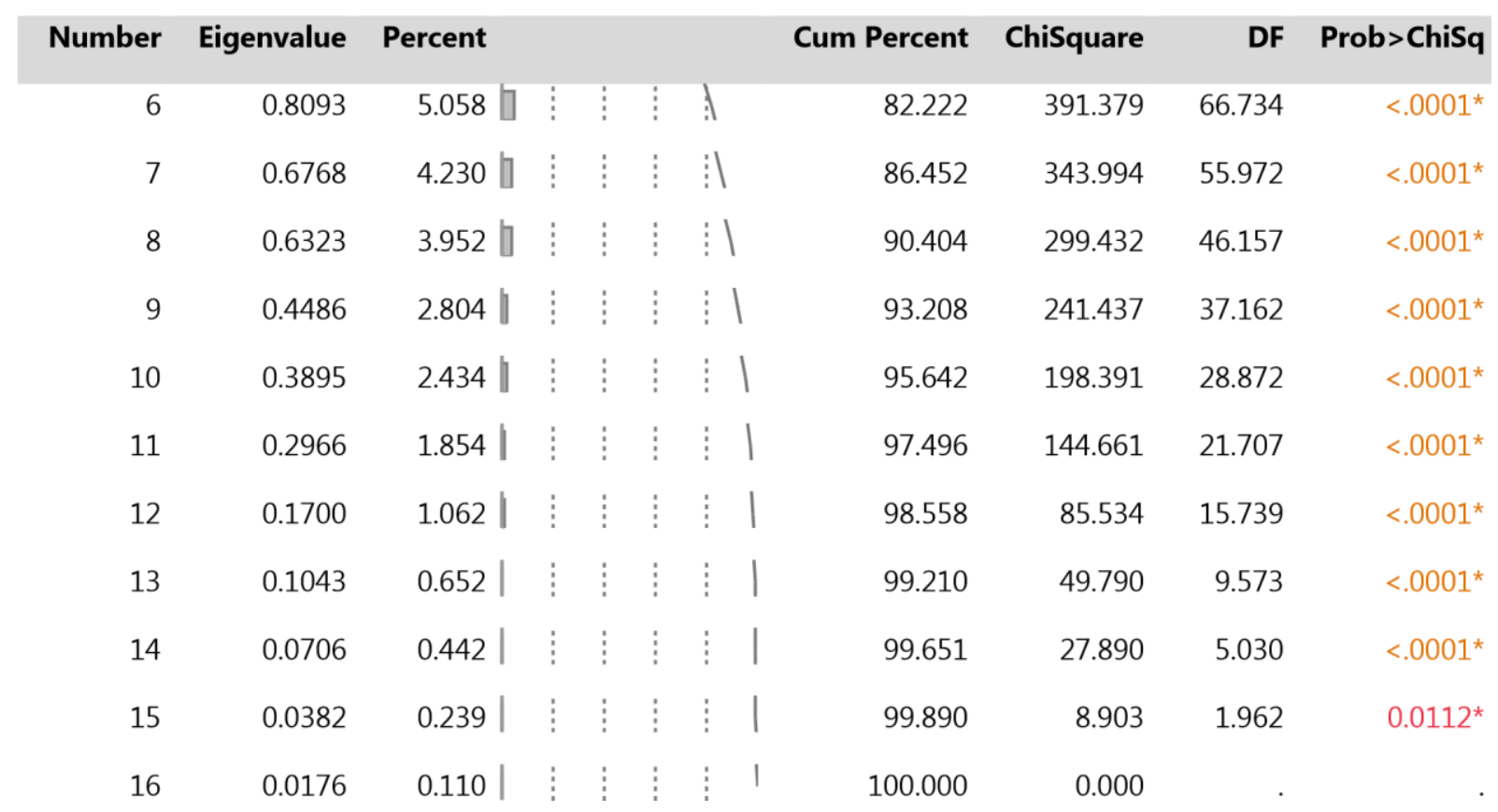

\section{Eigenvectors}

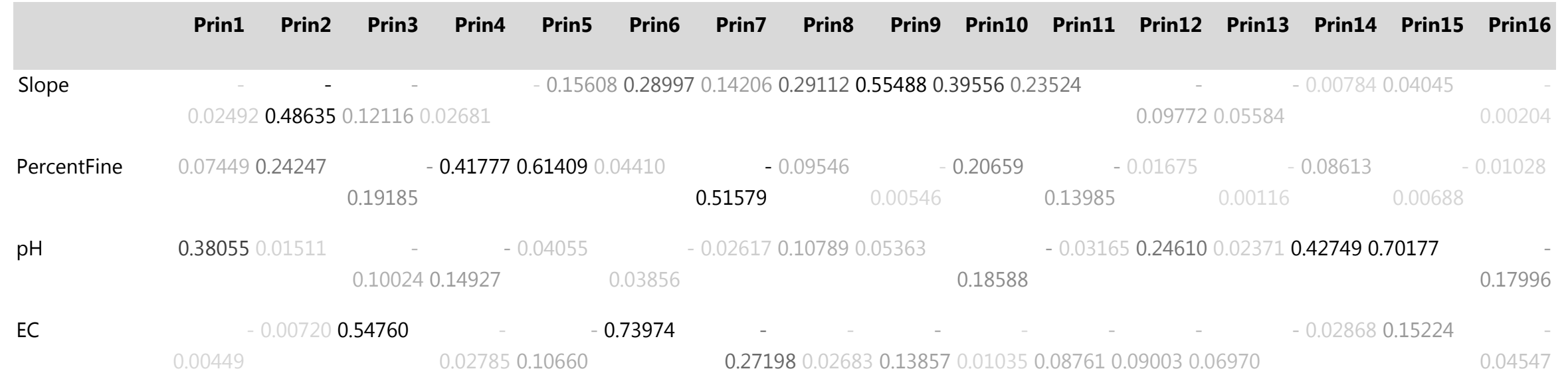




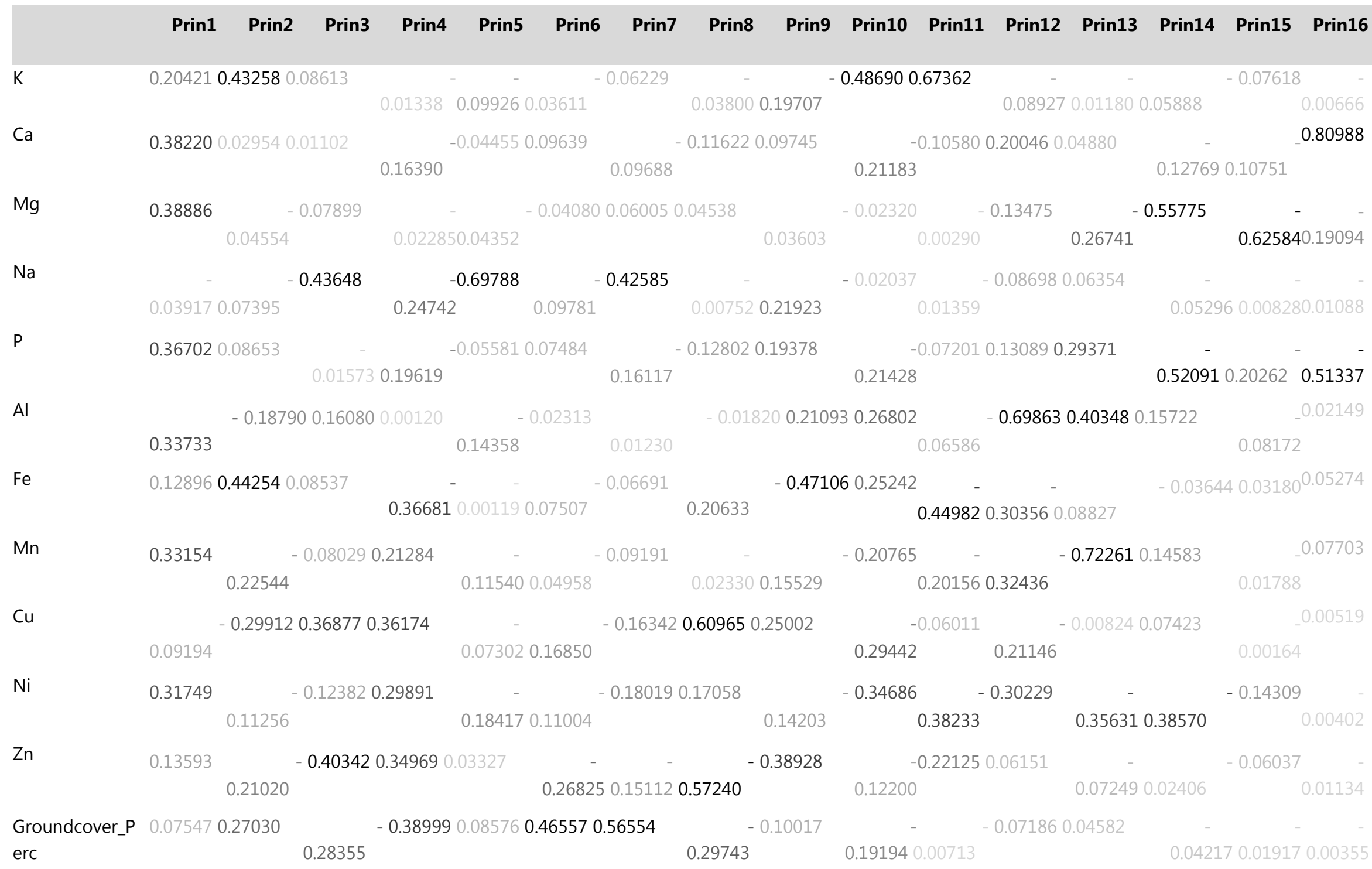

\section{Scree Plot}




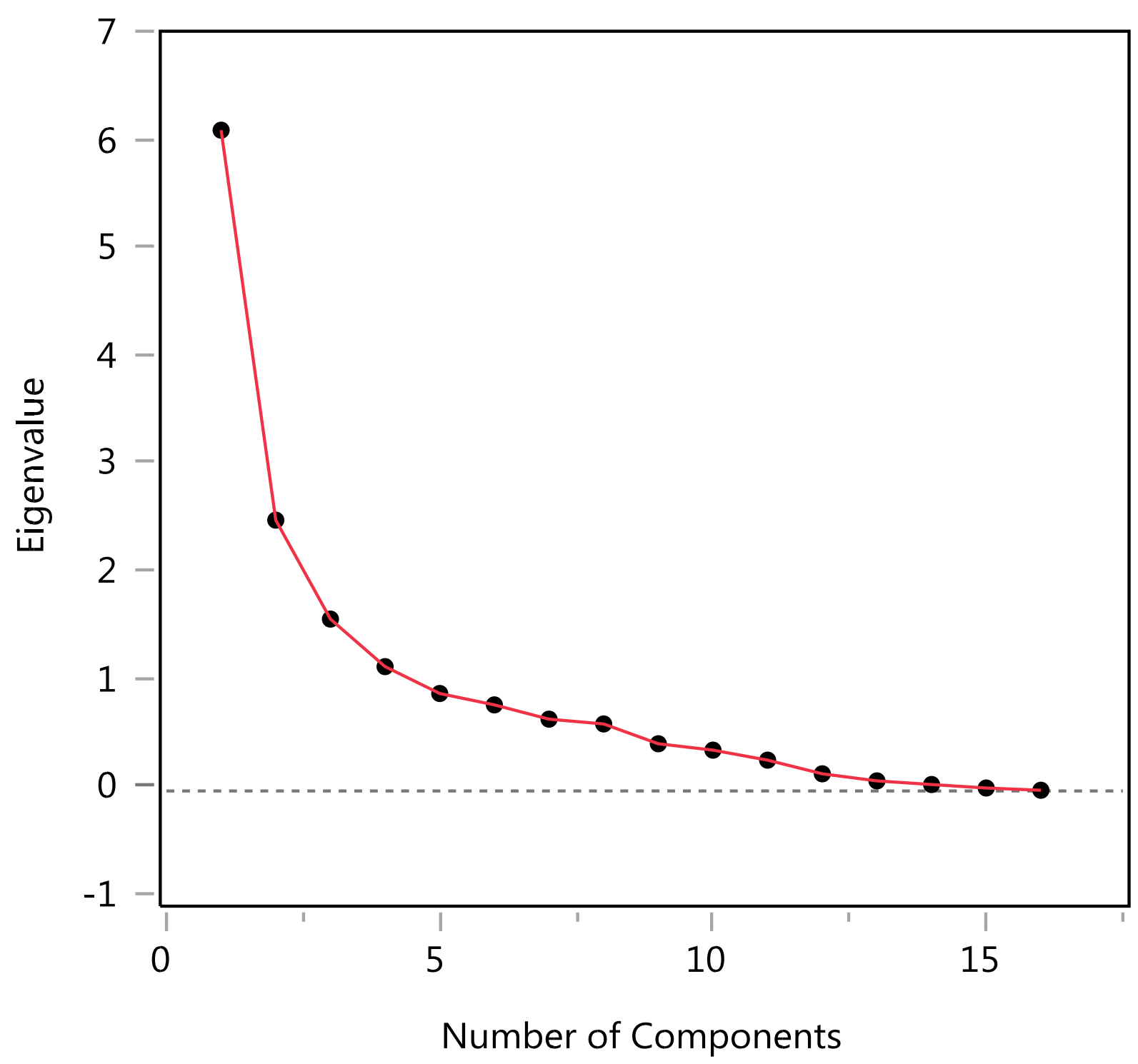

Biplot 


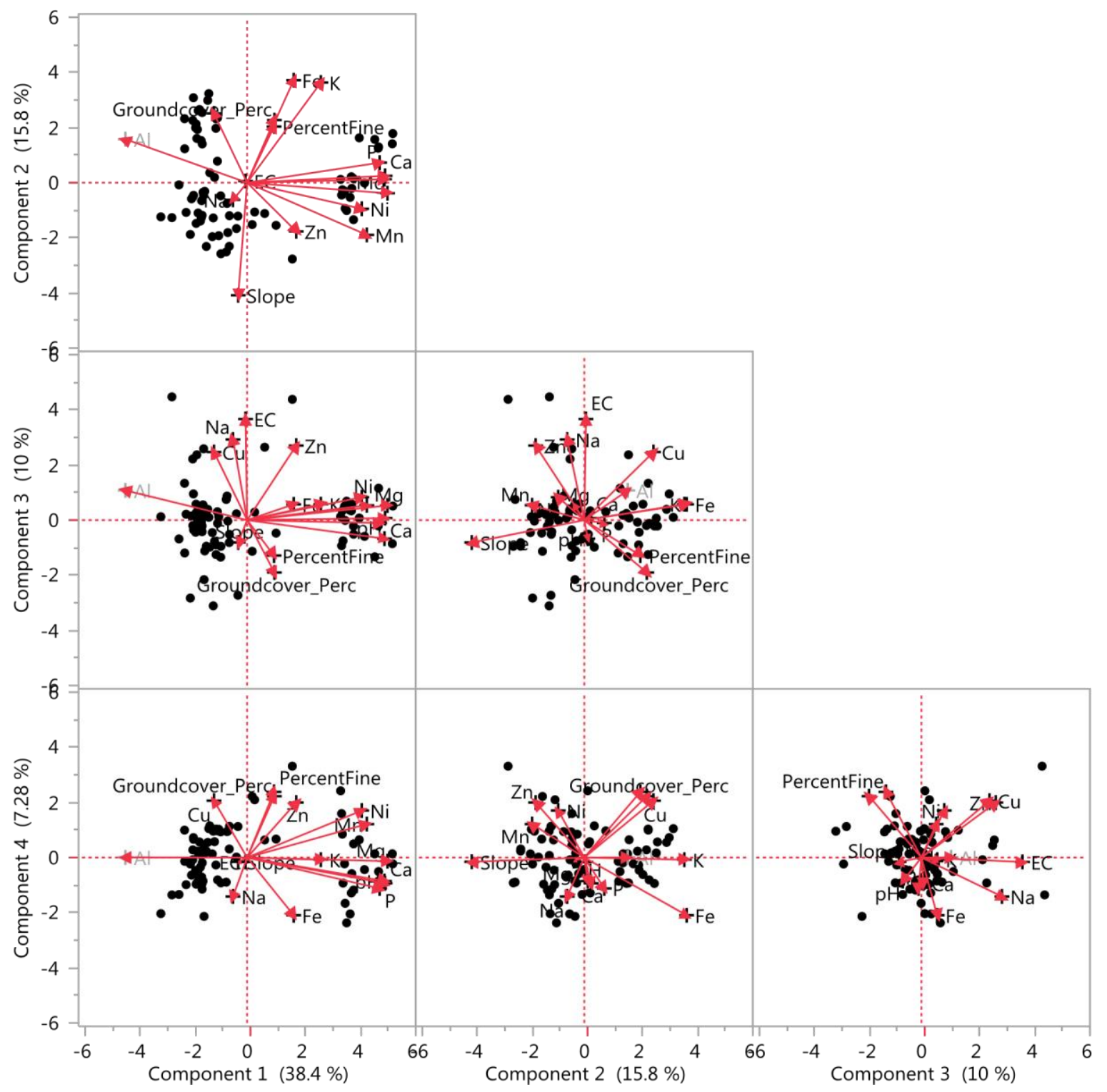

Principal Components: on Correlations Site $=$ HOBET 


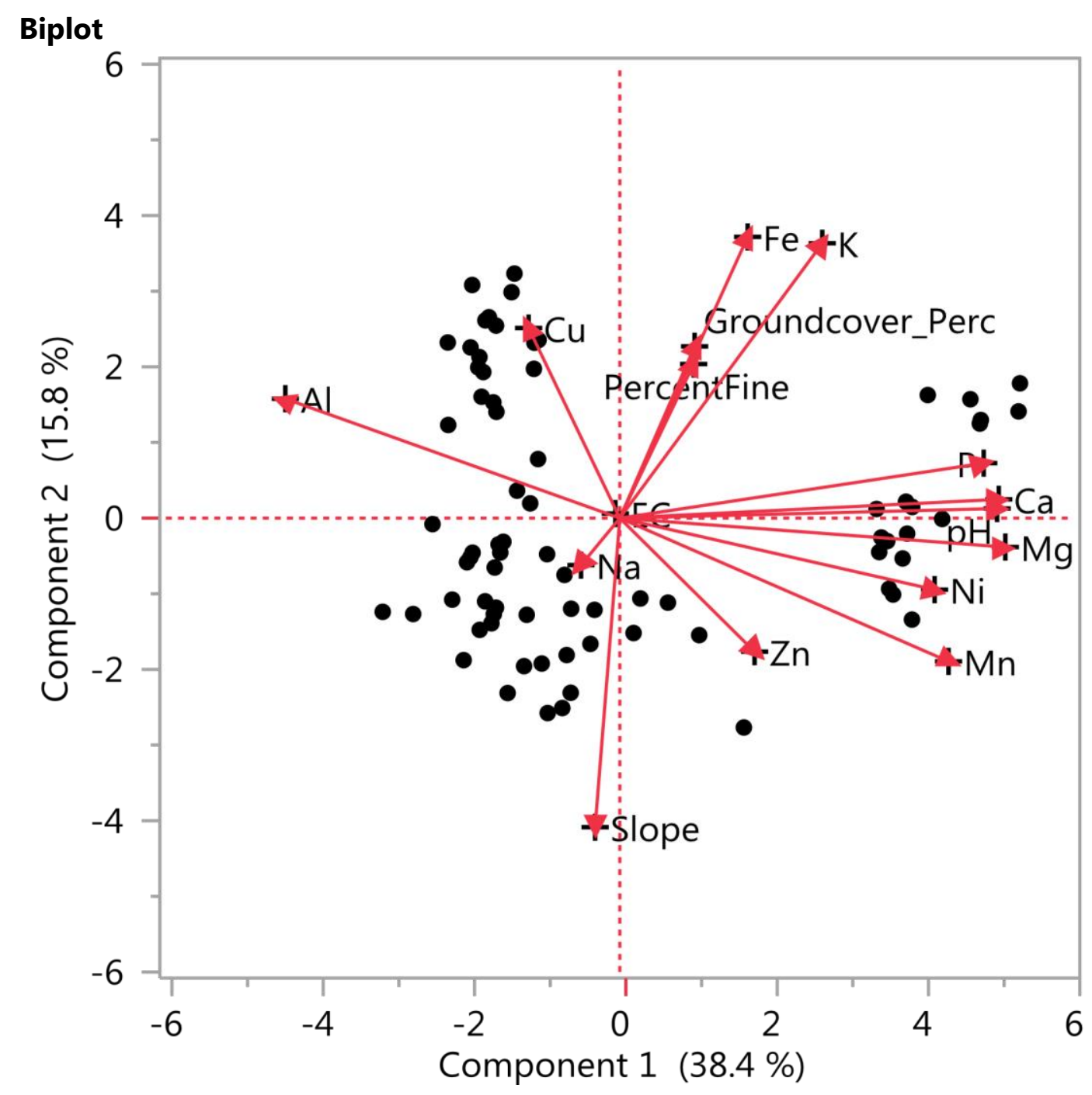

$\checkmark$ Label variables 
PCR Response Normalized_Height Site=HOBET

Whole Model

\section{Effect Summary}

Source LogWorth

PValue

Prin3 By Site

1.467

0.03414

Prin5 By Site 1.236

0.05811

Prin2 By Site

0.695

0.20192

Prin1 By Site

0.182

0.65718

Prin4 By Site

0.074 I ! : : : : $\quad: \quad 0.84318$ 


\section{Actual by Predicted Plot}

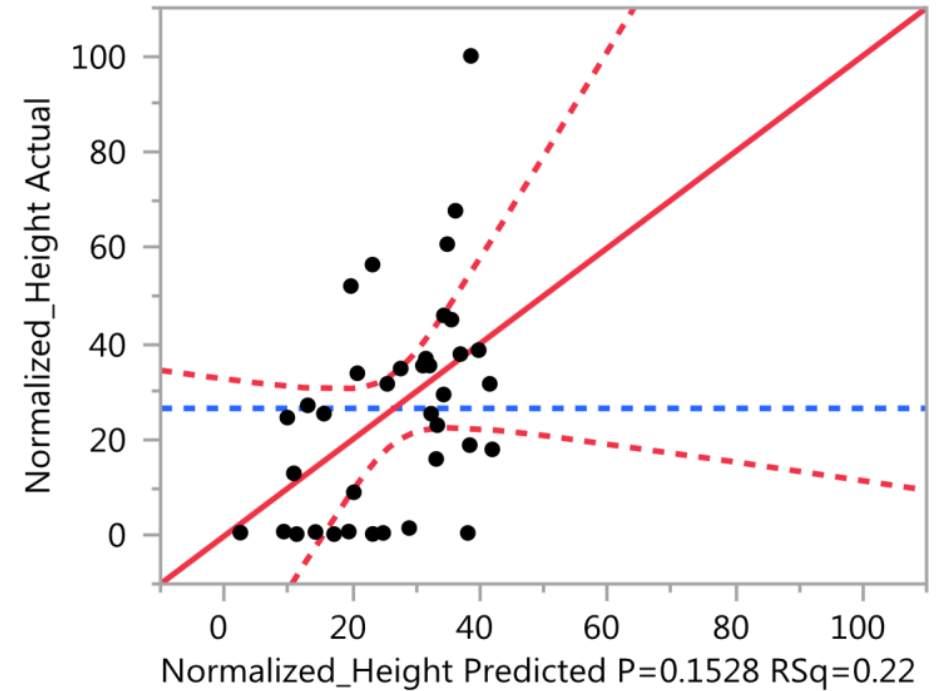

RMSE $=21.673$

\section{Summary of Fit}

$\begin{array}{lr}\text { RSquare } & 0.220056 \\ \text { RSquare Adj } & 0.094259 \\ \text { Root Mean Square Error } & 21.67313 \\ \text { Mean of Response } & 26.55461 \\ \text { Observations (or Sum Wgts) } & 37\end{array}$

\section{Analysis of Variance}

$\begin{array}{lrrrr}\text { Source } & \text { DF } & \begin{array}{r}\text { Sum of } \\ \text { Squares }\end{array} & \text { Mean Square } & \text { F Ratio } \\ \text { Model } & 5 & 4108.422 & 821.684 & 1.7493\end{array}$




\begin{tabular}{lllr|r} 
Error & 31 & 14561.460 & 469.725 & Prob > F \\
\hline C. Total & 36 & 18669.883 & & 0.1528 \\
\hline
\end{tabular}

\section{Parameter Estimates}

$\begin{array}{lrrrr}\text { Term } & \text { Estimate } & \text { Std Error } & \text { t Ratio } & \text { Prob }>|\mathbf{t}| \\ \text { Intercept } & 24.987172 & 3.766276 & 6.63 & <.0001^{*} \\ \text { Prin3 By Site } & 7.0267638 & 3.170391 & 2.22 & 0.0341^{*} \\ \text { Prin4 By Site } & -0.747937 & 3.74913 & -0.20 & 0.8432 \\ \text { Prin5 By Site } & -6.986241 & 3.550533 & -1.97 & 0.0581 \\ \text { Prin1 By Site } & 0.8135694 & 1.81552 & 0.45 & 0.6572 \\ \text { Prin2 By Site } & -4.131659 & 3.16904 & -1.30 & 0.2019\end{array}$

\section{Residual by Predicted Plot}




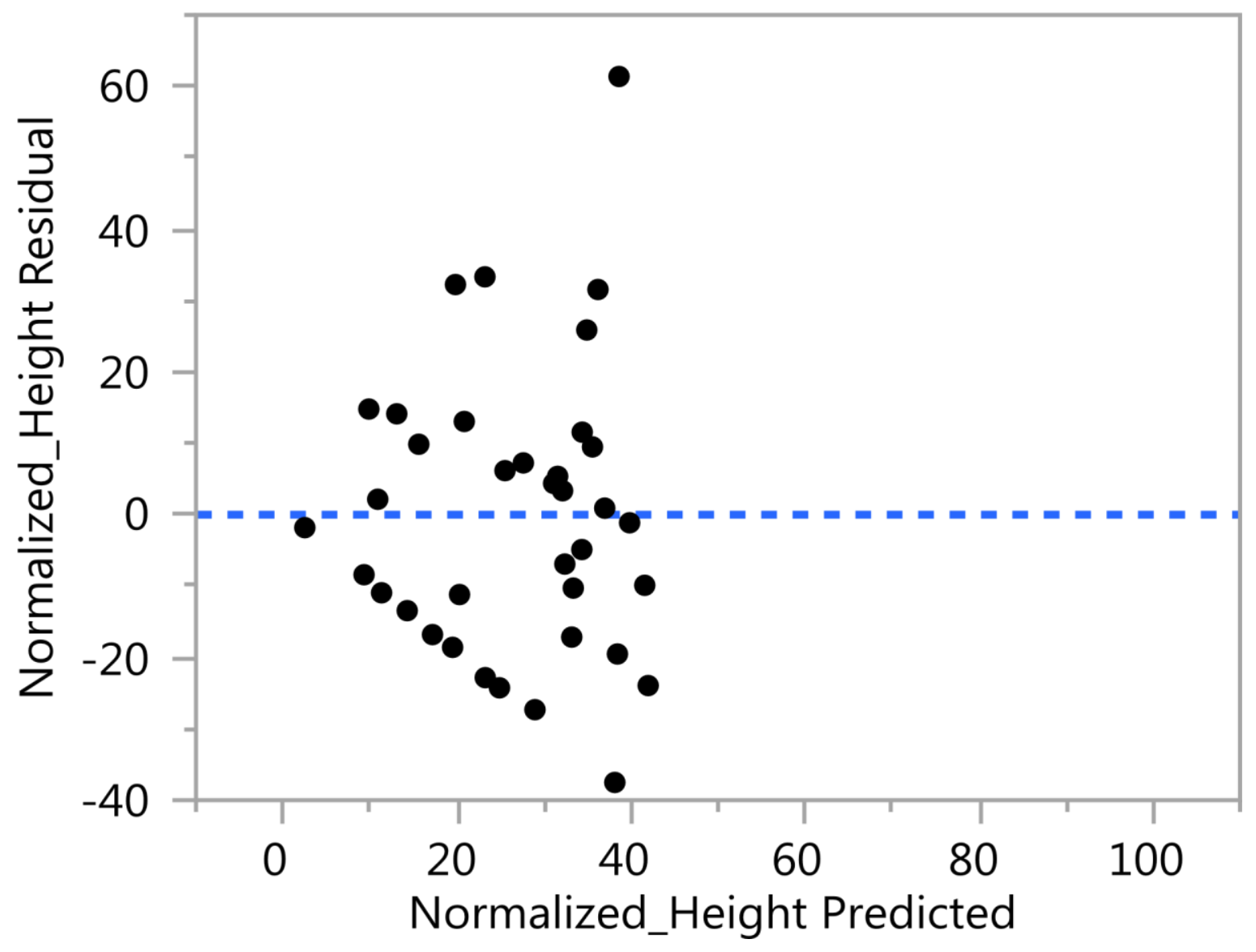


Principal Components: on Correlations Site=ICG

\section{Summary Plots}
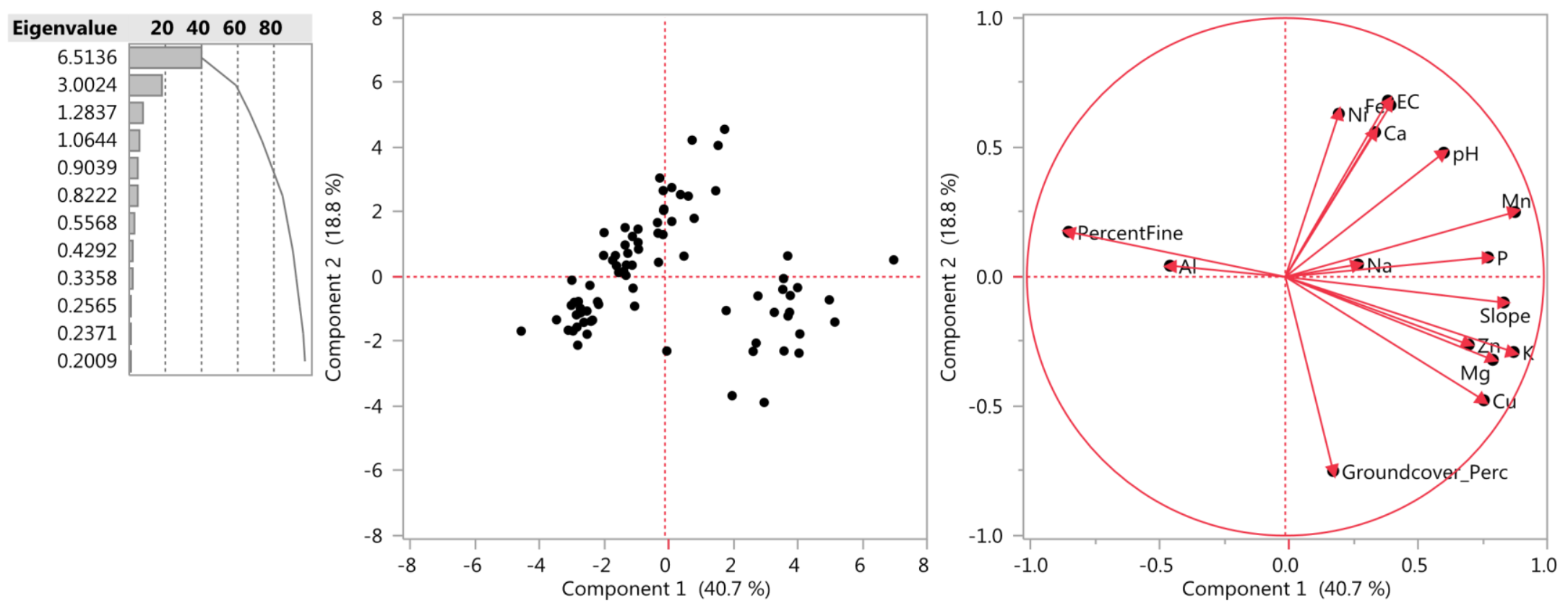

$\checkmark$ Label variables

\section{Eigenvalues}

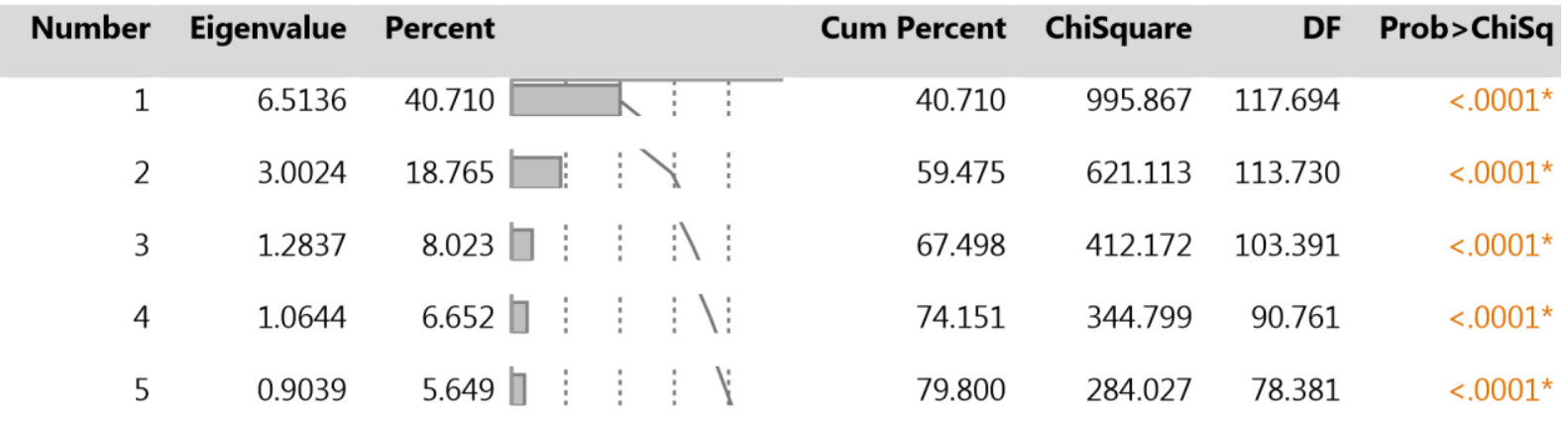




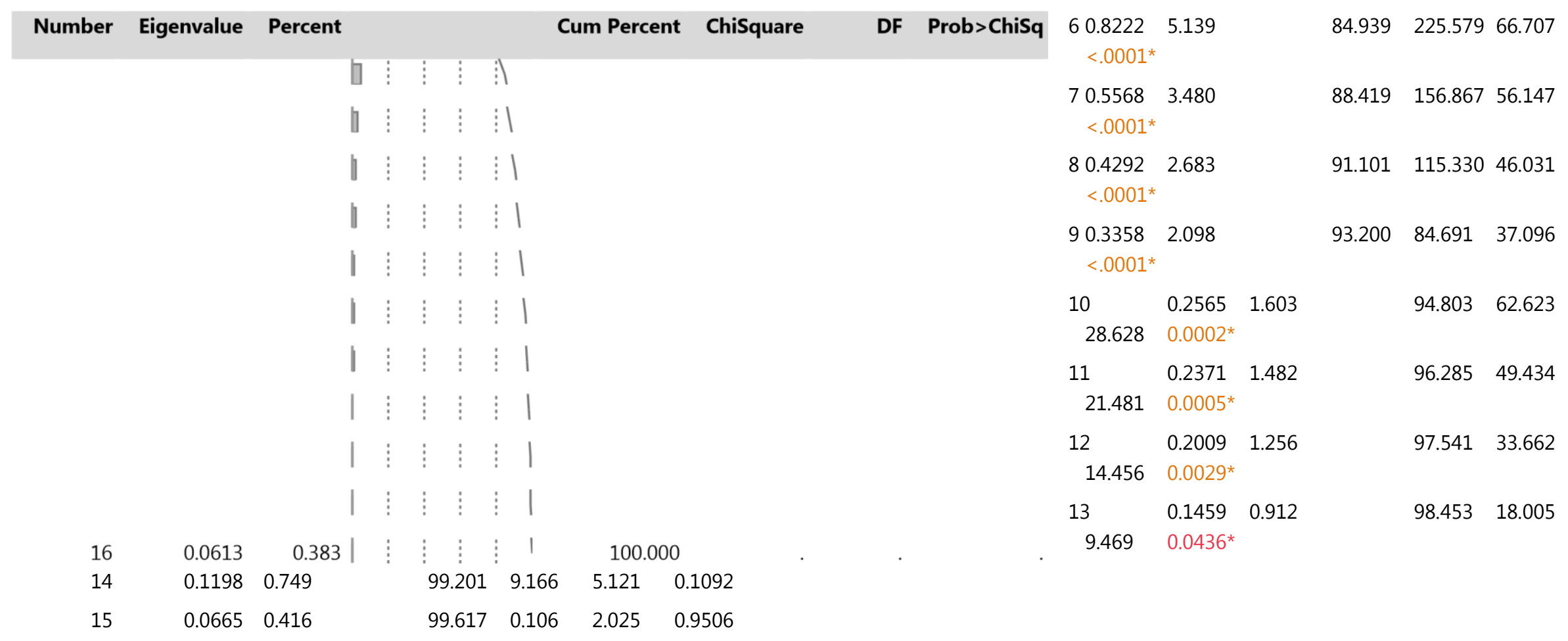

\section{Eigenvectors}

\begin{tabular}{|c|c|c|c|c|c|c|c|c|c|c|c|c|c|c|c|c|}
\hline & Prin1 & Prin2 & Prin3 & Prin4 & Prin5 & Prin6 & Prin7 & Prin8 & Prin9 & Prin10 & Prin11 & Prin12 & Prin13 & Prin14 & Prin15 & Prin16 \\
\hline \multirow[t]{2}{*}{ Slope } & 0.33112 & - & - & - & - & - & - & 0.13642 & - & 0.45485 & 0.17273 & 0.63732 & - & 0.02439 & - & \\
\hline & & 0.0572 & 40.00281 & .03429 & 0.036930. & 265320.2 & 9243 & & 0.22088 & & & & 0.09354 & & 0.02768 & 0.09068 \\
\hline \multirow[t]{2}{*}{ PercentFine } & -( & 0.10039 & - & - & 0.09760 & & 0.29489 & - & 0.29031 & 10.25898 & 0.75028 & 0.04246 & - & 0.01260 & 0.13998 & \\
\hline & 0.32872 & & 0.096990. & 06981 & & 0.00159 & & 0.14529 & & & & & 0.11021 & & & 0.04502 \\
\hline \multirow[t]{2}{*}{$\mathrm{pH}$} & 0.240220 & 0.27689 & - & - & - & - & 0.31767 & - & - & 0.06025 & & & 0.59656 & 0.359570 & 0.17164 & \\
\hline & & & 0.39725 & 0.05713 & 0.128250. & 21586 & & 0.10485 & 0.09153 & & 0.05265 & 0.01350 & & & & 0.00319 \\
\hline
\end{tabular}


$0.037430 .328310 .44062 \quad 0.011660 .156790 .031440 .00085$

\begin{tabular}{|c|c|c|c|c|c|c|c|c|c|c|c|c|c|c|c|c|}
\hline & Prin1 & Prin2 & Prin3 & Prin4 & Prin5 & Prin6 & Prin7 & Prin8 & Prin9 & Prin10 & Prin11 & Prin12 & Prin13 & Prin14 & Prin15 & Prin16 \\
\hline \multirow[t]{2}{*}{$\mathrm{K}$} & 0.34606 & - & 0.11245 & 0.085660 & 0.08298 & - & - & 0.13481 & 0.195330 & 0.07562 & - & - & - & 0.434470 & 0.40069 & - \\
\hline & & 0.16754 & & & & 0.043710 & 0.00152 & & & & 0.02721 & 0.322160 & 0.31892 & & & 0.45364 \\
\hline \multirow[t]{2}{*}{$\mathrm{Ca}$} & 0.136000 & .322640 .2 & 26592 & - & 0.0903 & 380.296000 & 0.489720 & .31670 & -( & 0.04736 & - & 0.14250 & - & $0.02518^{0}$ & 0.134710 & 0.18816 \\
\hline & & & & 0.41604 & & & & & 0.21598 & & 0.12118 & & 0.24418 & & & \\
\hline \multirow[t]{2}{*}{$\mathrm{Mg}$} & 0.31449 & - & & 0.08559 & 0.24315 & & 0.381570. & .150370 .0 & 075530.34 & 4135 & - & - & 0.13038 & - & - & - \\
\hline & & 0.185050 & 0.08340 & & & 0.06587 & & & & & 0.04415 & 0.25820 & & 0.495540 & 0.353940 & 0.20549 \\
\hline \multirow[t]{2}{*}{$\mathrm{Na}$} & 0.110040 & .027600 .3 & 343430.52 & 2321 & - & 0.36110 & 0.19927 & - & & 0.15387 & 70.10243 & 0.051420. & .09687 & & & - \\
\hline & & & & & 0.60654 & & & 0.08072 & 0.04989 & & & & & 0.003630 & 0.021780 & 0.04203 \\
\hline \multirow[t]{2}{*}{$P$} & 0.307160 & .043610 .2 & 224740.04 & 42830.142 & 270 & & 0.15278 & - & & - & & 0.13092 & - & & 0.323830 & 0.07243 \\
\hline & & & & & & 0.23718 & & 0.68346 & 60.011090 & 0.178130 & .06121 & & 0.13106 & 60.32296 & & \\
\hline \multirow[t]{2}{*}{$\mathrm{Al}$} & - & 0.02488 & 0.245520 & 0.544610 & .63002 & & 0.060790 & .09132 & - & & 067750.01 & 16640.051 & 1700.1810 & $30.23031^{0}$ & 0.061200 & 0.16747 \\
\hline & 0.17490 & & & & & 0.02847 & & & 0.27749 & & & & & & & \\
\hline \multirow[t]{2}{*}{$\mathrm{Fe}$} & 0.159350 & 382850.3 & 30429 & - & 0.0952 & 240.17078 & - & 0.03700 & - & 0.10504 & 0.25834 & - & 0.36870 & & 0.17269 & - \\
\hline & & & & 0.20171 & & & 0.47843 & & 0.08799 & & & 0.32848 & & 0.23677 & & 0.10497 \\
\hline \multirow[t]{2}{*}{$\mathrm{Mn}$} & 0.348050 & 144520.1 & 16257 & & 0.06458 & - & - & - & 0.09294 & & 0.20063 & - & - & 0.41054 & - & 0.28688 \\
\hline & & & & 0.07396 & & 0.04527 & 0.056000 & .24861 & & 0.02581 & & 0.187700 & 0.15729 & & 0.62813 & \\
\hline \multirow[t]{2}{*}{$\mathrm{Cu}$} & 0.30095 & - & - & 0.10712 & & 0.13353 & - & 0.18120 & 00.150290 & 0.093000. & .12846 & - & & & 0.327010 & 0.71653 \\
\hline & & 0.275250 & 0.24363 & & 0.02875 & & 0.11196 & & & & & 0.145 & 5290.02290 & 00.09529 & & \\
\hline \multirow[t]{2}{*}{$\mathrm{Ni}$} & 0.081060 & .36384 & - & 0.16997 & 0.245860 & .50633 & - & - & 0.384750 & 0.19601 & - & 0.23508 & - & 0.00288 & & - \\
\hline & & & 0.33184 & & & & 0.159370 & 0.19133 & & & 0.28944 & & 0.09405 & & 0.028020 & 0.08995 \\
\hline \multirow[t]{2}{*}{$\mathrm{Zn}$} & 0.27800 & - & - & 0.0543 & 320.13534 & 0.382940. & .026130 .0 & 01129 & - & - & 0.38985 & 0.11762 & & & & - \\
\hline & & 0.151290 & 0.31882 & & & & & & 0.368500 & 0.51645 & & & 0.0216 & 620.03743 & 30.06081 & 10.23574 \\
\hline Groundcover_P & 0.07249 & - & 0.34499 & - & 0.13816 & 60.20456 & 0.055250. & .001100 .4 & 43758 & - & & 0.33627 & 0.463560 & 13404 & & \\
\hline erc & & 0.43286 & & 0.25971 & & & & & & 0.13530 & 0.00305 & & & & 0.01845 & 50.02925 \\
\hline
\end{tabular}




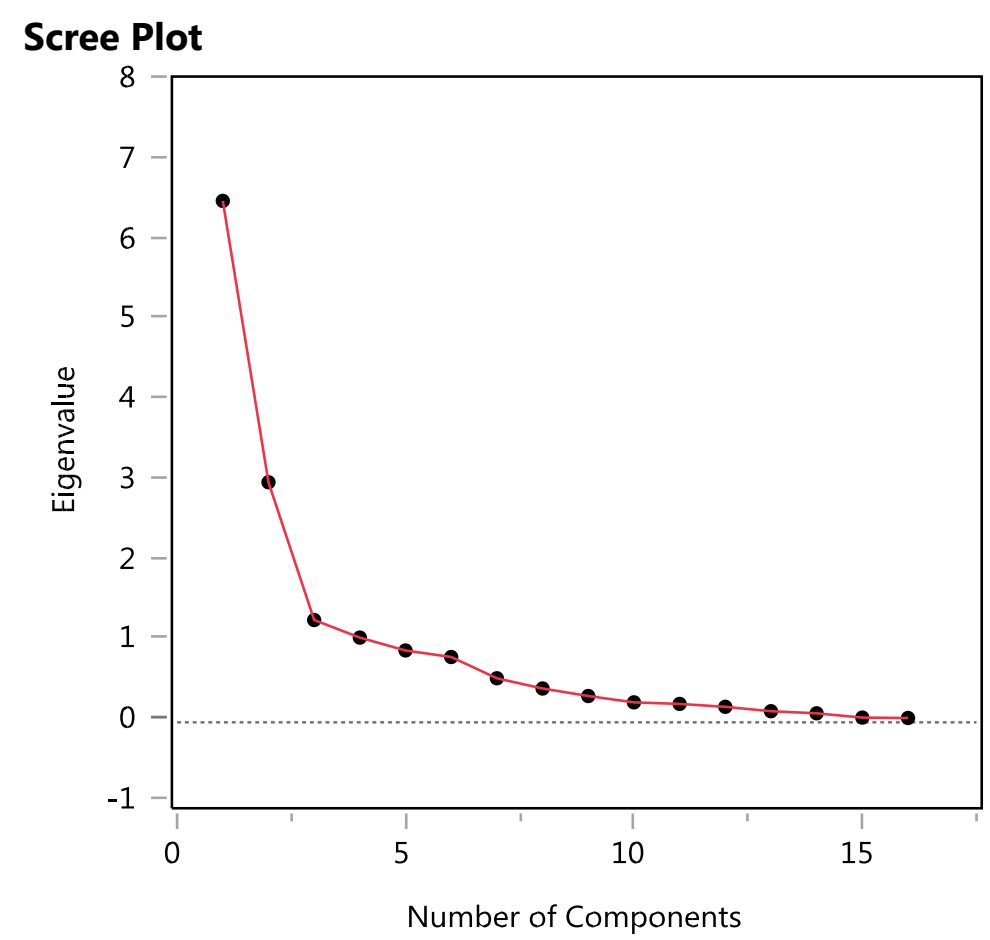

\section{Biplot}




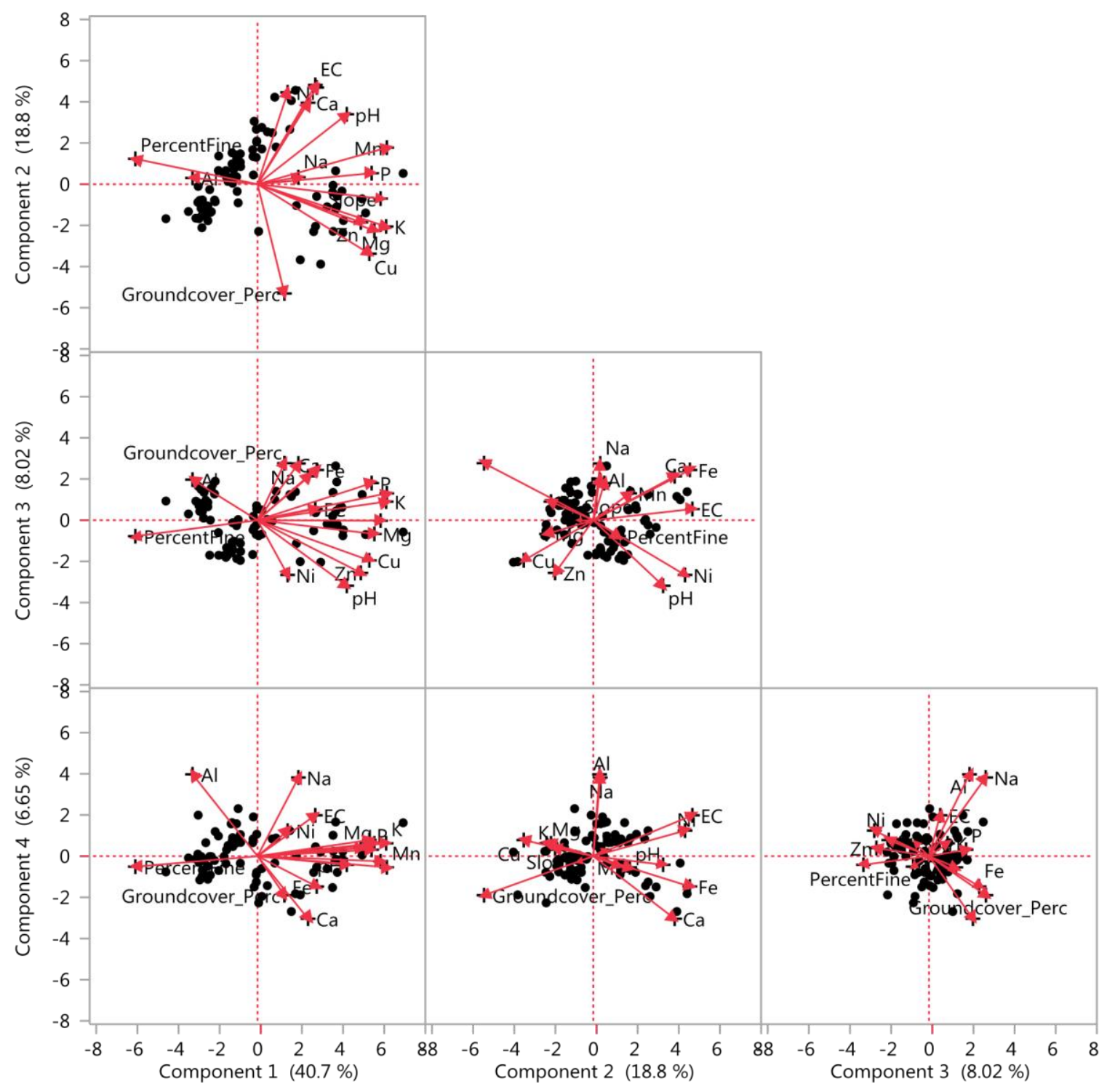

$\square$ Label variables

Principal Components: on Correlations Site=ICG 


\section{Summary Plots}
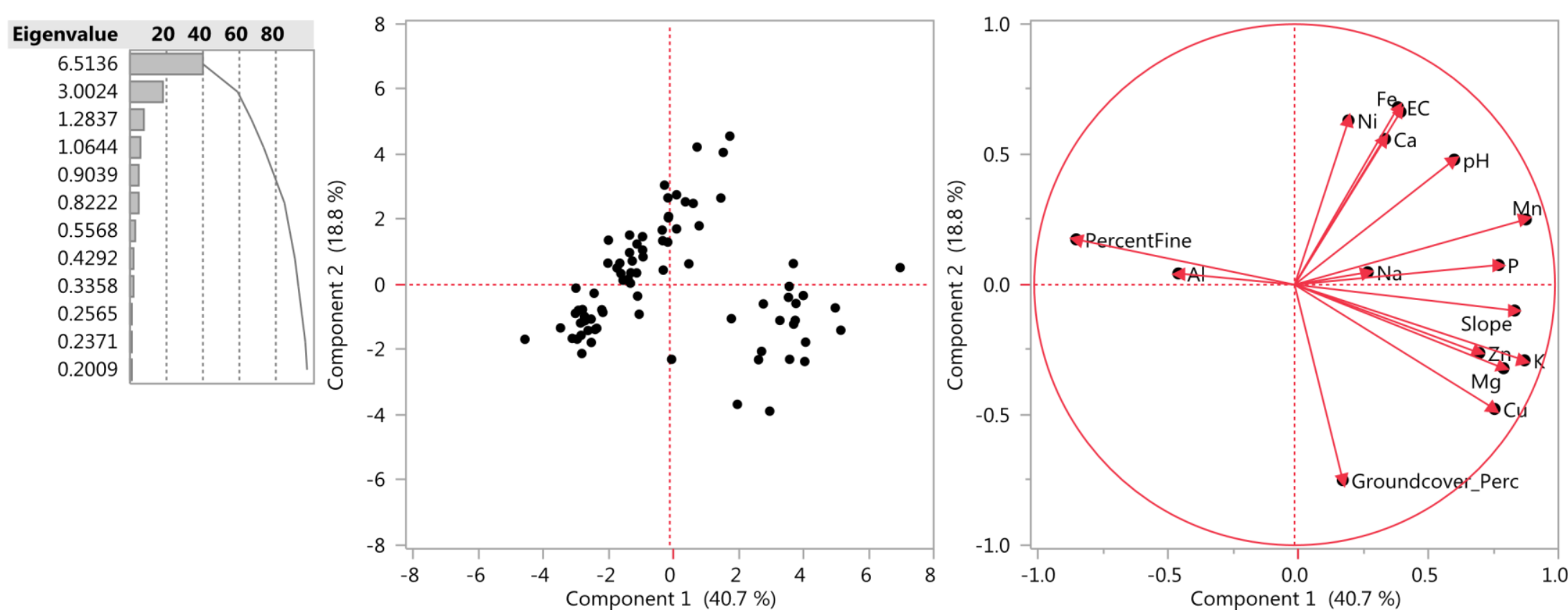

$\checkmark$ Label variables

Biplot 


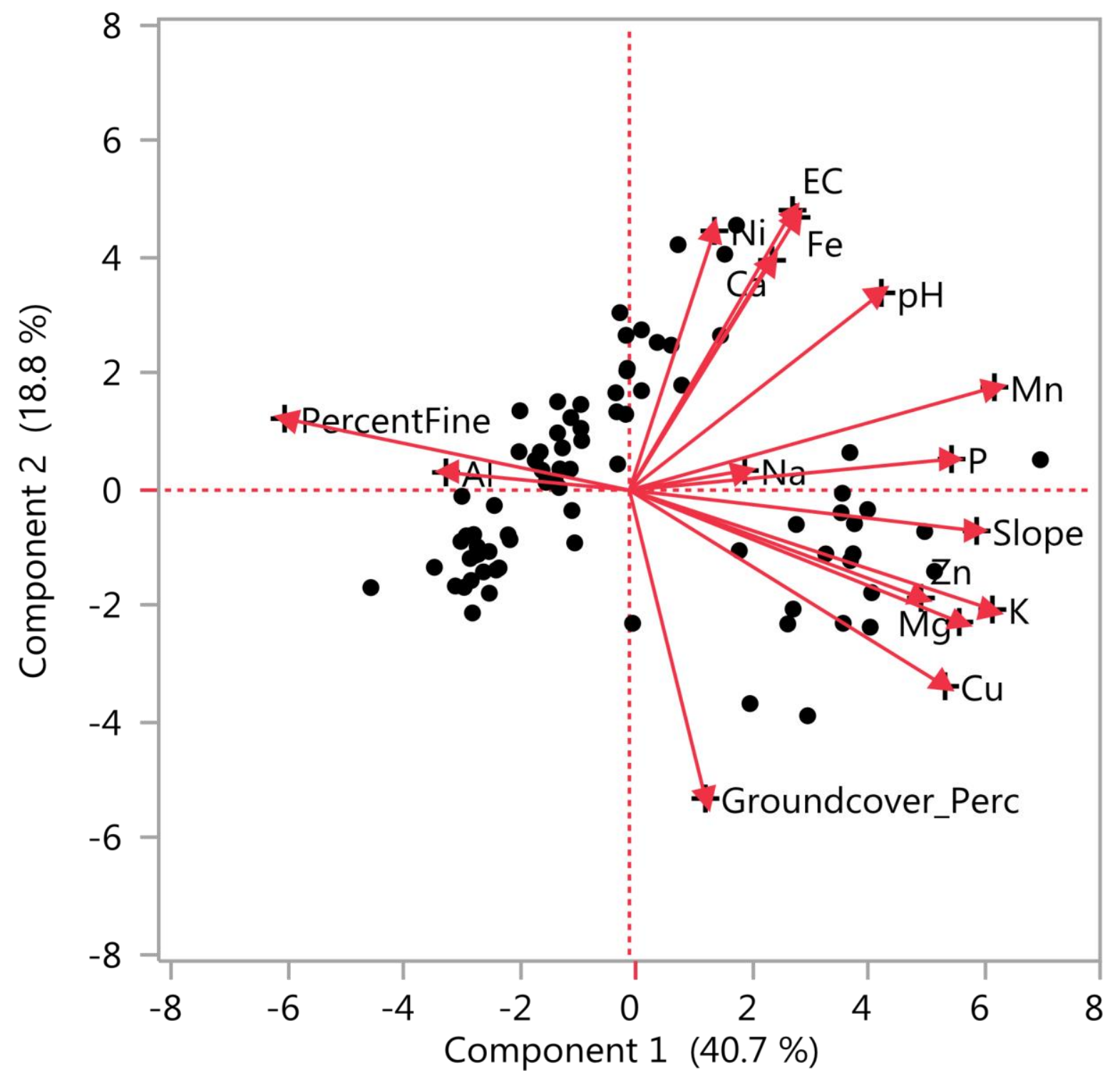

$\square$ Label variables 
PCR Response Normalized_Height Site=ICG

\section{Whole Model}

\section{Effect Summary}

\section{(nfect Summary}

Prin2 By Site

0.868

Prin3 By Site

0.353

Prin5 By Site 0.164

Site $0.082 \quad 0.82761$

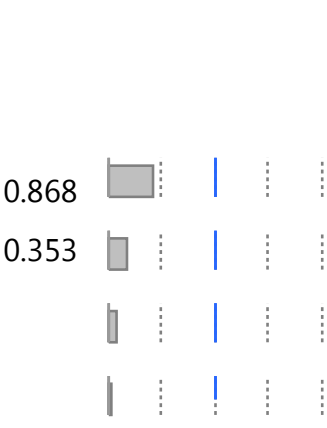

\section{Source}

LogWorth

PValue

Prin1 By Site

2.844

0.00143

0.13551

0.44388

0.68612 Prin4 By

\section{Actual by Predicted Plot}

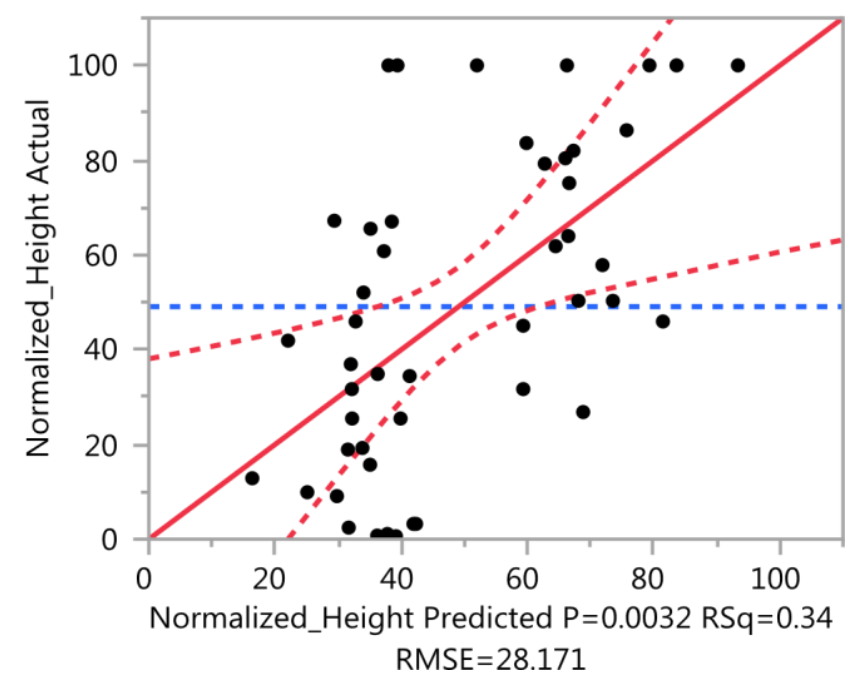

\section{Summary of Fit}

RSquare

0.34269 
Root Mean Square Error

28.17149

Mean of Response

49.08265

Observations (or Sum Wgts)

\section{Analysis of Variance}

\begin{tabular}{lrrrr} 
Source & DF & $\begin{array}{r}\text { Sum of } \\
\text { Squares }\end{array}$ & Mean Square & F Ratio \\
Model & 5 & 16964.220 & 3392.84 & 4.2751 \\
\hline Error & 41 & 32538.944 & 793.63 & Prob > F \\
C. Total & 46 & 49503.164 & & $0.0032^{*}$
\end{tabular}

\section{Parameter Estimates}

$\begin{array}{lrrrr}\text { Term } & \text { Estimate } & \text { Std Error } & \mathbf{t} \text { Ratio } & \text { Prob }>|\mathbf{t}| \\ \text { Intercept } & 43.039731 & 4.824525 & 8.92 & <.0001^{*} \\ \text { Prin3 By Site } & -3.345059 & 4.326648 & -0.77 & 0.4439 \\ \text { Prin4 By Site } & 0.7821756 & 3.568827 & 0.22 & 0.8276 \\ \text { Prin5 By Site } & 1.7762772 & 4.364287 & 0.41 & 0.6861 \\ \text { Prin1 By Site } & 6.0986087 & 1.783498 & 3.42 & 0.0014^{*} \\ \text { Prin2 By Site } & -3.628729 & 2.383087 & -1.52 & 0.1355\end{array}$




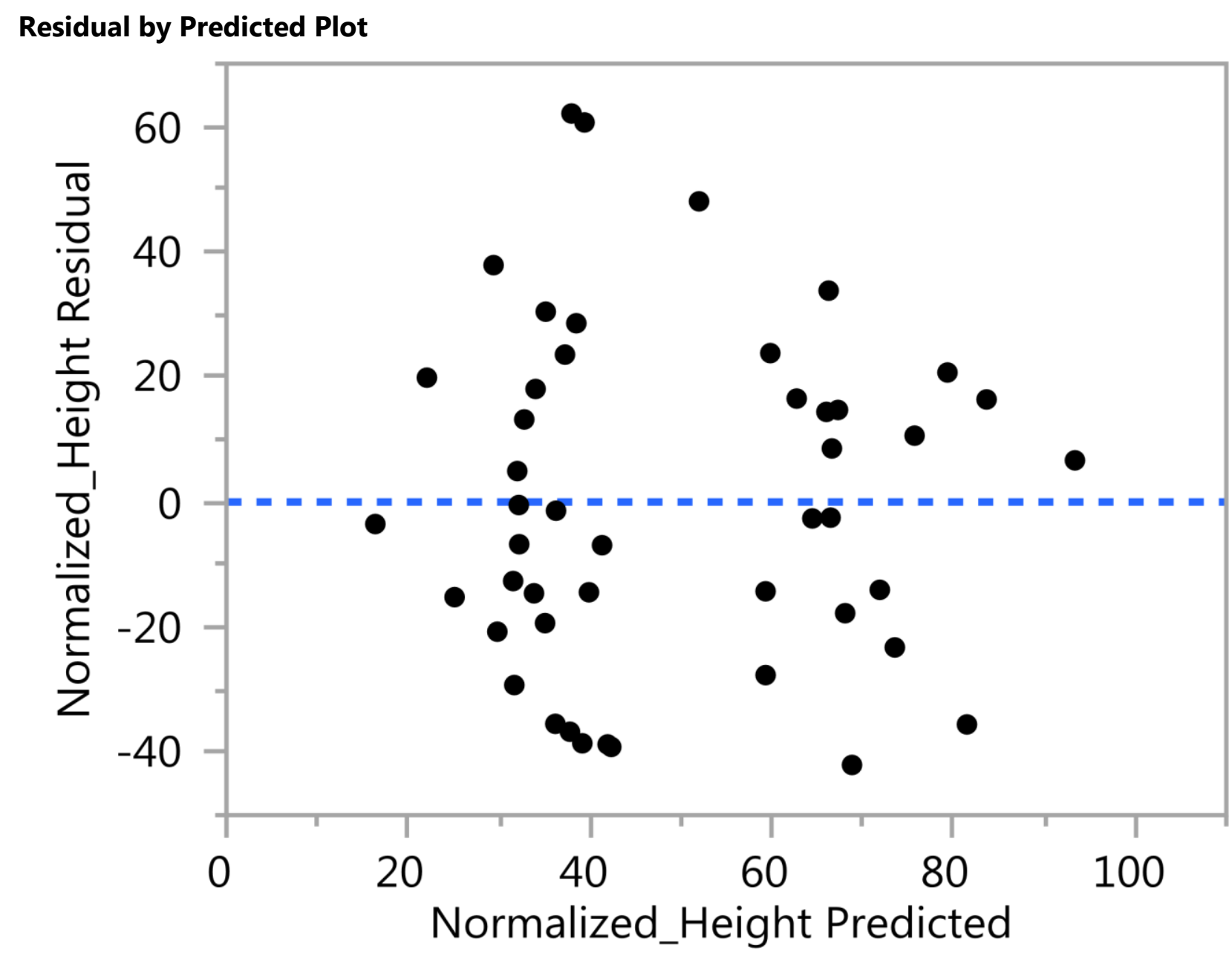

